Andrews University

Digital Commons @ Andrews University

1996

\title{
An Analysis of Growth in the Euro-Asia Division (1985-1995) Leading to a Strategy for Developing Home Churches
}

Galina I. Stele

Andrews University

Follow this and additional works at: https://digitalcommons.andrews.edu/dmin

Part of the Practical Theology Commons

\section{Recommended Citation}

Stele, Galina I., "An Analysis of Growth in the Euro-Asia Division (1985-1995) Leading to a Strategy for Developing Home Churches" (1996). Professional Dissertations DMin. 621.

https://dx.doi.org/10.32597/dmin/621

https://digitalcommons.andrews.edu/dmin/621

This Project Report is brought to you for free and open access by the Graduate Research at Digital Commons @ Andrews University. It has been accepted for inclusion in Professional Dissertations DMin by an authorized administrator of Digital Commons @ Andrews University. For more information, please contact repository@andrews.edu. 


\begin{abstract}
AN ANALYSIS OF GROWTH IN THE EURO-ASIA DIVISION (1985-1995) LEADING TO A STRATEGY FOR DEVELOPING HOME CHURCHES
\end{abstract}

by

Galina I. Stele

Adviser: Bruce L. Bauer 


\title{
ABSTRACT OF GRADUATE STUDENT RESEARCH \\ Dissertation
}

\author{
Andrews University \\ Seventh-day Adventist Theological Seminary
}

Title: AN ANALYSIS OF GROWTH IN THE EURO-ASIA DIVISION (1985-1995) LEADING TO A STRATEGY FOR DEVELOPING HOME CHURCHES

Name of researcher: Galina $I$. Stele

Name and degree of faculty adviser: Bruce L. Bauer, D.Miss.

Date completed: June 1996

\section{Problem}

The Euro-Asia Division is experiencing many challenges due to rapid growth in membership during the decade of 1985-1995. This study shows some of the main needs of the Division and suggests a strategy for developing home churches in order to meet the present challenges.

\section{Method}

A church-growth analysis of the Euro-Asia Division was conducted for the years 1985-1995 to discover problems and challenges. The advantages that a home-church approach would bring in solving many of the challenges is discussed. 
Guiding principles for organizing house churches and training home-church leaders are suggested.

\section{Results}

The church-growth analysis showed that the main challenges in the Euro-Asia Division are apostasy of new members, inadequate number of pastors, inadequate number of church buildings, and multitudes of unreached people. Home churches are effective means for assimilating new members, for providing pastoral care and adequate worship environment, and for reaching unreached people. It was suggestion that small groups be started on the basis of common interests but gradually move to the geographical groups. It was concluded that all four components of a home-church meeting (nurture, worship, community, and mission) should be included in each meeting. The role of the pastor and the involvement of the congregation was shown as vital for the success of house churches. The type of small group system (the appendage system, the incorporated system, and the integrated system) that is developed largely depends on who starts the house-church ministry, with lay leaders, assigned leaders, and pastoral leaders all impacting in different ways. To achieve 90 percent involvement of the congregation in home churches and successful outreach through small groups, the integrated system was shown to be best. A suggested training schedule, method of training, and principles for the selection of the home-church leaders are presented. 


\section{Conclusions}

The integrated system for home churches is suggested in order to meet the challenges in the Euro-Asia Division. Each pastor in the Division should provide dynamic leadership in the development of a house-church ministry and should be personally involved in the training of the group leaders. 


\author{
Andrews University \\ Seventh-day Adventist Theological Seminary
}

AN ANALYSIS OF GROWTH IN THE EURO-ASIA DIVISION (1985-1995) LEADING TO A STRATEGY FOR DEVELOPING HOME CHURCHES

\author{
A Dissertation \\ Presented in Partial Fulfillment \\ of the Requirements for the Degree \\ Doctor of Ministry
}

by

Galina I. Stele

June 1996 


\title{
AN ANALYSIS OF GROWTH IN THE EURO-ASIA DIVISION (1985-1995) LEADING TO A STRATEGY FOR DEVELOPING HOME CHURCHES
}

\author{
A dissertation \\ presented in partial fulfillment \\ of the requirements for the degree \\ Doctor of Ministry
}

by

Galina I. Stele

APPROVAL BY THE COMMITTEE:
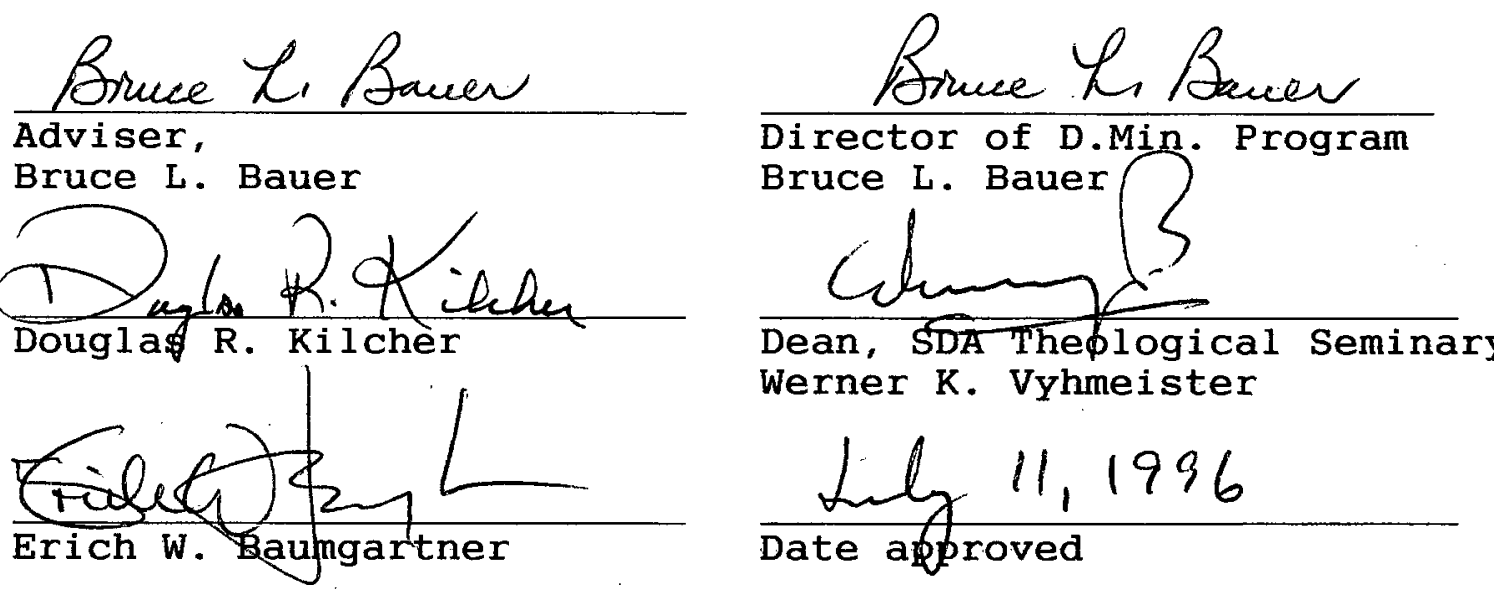

To my beloved husband Artur A. Stele and wonderful son Alexander 
LIST OF ILLUSTRATIONS. . . . . . . . . . . . . vii

LIST OF TABLES . . . . . . . . . . . . . . ix

INTRODUCTION . . . . . . . . . . . . . . . . 1

Purpose ..................... . 1

Justification .................... . . . . . . 1

Definition of Terms . . . . . . . . . . . . . . 5

Methodology . . . . . . . . . . . . . . . 6

Limitations . . . . . . . . . . . . . . . . 8

Chapter

1. BACKGROUND OF THE EURO-ASIA DIVISION AND

AN ANALYSIS OF CHURCH GROWTH FROM 1985

то 1995 . . . . . . . . . . . . . . . . . 10

Background of the SDA church in the

Euro-Asia Division. . . . . . . . . . . 10

The Euro-Asia Division Name, Location, and Some Specific Characteristics. . 11

Origin of the SDA church in the

Territory of the Euro-Asia

Division. . . . . . . . . . 13

Brief Review of Subsequent

Growth . . . . . . . . . . . 19

Church Growth in the Euro-Asia Division

during 1985-1995. . . . . . . . . . . 28

1985-1995--a Decade of New

Opportunities . . . . . . . . . . 28

A Period of Transition and

New Opportunities: 1985-1990. . . 29

A Period of Public Evangelism:

1991-1995 .. . . . . . . . . . 34

An Analysis of the Increase of the

Church Membership in the Euro-Asia Division during 1985-1995... .

Three Sources of the Decrease of

Membership . . . . . . . . . 59

Infrastructure Weaknesses in the

Euro-Asia Division: Inadequate Number of Pastors and Church

Buildings. . . . . . . . 
Comparative Analysis of Church Growth

in the Euro-Asia Division Unions and

Summary.

Attached Fields in 1991-1995. . . . 77

2. HOME CHURCHES: A POSSIBLE SOLUTION. . . . . 104

Challenge of the Apostasy of New Members . 104

The Reasons for Apostasy as Seen by the

Church in the Euro-Asia Division . . 104

Home Churches as a Possible Solution

to the Needs of New Converts... . 108

Home Churches and the Needs in
Relation to God... . . . . 110

Home Churches and the Needs in
Relation to People. . . . . . 119

Challenge of the Lack of Pastors . . . . . 127

Challenge of the Lack of Church

Buildings . . . . . . . . . . . . . 131

Challenge to Reach the Unreached . . . . . 135

House Churches as an Effective Means

for Reaching Primary Circles of

Believers . . . . . . . . . 135

House Churches as an Effective Means for

Reaching and Assimilating Followers

of Other Non-Christian

Religions........... 140

House Churches as an Effective Means

for Reaching Urban Populations . . . 144

Summary. . . . . . . . . . . . . . 150

3. GUIDING PRINCIPLES FOR SETTING UP

HOUSE CHURCHES. - . . . . . . . . . . . 153

Formation of Home Churches . . . . . . 153

Homogeneous vs. Heterogeneous . . . . 154

Voluntarily Choice of a Group . . . . 156

Assignment to the Group . . . . . . . 157

Random Assignment . . . . . . . . . 159

Suggested Method. . . . . . . . . 160

The Role of the Pastor . . . . . . . . . 162

The Role of the Congregation . . . . . . . 164

The Size of a Home Church. . . . . . . . . 168

Components of Home-Church Meetings . . . 171

Nurture . . . . . . . . . . . . 172

Worship . . . . . . . . . . . . 175

Community . . . . . . . . . . . . . 177

Mission . . . . . . . . . . . . . 178

SummarY. . . . . . . . . . . . . . . . 181 
4. THE SELECTION AND TRAINING OF HOME-CHURCH LEADERS • • • • . . • • • • • • • • • • • 184

The Function and Role of the Trainer . . 184

Who Should Be the Trainer . . . . . . 184

The Approach to Leadership. . . . . . 193

The Training Method . . . . . . . . 202

Training Schedule and Suggested

Structure . . . . . . . . . . 207

Training Schedule . . . . . . . . 207

Planning Stage... . . . . . . . 207

Developmental Stage. ... . . . . 208

Launching Stage. . . . . . . . . 210

Outreach and Second-Term Training

Stage . . . . . . . . . . 211

Multiplication, Evaluation, and

Celebration Stage.. . . . . . 213

Suggested Structure . . . . . . . . 215

Selection of Home-Church Leaders . . . . 218

The Method of Selection . . . . . . . 219

Qualities Needed for a Home-Church

Leader . . . . . . . . . . . . 221

Relationship to God. . . . . . . 221

Personal Life. . . . . . . . . . 227

Relationships with Others. . . . . 232

Summary. • • • • • • • . . . • • . 233

CONCLUSIONS AND RECOMMENDATIONS. . . . . . . . . 236

Appendix

1. OUTLINE FOR A TWELVE-WEEK TRAINING PROGRAM. - 245

2. QUESTIONNAIRE . . . . . . . . . . . . . . 265

3. SUMMARY OF DATA FOR THE EURO-ASIA DIVISION, 1985-1995 • • • • • • • • • • • . . . 267

BIBLIOGRAPHY . . . . . . . . . . . . . . . 268

VITA . . . . . . . . . . . . . . . . . . . 284 


\section{LIST OF ILLUSTRATIONS}

1. Growth of the SDA Church Membership in the Euro-Asia Division. . . . . . . . . . . . . .

2. Accessions in the Euro-Asia Division during the 1985-1995 Period. . . . . . . . . . .

3. The Percentage of Accessions of the Church Membership during 1985-1995 . . . . . . . . 52

4. Annual Growth Rates in 1985-1995 . . . . . . . . 55

5. Three Perspectives on the Decadal Growth Rate. . . 57

6. Death and Transfers Out. . . . . . . . . . . 61

7. Apostasy and Accessions during the 1985-1995 Period. . . . . . . . . . . . . . . 64

8. Church Membership, Accessions, and Apostasy. . . 64

9. Apostasies as a Percentage of Accessions and Church Membership . . . . . . . . . . . 65

10. Percentage of 1991-1995 Converts in the Total Membership of 1995............... 67

11. Net Gains and Their Proportion to Accessions . . . 68

12. A Comparison between Numbers of Congregations and Pastors during 1986-1995. . . . . . . . . . 70

13. Number of Congregations without Church Buildings in the 1990-1995 Period . . . . . . . . . . 75

14. Number of Congregations and Church Buildings in the 1990-1995 Period. . . . . . . . . . .

15. The Percentage of the Population in the Unions and Attached Fields of the Euro-Asia Division . .

16. Seventh-day Adventists' Presence as Compared to the Population of the Euro-Asia Division. . . 
17. Membership Growth in the Different Parts of the Euro-Asia Division during 1991-1995. . . . . . 83

18. AGR for Five Parts of the Division during the 1991-1995 Period... . . . . . . . . 86

19. Accessions and Apostasies in Five Parts of the Division in the 1991-1995 Period. . . . . . 90

20. Number of Churches without Church Buildings in the Different Parts of the Division in 1995. . . 92

21. Number of Congregations and Pastors in the Different Parts of the Division in 1995. . . . . 93

22. Decadal Growth Rate of the Unions and Attached Fields of the Division . . . . . . . . . . 95

23. Percentage of Adventists as Compared to the Population of the Unions and Attached Fields of the Division. . . . . . . . . . . . 97 
1. Church Membership in the Euro-Asia Division in the 1985-1995 Period. . . .........

2. Accessions and Their Percentage for the Church Membership in 1985-1995. . . . . . . . . .

3. Annual Growth Rates in 1985-1995. . . . . . . . . 54

4. Death and Transfers Out . . . . . . . . . . 60

5. Apostasy and Its Percentage of the Accessions and of the Total Membership. . . . . . . 63

6. Net Gains and Net Gains as a Percentage of Accessions. . . . . . . . . . . . . . . 68

7. Ordained and Licensed Ministers. . . . . . . . 71

8. Number of Congregations with and without Church

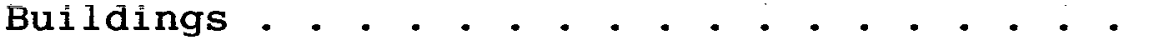

9. The Percentage of the Population in the Euro-Asia Division Unions and Attached Fields . . . . .

10. Comparative Membership Growth in the Different Parts of the Division during 1991-1995. . . . .

11. AGR for the Five Parts of the Euro-Asia Division during 1991-1995 (in Percentages) . . . . . .

12. Total Accessions and Apostasies for the 1991-1995 Period and Apostasies as a Percentage of Total Accessions and Church Membership in 1995

13. Number of Total Congregations and Those without Church Buildings, and Number of Pastors and the Ratio of Members per Minister in 1995

14. DecadaI Growth Rate for the 1985-1995 Period (in Percentages) 
15. The Percentage of Adventists as Compared to the Population of the Unions/Missions and the Ratio of Non-Adventists per SDA Member in 1995 . . . . . . . . . . . . . . . 96

16. Reasons Why New Members Apostatize $(\underline{N}=121)$. . . 106

17. Reasons Why Members Become Missing ( $\underline{N}=121)$. . . 107 
INTRODUCTION

\section{Purpose}

The purpose of this dissertation is to investigate the challenges the Euro-Asia Division is presently facing and to suggest a strategy for organizing home churches in order to meet these challenges.

\section{Justification}

Home churches have a long history in the former Soviet Union. Prohibition of religious gatherings and official church buildings during certain periods led to illegal meetings of believers in private houses. However, there was a striking difference between the worship in these home gatherings and the meetings of the modern small groups. Although gathered at a private home, the believers followed the format of service used in a church building. These home churches were seen by them as a disadvantage created by the strict communist regime. For long decades, Adventists dreamed for better times of religious freedom and the opportunity to abandon this home-church model.

The first attempts to introduce to the ministers of this Division a home-church approach as an excellent setting 
for reaching and nurturing secular people were made in the 1980s. At that time, public evangelism was still prohibited, although many of the congregations had already conducted their services in the church buildings. Seminars were conducted, and in some places this approach took root. The decade of 1985-1995 (especially its second part) brought tremendous changes to the Adventist church in the former Soviet Union. Collapse of the communist ideology and disintegration of the U.S.S.R. opened new opportunities for religious freedom and public proclamation of the gospel. Evangelistic crusades conducted by foreign and local Adventist ministers attracted thousands of people. These new opportunities refocused the evangelistic efforts of ministers and lay members from personal to public evangelism. The church membership more than tripled during this decade.

However, the SDA church was not prepared to meet the challenges this growth brought. As a result, many congregations gathered in public halls, not all of them had a minister, and many of those newly converted left the church. The need for a specific follow-up program, that could prevent apostasy, became obvious.

At that time a house-church approach for effective assimilation and discipleship of new members was suggested to the Division. Pastors and lay members from different 
parts of the Division went through the seminars on small groups and many home churches were organized. However, many of these home churches had a short life. One primary reason was the careless selection of the group leaders. The concept that anybody can be a home-church leader was widespread. As a result, many of the recently converted members, who were excited about smal1-group ministry, became home-church leaders. Another reason was that many of the home-church leaders lacked the knowledge of how to keep the groups operating once they were started. Observation indicates that, by and large, the home churches in the EuroAsia Division represented the appendage or the incorporated systems, 1 and that in many places there was a lack of wel1organized supervision. Although those groups that happened to have devoted leaders showed good progress, many of the pastors or chosen coordinators did not have enough knowledge to coordinate this new work. The consequences of all these factors were very destructive: strange teachings were introduced, some groups were even led to other denominations, in some places almost all the newly started groups died out, and resentment to this approach began to grow.

Nevertheless, new home churches have been forming for several years in the Division. In spite of all the above

\footnotetext{
${ }^{1}$ For three kinds of group systems see chapter 4 .
} 
complications, there are still many people in the Division willing to use a home-church approach in their

congregations. When asked in the fall of 1995, "Can the house churches (in your opinion) help solve the problem with apostatized and missing members?" 96 of 121 respondents answered "yes." 1 To another question, "What are the primary reasons for the breakdown of home churches in the Euro-Asia Division?" the following factors were specified: inadequate training of home-church leaders (71\%); inadequate information of how to start a home-church ministry (48\%); haphazard meetings with home-church leaders (45\%); and confusion of the purpose for home churches (43을. About one third of the participants also pointed to the disunity of the home churches, inadequate involvement of pastors, and lack of developed lessons for home-church meetings as reasons contributing to the failure of home-church ministry. Thus, an investigation of the major challenges of the Euro-Asia Division and the potential of home churches can be very helpful for those who hesitate to implement it.

1 This questionnaire consisted of two major sections: one dealt with the reasons for apostasy of new members, the other focused on home churches. See chapter 2 and appendix 2. Six people from these 96 answered affirmatively but with some reservations: "Yes, but in large congregations"; "Yes, but it is not a panacea"; "Yes, but a training program is needed"; "Yes, if there are wise people leading to the unity in Christ"; "Yes, if they are well organized." However, none of those questioned gave a negative answer: 13 people did not give any answer at all; 9 people answered

"partially"; and 3 people answered "maybe." 
Moreover, there is an obvious need for a more thorough strategy for organizing home churches in this Division. To secure good results in the future, more information on the selection and training of leaders and the role of the pastor is needed. Although there are a lot of good materials on small-group ministry in the English language, this dissertation suggests a specific strategy for organizing home churches in the different context of the Euro-Asia Division. The primary purpose of this strategy is to adapt a small-group approach to the already-existing model of home churches in this Division and to fill the informational gap on some specific issues of this approach in the Russian language.

\section{Definition of Terms}

The major terms frequently used in this dissertation are a "house church" (or a "home church"), a "house-church approach," a "house-church ministry," and a "house-church leader."

The term "home church" as used in this dissertation is similar to the American concept of a small group or a home cell. Thus, a home church is a small group of people (about twelve) that gathers regularly at a private home for worship, nurture, fellowship, and mission. Members of the home church belong to the larger body of believers and participate in the corporate Sabbath service as well. Thus, 
this term is not identical with the concept of a "home church" as an autonomous small church that is gathering at a private home. The terms "home church" and "small group" are used interchangeably in this work. However, preference is given to a "house church" since this term has already become an equivalent for a small group in the Russian language.

The term "house-church approach" stands for an approach that implements small groups in the churches.

The expression "house-church ministry" is also often used in this dissertation. It reflects the idea of an organized network of home churches in a congregation.

The term "house-church leader" stands for a person responsible for a home church and not for a leader in one of the house-church meetings. In some literature this person is called a home-cell leader, or a lay pastor.

\section{Methodology}

This dissertation does not follow the common procedure of building a biblical foundation for the suggested strategy of house churches since it has been done in my master's thesis. ${ }^{1}$ To achieve the purpose stated above, the following methodology was chosen:

First, chapter 1 presents a brief review of the background of the Adventist church in the Euro-Asia Division

${ }^{1}$ Galina I. Stele, "New Testament Home Churches as a Solution to Some of the Main Challenges in the Euro-Asia Division" (M.A. thesis, Andrews University, 1993). 
and an analysis of church growth between 1985-1995. The background of the Euro-Asia Division is presented in order to place the decade under investigation within its historic framework and to show the uniqueness of the events the Division is presently experiencing. The analysis of the church growth includes a general analysis of growth of the whole Division, and a comparative analysis of church growth in the Union Conferences and attached fields of the Division as well. The purpose of these two types of analysis is to investigate whether the Division as a whole and all of its separate parts are facing the same challenges. In addition, a comparative analysis should give a more accurate picture of the needs of every part of the Division.

Second, after the challenges are investigated, chaper 2 suggests a home-church approach as a possible solution. An evaluation is made as to whether home churches can become a good means to meet the needs of secular people and thus to prevent apostasy of new members, whether they can answer the challenge of inadequate numbers of pastors and church buildings, and whether this home-church approach can be effective in reaching unreached people.

Third, the guiding principles for organizing home churches are presented in chapter 3. Different approaches to the enrollment in groups, the role of the pastor and a 
congregation, the size of a home church, and necessary components of a small-group meeting are investigated.

Chapter 4 , focuses upon the training and selection of home-church leaders. Options of who will be the trainer of the group leaders, and the approach to the leadership and to the training method are studied. A training schedule and suggested structure are promoted, and the principles for the selection of the home-church leaders are discussed. Finally, conclusions and recommendations are presented. Outlines for the twelve-week training program are supplied in the appendix.

\section{Limitations}

The dissertation has some limitations. Neither the background nor an analysis of church growth in the Euro-Asia Division in the 1985-1995 period is presented in complete detail. Only those facts that are helpful in presenting a general picture and point to the present challenges of the Division are discussed. It is also not the purpose of this work to stress every possible way that home churches can meet the present challenges. Those factors that crucially answer the problems of this Division are presented. When guiding principles for starting a home church are discussed, the focus is on those that are not well known or followed in the Division. It is also not the purpose of this dissertation to give exhaustive information on the training 
and selection of the group leaders since this issue can be an independent work by itself. Weak areas of the homechurch ministry in the Euro-Asia Division are addressed and issues necessary for developing the suggested support system are focused on. 


\section{CHAPTER 1}

\section{BACKGROUND OF THE EURO-ASIA DIVISION AND AN ANALYSIS OF CHURCH GROWTH FROM 1985 TO 1995}

This chapter briefly surveys the background of the Adventist church in the Euro-Asia Division and presents a general analysis of church growth from 1985 to 1995.1 The main purpose of this chapter is to answer these questions: What is the Euro-Asia Division? How did the Adventist message come to this part of the world? How did the church grow? What kind of changes did the 1985-1995 decade bring? What parts of the Division are the most challenging at the present time?

\section{Background of the SDA Church in the Euro-Asia Division}

This section introduces the Euro-Asia Division and gives a short history and origin of the SDA church in this territory. The main points of the development and growth of the church through 1985 are also highlighted.

$1_{\text {This chapter }}$ does not present an exhaustive history of the SDA church in the Euro-Asia Division. Nevertheless, selected examples provide enough information to understand its background. 
The Euro-Asia Division Name, Location, and Some Specific Characteristics

The Euro-Asia Division is a part of the worldwide Seventh-day Adventist Church. Its first official name was the Union of Soviet Socialist Republics Division at the time of its formation at the fifty-fifth General Conference session in July 1990. 1 It had five Union Conferences then-the Baltic, Moldavia, Russian Federated, Southern, and Ukrainian--which were cordially accepted "into the world sisterhood of unions of the Seventh-day Adventist Church." 2 The Division was renamed the Euro-Asia Division in $1991^{3}$ to more closely reflect its geographical location during that time of political instability and uncertainty after the breakup of the Soviet Union.

Thus, geographically, the Euro-Asia Division unites Adventists of the European and Asian parts of the former U.S.S.R. The only change came about when believers from the former Baltic republics chose to belong to the TransEuropean Division. On January 1, 1994,4 the Baltic

1"Session Actions: Union of Soviet Socialist Republics Division of the General Conference of Seventh-day Adventists," Adventist Review, July 9, 1990, 10.

2 Ibid.

${ }^{3}$ Shirley Burton, "Report from Perth--II, " Adventist Review, November 7, 1991, 6 .

${ }^{4}$ V. Krushenitzkij, "Structurnaya Reorganizatziya Tzerkvi" ("Structural Reorganization of the Church"), Adventistskij Vestnik 1 (1994): 8 . 
Conferences moved to the Trans-European Division, while Belarus, part of the Union Conference, remained in the EuroAsia Division as a separate Conference.

At the present time, the Division is composed of four Union Conferences: the Moldova, Southern, Ukrainian, and West Russian Union Conferences; one Union Mission--the East Russian; and two attached Fields--the Belarus Conference, and the Trans-Caucasus Field. 1

This Division with eleven time zones, nearly 5,770 miles $\left(9,285 \mathrm{kilometers)}\right.$ from east to west, ${ }^{2}$ and a population of $284,887,910$ people $^{3}$ is characterized by great ethnic, religious, and geographical diversity. "Climatic differences" there "are staggering; the eternal ice of the north and the sub-tropical climate in the south yield a temperature difference of 120 degrees centigrade." 4 Russia occupies the largest part of the Division territory; however, over 130 people groups live there. 5 Historically, the Orthodox church represents the main religious force. In

${ }^{1}$ Seventh-day Adventist Yearbook (Hagerstown, MD: Review and Herald Publishing Association, 1996), 149.

2 Ted N. C. Wilson, "God's Miraculous Power in the Euro-Asia Division," Adventist Review, July 7, 1995, 5.

$3_{\text {This figure reflects the situation as of summer }}$ 1995. See Seventh-day Adventist Yearbook, 149.

${ }^{4}$ Johannes Reimer, Operation Soviet Union: How to Pray for the 160 People Groups in the USSR (Fresno, CA: Logos, $1988), 16$.

5 Ibid. 
addition, there are the Roman Catholic church, various Protestant denominations, Islam, Buddhism, Judaism, Shamanism, and a rich spectrum of modern sects. 1

\section{Origin of the SDA Church in the Territory of the Euro-Asia Division}

The Adventist message came to the Russian Empire at the end of the nineteenth century. This state then encompassed "over nine thousand miles from east to west, covering all Eastern Europe and Northern Asia." 2 Moscow, then populated with 700,000 people, was "the center of national life of Russia, the place of the coronation of the czars." 3 The Orthodox church dominated the scene of spiritual and social life. Religious liberty was limited: people of other convictions were allowed to keep the faith of their ancestors or "join the Greek Church; but woe to the man who tries to leave this church to join another." 4 Those who propagated other religious views among the Orthodox people were punished by imprisonment and exile to siberia. 5

${ }^{1}$ Ibid., 20-22.

${ }^{2}$ L. R. Conradi, "A Visit to Russia," in Historical Sketches of the Foreign Missions of the Seventh-day Adventists (Basle: Imprimerie Polyglotte, 1886), 250.

$3_{\text {Ibid. , } 270 .}$

${ }^{4}$ Ibid., 253.

${ }^{5}$ Ibid. 
It is understandable, in this context, why the first Adventists in the Russian Empire were not the fruit of public campaigns. Strangely enough, they were converts of silent witnesses: the Bible and Adventist publications.

It is commonly known that the first Adventists in this part of the world were the "Russian harvest" of "American seed." 1 In the late 1870 s some Russian immigrants of German origin accepted the Adventist message in Minnesota and South Dakota. 2 They sent publications back to Russia and then "heard that some were accepting the 1ight." 3 Nobody knows the exact number of people who were convicted by those tracts. One of them, Gerhard Perk, a former Mennonite, shared a story of his conversion at the GC session in 1909 as follows:

In 1882 a tract entitled "The Third Angel's Message," came into my hand. . . . This tract had been sent from

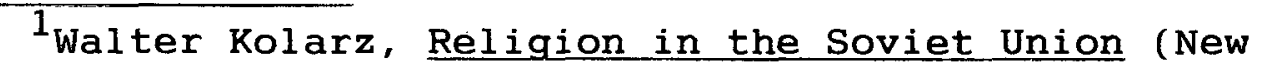
York: St. Martin's Press, 1961), 322. See also Matilda Erickson Andross, Story of the Advent Message (Washington, DC: Review and Herald Publishing Association, 1926), 229230; Sarah Elizabeth Carter, By Jet over Pioneer Footprints (Nashville, TN: Southern Publishing Association, 1967), 43; M. Ellsworth Olsen, Origin and Progress of Seventh-day Adventists (Washington, DC: Review and Herald Publishing Association, 1925), 471-474; Arthur Whitefield Spalding, Origin and History of Seventh-day Adventists (Washington, DC: Review and Herald Publishing Association, 1962), 225228; William A. Spicer, Our Story of Missions for Colleges and Academies (Mountain View, CA: Pacific Press Publishing Association, 1921), 171-172.

${ }^{2}$ Spalding, 226-227.

${ }^{3}$ Spicer, 171 . 
America to one of our village neighbors, who kept it very secretly. . . . He came to me, and said, "For three years I have had some dangerous publications. - . These publications are so dangerous that even an earnest member of the Brethren Church might be led astray by them." . . . I asked my neighbor to let me have this literature. . . For a long time he refused, but finally he consented, . . . after I had promised not to allow any one else to read it. . . . I took the publication, and went into the haymow, and read it through three times; then I copied the address given on the tract. I was af once convinced that the tract I had read was the truth.

The narrative shows that such tracts had a great power over the minds of the people there, and had already reached the southern part of Russia as early as 1879 .

However, God also used another means to bring the Adventist faith to Russia--the Russian Bible. The fact that some people in Russia accepted the Sabbath through personal Bible study is not very well known. One example is F. F. Babienko, who began to keep the Sabbath in the 1870 s as a result of personal investigation of Scriptures. ${ }^{2}$ He became one of the first converts of Conrad Laubhan who came from America in May 1886, to the German colonies in the Volga region. ${ }^{3}$ The group of Babienko's followers--about thirteen

$1_{G}$. Perk, "A Recital of Russian Experiences," in General Conference Bulletin (Washington, DC: General Conference of Seventh-day Adventists, 1909), 52-53.

${ }^{2} \mathrm{~V}$. V. Teppone, Iz Istorii Tzerkvi (From History of the Church) (Kaliningrad: Yantarnij Skaz, 1993), 8, 10-11.

${ }^{3}$ Conradi, 267. 
in number--were baptized in $1887 / 1888$ by the same evangelist. 1

Another person was an officer of the Russian army. He faithfully studied the Bible and raised his children "strictly to it." 2 Through the Bible he "saw the Sabbath," and as his daughter later wrote, "we had to keep it from early youth." 3 Imprisonments and exiles, totaling about thirty years, had not broken his faith. His last desire before death was to strengthen his children "with commandments of Jehovah and the faith of Jesus," and the hope of "the glorious appearing of our Lord and Saviour Jesus Christ." 4

In 1883, the first Adventist missionary came to the Russian Empire. ${ }^{5}$ A German-Russian, he emigrated to America

1 Teppone, 10-11.

${ }^{2}$ L. R. Conradi, "The German-Russian Mission Field," The Advent Review and Sabbath Herald, December 5, 1893, 762 . The daughter of this officer wrote to Adventist workers after she had read an SDA publication in 1893. She related her story as a Sabbath-keeper and expressed her joy that at last she had found people "of the same faith."

3 Ibid.

4 Ibid.

${ }^{5}$ Some authors believe he was Jacob Reiswig--see Emma E. Howel 1, The Great Advent Movement (Washington, DC: Review and Herald Publishing Association, 1935), 155; Olsen, 471. Others give the name of Philipp Reiswig--see Trevor Beeson, Discretion and Valour: Religious Conditions in Russia and Eastern Europe (Philadelphia: Fortress Press, 1982), 96; Kolarz, 323. Still another group (including Conradi who, it seems, personally knew J. Reiswig from Milltown--see Conradi, "A Visit to Russia," 256) refers to him as "one old 
from Crimea in 1878. There he accepted the Adventist message through a tract brought to his family by a colporteur. ${ }^{1}$ His decision to go to Crimea was stimulated by the news of some people converted over there through Adventist publications. 2 This man, aged and poor, prepared a good supply of Adventist literature and went to Odessa where he even "had to sell his boots" since he was paying his own expenses. ${ }^{3}$. He was a great literature evangelist ${ }^{4}$ who served as an encouragement to the new believers. As Conradi later reported: "His visit only increased the desire of the Sabbath-keepers to have a laborer visit and organize them. They were obliged to wait long for help, and when I came they gave me a warm welcome." 5

The year 1886 is considered as being very significant in the history of the Russian Adventist church. In July, the first SDA church was formed by Conradi at Berdebulat "where our brethren and sisters from different places had

gentleman about eighty years old" from South Dakota, without mentioning his name. See L. R. Conradi, "The German and Russian Fields," The Advent Review and Sabbath Herald, April 4, 1893, 214. See also Andross, 230; Spicer, 171.

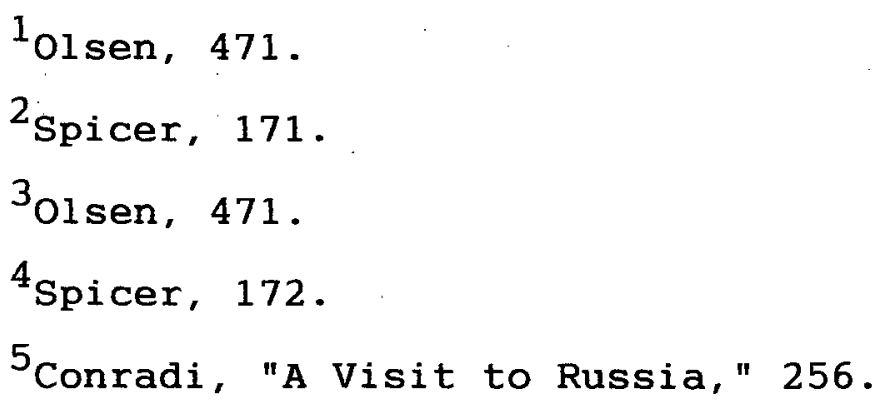


appointed to meet because there was sufficient water here for baptism." 1 Nineteen people "covenanted together to keep the commandments of God and the faith of Jesus, " 2 two women were baptized, and an ordination of an elder and deacon took place. 3 The very next day Conradi and Perk, his interpreter, were imprisoned but finally released after forty days. 4 Then they visited Eastern Russia, and met other Adventist believers there. "Had not these friends been so scattered, and our time so limited, we would have organized a church," Conradi remembered with regret. 5 Reporting on his visit to Russia, he concluded:

The Russian Mission has been opened. Not without cost, it is true. Dangers and difficulties are still in the way. Imprisonment and persecution threaten the laborer. The preacher is not at liberty to present the message. But as it is God's cause, who can hinder? 6

Forty-three years later, H. J. Loebsack, president of the All-Russian Union of the SDA church, gave the following evaluation of Conradi's and Laubhan's contribution:

The Lord blessed their efforts so that soon local officers were developed there, such as colporteurs and ministers. Churches, conferences, and union conferences

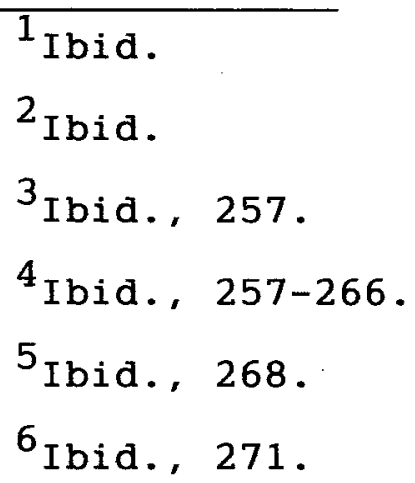


were established all through Russia and Central and Northern Asia, and the message of the soon-coming Saviour was preached from the Pacific Ocean to the Weichsel River, and from Mt. Ararat to the northern ice seas.

\section{Brief Review of Subsequent Growth}

Thus, the foundation of the SDA church in Russia was laid down, and ever since the Adventist membership has been growing. Although approximately thirty people became official members of the church in 1886,2 even then the circle of followers was much wider. As Conradi remarked, that year about eighty had already accepted the truth and some others were scattered all over the Russian Empire, including the Asian part. ${ }^{3}$

In 1890, the SDA church in Russia became an official part of the united German-Russian Conference. 4 Since evangelistic work among Russians was prohibited, most of the converts and workers in Russia for years were of German background. 5 However, some conclude, it was providential

\footnotetext{
${ }^{1}$ H. J. Loebsack, "The Gospel of the Second Advent in Eastern Europe, North and Central Asia," The Advent Review and Sabbath Herald, April 18, 1929, 8-9.

2 Teppone, 14 .

${ }^{3}$ Conradi, "A Visit to Russia," 271 .

${ }^{4}$ Teppone, 13 .

${ }^{5}$ See Conradi, "The German and Russian Fields," 214. Prohibition to proselytize Russians--and strict measures taken by the Orthodox church against those who disobeyed-blocked the work among the native population. In addition, the Adventist literature sent to Russia was in the German
} 
"that the Germans settled in all parts of Russia, so as to leaven the whole lump, as it were, when the time came to give the message in Russia." ${ }^{1}$ Gradually more and more representatives of other ethnic backgrounds, including native Russians, accepted the faith. In 1892, Conradi wrote, "Another branch of our work is the labor among the natives. We had a company of about thirty in the Caucasus, also a company in the east, and some scattered ones." 2 In 1893, he pointed out that there were "Russians keeping the Sabbath" in St.Petersburg. ${ }^{3}$ By 1901 there was already a small Russian congregation in Petersburg. 4 In view of this need, a separate Middle Russian Mission supervising Russian

language. It was only in 1889 that "Russian leaflets were being printed at Basel." See Spicer, 175.

${ }^{1}$ D. P. Gaede, "The West Russian Mission," in General Conference Bulletin (Washington, DC: General Conference of Seventh-day Adventists, 1909), 52. Conradi had the same opinion: "So, around all this large country it is just one continued string of German settlements,--about three millions of Germans in all. What have they been placed there for?--In order to receive the light of the precious truth of the last days and to carry it to the Russians; and the government can't keep it out." Conradi, "The German and Russian Fields," 214.

${ }^{2}$ L. R. Conradi, "The Present Outlook in the Russian Mission," The Advent Review and Sabbath Herald, December 6 , 1892,757 .

3L. R. Conradi, "The German and Russian Field," The Advent Review and Sabbath Herald, April 11, 1893, 230.

${ }^{4}$ Spicer, 178 . 
churches was formed. In 1903 this Mission had over 500 members. 1

After January 1, 1908, the Russian Union Conference (organized in 1907) began to function separately from the German Union. It united the Baltic, Caucasian, and South Russian Conferences with the East, Middle, and West Russian Missions. 2 The president at that time was J. T. Boettcher, and the headquarters of the Union was located in Riga. ${ }^{3}$ The same year, the church had received permission to open a publishing enterprise in Riga. ${ }^{4}$ It began to print Adventist literature in Russian, German, Estonian, Lithuanian, and Polish languages. 5

The following figures show how gradually but surely God strengthened His work in that vast territory; in 1886-30 members, 1890--340 members, 1895--498 members, 1900--1037

1 Teppone, 15-16. The edict of toleration of 1905 in Russia had opened a new opportunity for the Adventist church. That year the Middle Russian Mission was disintegrated, and ever since then the church has had congregations of mixed nationalities.

2 Year Book of the Seventh-day Adventist Denomination (Washington, DC: Review and Herald Publishing Association, 1908), 111-114.

3 Ibid.

${ }^{4}$ Spicer, 180.

${ }^{5}$ Teppone, 20 . 
members, $^{1} 1905--2,011,2$ and $1910--3,952$ members. $^{3}$ In 1916, one year before the October Revolution, the membership was $6,720.4$ One should place this success within the framework of persecution, World War I, political instability, and emigration of some members abroad. 5

After the October Revolution, there were about twelve years of relative religious freedom. 6 Nevertheless, people, including Adventists, suffered from the civil war, chaos, poverty, epidemics, and terrible famine. 7 However, the

$1_{\text {Ibid., }} 14-15$.

${ }^{2}$ Year Book of the Seventh-Day Adventist Denomination $(1906), 73-75$.

3 Teppone, 35-40.

${ }^{4}$ Christel Lane, Christian Religion in the Soviet Union (Albany: State University of New York Press, 1978). 167.

${ }^{5}$ See Conradi, "The Present Outlook in the Russian Mission," 757. Daniel Heinz, "Adventists Celebrate Centennial of Church in Soviet Union," Adventist Review, May $10,1984,13$, writes that by 1900 "the church had grown to more than 1,000 members; at least 300 others had emigrated to other parts of Europe or to America." Heinz, 14, also adds that "with the outbreak of World War I, many Adventists, especially those of German origin, were treated as revolutionaries by the czarist regime."

$6 \mathrm{~J}$. W. Hirlinger, "Conditions in Russia," The Advent Review and Sabbath Herald, February 27, 1919, 26. See also Loebsack, 9 .

7 L. H. Christian, "Europe's Call to America," The Advent Review and Sabbath Herald, December 9, 1920, $1 \overline{1-16 .}$ See also, idem, "The Russian Tragedy," The Advent Review and Sabbath Herald, October 27, 1921, 24, and Hirlinger, 26. 
church still grew in spite of these hardships. 1

Early in 1923 there were six Union Conferences, 9,034 members, and 381 congregations. ${ }^{2} 1,237$ people were added to the church just during the second quarter of that year. ${ }^{3}$ Early in 1926, it was reported that "12,282 members gathered from twenty different nationalities." 4 At the beginning of 1929, there were "13,547 members, comprising twenty-nine nationalities." 5

In 1929 the U.S.S.R. government chose a new approach toward religious denominations. A change made in the Soviet constitution regarding religious freedom ${ }^{6}$ initiated severe persecution. The following record shows tremendous losses in the SDA church in the 1930s: "nearly 3,000 of our members were subjected to repression," and "of the 150 preachers that the church had at that time, only two were not arrested." 7 Since this oppression lasted over two decades, 8

$1_{\text {M. Demidov, "An Appeal from Russia," The Advent }}$ Review and Sabbath Herald, June 5, 1919, 32 .

2 Year Book of the Seventh-day Adventist Denomination (1924), 105-111.

${ }^{3}$ J. T. Boettcher, "Good News from Russia," The Advent Review and Sabbath Herald, December 20, 1923, 9.

${ }^{4}$ W. K. Ising, "The Work in Russia," Missions Quarterly 1 (1927): 19 .

${ }^{5}$ Loebsack , 9 .

6 Teppone, 267 .

7M. P. Kulakov, "When KGB Came Calling," Liberty, January/February, 1994, 18. See also, Anna Matzanova and 
the number of religious prisoners increased. The following information was obviously gathered some time after the thirties, when the prisoners of the first wave of persecution began to return, and this can be a possible explanation for the different number of imprisoned pastors: "Of 3,000 Seventh-day Adventists sent to prison camps, only 500 returned. Of 179 Adventist pastors taken, only four returned." 1 Nevertheless, with God's power, the church has survived. "The members who weren't imprisoned met secretly in private homes, risking imprisonment and death." 2 As some sources state, the church began to grow again after the Second World war. 3

However, official records of Adventist membership in the Soviet Union were not known to the worldwide church for a long time. Between 1931 and 1950, there were no statistics on the Adventist church in the U.S.S.R. in the

Pavel Matzanov, Po Ternistomu Puti (By the Thorny Way) (Kaliningrad: Yantarnij Skaz, 1995), 11.

${ }^{8}$ Stalin's death in 1953 brought release to many political and religious prisoners, and also a short-term (about five to six years) positive change in the direction of the new government toward religion. See Matzanova and Matzanov, 117, 155, 162, 175, 181 .

${ }^{1}$ Roland R. Hegstad, "Challenge At," Liberty, March/Apri1, 1991, 11 .

2 "World Report: Thousands Hear of God's Love," Adventist Review, July 14, 1994, 19. See also Hegstad, 11 .

${ }^{3}$ Beeson, 96. See also Lane, 167 . 
Seventh-day Adventist Yearbook. In 1951, a short message appeared: 834 churches, 21,611 members, and this remark:

"Numbers of churches and members are estimates based on latest figures available." 1 Between 1956 and 1981 , there was the following record: "churches, 834, members, 40,000" with the same comment on estimates. ${ }^{2}$

According to the Soviet sources, there were 12,500 Adventists in 1947 and 21,500 in 1964.3 Some others point to 26,000 members in the 1950s with an assumption that "the actual size of the movement was very much larger." 4 The known sizes of the biggest Adventist congregations in the 1950s are surprisingly large: Riga--900, Tallin--600, Moscow--500, Kiev--300, 5 Rostov-on-Don--over 100 members. 6 The year 1959 marked a new wave of repression. 7 In 1960 the government dismissed the SDA All-Union Council in

${ }^{1}$ Seventh-day Adventist Yearbook (1951), 233. The same information is presented in the 1952, 1953, 1954, and 1955 yearbooks.

\section{${ }^{2}$ Seventh-day Adventist Yearbook (1956-1981). \\ ${ }^{3}$ Religion in the U.S.S.R., ed. Robert Conquest (New} York: Frederick A. Praeger, 1968), 111.

${ }^{4}$ Beeson, 96. See also Kolarz, 325.

${ }^{5}$ Kol arz , 325-326.

6 Matzanova and Matzanov, 111, 118 .

${ }^{7}$ Ibid., 162. The following two examples can illustrate this change in the Soviet government's attitude towards religion: (1) in 1954 (ibid., 117), N. S. Khruschev's speech was published in the newspapers stating that religious people should not be considered as dangerous 
Moscow. The archives, all documents, and books were confiscated from the office. The president was prohibited from addressing the believers from the pulpit, and the license of the secretary was taken away. Adventist communities began to function as autonomous units. 1 Total membership in the 1960s is still unknown. There is some evidence that it was about $37,000,{ }^{2}$ but it is hard to verify this figure.

In the 1970s, the attitude of the government towards religion was slowly changing in a positive direction. In 1971, a contact with the SDA worldwide church was reestablished. 3 In 1975 an Adventist delegation from U.S.S.R. attended the GC session in Vienna, Austria. Since that time, representatives of the SDA church in the Soviet

for the Soviet state; (2) in 1960, the same Khruschev "vowed that within 20 years there would not be a single believer in the entire Soviet Union," see Rose Otis, "GC President Addresses Largest Gathering of Ukrainian Adventists," Adventist Review, April 26, 1990, 20. Dimitry Pospielovsky in The Russian Church under the Soviet Regime 1917-1982 (Crestwood, NY: St. Vladimir's Seminary Press, 1984), 327, $328 f f .$, states that "mass closure of churches, monasteries and seminaries and the general persecution of 1959-1960" is connected with the fact that in the 1950s "both the Orthodox Church and the sectarians were successfully attracting the younger generations to the Church by high-quality sermons, charity work, individual indoctrination and the religious press."

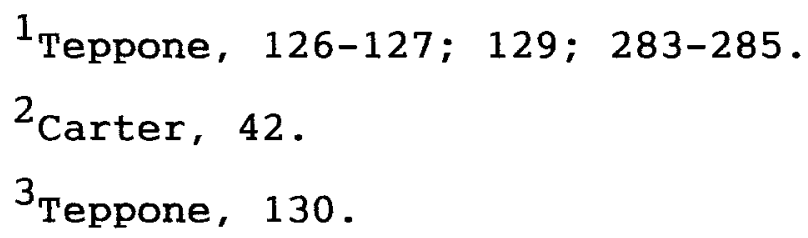


Union have participated in the main worldwide church conventions. 1 In 1977, the Council of the SDA church of the Russian Federated Republic was formed with M. P. Kulakov as the president. This Council tried to supervise the work in all the territory of the U.S.S.R. ${ }^{2}$ Since 1977, the church has enjoyed visits of GC representatives on a regular basis. 3 The first visit of a GC president--then Robert $H$. Pierson--was in 1978. In 1981, a visit of the next GC president---Neal C. Wilson--brought a reunion between two factions in the church. 4

Then, "for the first time in approximately 30 years, the Seventh-day Adventist Church was able to gather fairly accurate information regarding its membership," which reached 30,604 in October $1981 .^{5}$ Adventists in this country were described by Alf Lohne as "faithful to Seventh-day doctrines," very respectful toward the GC, having great "interest in attending prayer meetings," and an earnest "desire to hear God's Word." 6 At the end of 1982 there were

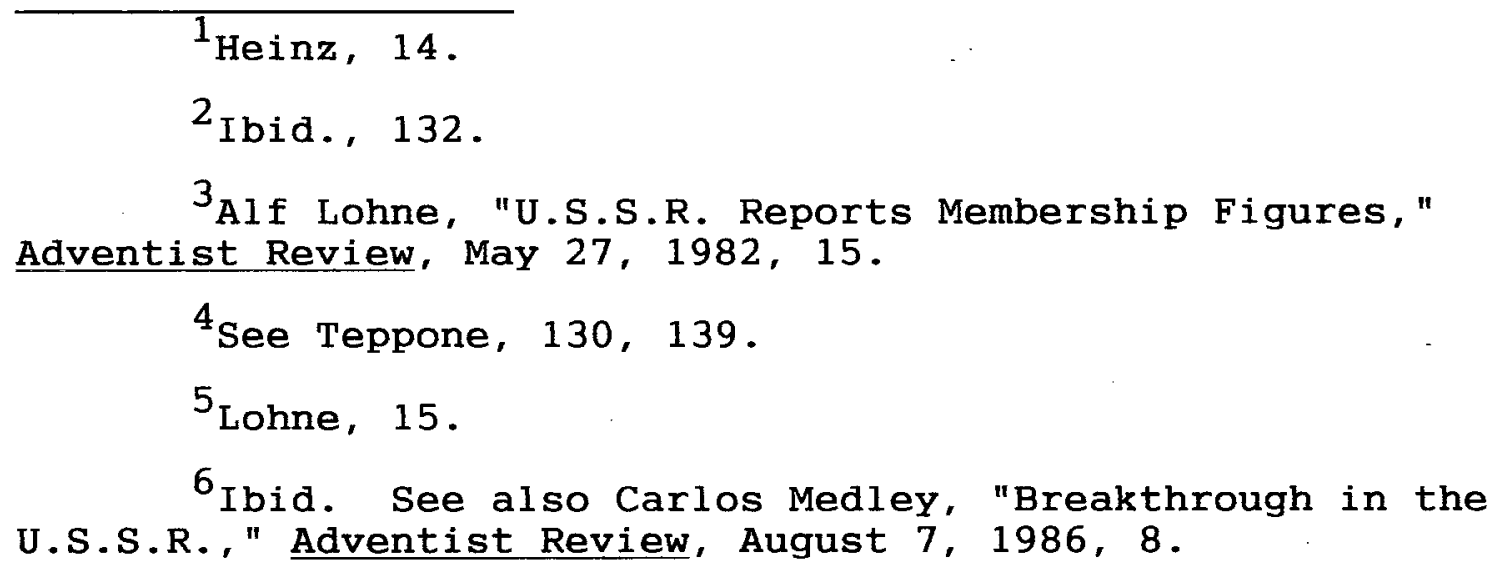


30,344 members, in $1983--30,547$, in $1984--31,000$, in 1985-$31,305.1$

Church Growth in the Euro-Asia

Division during 1985-1995

This section presents the 1985-1995 period from a perspective of church-growth opportunities for the Euro-Asia Division. It also points to the important changes and achievements of the Adventist church. In addition, an increase and decrease of the church membership is analyzed, and some weak points of the infrastructure are focused on. The period under investigation is from the year ending December 31, 1985 till the year ending December 31, 1995.

\section{5-1995--a Decade of New Opportunities}

The years 1985-1995 became a century-awaited answer to the prayers of Adventists from the former Soviet Union. As was mentioned above, the first Adventist congregation in this part of the world was formed in 1886 . Thus 1986 marked one hundred years of the SDA church in this territory. Interestingly enough, another event of 1986--the Chernobyl nuclear explosion--stands as a symbol of the coming collapse of the whole Soviet system. However, while the nuclear explosion was a disaster, the gradual collapse of the

${ }^{1} 124$ th Annual Statistical Report 1986 (Washington, DC: General Conference of Seventh-day Adventists, 1987), 2 . 
communist regime brought tremendous changes and opportunities in favor of religious freedom.

This decade can be divided into two significant periods: 1985-1990--a period of transition and new opportunities, and 1991-1995--a period of public evangelism.

A Period of Transition and New Opportunities: $1985-1990$

During the first period, both the state and the church underwent a transition. The U.S.S.R. began to move from its traditional policy towards a new direction of glastnost and perestroika. Gradually, "strong winds of long-expected liberty" began to blow. "The government not only abandoned all limitations on the construction of new church buildings, but has been returning those buildings that were taken away in the past." 1 This made it possible for Adventists to begin building 236 new churches in this period. 2

The old system of communist ideology was coming to its collapse. Many of the Soviet people had been going through painful disappointments and great spiritual hunger. As one described it: "The society now stands before God empty-handed in desperation, with great bitterness towards

\footnotetext{
$1_{\text {M. P. Kulakov, "Bright Prospects in the U.S.S.R," }}$ Adventist Review, July 12, 1990, 22 .

2 Ibid., 23 .
} 
their false gods and corrupt leaders of the past, who brought the country to ruin." 1 Such a situation created overwhelming interest in religious matters and literature:

"Nobody is buying the works of the fathers of atheism in Russia anymore. Everybody, from a factory worker to a university professor, wants to own a Bible." 2

The Adventist church took these opening opportunities to reach the Soviet people through different kinds of activities. The result was a great awakening. Large numbers of people gathered at public halls rented by Adventists to listen to their "charity concerts of Christian music" with "short Bible-based evangelistic sermons." 3 Hundreds of them asked for a Bible, 4 which became "the runaway best seller" 5 of the late eighties and early nineties. "Two million Bibles were distributed to believers in 1988 and 1989, with millions more finding their way into eager hands in the early 1990s." 6 Bible courses have been

${ }^{1}$ Mikhail Kulakov, God's Soviet Miracles (Boise, ID: Pacific Press Publishing Association, 1993), 12.

2 Ibid., 14 .

${ }^{3}$ M. P. Kulakov, "Bright Prospects in the U.S.S.R.," 22

${ }^{4}$ Ibid., 24 .

5 Mark Finley, The Cross and the Kremlin (Fallbrook, CA: Hart Research Center, 1992), 15.

6 Ibid. 
organized in many places including prisons and hospitals. 1 In January 1987, Adventists received permission to open the first Protestant seminary in the Soviet Union. Zaokski Seminary was reconstructed from a burned-out school and opened "after 22 months of hard work, sacrificial giving, and careful planning . . on December 2, 1988."2 Restoration expenses, totaling a sum of approximately US $\$ 2.43$ million, were mostly covered by donations of the church members from the Soviet Union. ${ }^{3}$

The Zaokski Seminary, a miracle by itself, began to perform not only educational functions but a missionary one as well. Thousands of people, including "teachers, engineers, scientists, and medical doctors," and common people visited the seminary. "They participate in our worship services with great interest. They attend our lectures, talk to our students and faculty, and listen intently while showing an intense hunger for the Bread of 24

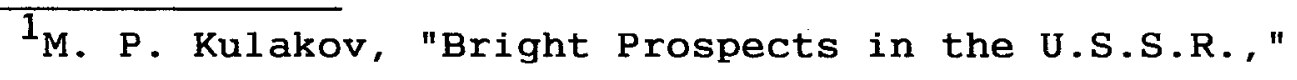

${ }^{2}$ Rose Otis, "Adventist Church Dedicates First Seminary in U.S.S.R.," Adventist Review, February 16, 1989, 6 .

3Ibid. This author relates that "the world church showed its support of the project by providing the heating and phone systems and furnishings for the classrooms, offices, and cafeteria, and books for the library," 6 . Some members of the church from the U.S.S.R. gave even their whole life savings. For one such example, see M. P. Kulakov, "Bright Prospects in the U.S.S.R.," 23. 
Life." 1 As a result of this interest and earnest efforts of the seminary students, "six satellite churches were formed" around Zaokski by 1992. 2

The Seminary has recognized a great need for pastors in this rapidly growing Division. It has not limited itself only to a four-year on-campus course (undergraduate level), and an extention master's program. It also began to train local pastors through intensive training courses and extension programs in different parts of the Division. 3 Since autumn of 1990 , the Adventist radio network called "Voice of Hope" "began broadcasting in Tula and a number of other cities in the soviet Union." 4 It has received an overwhelming feedback from the people of the Commonwealth of the former Soviet republics: "five hundred letters a day come. . . 300 of which request the New Life Bible course." 5 In October of 1995, this Media Center celebrated its fifth anniversary. 6 During that time "the

\footnotetext{
${ }^{1}$ Mikhail Kulakov, 23.

${ }^{2}$ Ibid., 127 .

3ilson, 7 .

${ }^{4}$ Rose Otis, "Sabbath Schools, Radio Studio Benefit from Shipment," Adventist Review, June 13, 1991, 18.

${ }^{5}$ Daniel R. Guild, "Adventist Radio Blankets Former Soviet Union," Adventist Review, December 31, 1992, 21.

6 "World Church News: Russian Bible School Graduates More Than 18,000 in First Five Years," Lake Union Herald, January 1996, 21 .
} 
center received 327,122 letters and mailed out 495,191 letters," and "more than 18,000 people have completed the New Life Bible lessons from the Bible Correspondence School."1 In 1995, there were nearly 60,000 correspondence students at this Media Center. ${ }^{2}$

It was during this period, 1985-1990, that Adventists in the U.S.S.R. had the opportunity to join the worldwide SDA church in its mission enterprise for the first time since the closing of religious freedom by Soviet government in 1929. The program was "Harvest-90" with its global "basic goal of 2 million" new converts and "the super goal of 2.5 million" members added between the GC summer sessions of 1985 and $1990 . .^{3}$ Adventists in the Soviet Union "had a Harvest 90 goal of 4,000 , but baptisms soared to $8,344^{4}$ by the end of 1.989. In addition, more than 1,896 members were baptized on the specially appointed Victory Baptism day--May 26, 1990.5 Thus, the total contribution of this Division to

$1_{\text {Ibid. }}$ $2_{\text {Wilson, } 7 \text {. }}$

${ }^{3}$ Carlos E. Aeschlimann, "Harvest 90 Exceeds Expectations," Adventist Review, November 22, 1990, 20.

${ }^{4}$ Ibid., 21. See also 128th Annual Statistical Report--1990 (Silver Spring, MD: General Conference of Seventh-day Adventists, 1991), 2 . 24 .

${ }^{5}$ M. P. Kulakov, "Bright Prospects in the U.S.S.R.," 
the worldwide Adventist program "Harvest-90" was more than 10,240 new members.

As mentioned above, 1985-1990 was a period of transition for the Adventist church in this country. During that time, it was trying to find an adequate role in the context of rapid changes and possibilities. The formation of the Division of the Soviet Socialist Republics in $1990^{1}$ became the climax of this transitional period.

\section{A Period of Public Evangelism 1991-1995}

The period of 1991-1995 was by itself even more unusual. "Russia seems caught up in an amazing kaleidoscope of the old and the new." 2 Like the state, the Adventist church in this Division became willing to implement old (for the worldwide church) but new (for the Division) methods and practices. One such "innovation" was a "new" approach to soul winning, namely, public evangelism. It especially marked the first three years of this period with its colorful characteristics.

The realization of this approach became possible due to the joined efforts of the GC leadership, international evangelists, and SDA members from inside the country and

\footnotetext{
${ }^{1}$ See p. 11, above.

${ }^{2}$ William G. Johnsson, "The Risen Christ over Red Square," Adventist Review, June 18, 1992, 13.
} 
abroad. In 1989, the Soviet Union, China, India, and the Middle East were chosen as direct areas for General Conference mission involvement. ${ }^{1}$ In October $1990, \mathrm{~J}$. R. Spangler was appointed evangelism consultant for the U.S.S.R. Division by the GC president. ${ }^{2}$ He foresaw the wonderful opportunities opened for public evangelism in this country. In the beginning of 1991 he wrote that "the political, economic and social situation in the U.S.S.R. is frightening, maybe at crisis stage. What we as Seventh-day Adventists do in evangelizing the U.S.S.R. must be done immediately." 3 promotion of short evangelistic campaigns "in every city and town, especially where there are church members" 4 was accepted by the leaders of the Division.

In the spring of 1991, M. P. Kulakov and R. Spangler laid plans for eleven four-week field schools of evangelism in the Soviet Union during the summer and fall. 5 These schools were to be conducted by foreign evangelists and were

1 "world Report: Actions of General Interest from the 1989 Annual Council--1," Adventist Review, January 11, 1990, 23.

${ }^{2}$ Daniel R. Guild, "Evangelism Schools to Convene in Newest Division," Adventist Review, June 27, 1991, 23.

3 J. R. Spangler, "The Soviet Union: A Decade of Destiny," Adventist Review, February 7, 1991, 8.

${ }^{4}$ Ibid. , 10 .

${ }^{5}$ Guild, "Evangelism Schools to Convene in Newest Division," 23. 
to be combined with evangelistic crusades. ${ }^{1}$ Pastors of the Division who had never had an experience of conducting evangelistic meetings had a chance to be richly blessed. According to the schedule, they had to "receive instruction in preaching and evangelistic methods each morning, visit interested persons in the afternoon, and assist with evangelistic meetings in the evening." 2 The purpose of these schools was to enable the pastors to conduct evangelistic crusades later by themselves. 3

Since that time, public evangelism has become the main missionary method in the Division. Public halls rented for this purpose were overcrowded in practically every place, and thousands have been baptized. The following examples present just some of the results of this historic period.

In 1991,450 people were baptized out of a nightly attendance of 3,000 in Moscow. ${ }^{4}$ New members numbering 132 were added in Lvov; 120 in Tashkent; 5 and 323 in

\footnotetext{
I"Newsbreak: Evangel ism Blossoms in the Soviet Union," Adventist Review, August 15, 1991, 6.

${ }^{2}$ Guild, "Evangelism Schools to Convene in Newest Division, " 23.

3 Ibid. Union," 6 .

4 "Newsbreak: Evangelism Blossoms in the Soviet ${ }^{5}$ Ibid.
} 
Petersburg. ${ }^{1}$ In Rostov-on-Don, 263 people were baptized out of more than 3,500 who attended every night of the crusade. 2 In 1991, there were a total of twenty crusades conducted by foreign evangelists, "over 50,000 attended evangelistic meetings, with nearly 12,000 people baptized." 3

In 1992, 405 new members were added and "an additional 150 were enrolled in the baptismal class" in Petersburg. 4 As a result of Operation Bearhug, 5 "more than 120" volunteers from the Upper Columbia Conference visited a far-Siberian city, Magadan. 6 with their help an evangelistic campaign with an attendance of $11,000-1,100$ each evening" was conducted, 278 people were baptized, increasing the church membership from "approximately 60 to 320 members," and a "three-story 400-seat church" was constructed. 7

${ }^{1}$ Daniel R. Guild, "Meetings Triple Membership in St. Petersburg," Adventist Review, March 19, 1992, 19.

${ }^{2}$ James H. Zachary, "I Felt God's Power in Rostov," Adventist Review, October 3, 1991, 9.

3 Finley, 22 .

4 "World Report: Mission Outreach Spurs Local Church Growth," Adventist Review, November 12, 1992, 21.

${ }^{5}$ Operation Bearhug is the sister Union relationship between the Russian Union and the North Pacific Union Conferences, resuting in joined efforts in evangelism in the Euro-Asia Division.

${ }^{6}$ Cindy Chamberlin, "Operation Bearhug Reaches Across Pacific," Adventist Review, November 19, 1992, 20.

${ }^{7}$ Ibid. 
The same year, a famous crusade by Mark Finley in the Kremlin Palace in Moscow surprised all by the overwhelming interest of the people. It had been said by the Kremlin officials that "the only way to control the crowds" was to sell the seats. 1 More than 11,000 tickets had already been sold one week before the campaign. "People stood in line for four hours to purchase the seats" and were even "willing to pay the equivalent of two week's salary" to get the ticket. 2 As a result, over 12,000 people attended every night, 1,300 were added to the SDA church, and 77,000 Bible lessons and 20,000 Bibles were distributed. 3 The Moscow membership was enlarged to about 3,000 , resulting in four congregations. 4

In Nizhni Novgorod, the same year, 12,000 people attended each of two evening meetings conducted by John Carter. At the end of this evangelistic series, 2,520 of them were baptized. 5 As Carter reported: "We brought 13,000 Bibles. We ended up giving away 25,000, and we could have

\footnotetext{
${ }^{1}$ Finley, 29.

2 Ibid.

3 "Newsbreak: Kremlin Evangelistic Series Brings Major Harvest," Adventist Review, May 28, 1992, 6.

4 Janet Leigh Kangas, "Offering Will Provide Institutions for Newest Division, " Adventist Review, December 17, 1992, 20.

5 "Newsbreak: Russian Outreach Series Brings 2,520 Baptisms," Adventist Review, July 30, 1992, 6.
} 
used 25,000 more." 1 In 1992, a total of 86 evangelistic crusades were conducted by the foreign evangelists and about 200 by the local pastors. 2

One of the biggest events of 1993 was an evangelistic campaign in the Olympic Stadium in Moscow conducted by Finley. "About 16,000 people attended the afternoon and evening sessions," and "10,000 were still attending" at the last meeting. ${ }^{3}$ This series was planned to "be both a world field school of evangelism and a soul-winning crusade for Russia's capital city." 4 At the end of the crusade, "almost 1,600 had been baptized, and more than 4,000 are being followed up," increasing the number of Moscow congregations from four to twelve. 5 The $1993 \mathrm{plan}$ included 125 campaigns by foreign evangelists and the same number by local pastors. 6 It is known that " 89 seminars by 83 international evangelists" made a contribution of "13,880 baptisms, "7

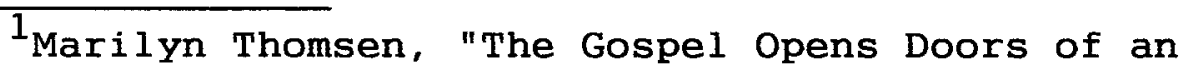
Isolated City," Adventist Review, August 20, 1992, 6.

2 "Newsbreak: Euro-Asia Update," Adventist Review, December 17, 1992, 7 .

$3^{J}$. David Newman and Sharon Cress, "Super Evangelism in Moscow, " Ministry, November 1993, 15.

${ }^{4} \mathrm{~J}$. R. Spangler, "Evangel ism Goes to Moscow," Ministry, March 1993, 7.

${ }^{5}$ Newman and Cress, 16.

${ }^{6}$ Spangler, "Evangelism Goes to Moscow," 6 .

${ }^{7}$ Charles R. Taylor, "Making up for Lost Time," Adventist Review, December 22, 1994, 20. 
which was almost half of the total accessions of that year. In 1994, public campaigns were still going all over the Division territory. In Poltava, Ukraine, for instance, "almost 4,400 different people attended the meetings," and 1,025 of them were baptized. ${ }^{1}$ In Astrakhan, Russia, more than 120 people were baptized the same year. 2 "During the first half of 1994, national Seventh-day Adventist ministers held more than 120 evangelistic campaigns, baptized more than 6,000 members. . . International evangelists--from the Americas, Europe, and Australia--held 35 campaigns, baptized about 5,000 members." 3

In 1995, new people were added to the church through public evangelism. Then the biggest campaign ever conducted in the Euro-Asia Division was held in Kiev "by local Adventist leaders and the John Carter evangelistic team." 4 Total baptisms brought 3,487 new members ${ }^{5}$ out of a nightly attendance of 13,000; "30,000 Ellen G. White books have been

\footnotetext{
"World Report: Thousands Hear of God's Love," 19-20.

${ }^{2}$ Konrad Mueller, "Redeeming the Past, " Adventist Review, March 30, 1995, 18-19.

3 Taylor, 18 .

4 "Newsbreak: Ukrainian Update," Adventist Review, September 14, 1995, 6 .

${ }^{5}$ Beverley Carter, "Pentecost Revisited," Adventist Review, November 9, 1995, 21 .
} 
distributed," 1 and 25,000 people "who had attended at least seven meetings" were given "a Russian-Ukrainian copy of the Holy Scripture." 2 The same year, in one of the Belarus towns, Rechintzsa, the church membership grew from 5 to 255 after an evangelistic meeting was held by a local pastor. 3 Adventists in the Euro-Asia Division have used other methods of reaching people during this period as well. One such method is charitable ministries. As Ralph Watts, ADRA's president, reports in 1992, "The needs in the republics are extremely critical. Food shortages have not been exaggerated. There is no question that people are hungry." 4 Although the situation has gradually been changing, there are still a lot of needy people. ADRA in the Euro-Asia Division took the responsibility of helping them. They opened in Moscow a Soup Kitchen for the elderly in 1992.5 In 1995, such Soup Kitchens have been established in Erevan, Pinsk/Minsk, Moscow, Vladicaucasus, and Kiev. 6

\footnotetext{
1 "Newsbreak: Ukrainian Update, " Adventist Review, August $31,1995,6$.

${ }^{2}$ Beverley Carter, 21 .

3 "Newsbreak: Belarus Meetings Bring 250 Baptisms," Adventist Review, April 1995, 7.

4 "Newsbreak: ADRA Prepares to Ship Food to Former Soviet Republics," Adventist Review, February 20, 1992, 6.

${ }^{5}$ William Johnsson, "Snapshots of Russia and the Ukraine," Adventist Review, June 25, 1992, 9-10.

6 "Godovoj Otchet ADRA Evropejskogo-Aziatskogo Diviziona" ("Annual Report of ADRA of the Euro-Asia
} 
The following are some of many ADRA actions performed in 1995: About 120 tons of food and clothes were distributed in the area of the Chechen war. Fifty orphaned children in Podolsk and 750 Belarus children (with new plans for more than 600) who had suffered in the Chernobyl explosion were helped. About 5,000 survivors of the terrible earthquake in Sakhalin have received ADRA's help. ${ }^{1}$ After five years of work, ADRA of the Euro-Asia Division was "favorably recognized in public and government circles." 2

Since 1992, the newly built Adventist publishing house became an important element in providing church leaders and lay members with Adventist literature and thus giving an impetus to literature evangelism. 3 "Adventists in the former Soviet Union are spreading Bibles like the leaves of autumn. Church leaders distributed 51 tons of Bibles and Bible lessons across 3,800 miles to 90 percent of the Adventist congregations there." 4

Division") in Reports (Moscow: The Euro-Asia Division, $1995), 14$.

${ }^{1}$ Ibid., 14-15.

2 wilson, 6 .

3 "Newsbreak: First Adventist Journal Printed in Russia," Adventist Review, December 17, 1992, 7.

4 "Newsbreak: New Bibles Distributed in Russia," Adventist Review, March 23, 1995, 6 . 
The work for a healthy lifestyle has gradually been widening in the Division. In the summer of 1992, "a group of 10 American youth went to Russia" with a purpose "to combat the alcoholism and drug dependency that controls the lives of millions in the former soviet republics." 1 Fourtyfive trainees took three-week seminars with the challenge to conduct "their own Youth to Youth conference in Moscow" 2 starting the next day after their graduation. The Russian version of Youth to Youth "attracted 165 young people from all over the CIS." 3 Usually there was a good response to the Healthy Life Style seminars. Some evangelists also conducted such series in conjunction with their evangelistic crusades.

There are six SDA elementary and secondary schools in the territory of the Division: four of them are located in Russia and two in the Ukraine. The total number of students in 1995 was 513.4 The schools provide an excellent setting for witnessing to non-Adventist children and their parents. In addition, there is a "public schools' evangelism project"

\footnotetext{
${ }^{1}$ Curt Dewees, "Youth Train Peers to Teach Temperance," Adventist Review, November 26, 1992, 18.

2 Ibid., 20 .

3 Ibid.

${ }^{4}$ wilson, 6 .
} 
providing seminars based on Bible teaching for children in public schools. 1

Women's ministries have begun to play a special part in the Euro-Asia Division. Adventist women have always been actively involved in the church work there. However, there is again a great need for their involvement since, as one noted in 1993, "the membership in Russia is between 60 and 70 percent female." 2 The power of their ministry in this Division is seen from the following figures: during the first half of 1995, 717 people were baptized as a result of their meetings. In nine months, during the same year, five evangelistic programs were conducted with 192 people baptized, and five churches were formed. 3

During the last two years of the 1991-1995 period, there has been a special emphasis on lay evangelism. The following examples present the picture of lay involvement in the evangelistic work in the Division. In Novomoskovks, Russia, a small Adventist group of seventeen, without a pastor, elder, or deacons, grew to a sixty-five-member congregation because of the effort of lay members and especially three women who "kept the church alive--even

\footnotetext{
${ }^{1}$ Ibid., 7.

${ }^{2}$ Harold Butler and Peter Koolik, "Euro-Asia: 500 Churches to Build," Adventist Review, August 5, 1993, 25.

3 "Sluzhenie Zhenschin" ("Women's Ministries") in Reports, 33 .
} 
adding new members" for four years. 1 After the "witnessing training project" in the Euro-Asia Division by about fortyfive volunteers from the United States, "more than 4,500 church members participated in door-to-door witnessing, conducted religious surveys, and invited neighbors to study the Bible."2 As a result, they "contacted more than 25,000 homes and enrolled nearly 6,000 persons in new Bible studies." 3 Another report shows that " 378 members in the West Russian Union were responsible for more than 1,100 persons joining the Adventist Church in 1995." 4 As a result of the lay evangelism project, 564 people were added to the Eastern Ukrainian Conference. 5 The growing involvement of lay people in evangelism is seen from the following figures: in 1994, 4 percent of members in the Division had been preparing their relatives for baptism; in 1995 the number grew to 13 percent. 6

\footnotetext{
${ }^{1}$ Natasha Ivanova, "Four Years without Holidays," Adventist Review, special issue, June 1995, 20.

2 "Newsbreak: Volunteers Hold Training Sessions in Eastern Europe," Adventist Review, June 22, 1995, 7.

${ }^{3}$ Ibid.

4 "Newsbreak: Russian Members' Witness Leads to 1,100 Baptisms," Adventist Review, January 25, 1996, 7 .

5 "Newsbreak: Lay Evangelism Brings New Baptisms in Ukraine," Adventist Review, August 17, 1995, 6 .

6 "Otchet Otdela Subbotnej Shkoli i Ryadovikh Missionerov" ("Report of Sabbath School and Lay Missionaries' Department") in Reports, 17.
} 
At the 1990 GC session, a special program called "Global Mission" was voted. According to this program, the world population was divided into segments of one million with plans to establish an Adventist presence in every unentered one. ${ }^{1}$ That year, the Euro-Asia Division was comprised of 295 such one million segments--approximately 62 of them unentered. 2 By 1994, officially organized congregations or companies of believers were established in 18 of these unentered segments. ${ }^{3}$ The ratio of people per one Adventist in this Division has changed during this period also: in $1990--8,147: 1 ;^{4}$ in $1991--7,769: 1 ;^{5}$ in $1992--$ $4,958: 1 ;^{6}$ in $1993--3,684: 1,7$ in $1994--3,037: 1,8$ in $1995--$ $2,769: 1.9$

$1_{\text {Michael Ryan and Shephen Chavez, "Intentional }}$ Outreach," Adventist Review, June 1995, 10-11. See also Charles R. Taylor, "Measuring a Dream," Adventist Review, June 1995, 8-9.

2 128th Annual Statistical Report--1990, 45 .

3132nd Annual Statistical Report--1994, (Silver Spring, MD: General Conference of Seventh-day Adventists, 1995), 41 .

${ }^{4} \mathrm{Calculations}$ are done on the basis of information presented in Seventh-day Adventist Yearbook (Hagerstown, MD: Review and Herald Publishing Association, 1991), 340.

${ }^{5}$ Seventh-day Adventist Yearbook (1992), 104.

${ }^{6}$ Seventh-day Adventist Yearbook (1993), 99.

${ }^{7}$ Seventh-day Adventist Yearbook (1994), 99.

${ }^{8}$ Seventh-day Adventist Yearbook (1995), 101.

${ }^{9}$ Seventh-day Adventist Yearbook (1996), 148. 
At the same time, an awareness of unreached people all around the world is growing among Adventists in the Euro-Asia Division. As James A. Cress states, "Russian Adventists see themselves as part of Global Mission. I was encouraged to see 100 pastors earnestly praying for large cities such as New York, Hong Kong, and London." 1 The following examples also show the growing insight for the worldwide mission of Adventists in the Euro-Asia Division. In 1995, for the first time, a group of three from the Division went to a country of another Division (Yugoslavia) to conduct an evangelistic campaign. 2 The publishing house of the Division sends seventeen copies of the Sabbath School Quarterly four times a year to Israel for immigrants from the former Soviet Union. 3

\section{An Analysis of the Increase of the Church Membership in the Euro-Asia Division during 1985-1995}

In the context of these changes, the church membership of the Euro-Asia Division has grown tremendously during the 1985-1995 decade. This subsection presents the

${ }^{1}$ James A. Cress, "The Russians Are Coming, " Ministry, November 1993, 24 . Reports, 2 .

2 "Otchet Secretarya" ("Report of the Secretary"), in

${ }^{3}$ V. M. Zavadskij, "Rabota s Evreyami" ("Work with Jews") in Reports, 31 . 
church membership growth, statistics on accessions, and annual and decadal growth rates of the Division. 1

Figure 1 and table 1 show steady year by year membership increase during this decade.

Table 1

Church Membership in the Euro-Asia Division in the 1985-1995 Period

\begin{tabular}{ll}
\hline Year & Membership \\
\hline 1985 & 31,305 \\
\hline 1986 & 31,679 \\
\hline 1987 & 32,057 \\
\hline 1988 & 32,392 \\
\hline 1989 & 34,146 \\
\hline 1990 & 37,388 \\
\hline 1992 & 46,623 \\
\hline 1993 & 71,873 \\
\hline 1994 & 95,885 \\
\hline 1995 & 98,963 \\
\hline
\end{tabular}

Source: Data are based on the 127th Annual Statistical Report 1989 (Silver Spring, MD: General Conference of Seventh-day Adventists, 1990), 2; the 132nd Annual Statistical Report--1994, 2. Data for 1995 are presented on the basis of information supplied by the secretary of the Euro-Asia Division.

${ }^{1}$ See summary of data for the Euro-Asia Division, 1985-1995, in appendix 3 . 


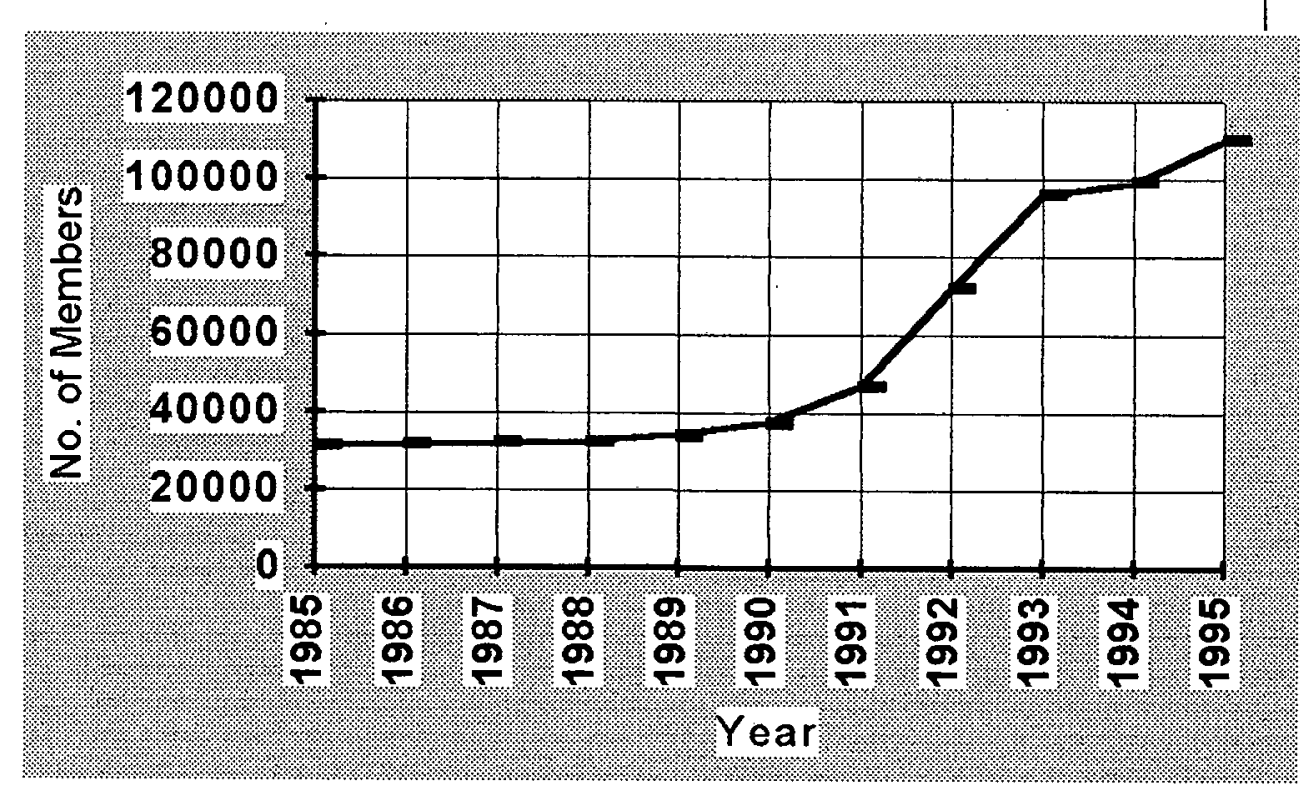

Fig. 1. Growth of the SDA church membership in the Euro-Asia Division during 1985-1995.

It is clearly seen from these figure and table that the SDA church in this Division has been growing throughout the whole decade. Membership increases were obviously higher during the second part of the decade: 1991-1995.

Evangelistic crusades, as mentioned above, have made their powerful contribution to church growth during this period. However, figure 1 also shows that since 1993 the rate of growth has slowed down. There are several reasons for this: a decline of interest in religion among the public, evangelistic activities of other denominations, a decline in the numbers of accessions, 1 transfers out of individual members moving abroad, as well as transfer of the ${ }^{1}$ See p. 51 , below. 
Baltic Conferences to the Trans-European Division, ${ }^{1}$ and the apostasy of new converts. ${ }^{2}$

Table 2 presents statistics on baptisms and professions of faith (accessions) during the 1985-1995 period. It also reveals the percentage of converts for the total membership. Figures 2 and 3 illustrate this data. The data reveal an interesting picture. In 1985, new believers composed about 5.5 percent of the total membership, which was the normal pattern until 1988. The year 1986 represents an exception, but the exception that year seems due to inaccurately presented statistics. Since 1989, the number of accessions began to grow and comprised about 14 percent of the total membership in 1990. The main reason for this growth in accessions was the increasing opportunities allowed by religious freedom.

In the next period, 1991-1995, the percentage of accessions was over or about 20 percent yearly except for 1992. This means that during that time, approximately one fourth of the total membership was made up of new converts (every other year). The year 1992 was the most successful year for public evangelism during this period.

\footnotetext{
${ }^{1}$ See p. 60 , below.

${ }^{2}$ see p. 63, below.
} 
Table 2

Accessions and Their Percentage for the Church Membership in 1985-1995

\begin{tabular}{lcc}
\hline Year & Accessions & Percentage \\
\hline 1985 & 1,718 & 5.49 \\
\hline 1986 & 232 & 0.73 \\
\hline 1987 & 1,553 & 4.84 \\
\hline 1988 & 1,662 & 5.13 \\
\hline 1989 & 3,179 & 9.31 \\
\hline 1990 & 5,030 & 13.45 \\
\hline 1991 & 11,340 & 24.32 \\
\hline 1992 & 28,295 & 39.37 \\
\hline 1993 & 28,241 & 29.45 \\
\hline 1994 & 22,260 & 22.49 \\
\hline 1995 & 21,368 & 19.44 \\
\hline & & \\
\hline
\end{tabular}

Source: Data are based on the 123rd Annual statistical Report 1985 (Washington, DC: General Conference of Seventhday Adventists, 1986), 24; the 124th Annual Statistical Report 1986, 24; the 125th Annual Statistical Report 1987 (1988), 24; the 126th Annual Statistical Report--1988 (Silver Spring, MD: General Conference of Seventh-day Adventists, 1989) 24 ; the 127th Annual Statistical Report-1989, 26; the 128the Annual Statistical Report--1990, 24; the 129th Annual Statistical Report--1991 (1992), 12; the 130th Annual Statistical Report--1992 (1993), 12; the 131st Annual Statistical Report--1993 (1994), 12; and the 132nd Annual Statistical Report--1994, 12. Data for 1995 are presented on the basis of information supplied by the EuroAsia Division. 


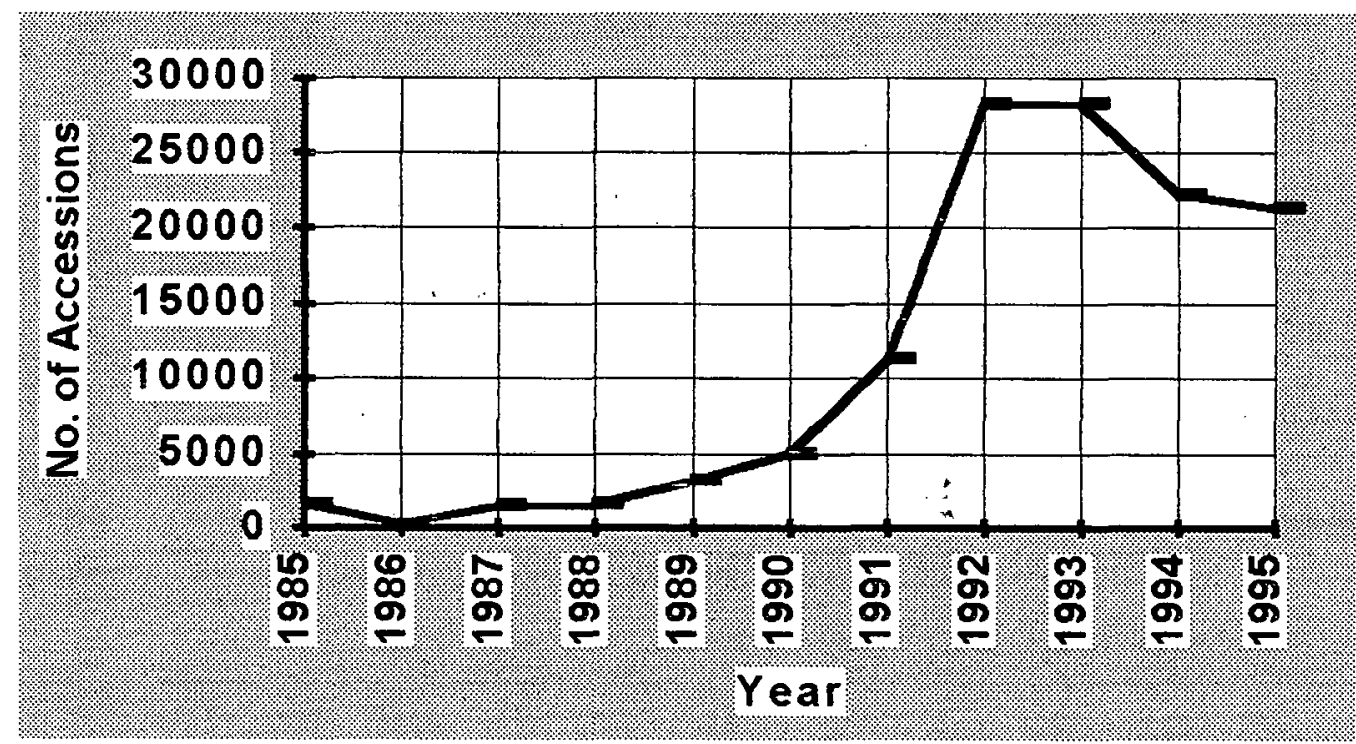

Fig. 2. Accessions in the Euro-Asia Division during the 1985-1995 period.

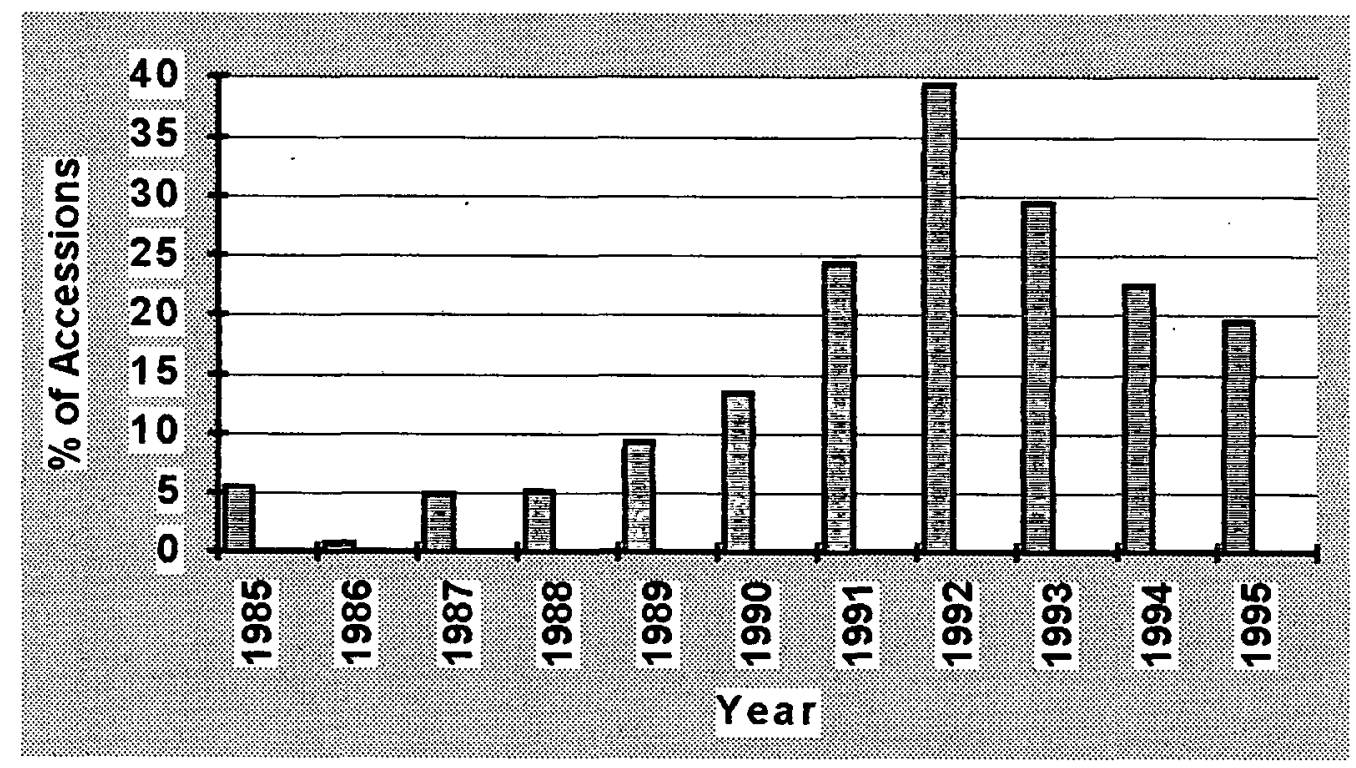

Fig. 3. The percentage of accessions of the church membership during 1985-1995. 
As was described above, interest towards evangelistic crusades was very high, evangelistic meetings were overcrowed, and, in addition, it seems that the largest number of campaigns were conducted that year. As a result, in 1992 about 40 percent (2/5) of the church membership was represented by people baptized that year.

The second most successful year was 1993, when new believers comprised about 30 percent $(1 / 3)$ of the total membership.

The total number of converts during 1985-1990 was 13,374 people. That is less than one third of the church membership in 1990. New members baptized during the 19911995 period constituted 111,504 people. This is eight times more than in the previous period and is very impressive in comparison with the total membership of $1995(109,889)$, because it surpasses it. One should take into consideration the apostasies, deaths, and transfers out of new believers in order to estimate the actual number of new members to the total membership in 1995 and to understand the discrepancy between the two figures. An analysis of this is presented later in this chapter.

Tables 1 and 2 do show yearly increases in membership. However, they do not reflect the growth each year in comparison with the previous one. Table 3 and 
figure 4 present the annual growth rates (AGR) for the decade being studied.

The AGR presents a clear picture of a dynamic, growing church in the Euro-Asia Division. As was seen from tables 1 and 2 , church membership increased every year. However, the data from table 3 show that although the AGR for every year in the decade was positive, there were some ups and downs in growth rates.

Table 3

Annual Growth Rates in 1985-1995

\begin{tabular}{lc}
\hline Year & Annual Growth Rate (8) \\
\hline 1985 & 0.98 \\
\hline 1986 & 1.19 \\
\hline 1987 & 1.19 \\
\hline 1988 & 1.04 \\
\hline 1989 & 5.41 \\
\hline 1990 & 9.5 \\
\hline 1991 & 24.7 \\
\hline 1992 & 54.16 \\
\hline 1993 & 33.4 \\
\hline 1994 & 3.21 \\
\hline 1995 & 11.0 \\
\hline
\end{tabular}




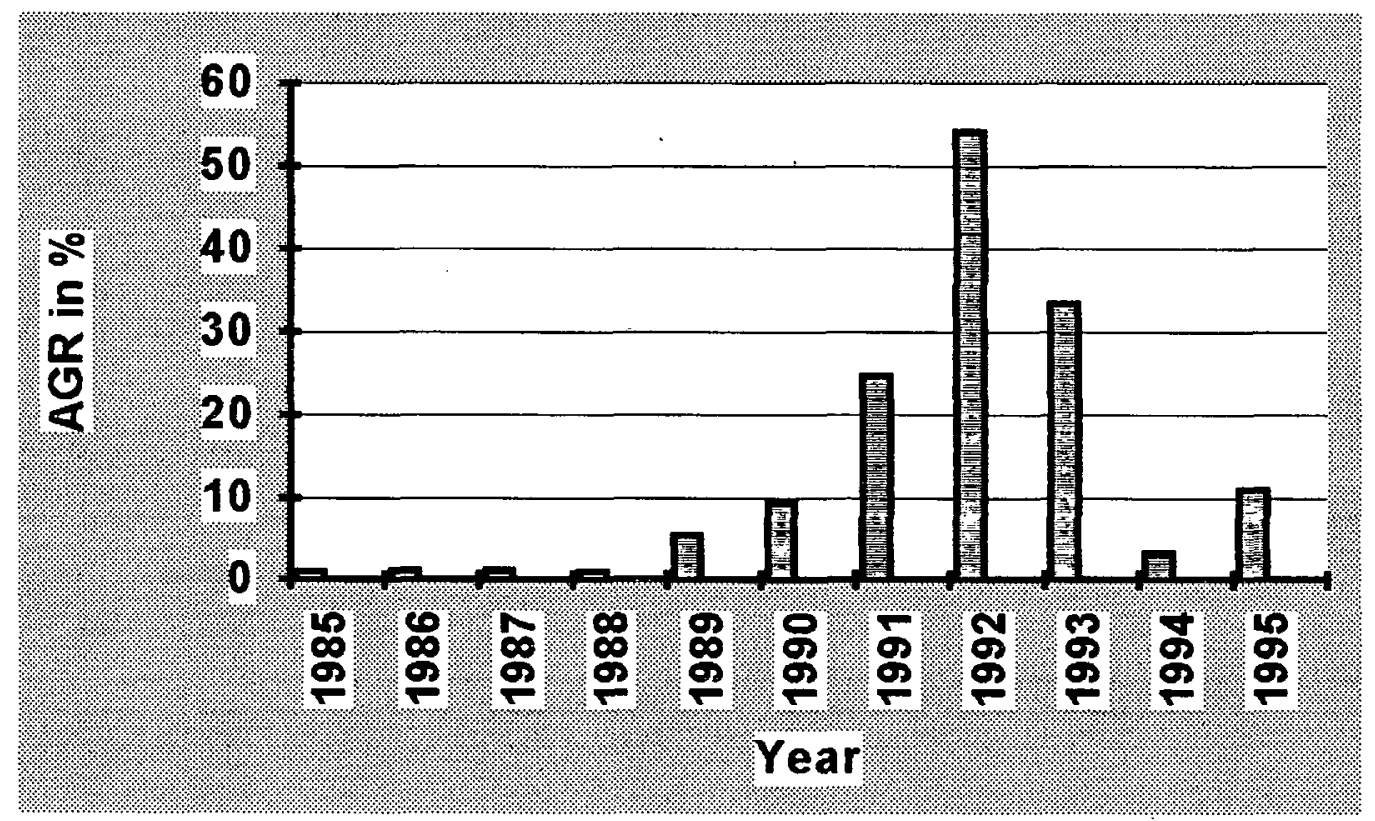

Fig. 4. Annual growth rates in 1985-1995.

During the period of 1985-1990, the most successful years were 1989 and 1990. This can be explained by the new opportunities for the church and growing numbers of accessions. In 1986 and 1987, the AGR was the same although the number of accessions in 1987 was several times more. The increase of apostasies, deaths, and transfers out may be possible reasons, although the data for the latter two are not available. In 1988, the AGR was lower than in the previous year, again, possibly because of apostacies, deaths, and transfers out.

In 1991-1995, the picture again is mixed. The largest percentage of growth in comparison with the previous year was in 1992. As mentioned above, 1992 was the most 
successful year in the era of public evangelism, and, in addition, the rate of apostasy that year was not high.

Alhough the number of accessions was almost the same in 1993 (see table 2), the AGR was lower due to increasing apostasy ${ }^{1}$ and transfers out. 2 In 1994, the AGR was the lowest during the evangelistic campaign period. The 1994 Division growth rate of 3.21 percent was even lower than the 1989 AGR of 5.41 percent in spite the many public crusades. Why? The major reasons for this are the largest (in this decade) number of apostasies ${ }^{3}$ and the largest number of transfers out (because of the transfer of the Baltic Conferences to the Trans-European Division). 4 The AGR in 1995 was higher than in 1994 but lower than in 1991, although the number of accessions in 1995 was almost twice as much as in 1991 (table 2). This can be explained by the following reasons: 1995 had the largest, number of deaths, the second largest number of apostasies, and the third largest number of transfers out. 5 Furthermore, it is easier to have high AGR when the number of total membership is small, and it takes
${ }^{1}$ see p. 63, below.
${ }^{2}$ See p. 60 , below.
${ }^{3}$ See p. 63, below.
${ }^{4}$ See p. 60, below.
${ }^{5}$ See p. 60,63 , below. 
much more effort to keep growing at a high AGR as total membership increases. 1

There is another standard measurement for church growth called decadal growth rate (DGR). To better understand the dynamics of church growth in this Division, decadal growth was calculated from three perspectives: for 1985-1990, for 1991-1995;, and for the whole decade. Figure 5 illustrates the results.

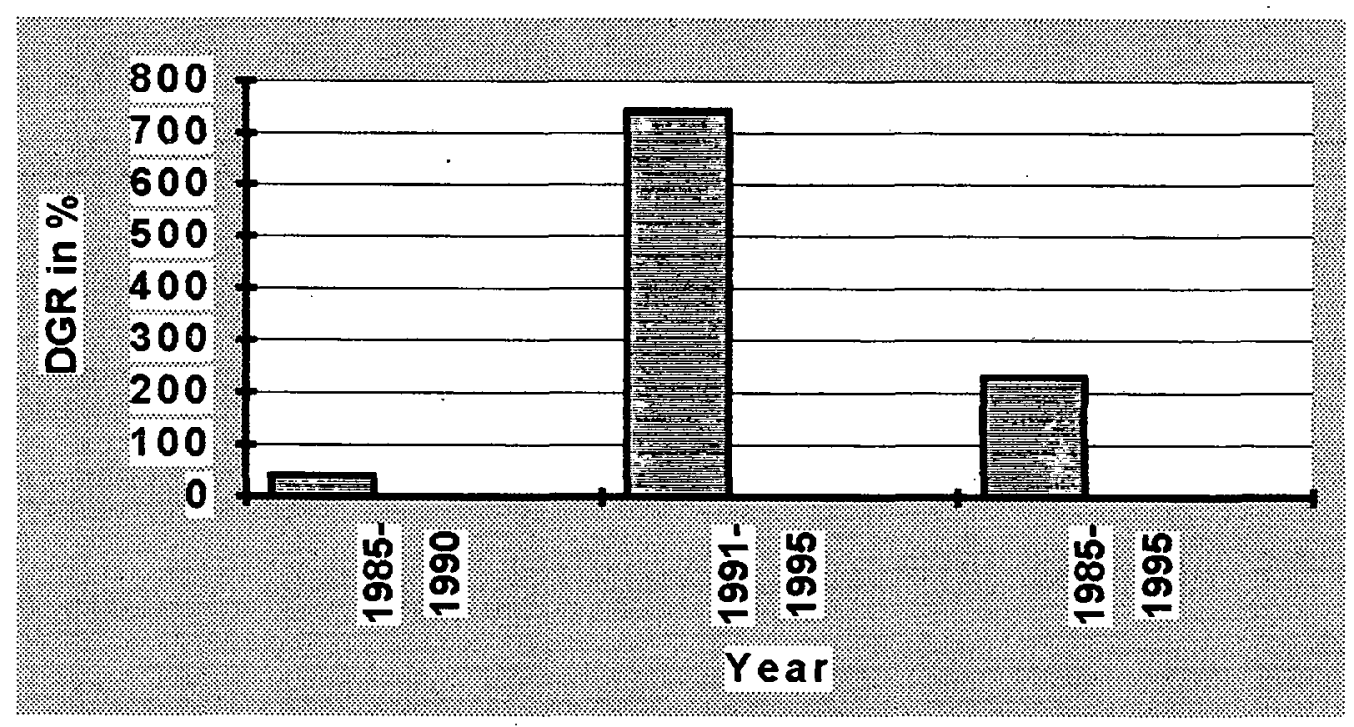

Fig. 5. Three perspectives on the decadal growth rate.

The DGR for the first period of $1985-1990$ was 41 percent. As a general rule, biological growth alone should equal 25 percent per decade, so a DGR of 41 percent for this

${ }^{1}$ See percentage of accessions in table 2 : although the number of accessions in 1995 was larger than in 1991, the percentage of accessions for the church membership was smaller. 
period is fair growth. ${ }^{1}$ This means that if during the whole decade the church had continue to grow at approximately the same rate as it did during 1985-1990, the DGR for the whole period would be about 41 percent, and the total membership would have only reached 44,140 .

However, the DGR for the second period of 1991-1995 was 743 percent. This is incredible growth! ${ }^{2}$ This means that if the Division had experienced similar growth since 1985 with similar net gains during $1985-1990$ as in 19911995, the DGR for the decade would have been 743 percent with the total membership in 1995263,901 .

The DGR for the whole decade was 228.6 percent. This is excellent growth. 3 obviously, the emphasis on public evangelism helped the church grow at this excellent rate.

Never before in the history of the church in this part of the world have there been more than 10,000 conversions in a year. However, alongside this success, a dangerous trend of nominality and apostasy among the new

${ }^{1}$ C. Peter Wagner, Strategies for Church Growth (Ventura, CA: Regal Books, 1987), 162, defines decadal growth rates in the following way: 25 percent DGR--marginal growth; 50 percent DGR--fair growth; 100 percent DGR--good growth; 200 percent DGR--excellent growth; 300 percent DGR-outstanding growth; 500 percent DGR--incredible growth.

${ }^{2}$ Ibid.

3 Ibid. 
members has appeared, as is discussed in the next subsection.

\section{Three Sources of the Decrease \\ of Membership}

Generally, a combination of three major factors result in a decrease in membership: death, transfers, and apostasy.

Table 4 and figure 6 present the numbers for deaths and transfers out. Data are only available since 1988. As table 4 shows, the average number of deaths and transfers out during this period comprised less than 2,000 per year until 1992, and fewer than 2,500 in 1993 and 1995.

The huge number of transfers out in 1994 is explained by the transfer of the Estonian and Latvian Conferences (total membership of 5,597, where 3,410 are represented by members converted since 1991) to the Trans-European

Division. 1 Table 4 demonstrates the necessity to win about 2,500 members each year just to replace those dying and transfering out.

There has also been a lot of local transition within the Division.

\footnotetext{
${ }^{1}$ See p. 11-12, above.
} 
Table 4

Death and Transfers Out

\begin{tabular}{|c|c|c|c|}
\hline Year & Death & Transfers Out & Total \\
\hline 1988 & 860 & 192 & 1,052 \\
\hline 1989 & 962 & 64 & 1,026 \\
\hline 1990 & 937 & 525 & 1,462 \\
\hline 1991 & 1,241 & 402 & 1,643 \\
\hline 1992 & 1,092 & 839 & 1,931 \\
\hline 1993 & 1,122 & 1,279 & $2, \overline{401}$ \\
\hline 1994 & 1,243 & 7,039 & 8,282 \\
\hline 1995 & 1,398 & 880 & 2,278 \\
\hline
\end{tabular}

Source: Figures for deaths for 1988-1992 are taken from "Statistical Report Prepared by the Office of Archives and Statistics for the Annual Council of the General Conference Committee, Bangalore, India, October 5-11, 1993" in Reports (Moscow: The Euro-Asia Division, 1993), 4. Transfers out of the Division for these years are calculated by the exclusion of deaths and apostasies from the total number of decrease. Figures for 1993-1995 are given on the basis of information in: "Godichnij Otchet Secretarya EAD" ("Annual Report of the Secretary of the Euro-Asia Division") in ibid., 3; "Otchet Secretarya EAO" ("Report of the Secretary of the Euro-Asia Division") in Reports (Moscow: The Euro-Asia Division, 1994), 15; "Otchet Secretarya" ("Report of the Secretary") in Reports $(1995), 10$. 


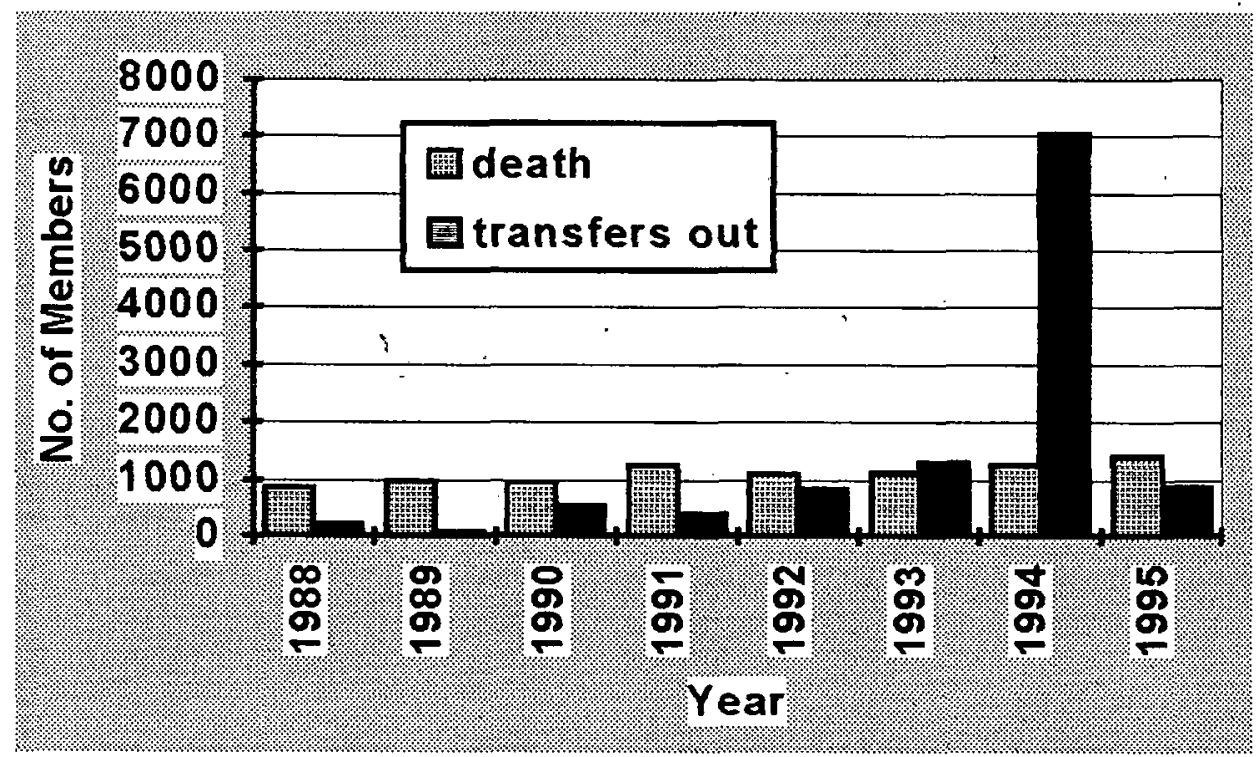

Fig. 6. Death and transfers out.

The disintegration of the former Soviet Union into independent states, the political and economical instability, and national enmity are some of the reasons why many of the SDA members in this Division have changed their places of residence during the last few years. To illustrate this transition, 3,258 members changed their places of residence inside the Division in 1993.1 The next year their number grew 6.5 times and constituted $21,214.2$ In 1995, 4,655 Adventists moved to other areas. 3 Thus, in

1"Godichnij Otchet Secretarya EAD" ("Annual. Report of the Secretary of the Euro-Asia Division"), 3.

2 "Otchet Secretarya EAO" ("Report of the secretary of the Euro-Asia Division"), 15.

3"Otchet Secretarya" ("Report of the Secretary"), 10. 
three years, 29,127 members transferred their membership from one Adventist church to another because of a move to a new place of residence.

The third source of membership decrease is apostasy. Table 5 presents the number of apostatized and missing members in the Division from 1985-1995. It also lists apostasies as a percentage of accessions and apostasies as a percentage of total membership. Figures 7,8 , and 9 illustrate these data.

The highest percentage of apostasy was in 1994 with almost half of the number of 1994 accessions leaving the church. However, the problem did not start in 1994. The potential for apostasy was there from the very beginning of the emphasis on public evangelism. Short-term baptism preparations, inadequate number of pastors, absence of regular personal contacts, and lack of thorough follow-up after crusades--all these factors definitely influenced the high rate of apostasy.

The situation for new believers has often been even more complicated because of tension with their families, broken friendships, trouble because of Sabbath keeping, and the demands of the new Christian lifestyle. Newcomers frequently were left by themselves without any support from their congregation since, in many churches, 50 percent, 75 percent, or even 90 percent of the membership was comprised of new members. 
Table 5

Apostasy and Its Percentage of the Accessions and of the Total Membership

\begin{tabular}{lcll}
\hline Year & $\begin{array}{l}\text { Total } \\
\text { Apostasies }\end{array}$ & $\begin{array}{l}\text { Apostasies as } \\
\text { a Percentage } \\
\text { of Accessions }\end{array}$ & $\begin{array}{l}\text { Apostasies as } \\
\text { a Percentage } \\
\text { of Membership }\end{array}$ \\
\hline 1985 & 300 & 17.46 & 0.96 \\
\hline 1986 & 9 & 3.88 & 0.03 \\
\hline 1987 & 293 & 18.86 & 0.91 \\
\hline 1988 & 275 & 16.54 & 0.85 \\
\hline 1989 & 399 & 12.55 & 1.17 \\
\hline 1990 & 326 & 6.48 & 0.87 \\
\hline 1991 & 462 & 4.07 & 0.99 \\
\hline 1992 & 1,114 & 3.94 & 1.55 \\
\hline 1993 & 1,792 & 6.34 & 1.87 \\
\hline 1994 & 10,900 & 48.97 & 11.0 \\
\hline 1995 & 7,977 & 34.52 & 7.26 \\
\hline
\end{tabular}

Source: Data are based on the 123rd Annual Statistical Report 1985 (Washington, DC: General Conference of Seventhday Adventists, 1985), 24; the 124th Annual Statistical Report 1986, 24; the 125th Annual Statistical Report 1987, 24; the 126th Annual Statistical Report--1988 (Silver Spring, MD: General Conference of Seventh-day Adventists, 1989) 24; the 127th Annual Statistical Report--1989, 26; the 128the Annual Statistical Report--1990, 24; the 129th Annual Statistical Report--1991, 12; the 130th Annual Statistical Report--1992, 12; the 131st Annual Statistical Report--1993, 12: and the 132nd Annual Statistical Report--1994, 12 . Data for 1995 are presented on the basis of information supplied by the Euro-Asia Division. 


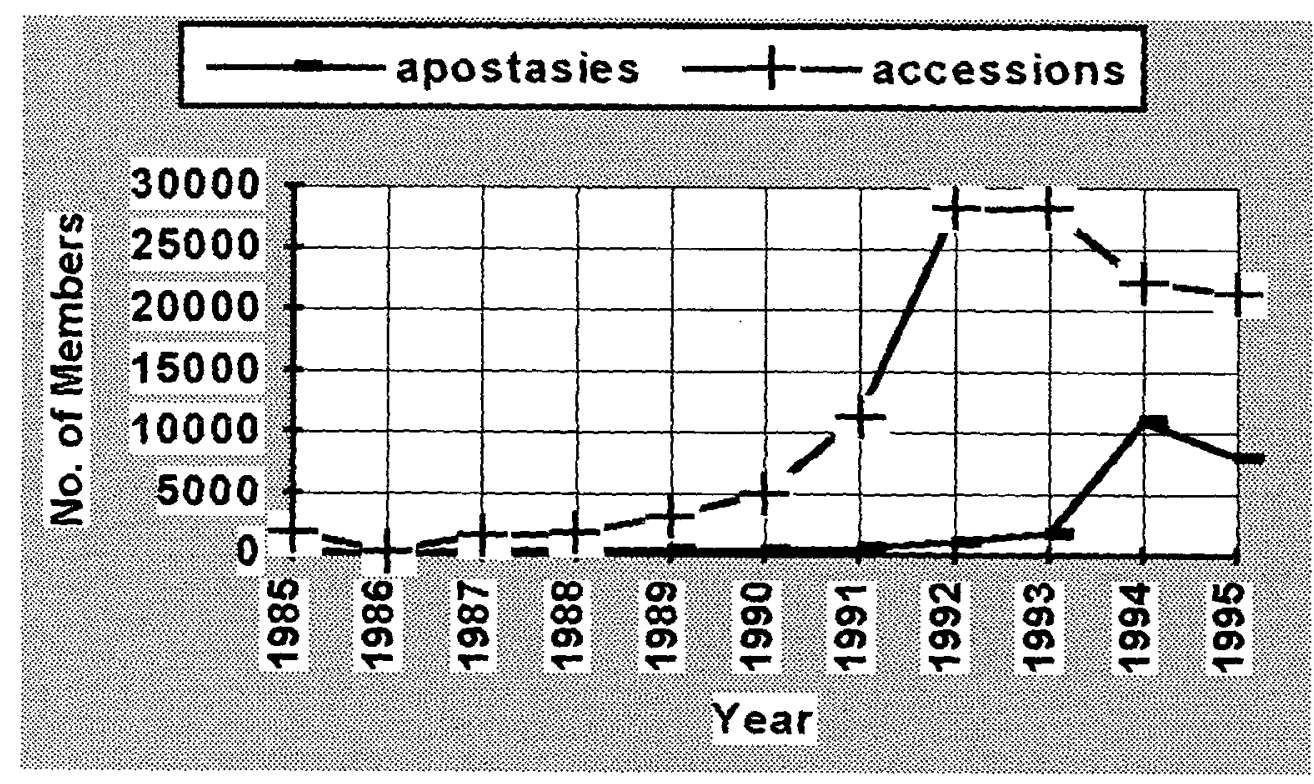

Fig. 7. Apostasy and accessions during the 1985-1995 period.

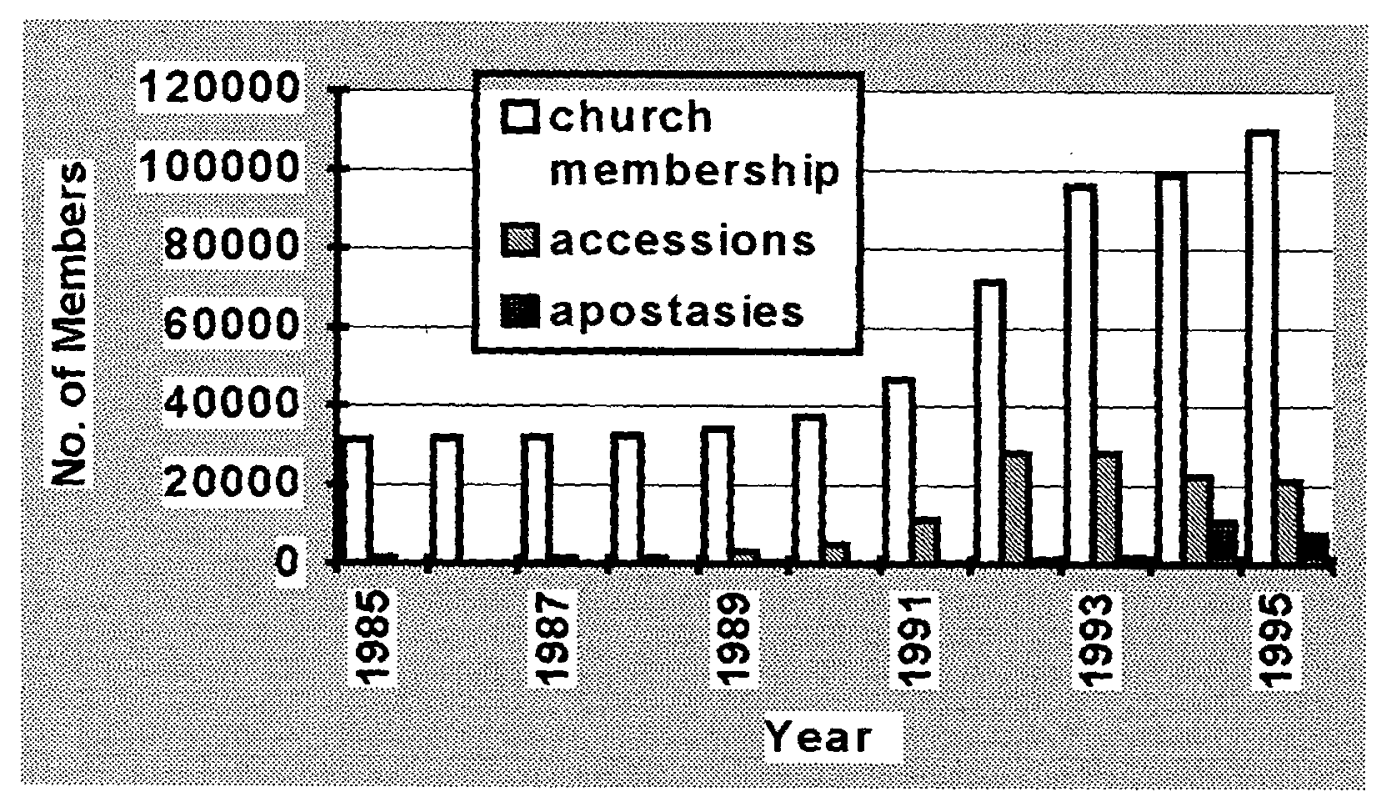

Fig. 8. Church membership, accessions, and apostasy. 


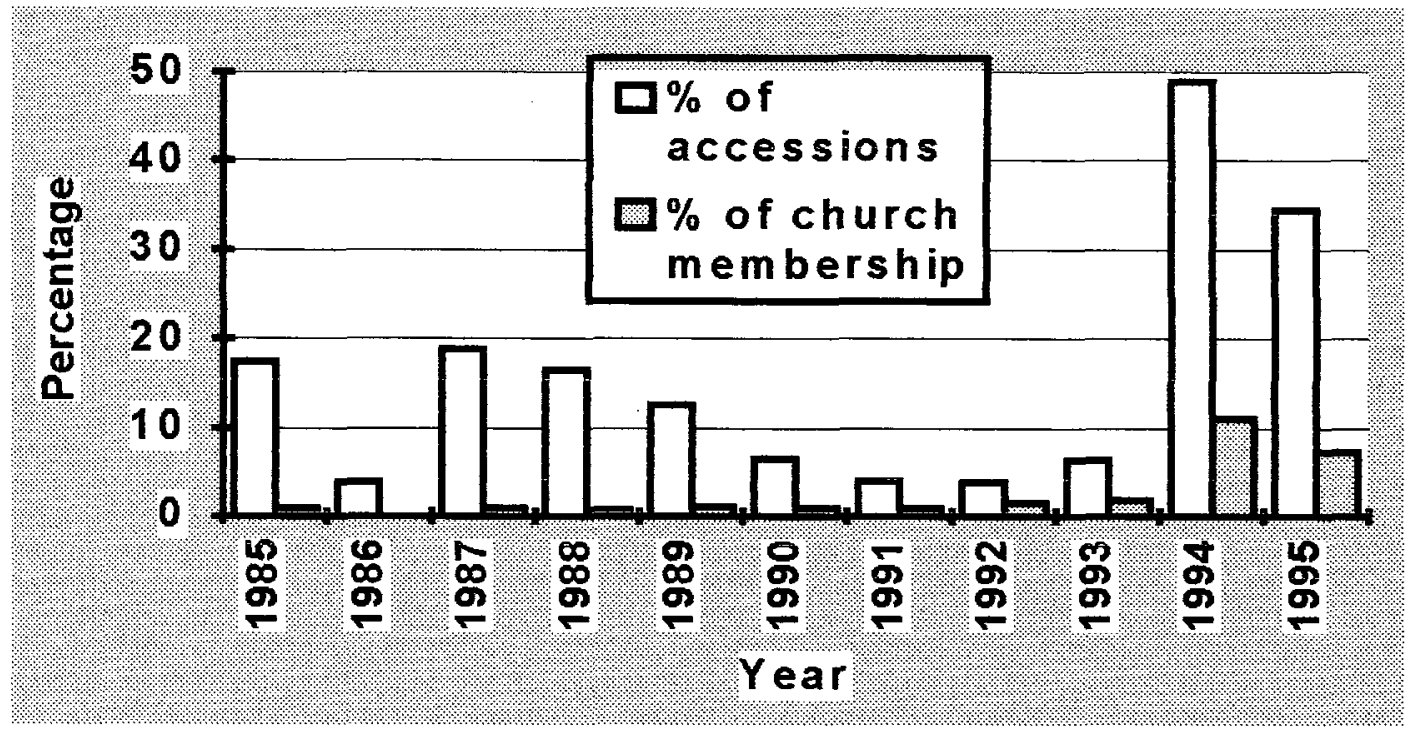

Fig. 9. Apostasies as a percentage of accessions and church membership.

In addition, in the minds of many Russian people the baptism ritual is often connected simply with the act of forgiveness of sins without any sense of obligation to the church. Because of these factors many new converts find it quite easy to drop out from their new church families.

The 1994 apostasy rate does not represent only converts from that particular year, but includes any member or new convert who drops out of fellowship. It is also natural to expect a higher rate of apostasy two or three years after the beginning of the period marked by evangelistic crusades and high membership increases rather than in the first year of this period (figure 7 ).

The total number of apostasies for the decade was 23,847. Sadly enough, apostasies during the public 
evangelism period (1991-1995) totaled 22,245. Obviously, some members were converted before 1991 who left the church during the period from 1991-1995. However, it seems that the majority of the 22,245 were new believers who remained in fellowship for only a short time.

As mentioned above, 111,504 people have been converted since 1991. Let us assume that one half of those who died and transfered out were new members, we end up with $8,879.1$ If we further assume that new members comprised 75 percent of apostasies and missing during the same period, we have 16,684 . If we would subtract the above two figures from the 111,504 converted since 1991, the number of new members presently attending church would be reduced to 85,941. This means that even with the high apostasy rate, there are approximately 85,941 members out of 109,889 who came to the Adventist church during the last five years. Although this is an approximate number, it still a very big number: about 78 percent of the total membership are recent converts (figure 10). The proportion is too significant to ignore. Something has to be done for this group of people.

${ }^{1}$ It is a number composed of half of the transfers out and deaths of 1991, 1992, 1993, 1995 plus 3,410 new converts who transferred out from the Baltic Conferences plus 721-one half of other transfers out of 1994 plus $621.5--$ half of deaths in 1994. 


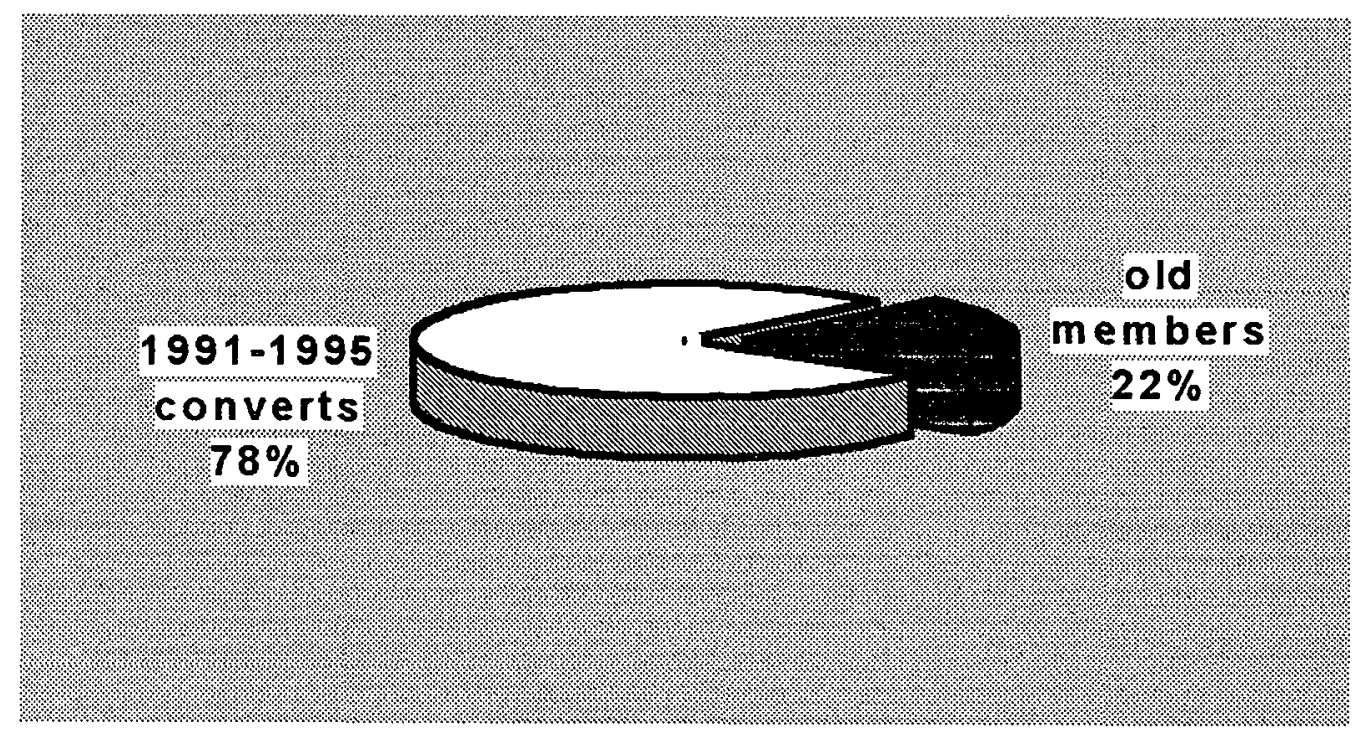

Fig. 10. Percentage of 1991-1995 converts in the total membership of 1995 .

Membership totals can be decreased in three ways that impact the yearly membership net gains. ${ }^{1}$ Table 6 shows both the yearly net gains since 1988 and net gains as a percentage of accessions. Figure 11 gives a comparative picture of these two categories.

As seen from table 6 and figure 11,1988 and 1994 had the lowest net gains. In 1989. and 1995 almost 50 percent of the accessions were lost through death, apostasy, and transfer out. Tables 2, 4, and 5 shed some light on this matter. In 1988, deaths and transfers out comprised 63 percent of the accessions, and apostasy took another 17 percent.

${ }^{1}$ Net gain is the number of real gain during the year. It represents the difference between the accessions of that year and apostasies, missing, deaths, and transfers out. 


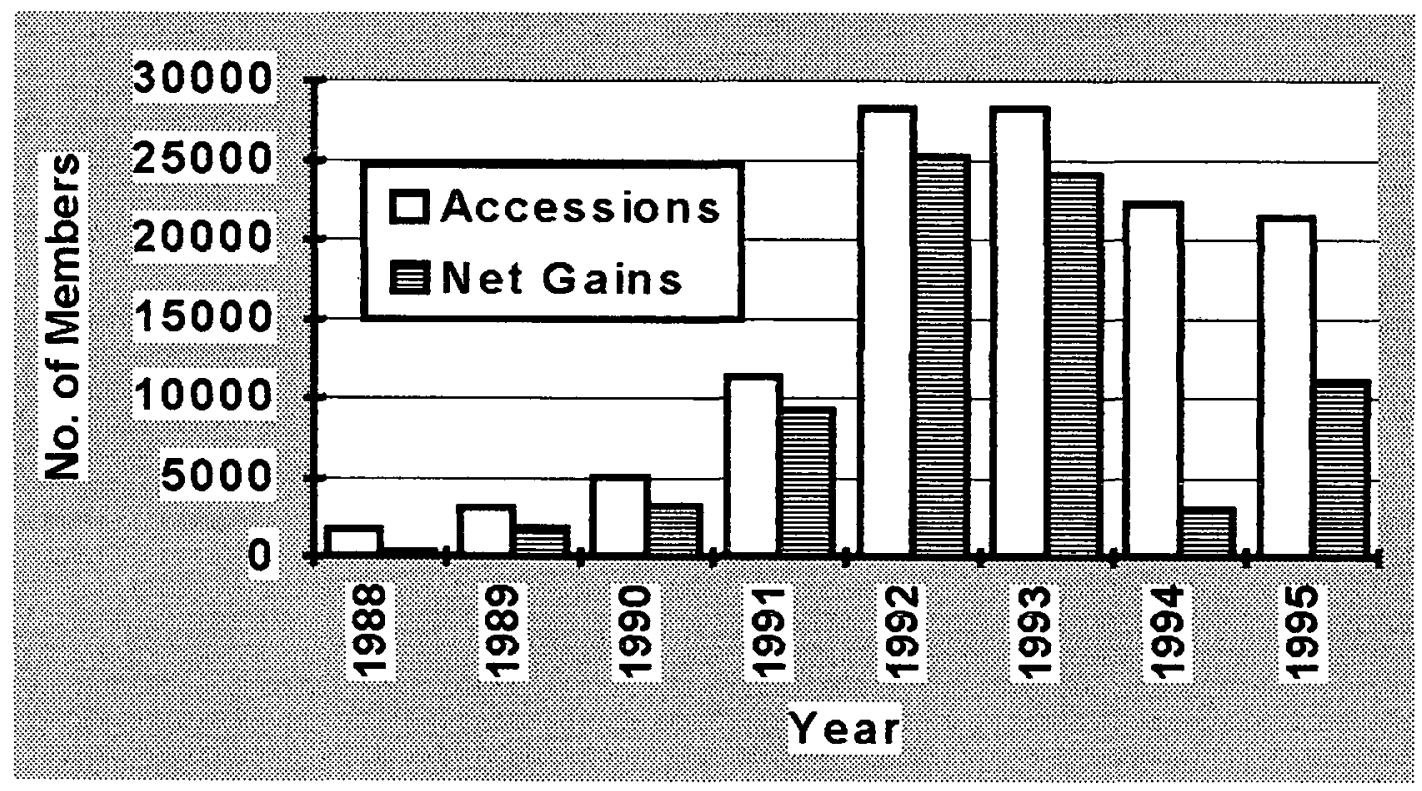

Fig. 11. Net gains and their proportion to accessions.

Table 6

Net Gains and Net Gains as a Percentage of Accessions

\begin{tabular}{lcl}
\hline Year & Net Galns & Percentage \\
\hline 1988 & 335 & 20.2 \\
\hline 1989 & 1,754 & 55.2 \\
\hline 1990 & 3,242 & 64.4 \\
\hline 1991 & 9,235 & 81.4 \\
\hline 1992 & 25,250 & 89.2 \\
\hline 1993 & 24,048 & 85.1 \\
\hline 1994 & 3,078 & 13.8 \\
\hline 1995 & 11,113 & 52.0 \\
\hline
\end{tabular}


In 1989, net gains increased since there was almost twice as many accessions that year as in 1988 . The rate of apostasy was also lower (about 13 percent of accessions), and the number of deaths and transfers out was approximately the same. In 1994, the number of accessions was lower than in 1992 and 1993, but the rate of apostasy (about 49 percent of accessions) and transfers out was the largest for the whole decade. In 1995, net gains comprise only about half of the accessions; apostasy took away about 35 percent and the rest was lost through deaths and transfers out. Thus, although 1991-1995 was a period of public evangelism with large numbers of accessions, data for the last two last years show that there are significant problems the Division must deal with. There is a need for a strategy that can help to follow up new believers, prevent apostasies, and supply needed pastoral care caused by an inadequate number of pastors and not enough church buildings. In the next section we will look specifically at these last two factors.

\section{Infrastructure Weaknesses in the Euro-Asia Division: Inadequate Number of Pastors and Church Buildings}

Pastors have always been needed in the vast territory of the Division. Since 1991, the rapid growth of membership made this an even more desperate need. Table 7 shows the 
number of ordained and licensed ministers since $1986,{ }^{1}$ and figure 12 presents a comparison between numbers of congregations and pastors in the same period.

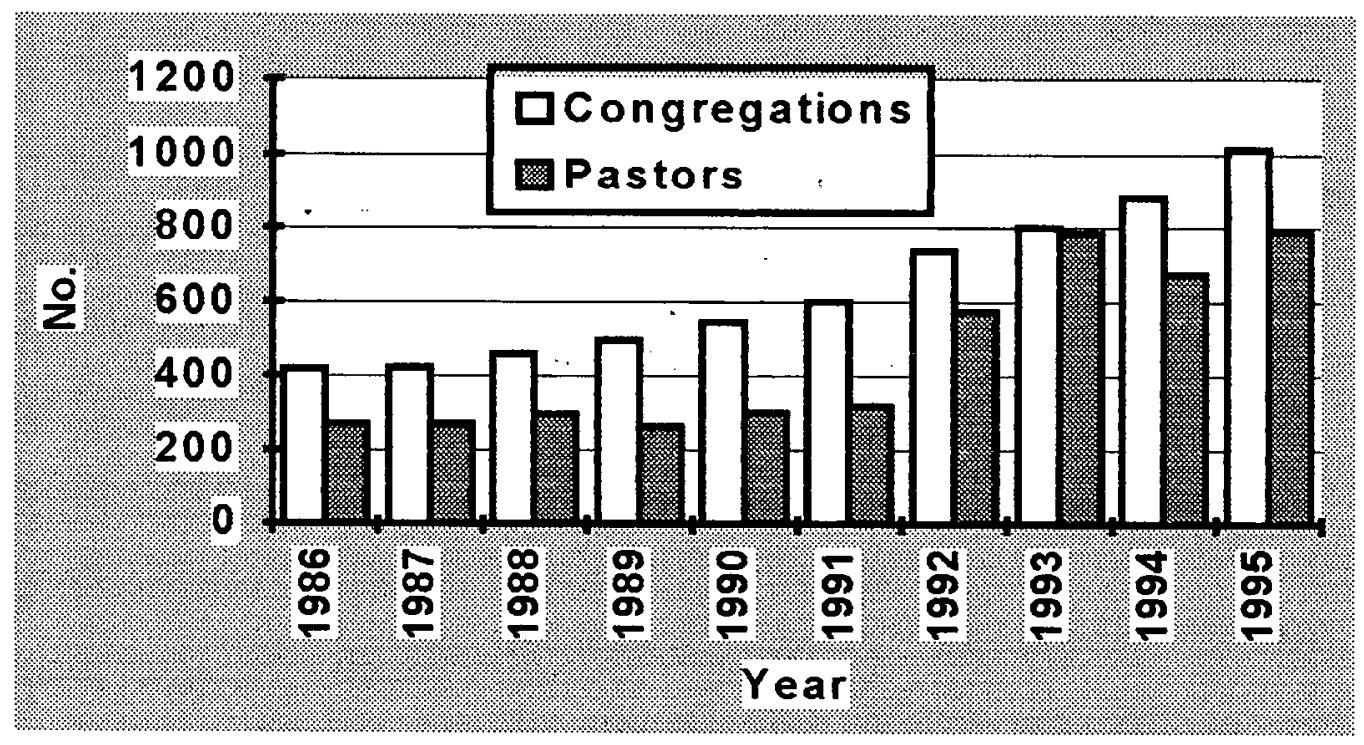

Fig. 12. A comparison between numbers of congregations and pastors during 1986-1995.

Table 7 shows that in the first period (1986-1990) the number of ordained ministers was greater than that of the licensed ones. However, when the Euro-Asia Division was organized with additional unions and conferences, many of the ordained ministers were placed in administrative positions. An additional challenge was created by the rapid increase in membership from 1991-1995.

\footnotetext{
$1_{\text {The data for }} 1985$ are not accurate. Compare the 122nd Annual Statistical Report 1984, 23; the 123rd Annual Statistical Report 1985, 25; and the 124th Annual Statistical Report 1986, 25.
} 
Table 7

Ordained and Licensed Ministers

\begin{tabular}{llcl}
\hline Year & Ordalned & Licensed & Total \\
\hline 1986 & 188 & 83 & 271 \\
\hline 1987 & $188+$ & $83+$ & $271+$ \\
\hline 1988 & 203 & 93 & 296 \\
\hline 1989 & 199 & 64 & 263 \\
\hline 1990 & 210 & 91 & 301 \\
\hline 1991 & 229 & $91+$ & $320+$ \\
\hline 1992 & 269 & 304 & 573 \\
\hline 1993 & 267 & 518 & 675 \\
\hline 1994 & 276 & 399 & 790 \\
\hline 1995 & 291 & 499 & \\
\hline
\end{tabular}

Source: Data are based on the 124th Annual Statistical Report 1986, 25; the 125th Annual Statistical Report 1987, 25; the 126th Annual Statistical Report--1988, 25; the 127th Annual Statistical Report--1989, 27; the 128th Annual Statistical Report--1990, 13; the 129th Annual Statistical Report--1991, 13. Accurate data for ordained and licensed ministers for 1987 and licensed for 1991 are not available. Data for 1992-1994 are presented on the basis of the 130th Annual Statistical Report--1992, 13, the 131st Annual Statistical Report--1993, 13, and the 132nd Annual Statistical Report--1994, 13, but with some corrections based on "Godichnij Otchet Secretarya EAD" ("Annual Report of the Secretary of the Euro-Asia Division"), 2; "Otchet Secretarya EAO" ("Report of the Secretary of the Euro-Asia Division," 10; and "Otchet Secretarya" ("Report of the Secretary"), 5. Division workers are not included in the table, however, ministers holding administrative positions in the fields are included. Thus, in reality the number of pastors actively involved in pastoral work is even smaller than presented in the table. 
The lack of ministers for each congregation was partially solved by increasing the number of licensed ministers. As seen from table 7, in the second period of the decade the number of licensed ministers surpassed the number of ordained ministers.

Additional investigation is needed to find out the reasons for the decline in the number of ministers in 1989 and in 1994. It seems that the statistics presented in the 127 th Annual Statistical Report--1989 were not complete since there was no distribution of figures among the different parts of the Division. ${ }^{1}$ Possible reasons for the decline of ministers in 1994 might be the transfer of the Baltic Conferences to the Trans-European Division, other transfers out, changes in careers, and also inaccurate statistics in the reports. Thus, for example, a comparison of the 131st Annual Statistical Report--1993 and the 132nd Annual Statistical Report--1994 shows that in 1993 there were no credentialed missionaries in the Ukraine and 208 licensed ministers; in 1994 there were 110 credentialed missionaries and 136 licensed ministers. ${ }^{2}$

Figure 12 presents the challenge of the inadequate number of ministers in this Division. In 1994, there were

\footnotetext{
1 127th Annual Statistical Report--1989, 27.

2131st Annual Statistical Report--1993, 13; 132nd Annual statistical Report--1994, 13.
} 
at least 200 congregations in the Division without a minister and in 1995 the picture was not much better.

Another obvious need that accompanied the fantastic membership growth in the Division was the need for church buildings accompanied the growth of the Division. Table 8 presents the available statistics on the number of congregations, church buildings, and congregations without church buildings throughout the 1985-1995 period. Figures 13 and 14 illustrate the data.

The distribution of churches vary greatly within the Division territory. In some places members meet together in rented public halls while in others they have church buildings. For example, the number of congregations in Moscow changed from one to fourteen during this period, ${ }^{1}$ but none of them has its own church building.

The situation in the Trans-Siberian Conference in 1992, where "of the 40 congregations, only five or six" had "prayer houses," 2 was not an exception. "In the Russian Union, for instance," in 1993 there were "about 190 church groups, but only 10 have their own buildings." 3

\footnotetext{
${ }^{1}$ Wilson, 5 .

2 Johnsson, "Snapshots of Russia and the Ukraine," 8. ${ }^{3}$ Butler and Koolik, 24.
} 
Table 8

Number of Congregations with and without Church Buildings

\begin{tabular}{lccc}
\hline Year & Congregations & $\begin{array}{l}\text { With Church } \\
\text { Buildings }\end{array}$ & $\begin{array}{l}\text { Without Church } \\
\text { Buildings }\end{array}$ \\
\hline 1985 & 414 & -- & -- \\
\hline 1986 & 418 & -- & -- \\
\hline 1987 & 423 & -- & -- \\
\hline 1988 & 460 & -- & -- \\
\hline 1989 & 498 & -- & 340 \\
\hline 1990 & 546 & 206 & 408 \\
\hline 1991 & 601 & 193 & 428 \\
\hline 1992 & 738 & 310 & 320 \\
\hline 1993 & 800 & 480 & 526 \\
\hline 1994 & 883 & 357 & 544 \\
\hline 1995 & 1,017 & 473 & \\
\hline & & & \\
\hline
\end{tabular}

Source: Data are based on the 123rd Annual Statistical Report 1985 (Washington, DC: General Conference of Seventhday Adventists, 1985), 24-25; the 124th Annual Statistical Report 1986, 24-25; the 125th Annual Statistical Report 1987, 24-25; the 126th Annual Statistical Report--1988 (Silver Spring, MD: General Conference of Seventh-day Adventists, 1989) 24-25; the 127th Annual Statistical Report--1989, 26-27; the 128the Annual Statistical Report-1990, 24-25; the 129th Annual Statistical Report--1991, 12; the 130th Annual Statistical Report--1992, 12-13; the 131st Annual Statistical Report--1993, 12-13; and the 132nd Annual Statistical Report--1994, 12-13. Data for 1995 are presented on the basis of information supplied by the EuroAsia Division. 


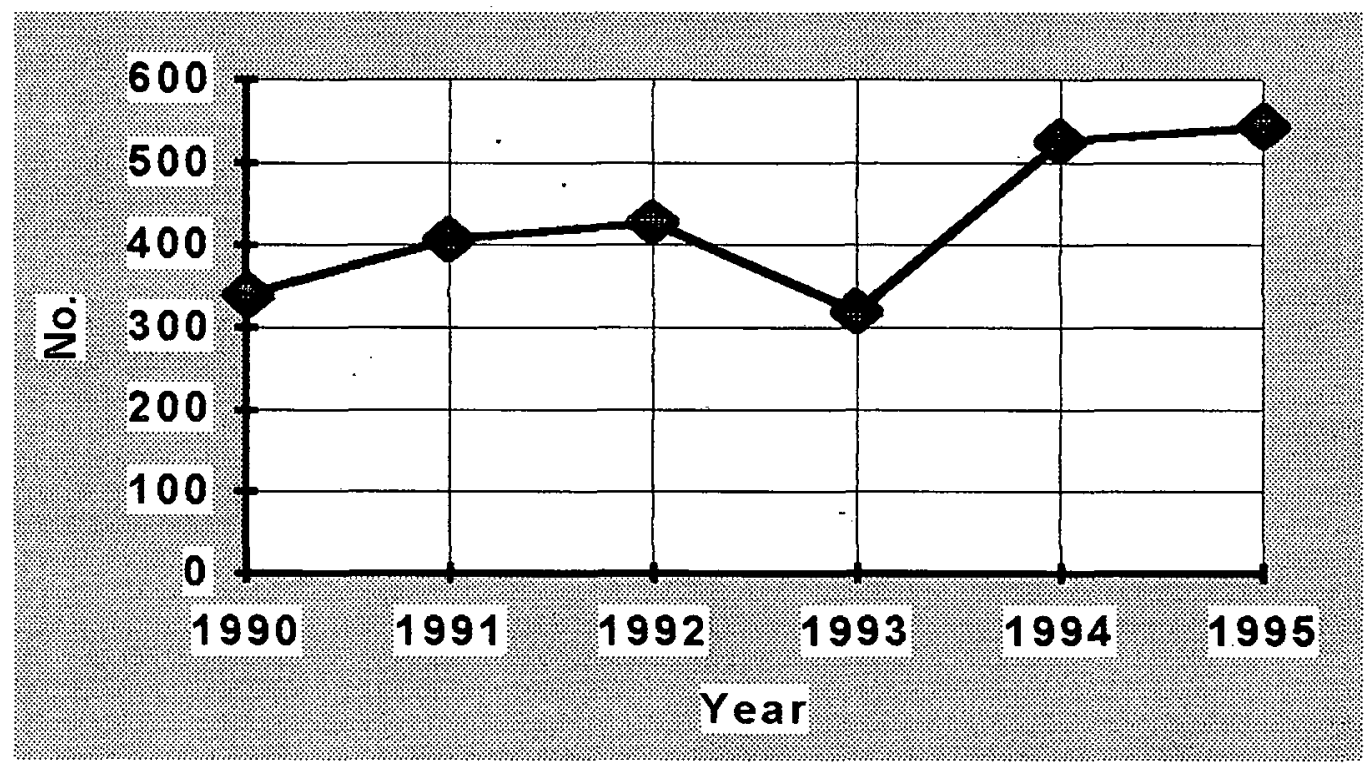

Fig. 13. Number of congregations without church buildings in the 1990-1995 period.

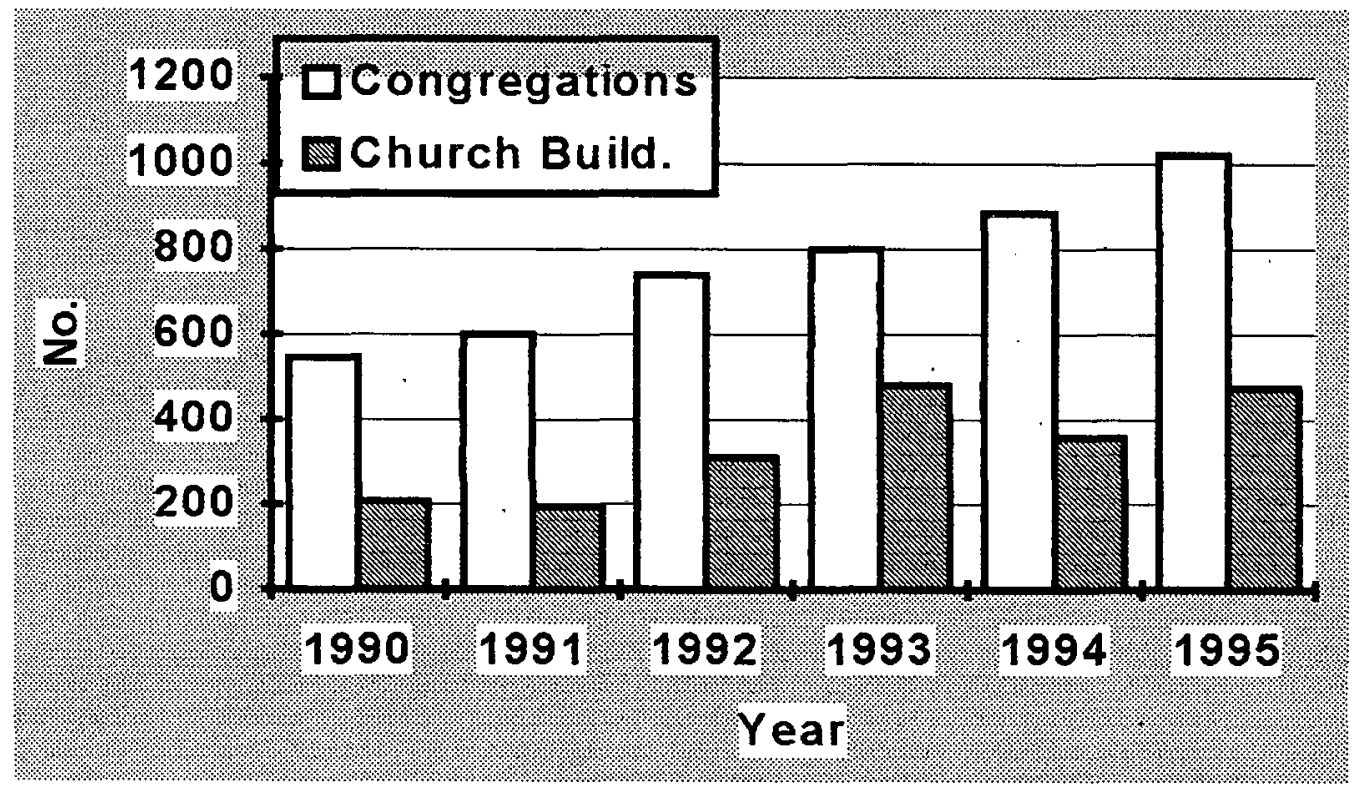

Fig. 14. Number of congregations and church buildings in the 1990-1995 period. 
In the first half of 1992, W. G. Johnsson wrote: "Our existing churches are already full to overflowing; how can we accommodate the thousands of new believers?" 1

Although "more than 100 church buildings are currently under construction," as R. Wilcox, GC presidential assistant for Soviet Affairs, reported in 1992,2 the need of "at least 240 new churches" was pointed out by R. Folkenberg. 3 To meet these challenges the Development and Construction Service was formed under the supervision of Peter Koolik, "a volunteer builder from Australia." 4 As he reported in 1993, "Evangelism in Russia and the entire division has grown by leaps and bounds during the past few years. Church construction has not been able to keep up with it." 5 Although public "halls, cinemas, and rented or leased buildings" 6 were a solution, there were some inconveniences. "Sometimes they have to move on every two or three months when their lease expires or their rent goes up. They haven't got Sabbath school facilities for children." 7 He

\footnotetext{
1Johnsson, "The Risen Christ over Red Square," 13.

2 "Newsbreak: Euro-Asia Carries on Amid Historic Changes," Adventist Review, January 23, 1992, 6.

3 Johnsson, "The Risen Christ over Red Square," 14.

${ }^{4}$ Wilson, 5 .

${ }^{5}$ Butler and Koolik, 24.

${ }^{6}$ Ibid.

7 Ibid.
} 
concludes that "probably no less than 500 churches need to be built in the next few years to keep up with the demand." 1 Thus, the church in Russia recognized the challenge and tried to meet it. For the 1992-1994 period only, "some 350 churches were constructed or renovated." 2 Figure 13 shows a decline in 1993 for the number of congregations that needed church buildings. The formation of the Construction Service and the many church building projects throughout the Division began to have an impact. However, it was not enough. As table 8 and figure 14 illustrate, in 1995 more than half of the congregations still did not have their own church buildings.

In summary, we can clearly state that the Euro-Asia Division is experiencing a high rate of apostasy, is lacking adequate numbers of pastors, and is lacking enough church buildings.

\section{Comparative Analysis of Church Growth in the Euro-Asia Division Unions and Attached Fields in 1991-1995}

This section presents some statistics on church growth in the different parts of the Euro-Asia Division. The analysis is limited to the second period of the decade (1991-1995) in order to investigate the growth the public

\footnotetext{
$1_{\text {Ibid. }} 25$.

${ }^{2}$ wilson, 5 .
} 
evangelistic campaigns produced. One complicating factor is that during this period union boundaries were moved, thereby making it difficult to do an adequate job of comparing data for some fields. For the most part, the section deals with the four Union Conferences, one Union Mission, and two attached Fields. In some cases, the information is presented in view of the five parts of the Division. In such instances, the East Russian Union Mission and the West Russian Union Conference are combined, and the TransCaucasus Field is united with the Southern Union Conference. It is not easy to determine what part of the EuroAsia Division has more advantages in comparison with the others. The western section is more heavily populated and developed while the eastern part has more unentered territory. While the northern part is dominated by the Orthodox church, the south represents diverse multicultural and multireligious states, with many of the indigenous population being followers of Islam.

The distribution of the population among the Unions and attached Fields is also unequal. Table 9 gives the percentages of the population in the different parts of the Division as of summer of 1995. Figure 15 reflects the situation. Figure 16 shows the Seventh-day Adventist presence $(0.04 \%)$ as compared to the population of the EuroAsia Division. 
Table 9

The Percentage of the Population in the Euro-Asia Division Unions and Attached Fields

\begin{tabular}{lc}
\hline Parts of the Division & Percentage \\
\hline WRUC & 40.5 \\
\hline ERUM & 11.0 \\
\hline UUC & 18.0 \\
\hline MUC & 1.5 \\
\hline SUC & 19.0 \\
\hline TCM & 5.8 \\
\hline BC & 3.6 \\
\hline
\end{tabular}

WRUC = the West Russian Union Conference; ERUM = the East Russian Union Mission; UUC = the Ukrainian Union Conference; MUC = the Moldova Union Conference; SUC = the Southern Union Conference; $\mathrm{TCM}=$ the Trans-Caucasus Mission Field; $\mathrm{BC}=$ the Belarus Conference.

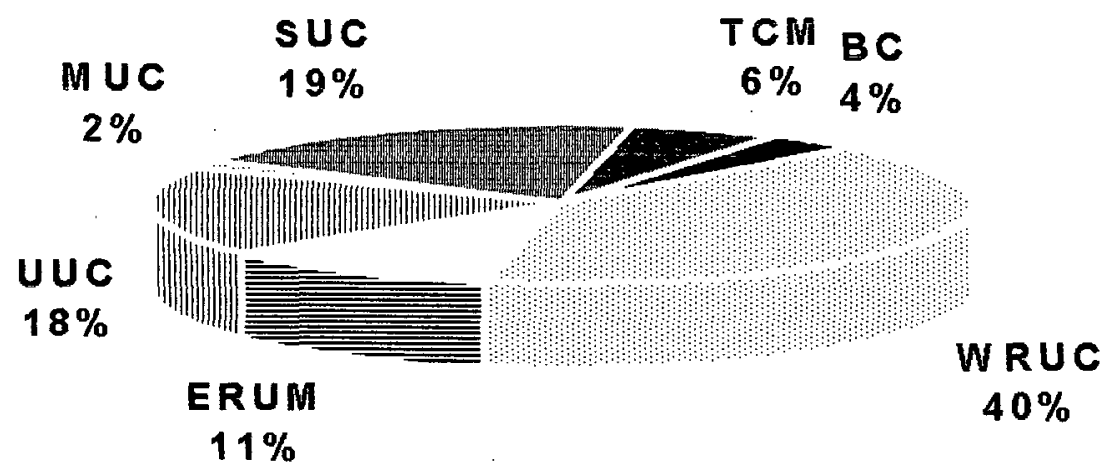

Fig. 15. The percentage of the population in the Unions and attached Fields of the Euro-Asia Division. 


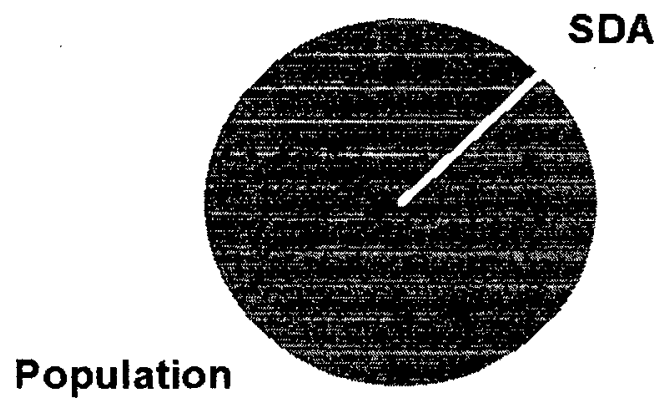

Fig. 16. Seventh-day Adventists' presence as compared to the population of the Euro-Asia Division. Source: Seventhday Adventist Yearbook (1996), 148.

According to table 9, the first three most populated areas are the West Russian Union, the Southern Union, and the Ukrainian Union Conferences.

Over half of the total population lives in the territory of the West Russian Union and the East Russian Mission. Thus, the goal of the church should be to establish an adequate presence in these most populated areas. The SDA church in the Ukraine has traditionally led in total membership in the Division. Even in 1987 , Adventists in the Ukraine constituted approximately 40 
percent of the total membership. ${ }^{1}$ Nevertheless, during 1991-1995, many new members were added to the other Union Conferences and attached Fields. Table 10 shows this growth throughout the period of public evangelism. Figure 17 presents the membership growth in the different parts of the Division.

According to table 10, the three largest Union Conferences in 1991 were the Ukrainian, Russian, and Moldova. By 1993, the picture had changed. The evangelistic crusades more than tripled the church membership in the Russian Union with the result that the Russian Union replaced the Ukrainian Union as the largest Union in the Division. This change is another reflection of the large number of evangelistic campaigns held in the Russian Union.

As was mentioned above, the largest campaigns during these two years were conducted in two Russian cities: Moscow and Nizhni Novgorod. The largest numbers of converts in 1992, which was the most successful year, were from these three Union Conferences and with the same order: RUC-15,264 , UUC $--7,958$, BUC- $-2,667.2$

${ }^{1}$ Rose Otis, "Interview with Elder Neal Wilson and Elder Mikhail Kulakov," Is There Faith in God in Russia? 1 $(1987): 5$.

2130 th Annual Statistical Report--1992, 12. 
Table 10

Comparative Membership Growth in the Different Parts of the Division during 1991-1995

\begin{tabular}{lrrrrr}
\hline $\begin{array}{l}\text { Parts of the } \\
\text { Division }\end{array}$ & 1991 & 1992 & 1993 & 1994 & 1995 \\
\hline RUC & 12,804 & 27,330 & 38,795 & -- & -- \\
\hline WRUC & -- & -- & -- & 30,603 & 32,350 \\
\hline ERUM & -- & -- & -- & 6,729 & 6,850 \\
\hline UUC & 20,092 & 26,883 & 36,603 & 43,626 & 51,154 \\
\hline MUC & 5,369 & 6,308 & 7,112 & 7,652 & 8,156 \\
\hline SUC & 4,003 & 4,570 & 5,168 & 5,093 & 5,486 \\
\hline TCM & -- & $-0-$ & $-1,188$ & -1 \\
\hline BUC & 4,355 & 6,782 & 8,207 & & 1,463 \\
\hline BC & 928 & 2,004 & 2,610 & 4,072 & 4,430 \\
\hline
\end{tabular}

Source: Data are based on the 129th Annual Statistical Report--1991, 12; the 130th Annual Statistical Report--1992, 12 ; the 131st Annual statistical Report--1993, 12; and the 132nd Annual Statistical Report--1994, 12. Data for 1995 are presented on the basis of information supplied by the Euro-Asia Division. Until 1994, membership of the BC is included in the numbers of the the BUC, although it is also presented separately. In 1994, several changes took place: the RUC was reorganized into the WRUC and the ERUM; the SUC was reorganized into the SUC and the TCM; the BC was left as a separate Conference after the transmission of the Estonian and Latvian Conferences into the Trans-European Division. RUC = the Russian Union Conference; WRUC = the West Russian Union Conference; ERUM = the East Russian Union Mission; UUC = the Ukrainian Union Conference; MUC = the Moldova Union Conference; SUC = the Southern Union Conference; TCM = the Trans-Caucasus Mission Field; BUC = the Baltic Union Conference; and $B C=$ the Belarus Conference. 


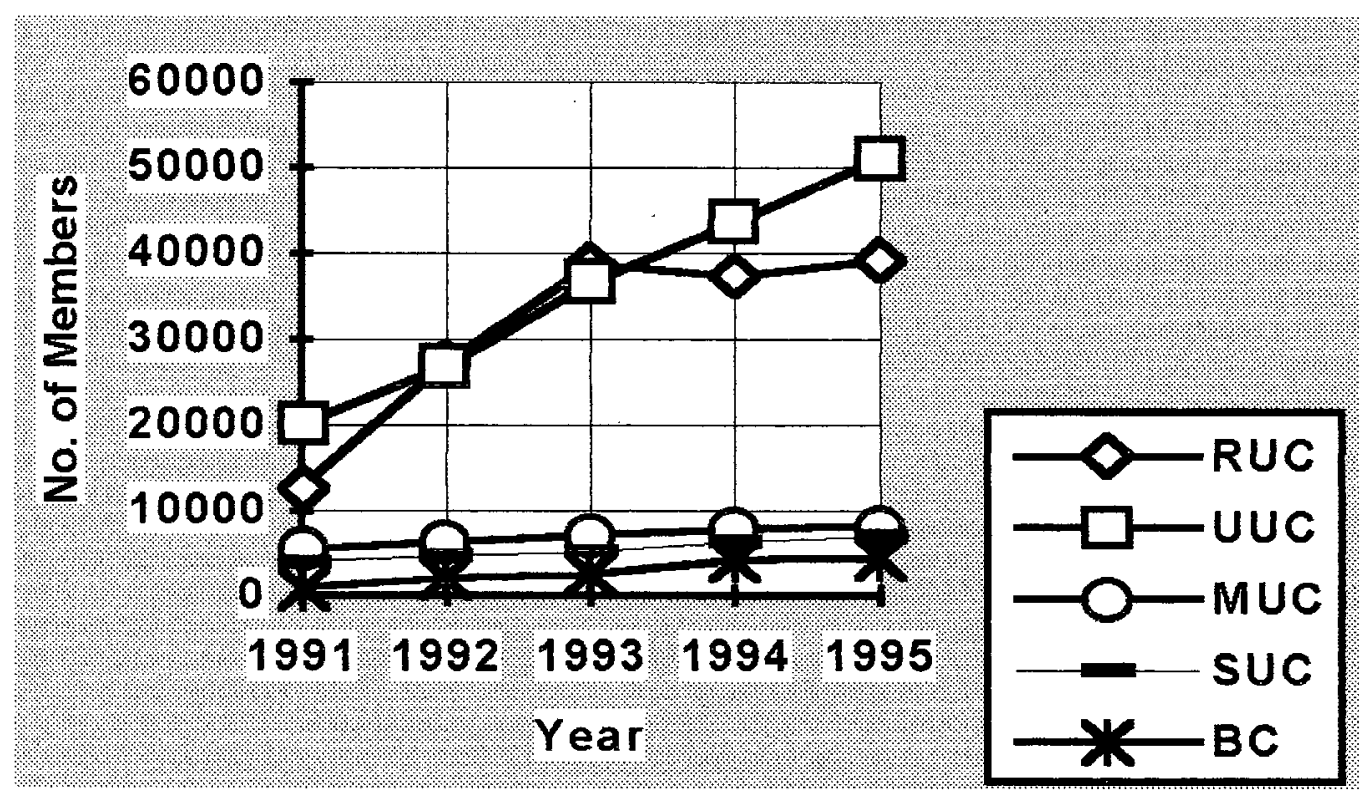

Fig. 17. Membership growth in the different parts of the Euro-Asia Division during 1991-1995. RUC = Russian Union Conference; UUC = the Ukrainian Union Conference; $M U C=$ the Moldova Union Conference; $\mathbf{S U C}=$ the Southern Union

Conference; $\mathrm{BC}=$ the Belarus Conference.

However, as figure 17 illustrates, in 1994 the picture changed again. The Ukraine continued to have large numbers of accessions while the Russian Unions showed a much slower growth rate. Although the large number of evangelistic campaigns contributed to the membership growth in the Ukraine, there is also another reason for its high growth rate. The Russian Union Conference had the largest number of accessions during 1991-1995, but it also was the Union which suffered most from apostasies. ${ }^{1}$ It seems that the Ukrainian Union did not drop from membership those who 
had apostatized to the degree that the Russian Unions did. Data from 1994, the year when the apostasy rate in the Division was the highest, show that the Ukrainian and Russian Unions began the year with almost the same membership: UUC--36,603; the former RUC--38,795.1 The numbers of accessions that year were also similar: UUC-9,678; the former RUC--8,137; but figures of apostasies were very different: UUC--1,856; the former RUC--8,236. ${ }^{2}$ Thus, what seems to be a weakness (high numbers of apostasies) could be strengh for the Russian Unions, while the apparent success of the Ukrainian Union could also be misleading because of not dealing with apostasies and nominality. As for Moldova, Adventists have always been well represented in this small territory. In 1985 there were 3,969 members (compared with 6,244 in Russia), although its population was only one thirty-fourth the population of Russia. ${ }^{3}$

Table 11 gives the AGR for the five parts of the Division in the 1991-1995 period. Figure 18 illustrates the data.

Table 11 and figure 18 show an interesing but unsteady picture. The former Russian Union Conference demonstrated rapid growth in 1992, but had a negative AGR in

\footnotetext{
${ }^{1} 132$ nd Annual Statistical Report--1994, 12 .

2 Ibid.

3123rd Annual Statistical Report 1985, 24; Seventhday Adventist Yearbook $(1986), 367,369$.
} 
1994. As was explained above, the RUC became a center for numerous evangelistic campaigns but then suffered from the highest rate of apostasy. It was obviously unprepared to care for the multitudes of new converts. Lack of church buildings and pastors, as well as an absence of a developed follow-up program, contributed to these tremendous losses. In addition, the vast territory made it very difficult to be in control and provide help at the right time.

Table 11

AGR for the Five Parts of the Euro-Asia Division during 1991-1995 (in Percentages)

\begin{tabular}{lccccc}
\hline $\begin{array}{l}\text { Parts of the } \\
\text { Division }\end{array}$ & 1991 & 1992 & 1993 & 1994 & 1995 \\
\hline RUC & 47.7 & 113.4 & 41.9 & -3.8 & 5.0 \\
\hline UUC & 21.9 & 33.8 & 36.2 & 19.2 & 17.2 \\
\hline MUC & 9.9 & 17.5 & 12.7 & 7.6 & 6.6 \\
\hline SUC & 9.0 & 14.2 & 13.1 & 21.5 & 10.6 \\
\hline BC & 17.9 & 115.9 & 30.2 & 56.0 & 8.8 \\
\hline
\end{tabular}

RUC = Russian Union Conference; UUC = the Ukrainian Union Conference; $M U C=$ the Moldova Union Conference; SUC = the Southern Union Conference; $B C=$ the Belarus Conference.

Although the Ukrainian Union Conference became the largest Union in 1994, as indicated in table 10, its highest AGR was in 1993. As was mentioned above, in this Division the Ukraine consolidated the largest percentage of 
Adventists prior to the period of public evangelism. Thus, the Ukrainian churches were more developed and more prepared to meet the challenges of rapid growth.

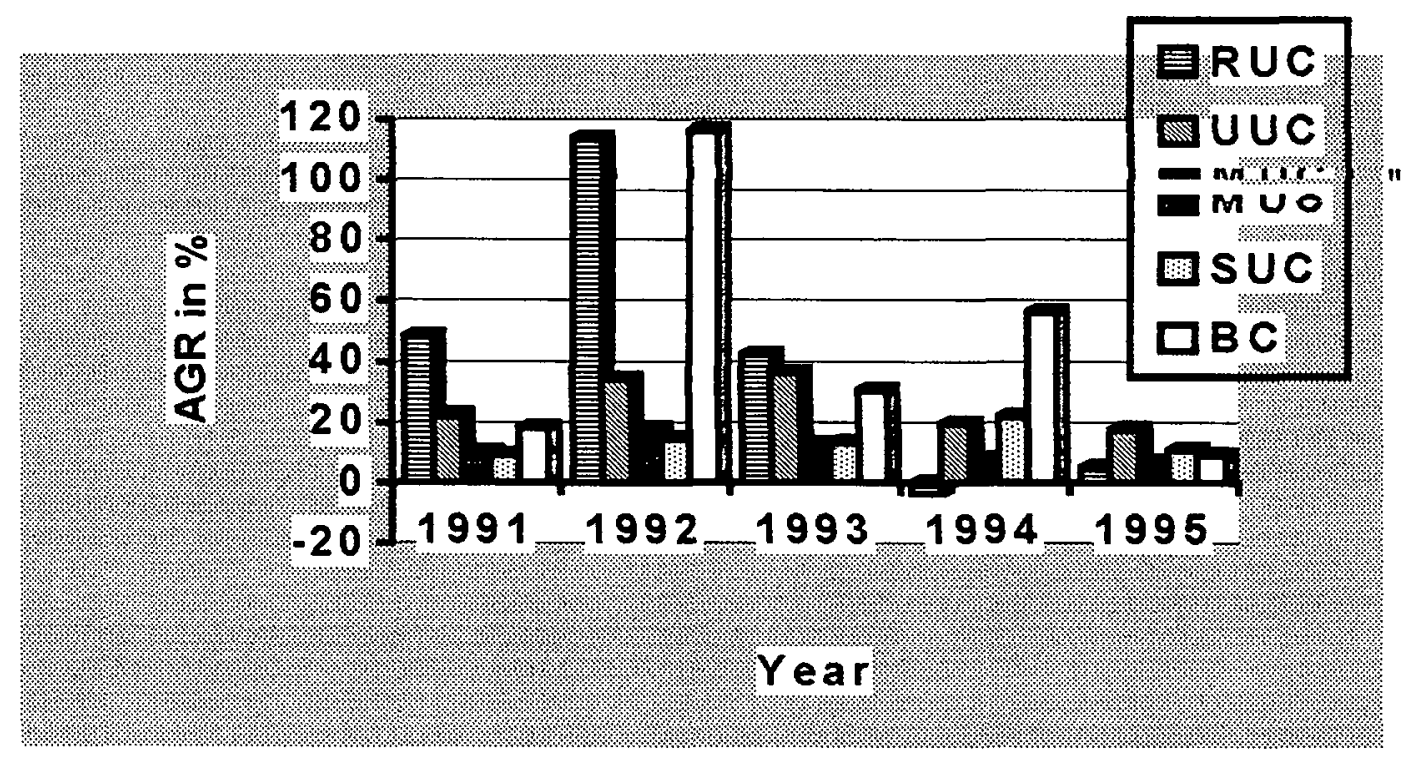

Fig. 18. AGR for five parts of the Division during the 1991-1995 period. RUC = Russian Union Conference; UUC = the Ukrainian Union Conference; MUC = the Moldova Union Conference; SUC = the Southern Union Conference; $\mathrm{BC}=$ the Belarus Conference.

In addition, growth in this Union was more gradual than that experienced in the RUC and it also was located in a much smaller territory which made it easier to keep everything under control. For example, in 1992, accessions in Russia $(15,264)$ outnumbered the total membership at the beginning of that year $(12,804)$, while in the Ukraine the total membership at the beginning of that year was 20,092 
and accessions for 1992 comprised 7,958. ${ }^{1}$ Although the UUC still suffered a pastoral shortage, it had the largest number of pastors in 1993 (299) as well as in 1994 (245) and in $1995(304) .^{2}$

The highest AGR for Moldova was in 1992, largely because of the evangelistic campaigns held that year. However, Moldova was also third in the Division for the total number of apostasies (1991-1994) as a percentage of total accessions with 15 percent. Furthermore, complex political and economic situations caused a transfer of some members to other places. In addition, the lack of sufficient pastors and church buildings also influenced the decline of the AGR.

The former Southern Union Conference showed good results. This former Conference had tremendous challenges: the second largest territory, diverse ethnic backgrounds among its population, large concentrations of Muslims, war going on in some of its areas, and the transition of thousands of German-Russians abroad. German-Russians have always been a responsive group of people to the Adventist message and also served as a leading force in many Adventist churches. Taking into consideration all of these challenges

${ }^{1} 130$ th Annual Statistical Report--1992, 12 .

2 "Otchet Secretarya EAO" ("Report of the Secretary of the Euro-Asia Division"), 10; "Otchet Secretarya" ("Report of the Secretary"), 5. 
and also the third largest percentage of apostasies in comparison to the total membership, it is a very good sign that in 1994 only the SUC and the BC had an AGR over 1.5 times more than in the previous year. In 1995, this Union Conference had the second largest AGR.

As table 11 and figure 18 show, very rapid growth took place in the Belarus Conference. This former part of the Baltic Union Conference had less than a thousand members in 1991, but in five years it surpassed the total membership of the former Baltic Union in 1991. The numbers show that its membership increased by 4.8 times during 1991-1995. Although additional research is needed to investigate reasons for this tremendous growth, there are several possible explanations. After the disintegration of the BUC, the Belarus Conference became a separate field. It attracted the attention of foreign evangelists and others who had compassion for the suffering of the Belarus people after the Chernobyl explosion. Thus, a number of evangelistic campaigns and charity enterprises were conducted there. In addition, the total population of this Conference $(10,322,980)$ is smaller than the population in the Russian capital city of Moscow. Belarus also occupies a relatively small territory with few serious cross-cultural challenges. Church leadership of the $B C$ and the members themselves are very active in evangelism, although they also 
experience great difficulties in view of their inadequate numbers of ministers and church buildings. Furthermore, it was easier to have a larger percentage of growth when the church membership was relatively small in the beginning and harder to grow the same rate as the membership increased (see AGR for 1992 and 1995 in table 11 and figure 18). Table 12 and figure 19 present data for the total accessions and apostasies in these parts of the Euro-Asia Division during 1991-1995.

Table 12

Total Accessions and Apostasies for the 1991-1995 Period and Apostasies as a Percentage of Total Accessions and Church Membership in 1995

\begin{tabular}{lccll}
\hline $\begin{array}{l}\text { Parts of } \\
\text { the } \\
\text { Division }\end{array}$ & Accessions & Apostasies & $\begin{array}{l}\text { Apostasies } \\
\text { as a } \\
\text { Percentage of } \\
\text { Accessions }\end{array}$ & $\begin{array}{l}\text { Apostasies } \\
\text { as a } \\
\text { Percentage } \\
\text { of Membrship }\end{array}$ \\
\hline RUC & 46,882 & 13,730 & 29.3 & 35.0 \\
\hline UUC & 44,382 & 5,333 & 12.0 & 10.4 \\
\hline MUC & 4,851 & 776 & 16.0 & 9.5 \\
\hline SUC & 8,544 & 815 & 9.5 & 11.7 \\
\hline BC & 5,109 & 1,361 & 26.6 & 30.7 \\
\hline
\end{tabular}

Source: Data are based on the 129th Annual Statistical Report--1991, 12; the 130th Annual Statistical Report--1992, 12 ; the 131st Annual statistical Report--1993, 12; and the 132nd Annual Statistical Report--1994, 12. Data for 1995 are presented on the basis of information supplied by the Euro-Asia Division. RUC = Russian Union Conference; UUC = the Ukrainian Union Conference; MUC = the Moldova Union Conference; SUC = the Southern Union Conference; $B C=$ the Belarus Conference. 


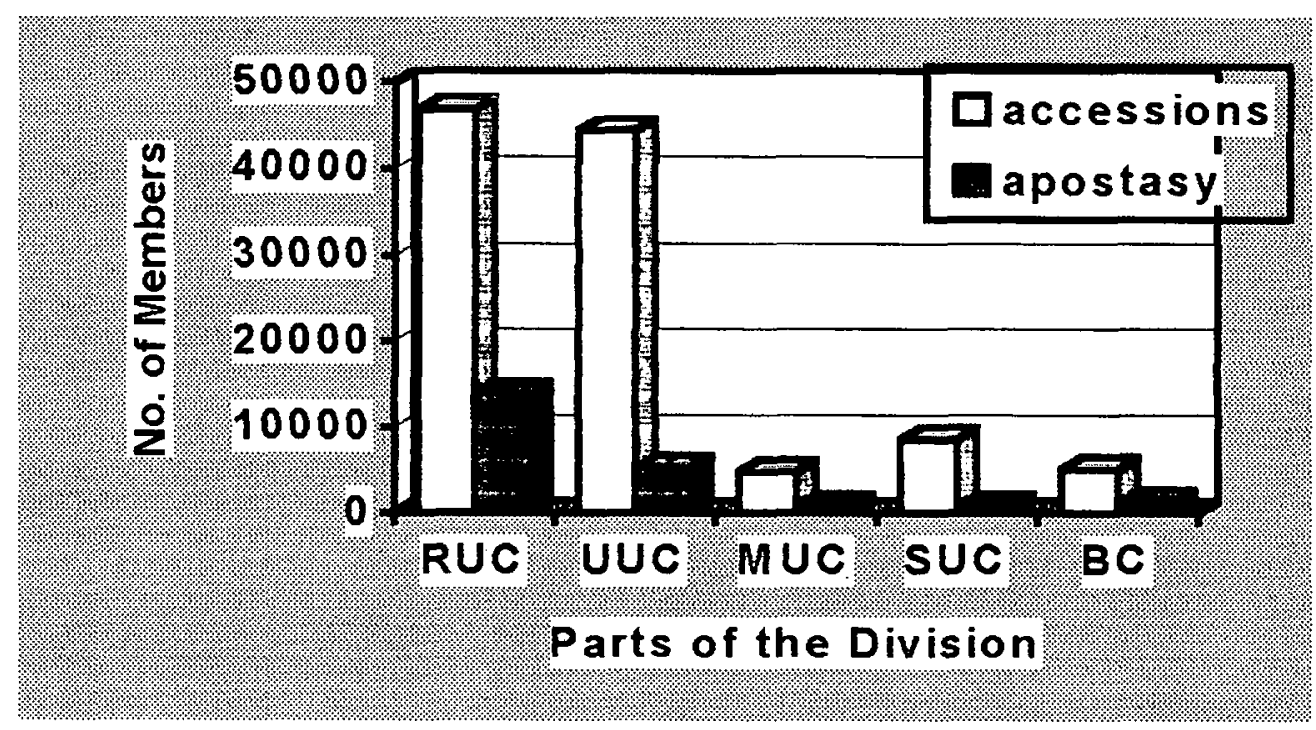

Fig. 19. Accessions and apostasies in five parts of the Division in the 1991-1995 period. RUC = Russian Union Conference; UUC = the Ukrainian Union Conference; $M U C=$ the Moldova Union Conference; $S U C=$ the Southern Union Conference; $\mathrm{BC}=$ the Belarus Conference.

It becomes obvious that the former Russian Union Conferences had the largest number of newly converted people and the greatest number of apostasies during 1991-1995. The Ukrainian Union Conference holds second place in both categories. It is interesting to note that the Ukraine had 2,780 apostasies during 1991-1994 and 2,553 apostasies in 1995. However, when you look at the number of apostasies as a percentage of accessions the Russian Unions have the highest percentage, followed by Belarus and then Moldova. Belarus had 376 apostasies during 1991-1994 and 985 apostasies in 1995 . 
When you rank apostasies as a percentage of church membership, the following order emerges: Russia, Belarus, and the former Southern Union Conference.

Table 13 gives the number of congregations and churches without church buildings. It also lists the number of pastors and the ratio of church members per minister in the Unions and attached Fields as of 1995.

Table 13

Number of Total Congregations and Those Without Church Buildings, and Number of Pastors and the Ratio of Members per Minister in 1995

\begin{tabular}{lcccc}
\hline $\begin{array}{l}\text { Part of the } \\
\text { Division }\end{array}$ & $\begin{array}{l}\text { Congregations } \\
\text { WRUC }\end{array}$ & $\begin{array}{l}\text { Church } \\
\text { Buildings }\end{array}$ & $\begin{array}{l}\text { Pastors } \\
\text { Ratio of } \\
\text { Members per } \\
\text { Minister }\end{array}$ \\
\hline ERUM & 72 & 174 & 248 & $1: 130$ \\
\hline UUC & 432 & 25 & 51 & $1: 134$ \\
\hline MUC & 90 & 223 & 304 & $1: 168$ \\
\hline SUC & 68 & 38 & 69 & $1: 118$ \\
\hline TCM & 11 & 3 & 68 & $1: 81$ \\
\hline BC & 38 & 2 & 16 & $1: 91$ \\
\hline
\end{tabular}

Source: Data are based on the information supplied by the Euro-Asia Division. WRUC = the West Russian Union Conference; ERUM = the East Russian Union Mission; UUC = the Ukrainian Union Conference; MUC = the Moldova Union Conference; SUC $=$ the Southern Union Conference; $\mathrm{TCM}=$ the Trans-Caucasus Mission Field; and $\mathrm{BC}=$ the Belarus Conference. 
Figure 20 shows the number of churches without church buildings in the different parts of the Euro-Asia Division in 1995. Figure 21 presents the number of congregations and pastors in 1995 .

Although figure 21 and the data in table 13 show that in the West Russian Union Conference, in the Southern Union Conference, and in the Trans-Caucasus Field there are no apparent needs for additional pastors, this does not reflect reality.

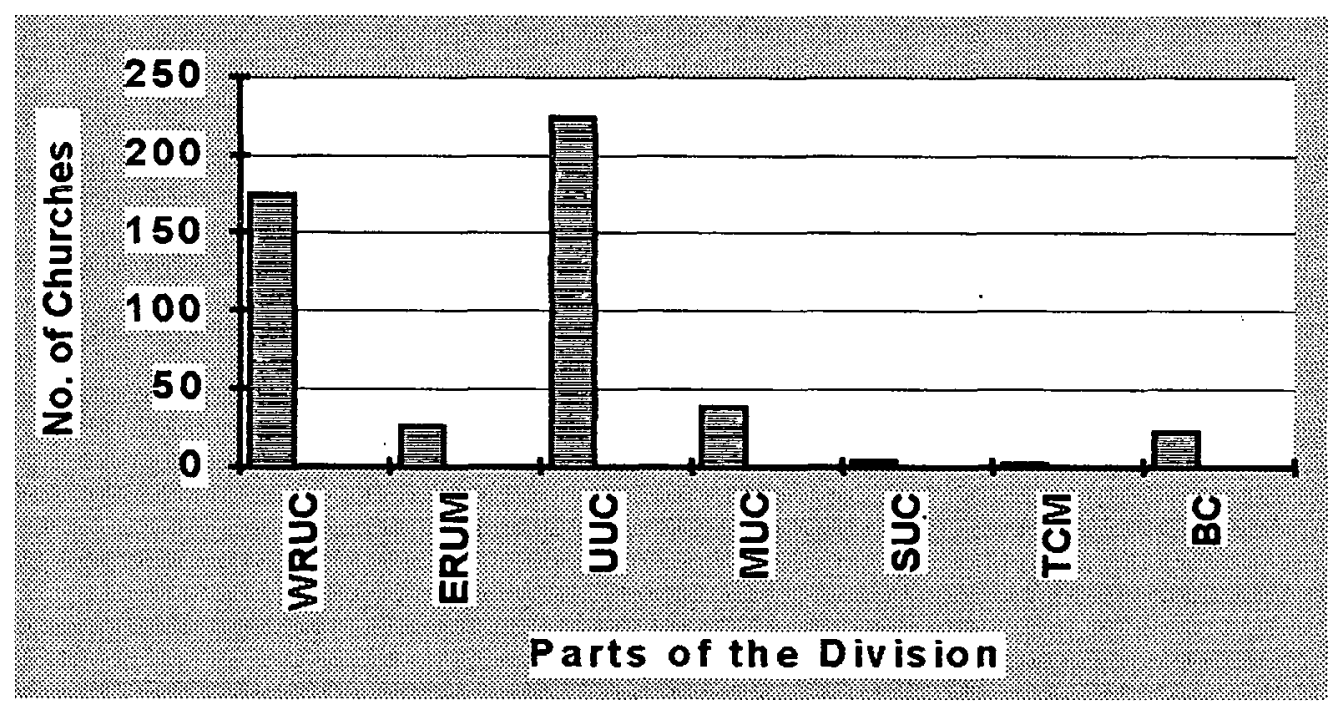

Fig. 20. Number of churches without church buildings in the different parts of the Division in 1995. WRUC = the west Russian Union Conference; ERUM = the East Russian Union Mission; UUC = the Ukrainian Union Conference; $M U C=$ the Moldova Union Conference; $\mathrm{SUC}=$ the Southern Union Conference; $\mathbf{T C M}=$ the Trans-Caucasus Mission Field; and $\mathrm{BC}=$ the Belarus Conference. 


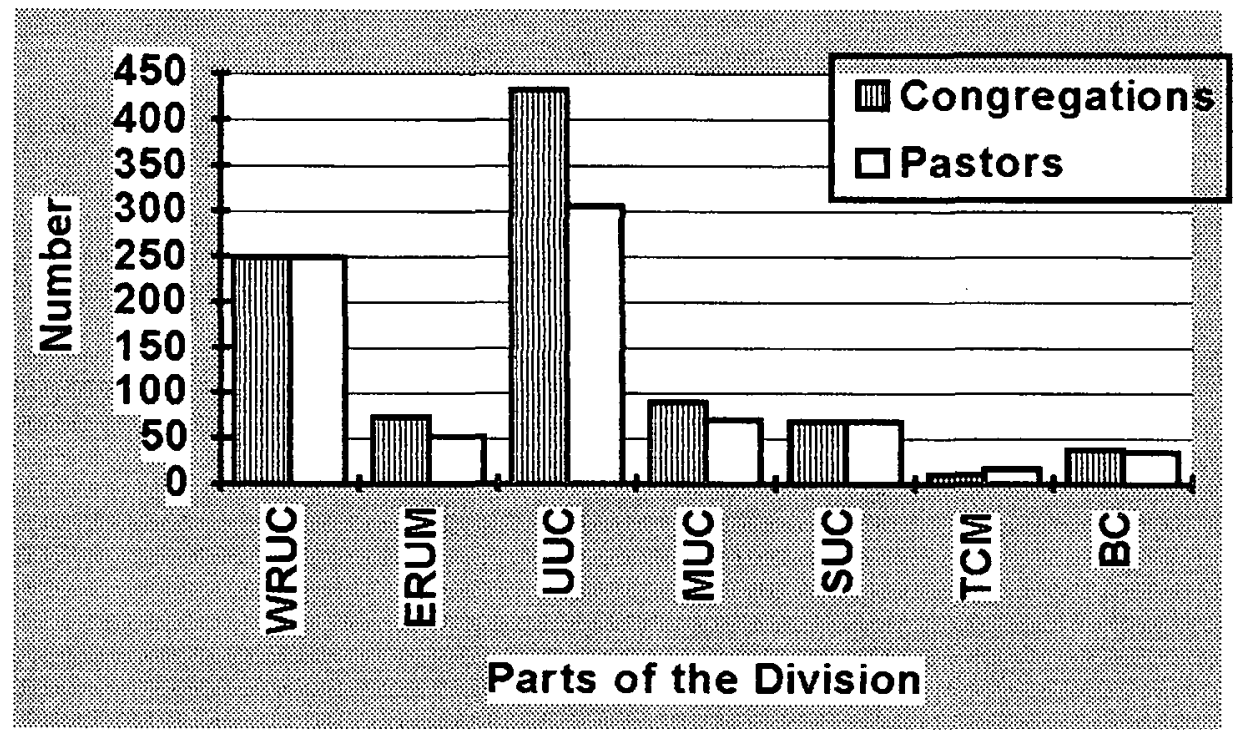

Fig. 21. Number of congregations and pastors in the different parts of the Division in 1995. WRUC = the West Russian Union Conference; $E R U M=$ the East Russian Union Mission; UUC = the Ukrainian Union Conference; MUC = the Moldova Union Conference; $\mathrm{SUC}=$ the Southern Union Conference; $\mathrm{TCM}=$ the Trans-Caucasus Mission Field; and $\mathrm{BC}=$ the Belarus Conference.

Since ministers in administrative positions are also included in the total number of pastors many congregations do not have a pastor. In addition, beginners in pastoral ministry, who do not have pastoral experience and who have had inadequate pastoral training are also included in the total number of pastors. Moreover, in each Conference there are three or five full-time administrators who are ordained or have pastoral licenses. Thus, for example, in the west Russian Union Conference there are seven local Conferences with over twenty administrators. In the Southern Union Conference about ten ordained ministers serve as 
administrators. ${ }^{1}$ Thus, in reality, in every Union

Conference or attached Field there are even fewer pastors actively involved in local church work and even more members per minister than table 13 shows. However, according to the data, the most desperate situation in 1995 was in the Ukraine, where the greatest number of church buildings and pastors was needed. Next in need was the West Russian Union which needed 174 church buildings. Both the East Russian Mission and Moldova were lacking more than 20 ministers each.

Table 14 gives the decadal growth rate for the five parts of the Euro-Asia Division.

Table 14

Decadal Growth Rate for the 1985-1995 Period (in Percentages)

\begin{tabular}{lc}
\hline Parts of the Division & DGR \\
\hline RUC & 527.8 \\
\hline UUC & 274.9 \\
\hline MUC & 105.5 \\
\hline SUC & 80.9 \\
\hline BC & 593.0 \\
\hline
\end{tabular}

RUC = Russian Union Conference; UUC = the Ukrainian Union Conference; $M U C=$ the Moldova Union Conference; $S U C=$ the Southern Union Conference; $\mathrm{BC}=$ the Belarus Conference.

\footnotetext{
${ }^{1}$ Seventh-day Adventist Yearbook (1996), 152, 155-157.
} 
Figure 22 illustrates the decadal growth rate in the Unions and attached Fields of the Division and shows clearly that the Belarus Conference was the fastest growing field during this decade. The former Russian Union Conference takes second place with last place occupied by the former Southern Conference. This again illustrate the challenge facing the church to stimulate growth in those areas where the territory is largely populated by Muslims.

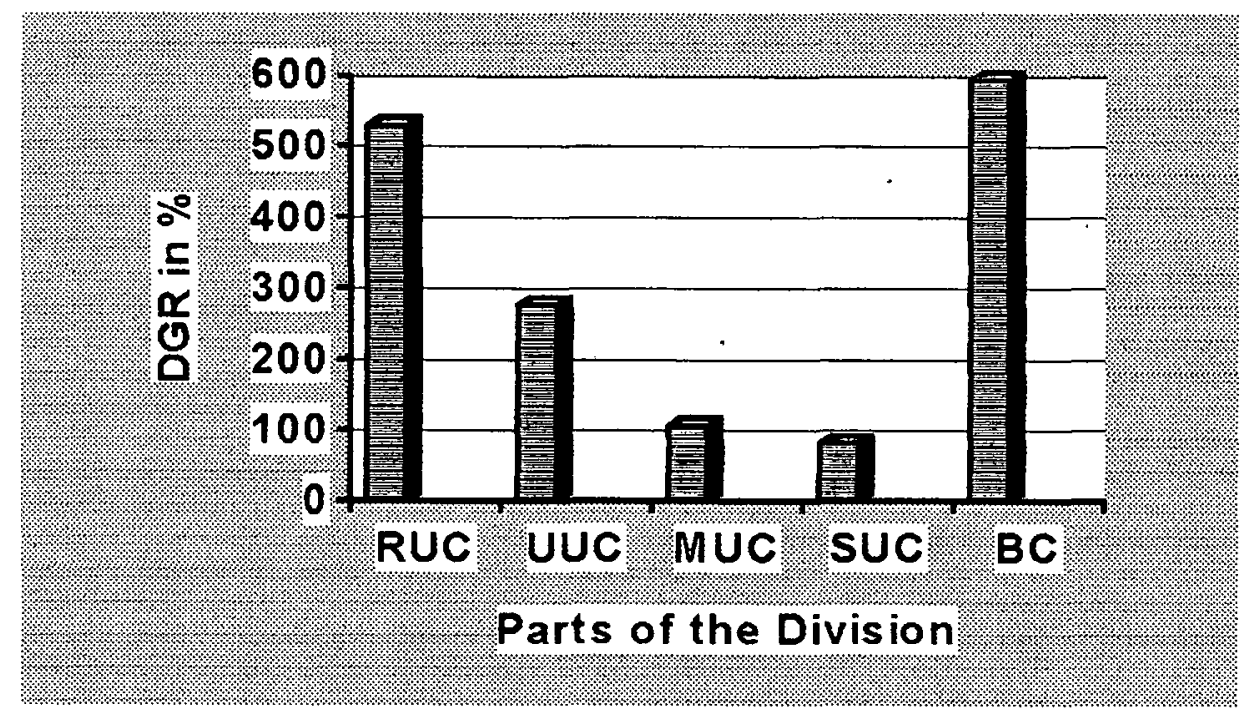

Fig. 22. Decadal growth rate of the Unions and attached Fields of the Division. RUC = Russian Union Conference; UUC = the Ukrainian Union Conference; MUC = the Moldova Union Conference; $\mathrm{SUC}=$ the Southern Union Conference; $\mathrm{BC}=$ the Belarus Conference.

This comparative analysis shows that the church has grown tremendously, although not equally, in all parts of the Division. It is also a fact that the Division is 
presently facing the tremendous challenge of reaching multitudes of unreached people throughout the Division territory. Although public evangelism has made a great contribution, nevertheless, it seems that there is a need for an organized strategy for mission outreach that would involve every member.

Table 15 reveals the situation of the Adventist presence in the territory of the Unions and attached Fields as of the summer of 1995 .

Table 15

The Percentage of Adventists as Compared to the Population of the Unions/Missions and the Ratio of Non-Adventists per SDA Member in 1995

\begin{tabular}{lcc}
\hline $\begin{array}{l}\text { Parts of the } \\
\text { Division }\end{array}$ & Percentage & Ratio \\
\hline WRUC & 0.03 & $1: 3,630$ \\
\hline ERUM & 0.02 & $1: 4,850$ \\
\hline UUC & 0.09 & $1: 1,138$ \\
\hline MUC & 0.19 & $1: 531$ \\
\hline SUC & 0.01 & $1: 10,394$ \\
\hline TCM & 0.007 & $1: 13,825$ \\
\hline BC & 0.04 & $1: 2,467$ \\
\hline
\end{tabular}

WRUC = the West Russian Union Conference; ERUM = the East Russian Union Mission; UUC = the Ukrainian Union Conference; MUC = the Moldova Union Conference; SUC = the Southern Union Conference; $\mathrm{TCM}=$ the Trans-Caucasus Mission Field; and $\mathrm{BC}=$ the Belarus Conference. 
Figure 23 presents the percentage of Adventists as compared to the population of the Unions and attached Fields of the Euro-Asia Division.

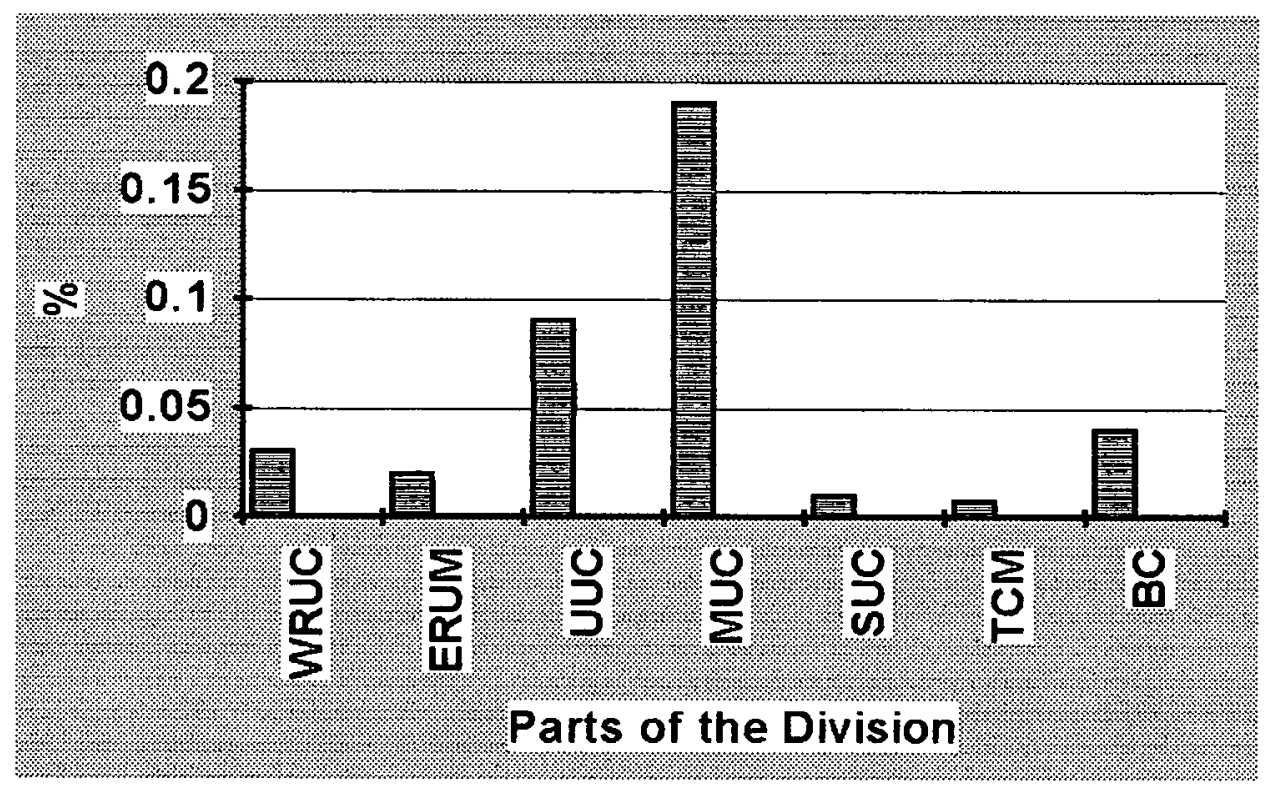

Fig. 23. Percentage of Adventists as compared to the population of the Unions and attached Fields of the Division. WRUC = the West Russian Union Conference; ERUM = the East Russian Union Mission; UUC = the Ukrainian Union Conference; MUC = the Moldova Union Conference; SUC = the Southern Union Conference; $\mathrm{TCM}=$ the Trans-Caucasus Mission Field; and $\mathrm{BC}$ $=$ the Belarus Conference.

The highest percentage of SDA members is in Moldova (about $0.2 \%$ ) and in the Ukraine (about $0.1 \%$ ). The smallest number of Adventists is in the Trans-Caucasus Field and in the Southern Union.

It is interesting to note that in spite of increased membership, the ratio of non-Adventists per SDA member in 
the Southern Union was smaller in $1994(1: 10,299)^{1}$ than in 1995. This can be explained by the very rapid growth of population in that area. Thus, the Southern Union Conference and the Trans-Caucasus Field must become areas of special mission focus for the Division.

In spite of the rapid growth in recent years, no Union Conference or Field of the Division comprises even 1 percent of the total population in its territory. Much more should be done to reach the former soviet people.

Thus, the analysis shows that all Unions and attached Fields are experiencing the same challenges as the whole Division.

\section{Summary}

In summary, the Adventist church in the territory of the Euro-Asia Division has a rich history of hardships, persecution, suffering, and God's Providence. The Adventist message came to tzarist Russia from Adventist tracts sent by German immigrants in America to their relatives and friends in Russia. There were also some people in Russia who began to keep the Sabbath because they had discovered it by themselves through personal Bible study. The first volunteer missionary came to Crimea, the southern part of Russia, from South Dakota in 1883. He was an aged man of German-Russian background, about eighty years old. In 1886,

\footnotetext{
${ }^{1}$ Seventh-day Adventist Yearbook (1995), 103.
} 
the first Adventist congregation was formed, and by the end of the year there were thirty Adventist members in Russia. Ever since then, the Adventist church in this part of the world has experienced changing waves of repression and relative religious freedom.

In 1916, one year before the October Revolution, church membership reached 6,720. Ten years later the number grew to 12,282 with representatives from twenty nationalities. During the Soviet regime, there were several periods of persecution. The most severe one was under the leadership of Stalin, when the Adventist church lost almost all of its pastors and several thousands of its members. Nevertheless, during the times of peace the church gathered its scattered flock, built church buildings, and won new members. In 1971, contact with the worldwide Adventist church was reestablished. Regular visits by GC leaders became possible because of changing attitudes toward religion in the Soviet government. In 1985 there were 31,305 Adventists in the territory of the former soviet Union.

The decade of 1985-1995 was a long-awaited answer to the prayers of many believers from this part of the world. It brought new opportunities for the church and tremendous membership growth. The first half of the decade (1985-1990) can be called a period of transition. During that time, 
both the Soviet state and the church went through tremendous changes. New policies of glastnost and perestroika slowly began to move the country towards a religious freedom. The collapse of the communist ideology created a spiritual vacuum in the hearts of the former Soviet people. The Adventist church took this advantage of opportunities for evangelism and the establishment of a solid church structure. In 1987-1988, the Adventist seminary was built, which became the first Protestant seminary in this country. In 1990, the Division with five Union Conferences was formed. During this period (1985-1990), the church membership grew from 31,305 to 37,388 .

The second period of the decade (1991-1995) can be called a period of public evangelism. Hundreds of evangelistic crusades were conducted by foreign and local ministers all over its vast territory. The largest crusades were conducted in Moscow by Mark Finley, and in Nizhni Novgorod and in Kiev by John Carter.

However, rapid growth in membership also brought challenges the Division was not prepared for. The lack of church buildings forced the church to rent public halls, which could not provide stability, could not provide the needed church enviroment, or worship atmosphere, and could not provide facilities for the different Sabbath school departments. The lack of pastors caused a deficiency in 


\section{1}

pastoral care and much-needed church support for the newly converted members. A high rate of apostasy was the result.

A comparative analysis of the Union Conferences and attached Fields of the Division shows that the former Russian Union Conference had the greatest number of accessions during this period and the highest rate of apostasies. The Ukraine has grown to become the largest Union but it is presently facing the challenge of assimilating the many new believers since it also has the greatest need for pastors and church buildings. Belarus has the highest DGR for this decade and the second highest number of apostasies as a percentage of total membership and accessions. Much needs to be done in Belarus to keep the new members. The Trans-Caucasus Mission and the Southern Union Conference have the smallest percentage of Adventists in their territories, but the greatest diversity in the ethnic and religious backgrounds of its population. Moldova is the Union Conference with the smallest ratio of nonAdventists per SDA member. However, it is experiencing the same challenges as the other parts of the Division: lack of church buildings, lack of pastors, high apostasy rates among new converts, and still millions of unreached people.

In spite of fantastic growth and numerous evangelistic campaigns there are still vast territories in the Division that remain without an Adventist presence. As 
the church recognized that additional methods must be used along with public evangelism, lay members were called to be actively involved in personal evangelism. Although the increased lay involvement have produced good results, a thoroughly planned strategy for mission outreach is still needed. This is especially so in the areas where the indigenous peoples belong to non-Christian religions and where cross-cultural evangelism is required. The words of the former president of the Euro-Asia Division illustrate achievements and still-remaining challenges:

Hundreds of new towns, cities, and regions have been entered with the Advent message through public evangelism, media evangelism, literature evangelism, youth evangelism and now a very heavy emphasis on lay evangelism. Some of our major challenges include greatly rising costs, secularism and materialism, vast distances, lack of church buildings, and the need for more workers. In addition, we face the enigma of how to reach the large Muslim and smaller Buddhist populations of our territory.

Thus, the analysis of this decade (1985-1995) shows that the Euro-Asia Division is presently facing the following challenges: high apostasy rates among new converts, lack of enough pastors and church buildings and multitudes of unreached people. These challenges are common for the whole Division and for each of its Unions and attached Fields. The Adventist church in this Division needs a special strategy that can meet these needs. Chapter

\footnotetext{
$1_{\text {Ted N. C. Wilson, "Presidents' World Report," }}$ Adventist Review, special issue, June 1995, 18.
} 
2 suggests a home-church approach as a possible solution for these great challenges. 
CHAPTER 2

HOME CHURCHES: A POSSIBLE SOLUTION

This chapter suggests a house-church approach as a possible solution to the main challenges the Euro-Asia Division is presently facing. As was shown in the first chapter, these challenges are the apostasy of new converts, the inadequate number of pastors and church buildings, and the millions of unreached people.

\section{Challenge of the Apostasy of New Members}

This section presents (1) reasons for apostasy among new members in the Euro-Asia Division as seen by the church, (2) needs of newly converted members, and (3) a house-church approach as a possible solution to these needs.

The Reasons for Apostasy as Seen by the Church in the Euro-Asia Division

In the fall of 1995, 121 church members from different parts of the Euro-Asia Division were given a questionnaire. $^{1}$ The group included administrators (18\%), who came as delegates to the Annual Meeting held in Moscow, and also pastors and elders (30\%), deacons (14\%), Sabbath

\footnotetext{
${ }^{1}$ See p. 4 , above, and appendix 2 .
} 


\section{5}

School teachers (13\%), Bible workers (5\%), and youth leaders, colporteurs, and other active and non-active lay people, who came to the Zaokski Seminary for an intensive pastoral training. Many in the group (66\%) were members who had been converted since 1990.

Question 1 in the first section of the questionnaire stated: "What are the main reasons why new members apostatize?" Respondents were given a choice of six possible reasons, which they were to rate on a scale of 1 to 5, with 1 being "very important" and 5 being "not so important." Table 16 presents the response rates to only those reasons that were rated as "very important" and "important."

These reasons can be divided into three groups: very significant reasons (total of both $66 \%-100 \%$ ); significant reasons (total of both $33 \%-66 \%$ ); and not very significant reasons (total of both less than 33\%). The results show that "no deep personal relationships with Christ" and "loneliness in the church" were considered as very significant reasons. Reasons such as "stopped growing spiritually," "not enough information before baptism" and "disappointment" were viewed as significant. Doctrinal disagreements were not perceived as the major reason why new converts leave the church. 
Table 16

Reasons Why New Members Apostatize $(\underline{\mathrm{N}}=121)$

\begin{tabular}{llll}
\hline Reason & $\begin{array}{l}\text { Very } \\
\text { Important }\end{array}$ & Important & $\begin{array}{l}\text { Total of } \\
\text { Both }\end{array}$ \\
\hline $\begin{array}{l}\text { No deep personal } \\
\text { relationship with } \\
\text { Jesus Christ }\end{array}$ & $69(57 \%)$ & $22(18 \%)$ & $91(75 \%)$ \\
\hline $\begin{array}{l}\text { Loneliness in the } \\
\text { church }\end{array}$ & $49(40 \%)$ & $35(29 \%)$ & $84(70 \%)$ \\
\hline $\begin{array}{l}\text { Stopped growing } \\
\text { spiritualiy }\end{array}$ & $29(24 \%)$ & $25(21 \%)$ & $54(45 \%)$ \\
\hline $\begin{array}{l}\text { Not enough } \\
\text { information before } \\
\text { baptism }\end{array}$ & $28(23 \%)$ & $18(15 \%)$ & $46(38 \%)$ \\
\hline $\begin{array}{l}\text { Disappointment-- } \\
\text { Christianity does } \\
\text { not work in my life }\end{array}$ & $13(11 \%)$ & $27(22 \%)$ & $40(33 \%)$ \\
\hline $\begin{array}{l}\text { Doctrinal } \\
\text { disagreements }\end{array}$ & $8(7 \%)$ & $18(15 \%)$ & $26(21 \%)$ \\
\hline
\end{tabular}

In response to question 2 "Why do members become missing?" respondents rated seven suggested reasons as shown in table 17. These reasons can also be divided into three groups: very significant reasons (total of both $66 \%-100 \%$ ), significant reasons (total of both $33 \%-66 \%$ ), and not very significant reasons (total of both less than 33\%). The "lack of personal contacts with new converts" and the "lack of knowledge concerning the new converts' personal problems" are viewed as very significant reasons. Such reasons as "infrequent home visitations," the "natural results from mass conversions," and "lack of training among pastors" are 
considered as significant. "Inadequate number of pastors" and "difficulty in finding out when a person stopped attending church" are viewed as not very significant reasons.

Although the questionnaire was not filled out by those who apostatized, I feel that the results are still valid. First of all, most of the participants were personally involved in working with those who apostatized. Second, a large proportion of the group was comprised of newly converted Adventists who had themselves experienced similar problems.

Table 17

Reasons Why Members Become Missing $(\underline{N}=121)$

\begin{tabular}{|c|c|c|c|}
\hline Reason & $\begin{array}{l}\text { Very } \\
\text { Important }\end{array}$ & Important & $\begin{array}{l}\text { Total of } \\
\text { Both }\end{array}$ \\
\hline $\begin{array}{l}\text { Lack of personal contacts } \\
\text { with new converts }\end{array}$ & $70(58 \%)$ & $25(21 \%)$ & 95 ( 79 응) \\
\hline $\begin{array}{l}\text { Lack of knowledge } \\
\text { concerning the new } \\
\text { converts' personal problems }\end{array}$ & $58(48 \%)$ & $25(21 \%)$ & $83(69 \%)$ \\
\hline Infrequent home visitations & $38(31 \%)$ & $32(26 \%)$ & $70(58 \%)$ \\
\hline $\begin{array}{l}\text { Natural results from mass } \\
\text { conversions }\end{array}$ & $52(43 ㅇ ㅡ ㅇ)$ & $15(12 \%)$ & $67\left(55 \frac{\circ}{6}\right)$ \\
\hline $\begin{array}{l}\text { Lack of training among } \\
\text { pastors }\end{array}$ & $33(27 \%)$ & $18(15 \%)$ & $51(42 \%)$ \\
\hline $\begin{array}{l}\text { Inadequate number of } \\
\text { pastors }\end{array}$ & $14(12 \%)$ & $15(12 \%)$ & $29(24 \%)$ \\
\hline $\begin{array}{l}\text { Difficulty in finding out } \\
\text { when a person stopped } \\
\text { attending church }\end{array}$ & $16(13 \%)$ & $12(10 \%)$ & $28(23 ㅇ ㅡ ㅇ)$ \\
\hline
\end{tabular}


Thus, the questionnaire shows that the problem is relational rather than conceptual. Those who apostatized had failed to form meaningful vertical (with God) and horizontal (with other church members) relationships. The church had also failed to provide an environment where such relationships could be developed, nurtured, and strengthened. Why were relationships so important for those people? Was not the fact that they had found the truth more significant? How could the church have met their needs? The following section sheds more light on these questions.

\section{Home Churches as a Possible Solution to the Needs of New Converts}

Newly converted members have come to the church from a challenging and rapidly changing world. Urbanization, industrialization, and migration have placed people in new and changing circumstances. In addition, scientific achievements and education have significantly changed people's lifestyles and their worldview, which have become increasingly secular. ${ }^{1}$

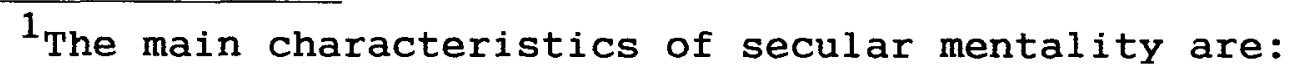
contingency or naturalism, which explains everything from the perspective of cause-effect; autonomy, which views that an autonomous person is able to make decisions by himself, and does not need God's guidance; relativity, which does not accept a concept of absolute truth, instead suggesting that it depends on a situation; temporality, which views one person's life as limited in time, and thus forces the philosophy of taking from 1 ife as much as possible. See Jon Paulien, Present Truth in the Real World (Boise, ID: Pacific Press, 1993), 43-46. All these characteristics obviously drive God out of a human life. Nevertheless, it does not 
The collapse of the communist regime created a spiritual vacuum. In the past few years many of those who earlier had rejected God or believed in a secular way discovered that they were robbed of spiritual things and were not given anything in return. 1 They turned to the church, ready to exchange their secular worldview for faith and religion. They looked to the church to meet their religious and relational ${ }^{2}$ needs. These needs can be divided into two blocks: needs in relation to God and needs in relation to people.

Questions may arise: How can these needs of new members be met in house churches? Are house churches more effective in this regard than large congregations? To answer these questions, the major needs of secular people and advantages of a home-church approach in relation to them are presented below.

necessarily mean that a secular person is a convicted atheist. As Paulien states, "a secular person is certainly not an atheist, someone who has consciously rejected religion in the ultimate sense. He or she may believe in God, yet not be continually conscious of God's involvement in the practical matters of everyday life." Ibid., 47.

${ }^{1}$ George Otis, Jr., The Last of the Giants (Grand Rapids, MI: Chosen Books, 1991), 37.

${ }^{2}$ See pp. 104-108, above. 
Home Churches and the Needs

in Relation to God

1. Need for a cosmic philosophy. One of the needs of secular people is for a cosmic philosophy which shows "that they belong to a meaningful and ordered universe." 1 God put this hunger in people so they will search out the reasons for their existence. As Mark Finley shows, they have three basic questions: "Where did I come from? Why am I here? Where am I going?" 2

Thomas Wolf calls a modern man, particularly in an urban setting, a longing person, because "the gods of the past seem so inadequate here, yet the forces of the supernatural, especially the evil supernatural, are so evident." 3 This seems very true of the situation in the Euro-Asia Division, where people are very conscious of supernatural forces. For example, it was reported after evangelistic meetings in Magadan that "many times people would expect us to interpret their dreams." 4

Since secular people very much appreciate the law of cause-effect, the more logically all doctrines are fitted

\section{${ }^{1}$ Paulien, 131 .}

${ }^{2}$ Mark Finley, "Reaching Secular People," Ministry, October 1993, 17.

3 Thomas A. Wolf, "Oikos Evangelism: Key to the Future" in Future Church, ed. Ralph W. Neighbour, Jr. (Nashville, TN: Broadman Press, 1980), 160-161.

${ }^{4}$ Chamberlin, 20. 
together in a big picture, the more convincing it sounds to them. The SDA church has a legacy of the great controversy scheme, which is, as Pauline says, "a great organizing principle for our personal concept of the universe and our place in it." 1

This need for a cosmic philosophy can be partially satisfied in the big congregations, where from time to time the great controversy theme is brought to the attention of listeners. However, new converts need more. As George Hunter III says, many of them are "biblically illiterate, "2 and thus need more specific instruction. Additionally, new believers want to see practical applications of this new cosmic philosophy to their own lives. Coming to the Adventist church, they expect to find answers to their prayers, to experience the protection of angels, and to receive explanations for supernatural phenomena. This can be more successfully done under the support and direction of a small group of people. It is there, amid such a group, that personal experiences and problems can be shared, prayer requests uplifted, and answers to puzzling situations found. And thus, small groups can help this new cosmic philosophy become a living principle for the newly converted instead of becoming just a theoretical doctrine.

${ }^{1}$ Paulien, 131 .

${ }^{2}$ George G. Hunter III, How to Reach Secular People (Nashville, TN: Abingdon Press, 1992), 44. 
2. Need for commitment and belonging to someone or something meaningful. Secular people have another need, "a need for commitment to an issue or a person that is clearly greater than themselves." 1 It also can be called a need for meaning, 2 which "must come from outside the ordinary." 3 Thus, after new believers have found a new cosmic philosophy with Jesus, who is much greater than anyone else, they want to commit themselves to Him and His church.

Interestingly enough, there is an interconnectedness between commitment, deeds, and meaning. True commitment is usually expressed in active deeds. As long as a person is willingly doing something for which he has committed himself, it becomes meaningful for him. And the more meaningful it is, the more a person wants to do something for it. The less he or she is doing, the less meaningful it may become. Commitment is closely connected with belonging, since people do not tend to belong to something that has lost its meaning for them. As Byron Deshler puts it:

The need to belong can be satisfied only when that to which we belong holds deep meaning for us by shaping our

${ }^{1}$ Paulien, 128 .

${ }^{2}$ Gottfried Oosterwal, "The Process of Secularization" in Meeting the Secular Mind: Some Adventist Perspectives, ed. Humberto M. Rasi and Fritz Guy (Berrien Springs, MI: Andrews University Press, 1985), 59.

$$
3 \text { Paulien, } 129 .
$$


lives into the pattern of Christ. But this takes place only as we are drawn into active participation.

Thus, if baptism was the first and the last activity new converts had to do to express their commitment, the commitment would soon die out. Lyle E. Schaller states that there is a tendency for new converts to become inactive if they "do not become part of a group, accept a leadership role, or become involved in a task during their first year." ${ }^{2}$ Ervin R. Stutzman supports this, arguing that new believers soon begin to reevaluate their decision to join the church. They begin to ask the following questions: "Are my new friends as good as my old ones?" "Does the group meet my needs?" "Is my contribution valued?" 3 The answers are of crucial importance since, if they are satisfactory, the new converts "will probably stay. If not, they will leave or gradually become inactive." Stutzman shows that "seventy percent of those who become inactive do so in the first 12 months." 4

${ }^{1}$ G. Byron Deshler, The Power of the Personal Group (Nashville, TN: Tidings, n.d.), 15.

${ }^{2}$ Lyle E. Schaller, Assimilating New Members (Nashville, TN: Abingdon Press, 1978), 77.

${ }^{3}$ Ervin R. Stutzman, Welcome! A Biblical and Practical Guide to Receiving New Members (Scottdale, PA: Herald Press, 1990), 70.

${ }^{4}$ Ibid. 
Thus, a need for commitment and belonging to someone or something extraordinary can be met when opportunities for active involvement are secured. In the big congregations, often it is impossible to develop enough options for every member to be meaningfully involved either in the activities of the church service or in the besides-the-church-service work. Mission-oriented small groups can solve this problem. Opportunities to serve one another with spiritual gifts are provided by the "everyone-involved type of gathering." 1 In addition, home churches are a perfect place for new members to be actively involved in saving others. They will feel themselves needed, their contribution valued, their commitment strengthened. The words "in saving others, we save ourselves" will come true. In the large congregations, the opposite is more likely to happen: new members become non-involved in the church work and mission and, thus, become inactive, indifferent, lukewarm, and may even be lost.

3. Need to be free from guilt. Another need of new members is to be released from guilt. 2 secular people "often have a very strong sense of obligation, of where they

$1_{\text {Nate Krupp, God's Simple Plan for His Church--and }}$ Your Place in It: A Manual for House Churches (Woodburn, OR: Solid Rock Books, 1993), 58.

2 Paulien, 129 . 
want to be in life." And "the failure to achieve this leaves a sense of brokenness that cries out to be fixed." 1 Many have high expectations once they become members of the church. However, they soon discover that there are still mistakes in their lives. This produces pain and multitudes of guilty people who need forgiveness, transformation, and guidance that can be provided only by Jesus Christ. Thus, there is a need for values, Messiah, salvation, and personal dignity ${ }^{2}$ alongside the need to be freed from guilt.

These needs cannot be met once and forever. It is a lifetime journey. Personal relationships with Jesus must be formed and sustained. However, the personal knowledge of Christ cannot be achieved merely by listening to the Sabbath sermons. In large group meetings people tend to be spectators, but observers are rarely changed. ${ }^{3}$ This is why large group meetings "should never be the only meetings that church members experience." 4

Clarence Schilt argues that "the image of God does not develop at all effectively in individual isolation or in

1 Ibid., 129-130.

2 Oosterwal, 59 .

3 Philip A. Anderson, Church Meetings That Matter (Philadelphia: United Church Press, 1965), 9.

${ }^{4}$ Ibid. 
large corporate settings." 1 Small groups remain an ideal place for the knowing of Christ through Bible study, because there people have ownership in this study process. ${ }^{2}$ This need for Messiah suggests having practical knowledge of a Person, not merely information about Him. Thus, home churches can help people to know Jesus personally and grow into mature stature as forgiven and successful Christians much more than the traditional corporate services can.

4. Need for guidance in lifestyle. Secular people also have a need for guidance in their lifestyle. ${ }^{3}$ Oosterwal points out that they have a need for an abundant life (health, prosperity, peace, justice, social acceptance, freedom, etc.). ${ }^{4}$ Hunter says that they "are seeking life before death." 5

Conversion brings a lot of changes in the new members' lifestyle. Many of them have a hard time changing their behavior and applying new principles in their everyday lives. Paulien states that secular people tend to oppose

${ }^{1}$ W. Clarence Schilt, Dynamic Small Groups (Hagerstown, MD: Review and Herald Publishing Association, $1992), 31$.

2 Jeffrey Arnold, The Big Book on Small Groups (Downers Grove, IL: InterVarsity Press, 1992), 121.

3 Paulien, 134 .

${ }^{4}$ Oosterwal, 59 .

${ }^{5}$ Hunter, 45 . 
the standards forced on them from outside. Rather, they prefer to choose by themselves what way they should follow. ${ }^{1}$ Research proves that group discussion is a more successful method of teaching than the lecture, if the goal is to change behavior. ${ }^{2}$ In addition, decisions to change behavior patterns are longer lasting and more effective if they are made in a group setting than decisions made individually. 3 It is interesting to note that Ellen G. White suggests, in the context of camp meetings, that sometimes the large congregation should be broken into sections. ${ }^{4}$ she stated that "at times, greater good can be accomplished" by this, since "the educator in Bible truth can come closer to the people than in a large assembly." 5

5. Need for security. Secular people have another need--a need for certainty and security. ${ }^{6}$ It seems that people in the Euro-Asia Division certainly do have this need. Economical instability, poor living conditions, and

${ }^{1}$ Paulien, 129, 132 .

2 T. Ed Barlow, Small Group Ministry in the Contemporary Church (Independence, MO: Herald Publishing House, 1972), 75.

3 Ibid. , 76 .

${ }^{4}$ Ellen G. White, Gospel Workers (Boise, ID: Pacific Press Publishing Association, 1948), 407.

${ }^{5}$ Ibid.

6 Oosterwal, 59. 
political insecurity do not make 1 ife for the multitudes there very easy. Results of a questionnaire published in the popular Russian magazine Ogonek show that $49 \%$ of those who were asked believe that $\mathrm{I}$ ife would be better if everything in the country stayed as it was before 1985; 43\% can hardly make ends meet, and $8 \%$ are 1 iving under the 1 ine of poverty. To the question, "What issues are of primary importance for your family?" 43응 answered: "to have much money"; 41\%--"to have an apartment"; 40\%--" to eat well." 1 This shows that the primary needs of the people there are survival needs. The complex crime situation ${ }^{2}$ also adds to the need of security.

New believers turn to God in hope of receiving help. He can surely give it through His people. Many believe today that it is of crucial importance to meet people where they are: first, to minister to their felt needs; and then, to lead them towards the ultimate ones. ${ }^{3}$ This was Christ's method to approach people, 4 and modern psychology supports

1"Rossijskaya Politika: Opros BTZIOM" ("Russian Policy: Survey by Center of Studies of Public Opinion"), Ogonek 49 (1995): 17 .

${ }^{2}$ Vladimir Kolesnikov, "Kriminalnaya Obstanovka v Rossii krajne napryazhennaya" ("Criminal Situation Is Extremely Intensive in Russia"), Ogonek 52 (1995): 26-27.

3 Mark Finley, Padded Pews or Open Doors (Boise, ID: Pacific Press, 1988), 28-29.

${ }^{4}$ Ellen $G$. White, The Ministry of Healing (Mountain View, CA: Pacific Press Publishing Association, 1942), 143. See also Philip G. Samaan, Christ's Way of Reaching People 


\section{9}

its efficiency. The physical needs of people should be met before they can feel safe in a physical sense, and their psychological needs also should be met for their emotional security. 1

However, it is incredibly hard to know all the personal needs of every member in a large congregation. "There are hurting people who feel alone in a crowded church. They have personal needs and concerns that can only be addressed when we are open enough to come close to them and to exercise the gift of compassion." 2 House churches make it easier to come close to the people, know their needs more, and help them.

Home Churches and the Needs in Relation to People

Secular people also have needs in relation to others. They may come to the church hoping to satisfy those needs there.

(Hagerstown, MD: Review and Herald Publishing Association, 1990).

${ }^{1}$ See A. Maslow's hierarchy of needs. "At any given step in the hierarchy there must be a degree of satisfaction before the individual is motivated to satisfy the next level." Paul D. Meier, Frank B. Minirth, Frank B. Wichern, and Donald E. Ratcliff, Introduction to Psychology and Counseling (Grand Rapids: Baker Book House, 1991), 88-90.

${ }^{2}$ Craig A. Dossman, Sr., From House to House (Lincoln, NE: Baby Boomer Ministries Resource Center, 1994), 34. 
1. Need for meaningful relationships. One of the relational needs of secular people is a need for meaningful relationships. 1 Some also call this need a need for fellowship ${ }^{2}$ and deeper relationships. 3

With the increase in the population, and especially in urban areas, modern man becomes very lonely. As Wolf says, "surrounded by millions, he knows very few"; "the somebody of the small town is another nobody in the urban center." 4 There is an interesting phenomena: an increase of geographical proximity among people in cities at the same time brings relational and emotional isolation from each other. 5 In addition, people begin to deal more and more with machines than with people. They "pull the world closer electronically but push us apart personally." 6 This results in impersonalization of the society. ${ }^{7}$ As Fidley B. Edge expresses it figuratively, in cities "we are like worms in a

${ }^{1}$ Paulien, 130 .

2 Oosterwal, 59 .

3 Dossman, 47 .

${ }^{4}$ Wolf, $159-160$.

5 Findley B. Edge, "Introduction" in William Clemmons and Harvey Hester, Growth through Groups (Nashville, TN: Broadman Press, 1974), 13.

${ }^{6}$ David R. Veerman, Small Group Ministry with Youth (Wheaton, IL: Victor Books, 1992), 15 .

${ }^{7}$ Edge, 13 . 
can, crawling all over each other but never touching one another." 1 Paulien expresses this idea in the following words: "As society becomes increasingly high-tech, the need for genuine relationships will increase. There will be a corresponding need for caring touch, not so much physical as emotional and social." 2

It is obviously impossible for members to personally know everyone in a church of several hundred people. It is so easy for a person to become just a name on the membership list. 3 James Cress states that new members often lose their former friends or suffer abandonment from them. 4 They often become even more lonely than common secular people. Research shows that "each member needs a minimum of seven individuals whom he or she considers their friends. Each person also needs someone, preferably more than one, who is considered a special friend." 5 Furthermore, if this does not happen, there is a high risk of apostasy. 6 In this situation, friendships and fellowship that can bind new

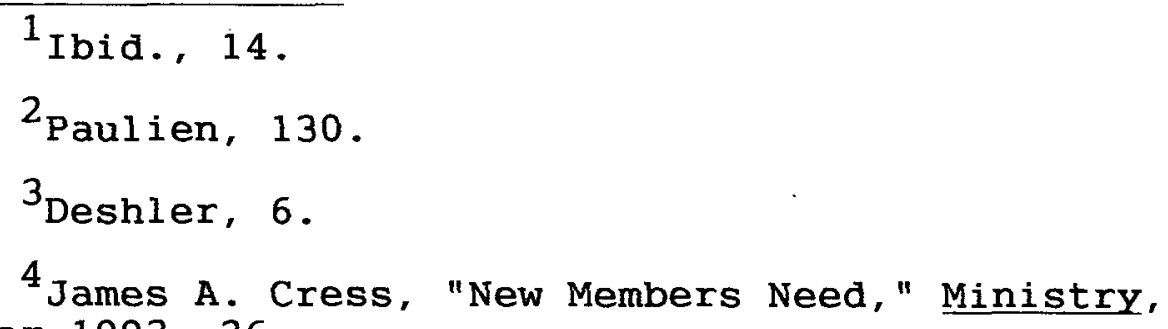
December 1993, 26 .

${ }^{5}$ Kurt Johnson, Small Group Outreach (Hagerstown, MD: Review and Herald Publishing Association, 1991), 31.

${ }^{6}$ Ibid. 
believers to the church are greatly needed. "Small groups that include established members as well as new members are an excellent way to built new friendships." 1 In an impersonal world, such groups can become "the place where everyone knows your name." 2

2. Need for communication. There is also another need, that of deeper communication or, in other words, a need "to be 1 istened to and heard." 3 Modern 1 ife presses a contemporary person to interact daily with a lot of people he or she will not necessary be close to in the future. This brings a habit of superficial relationships and hidden self. 4

Furthermore, many people in modern society devote hours to watching TV programs, which also "decreases time spent in conversation, activity and personal relationships." 5 It educates a person to be an observer rather than an active participant. 6

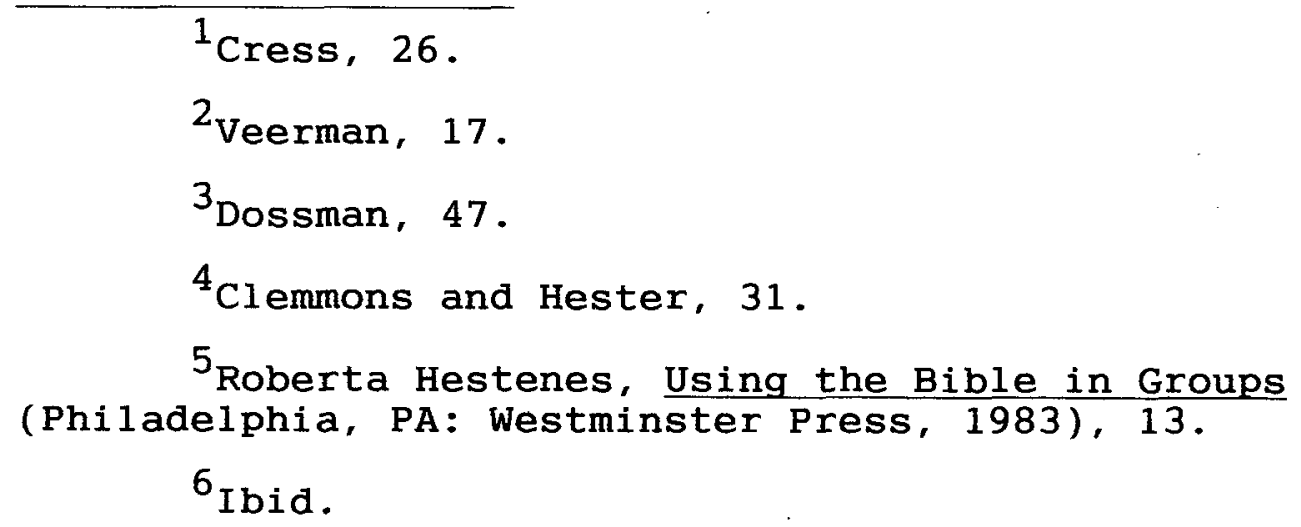


Big churches tend to project the same superficial communication and isolation of individuals, ${ }^{1}$ with the majority of the members as listeners. Many of them become so used to it that they even feel threatened when opportunities for communication arise. However, to leave everything as it is in the churches means to educate the majority of members to be passive, self-closed, and thus, often unheard and unhealed. In addition, people can never grow significantly if they do not express themselves. As Veerman states,

But how can they find answers if they don't ask questions? How can they find direction if they don't admit they're lost? How can they find solutions if they don't face up to their problems? How can they find help if they don't share their needs? ${ }^{2}$

Thus, there should be an opportunity and proper surroundings where members can exchange spiritual ideas, be listened to, and grow. It is hard to imagine that someone could be so brave, "admitting a drug problem in a large meeting, or expressing serious doubts about God." 3 Instead, small groups are more conducive for this. It is interesting that self-disclosure is named as a possible cure for impersonalization, loneliness, mobility, etc., of a modern

\footnotetext{
${ }^{1}$ Schilt, 28-29.

2 Veerman, 18 .

${ }^{3}$ Ibid., 17-18.
} 
person. 1 "Spiritual growth, like emotional and mental growth, doesn't take place in a vacuum: It is fostered and enhanced by interaction." 2

3. Need for an extended family ${ }^{3}$ and community. 4 Today people more and more experience this need in the world where migration of the population brings rootlessness. As Clemmons says, people lose the connection with their roots and a family circle, where different age groups bring their positive contribution in unexpected crises. 5 Paulien, addressing this issue, shows that the church can replace this loss. 6 The only question is, what kind of church? Obviously, it should be small enough to create family ties. Many of the new converts in the Euro-Asia Division are in a very complex situation. The majority of them have been converted separately from their families. Thus, the conversion has divided family circles and relationships with relatives and friends. The newcomers expect the church to meet this need for extended and primary family. Community

${ }^{1}$ Clemmons and Hester, 32-33.

$2 \mathrm{Jim}$ Plueddemann and Carol Plueddemann, Pilgrims in Progress: Growing through Groups (Wheaton, IL: Harold Shaw Publishers, 1990), 80 .

${ }^{3} \mathrm{Clemmons}$ and Hester, 31-32, 41.

${ }^{4}$ Oosterwal, 59. See also Dossman, 47 .

${ }^{5} \mathrm{Clemmons}$ and Hester, 31-32, 41.

${ }^{6}$ Paulien, 130-131. 
for them becomes vital just as it was for the early

Christians, who "were isolated from and persecuted by society." 1 Roberta Hestenes shows the advantage of small groups in building a community with strong bonds:

A large worshiping community without some type of small group involvement risks developing a fellowship which is friendly and polite on the surface but which may not discover the rich resources that arise from the membership being more deeply involved with one another.

4. Need for identity. Secular people are also in a quest for their identity. 3 For years people have been pushed to achieve important goals, but after the 1970s a shift occured: people began to search for their roles rather than just be interested in achieving some goals. 4 In regard to the church, people want to know not only how to become a member but also how to be a member. A role implies some functions; in other words, activities. To be satisfied with a new role, a person should live it and be successful. This coincides with other needs of a secular people: "to be appreciated and respected," and "to have practical help in

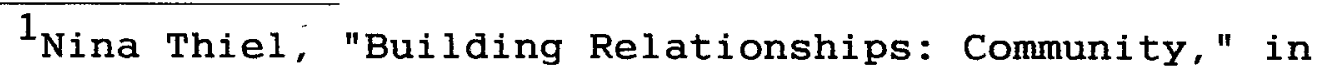
Sma11 Group Leaders' Handbook: The Next Generation, ed. Jimmy Long (Downers Grove, IL: InterVarsity Press, 1995), 40 .

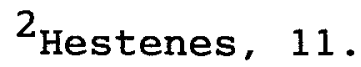

3 Oosterwal, 59 .

${ }^{4}$ Clemmons and Hester, 32 . 
developing a mature faith." 1 Creath Davis says that every person needs "at least one relationship which allows and encourages the unfolding of his unique personality." 2 Thus, new members cannot do it alone. They need a support group to live a life of a church member, and its guidance in order to be a successful one.

The results of the questionnaire on apostasy of members in the Euro-Asia Division show that the members see two major reasons for it: new converts did not form meaningful relationships with God, or with other believers. However, many of the old members have the same needs that also are unmet. The process of secularization has enveloped not only those who are outside the church but those who are inside as well. 3 Since people in the church live in the same challenging world, they often find themselves with the same needs as people in secular society. Sometimes, they feel even worse because of the failed expectations. Many families experience a lack of communication and understanding due to the demands of a stressful modern life. ${ }^{4}$ In addition, there is a trend in

${ }^{1}$ Dossman, 47 .

${ }^{2}$ Creath Davis, Sent to Be Vulnerable (Grand Rapids: Zondervan Publishing House, 1973), 52.

3 Oosterwal, $42,45,56$.

${ }^{4}$ Larry Adam Alb, "Developing a Small Group Ministry for Church Renewal and Growth" (D.Min. dissertation, Fuller Theological Seminary, 1986), 54 . 
religion to become conceptual rather than personal. ${ }^{1}$ Thus, the churches are full of believers who are often hurt, insecure, lonely, and hungry for more meaningful relationships with God. ${ }^{2}$ They are looking for new meaning to their lives, searching for new roles, and struggling to survive with this new identity. Then, reevaluating, they ask the questions, "How does it function? Does it work in my life?" 3 The truth continues to be relevant to them only if they can feel its power in their personal lives.

It seems that a small-group approach can better meet these needs than the traditional congregation. It helps to satisfy these two basic groups of needs: needs in relation to God and needs in relation to other people. To recognize this is crucially important for the church in the Euro-Asia Division, since as Ervin R. Stutzman notes, "It has been said that persons join a church for many reasons, but they stay for only one reason--relationships." 4

\section{Challenge of the Lack of Pastors}

It is evident from the first chapter that another challenge of the Division is the deficiency in pastors.

\footnotetext{
$1_{\text {Edge, } 14-15 .}$

${ }^{2}$ Clemmons and Hester, 33-34.

${ }^{3}$ Oosterwal, 50-51.

${ }^{4}$ Stutzman, 96 .
} 
Nevertheless, as the results of the questionnaire show, this demand is not perceived by the pastors and lay members of the Division as a major reason for apostasy. Instead, absence of such pastoral functions as home visitations and knowledge of personal needs was considered as more significant. In other words, it is not so much the lack of pastors that causes the problems as the lack of pastoral care.

Michael Green shows the significance of after-baptism care in the following words: "After-care is as vital as birth. If not cared for, the new babe in christ will starve." 1 E. White also stresses this necessity: "The zeal of many ministers seems to fail as soon as a measure of success attends their efforts. They do not realize that these newly converted ones need nursing--watchful attention, help, and encouragement." 2 Although some may perceive the reasons of apostasy as primarily results of pastoral neglect, the problem in the Euro-Asia Division is in the insufficient numbers of pastors rather than in the neglect of pastoral duties. Then, the question is, can pastoral care be provided by some other means?

\section{${ }^{1}$ Michael Green, Evangelism--Now and Then (Leicester,} England: InterVarsity Press, 1979), 81 .

${ }^{2}$ Ellen G. White, Testimonies for the Church, 9 vols. (Boise, ID: Pacific Press Publishing Association, 1948), $4: 68$. 
It seems that the SDA church already has an answer, which is laymembers' involvement. E. G. White makes this point very clear in different places of her writings.

No wonder that some become discouraged, linger by the way, and are left for wolves to devour. . . . There should be more fathers and mothers to take these babes in the truth to their hearts, and to encourage them, to pray for them, that their faith be not confused.

She makes it clear that those who are not working for God gradually become employed by Satan. Nobody can expect anything but "deterioration in religious life when the people listen to sermon after sermon and do not put the instruction into practice." 2

The Barna Research Group reports in Successful Churches: What They Have in Common that, among other characteristics, "successful churches invariably had a strong pastor." 3 However, these "pastors of successful congregations had enough confidence in themselves as leaders that they believe the only way they could flourish was by getting others to take responsibility." 4 They became "a manager of people rather than a line worker." 5

1 Ibid.

${ }^{2}$ Ibid., 6:425.

${ }^{3}$ Successful Churches: What They Have in Common (Glendale, CA: The Barna Research Group, 1990), 35.

${ }^{4}$ Ibid. , 36 .

5 Ibid. 
E. G. White uses the illustration of an army to demonstrate the importance of every member's involvement in the work of the church: "All who have enlisted as His soldiers are to render faithful service as minutemen, with a keen sense of the responsibility resting upon them individual $1 \mathrm{Y} \cdot 1$

The strength of an army is measured largely by the efficiency of the men in the ranks. A wise general instructs his officers to train every soldier for active service. He seeks to develop the highest efficiency on the part of all.

The leaders in God's cause, as wise generals, are to lay plans for advance moves all along the lines. In their planning they are to give special study to the work that can be donȩ by the laity for their friends and neighbors.

Small groups are such places where "soldiers" can be instructed and involved in caring for the needs of members. Pastoral care can be provided in marvelous ways through this approach. It is interesting to note that E. G. White saw a necessity in the development of special methods providing more efficiency for lay involvement.

Those who have the spiritual oversight of the church should devise ways and means by which an opportunity may be given to every member of the church to act some part in God's work. Too often in the past this has not been

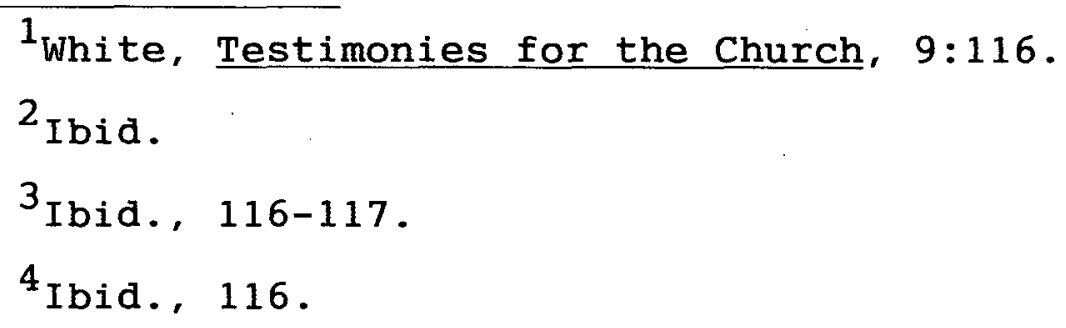


Dale Galloway, a pastor of New Hope Community Church in Portland, Oregon, who grew his congregation from 50 people in 1972 to 6,100 worshippers in 525 small groups in 1992,1 shares his pastoral experience in relation to this matter:

No church over 100 members can be effective in pastoral care without enlisting and enabling the lay people in the day-to-day pastoral care. . . Our pastoral staff painfully recognized that the people who never get involved in one of our Tender Loving Care groups are the ones that we have the most difficulty in caring for. Our highest percentage of membership loss comes from $_{2}$ those who never get into one of our TLC groups. 2

\section{Challenge of the Lack of Church Buildings}

It is obvious from the previous chapter that the Euro-Asia Division is presently facing a great need in church buildings. It is true that the church is people, not buildings. This concept, alongside the side effects of institutionalism, has led some people to undermine the advantages of possessing a church building. ${ }^{3}$ However, in

${ }^{1}$ Karen Hurston, Growing the World's Largest Church (Springfield, MO: Gospe1 Publishing House, 1994), 204 .

2 Dale E. Galloway, $20 / 20$ Vision. How to Create A Successful Church (Portland, OR: Scott Publishing Company, 1986), 143. For further reading on laymembers' involvement in the church work see Oscar E. Feucht, Everyone a Minister (St. Louis, MO: Concordia Publishing Hpuse, 1974); Douglas R. Kilcher, "The Minister as an Equipper," in The Adventist Minister, ed. C. Raymond Holmes and Douglas R. Kilcher (Berrien Springs, MI: Andrews University Press, 1991), 99108; Melvin J. Steinbron, Can the Pastor Do It Alone? (Ventura, CA: Regal Books, 1987).

$$
3_{\text {Krupp, 57-58. }}
$$


reality, people need some place to identify with. It is the same situation as with a family: a family is a family whether it has a place to live in or not. Nevertheless, it has a better chance to develop great relationships and to create a home if it has its own private place.

This happens to be the same situation with the lack of church buildings in this Division. Difficulties connected with rented halls differ from place to place, but it is evident that the possession of a church building remains desirable by every congregation.

E. G. White says the following regarding this matter: "Wherever a company of believers is raised up, a house of worship should be built. Let not the workers leave the place without accomplishing this." 1 Her point is that new converts who become members of a congregation without a church building are often admonished by others with following words: "These people have no church, and you have no place of worship. You are a small company, poor and unlearned." 2 These people also tell new believers that "in a short time the ministers will go away, and then the interest will die down. Then you will give up all these new ideas which you have received." 3

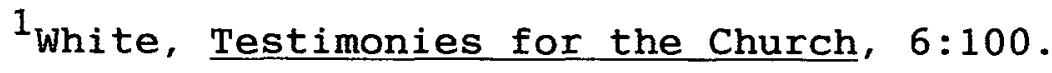

2 Ibid.

3 Ibid.
} 
This can be especially true in the context of Russian culture where, traditionally, the orthodox church is rich with beautiful cathedrals. E. G. White advises us not to follow their expensive way but to build "humble. sanctuaries." 1 However, she adds that a church should be built with "as much greater interest, care, and taste in its arrangement as the object for which it is prepared is higher and more holy than that for which common dwelling houses are prepared." 2 Thus, new converts "may find a place to worship God according to the dictates of their own conscience." 3

She also points out that the church members should participate in building the church "with their own hands." When it is impossible for a new group of believers to erect the church, members from other churches should help. She maintains that it is better for a church to build a house for worship free of debts. Nevertheless, she considers this need so crucial that "in some cases it may be better to hire some money than not to build." 4

One who has visited several congregations in the Euro-Asia Division that are gathering in rented public halls can attest to the great wisdom of this advice. Many of the

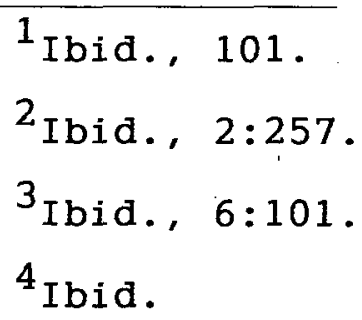


members from this Division would agree with Ellen White's description of a tent meeting in 1874: "Had there been a pleasant and commodious house of worship there, more than double the number that were really gained would have taken their stand for the truth." 1

Since a small-group approach is suggested as an addition to the common once-a-week gathering on Sabbath, it cannot fully meet the need for church buildings in this Division. Plans for the erection of churches obviously should be laid out and carried on. However, home churches can play a crucial role in this situation. They can provide a sacred environment for worship, which is missing in the majority of public halls, and they can provide opportunities for each member to pray, share testimonies, and express requests. A home church can also create a bond between the believers that the public hall cannot provide. In this way, they will be united, their identity as church members developed, and their care for each other enforced. It has been said that there is a lot of loneliness among members in the large congregation. In a large public hall, it is even easier to feel lost. Visitors as well as members themselves are often overlooked. Home churches will surround these people with a warm atmosphere and encourage them to bring their relatives and friends to small-group meetings. In

$$
{ }^{1} \text { Ibid., } 4: 67 \text {. }
$$




\section{5}

these meetings, opportunities for social events and deeper interaction will be provided. Thus, if small groups are needed anywhere, they are definitely needed in such places where congregations do not have their own church buildings. Although home churches cannot solve the challenge of the lack of church buildings in itself, they will solve the deficiencies created by this challenge.

\section{Challenge to Reach the Unreached}

There is another challenge in the Euro-Asia Division: millions are unreached by the three angels' message. This section shows why small groups can be an effective means for reaching primary circles of believers, followers of nonChristian religions, and the people in urban settings.

\section{House Churches as an Effective Means for Reaching Primary Circles of Believers}

Every person is a member of some kind of small group that is created by him, his relatives, friends, and associates. This group can be called a primary circle of relationships, which reflects the deep meaning of the Greek word oikos. ${ }^{1}$ often conversion breaks the relationships of

\section{$1_{\text {Michael Green, in Evangelism in the Early Church }}$} (London: Hodder and Stoughton, 1970), 210, shows that for the early Christians the word household--oikos--represented a family in a broad sense, including blood relatives, slaves, friends, and clients. Ralph Neighbour, Jr., with Lorna Jenkins, in where Do We Go from Here? A Guidebook for the Cell Group Church (Houston, TX: Touch Publications, 1990), 249, defines it as the family of a person along with his friends and business contacts. Win Arn and Charles Arn, 


\section{6}

a new converts with his or her oikos. Gradually, they become strangers there unless active evangelistic efforts are made.

From the missionary point of view, such a situation is a very good opportunity for outreach. Michael Green states that evangelism in the Early Church was primarily flourishing through the oikos of believers. ${ }^{1}$ Win Arn and Charles Arn show that webs of such relationships "are still the paths most people follow in becoming Christians today." 2 They show that there are several reasons why this method is a very effective one. It provides "the most natural place" to share faith with people who are usually "receptive" since they already know and trust the witness. Additionally, it allows people to be converted without a rush, providing natural support and assimilation. Furthermore, evangelism through oikos tends "to win entire families" and "provide a constant enlarging source of new contacts." 3

Ralph Neighbour shows that winning a household was a goal of Jesus' strategy, when He sent His disciples in pairs

in The Master's Plan for Making Disciples (Pasadena, CA: Church Growth Press, 1982), 43, give a definition of "common kinship (the larger family), common friendship (friends and neighbors) and common associates (special interests, work relationships, and recreation)." See also, ibid., 38-41.

${ }^{1}$ Green, Evangelism in the Early Church, 210.

${ }^{2}$ Arn and Arn, 43.

3 Ibid. , 45-53. 
on a missionary journey (Luke 10:1-9). These disciples were "to find a person who will bring them into his oikos." 1 "They are "fishing" for a special type of person, called "a man of peace." 2 Neighbour argues that this is a good strategy for an outreach through small groups in our century too, namely, to target an oikos. ${ }^{3}$ He suggests that each member of a group write "a list of all the people he or she talks to for a total of one hour in seven days," since they mainly represent his oikos. ${ }^{4}$ The next step is to divide the list into two groups--believers and unbelievers--and make the latter group "the primary mission field." The last step is to write the names of those who are in the secondary oikos. He says that "many people are surprised to discover that they actually have natural connections with as many as one hundred individuals. These people should be the first to be reached and brought into the share group." 5

Thus, evangelism through oikos is a very natural and successful outreach. However, it can be more easily developed and implemented through small groups than through

\footnotetext{
${ }^{1}$ Neighbour, Where Do We Go from Here? A Guidebook for the Cel1 Group Church, 250.

2 Ibid.

3 Ibid., 251 .

${ }^{4}$ Ibid., 257.

${ }^{5}$ Ibid.
} 
personal efforts of individuals in a large congregation. This is so because a new convert, first of all, needs support by himself. Sometimes, his oikos can be prejudiced rather than receptive, especially when he joins a nontraditional church with the foreign name "Adventist" in the Orthodox environment. He needs instructions and intercessory prayers of other members of the church. Often he also needs progressive spiritual growth in order to model the right example for those he wants to convert. As Gordon Cosby puts it, "We try to send into the world healers who have not themselves been healed." 1 He adds, "I believe that if the Church is to be effective on the outward journey, it is essential to begin at the point of the inward journey." 2 Thus, it is easier for a new member to become an evangelist for her oikos if she belongs to a supportive group that stands beside her.

Additionally, people from a new beliver's primary circle may be interested in becoming acquainted with some of his or her friends. It will be unfortunate if such people can be found just for an evangelistic talk and then will disappear. It will be better if new members can bring in their oikos those who became their new Christian friends.

$1_{N}$. Gordon Cosby, "Inward Journey," in Groups that Work, ed. Walden Howard (Grand Rapids, MI: Zondervan Publishing House, 1967), 59.

2 Ibid. 
Furthermore, oikos of the church members often are made up almost exclusively of Christians, 1 people from the same Christian background and the same church. Joining missionary-oriented small groups, church members can first be involved in helping other members of the group to reach their non-Christian oikos. As Peace suggests: "Your training group will split into two or three subgroups, each of which will plan and execute its own small group outreach program." 2 second, their vision can be opened, and they can start to find their secondary oikos, consisting of nonChristians.

It is interesting that E. G. White also showed the primary importance of starting outreach from your own place:

Let those who desire to work for God begin at home, in their own household, in their own neighborhood, among their own friends. Here they will find a favorable missionary field. This home missionary work is a test, revealing thȩir ability or inability for service in a wider field.

Thus, home churches can provide an excellent setting to nurture, heal, instruct, and support those who are called by God to become evangelists in their primary circles. They can become a second family for converts from oikos and

${ }^{1}$ Richard Peace, Small Group Evangelism: A Training Program for Reaching Out with the Gospel (Downers Grove, IL: InterVarsity Press, 1985), 71 .

2 Ibid., 126.

3 White, Testimonies for the Church, $6: 428$. 
provide excellent post-baptismal care and needed follow-up. In addition, a home-church approach involves every member of the church in active evangelism and opens unlimited possibilities to convert great numbers of people through the most natural ties.

\section{House Churches as an Effective Means for Reaching and Assimilating Followers of Other Non-Christian Religions}

It was mentioned in chapter 1 that there are Buddhists, Shamanists, Muslims, and other non-Christian religious groups in the Euro-Asia Division. Muslims represent the largest one, occupying about 30 percent of its territory and comprising over $57 \mathrm{million}$ people. ${ }^{1}$ As some sources state, the high birthrate in Muslim families will help them to outnumber native Russians in several decades. 2

The challenge to reach these groups of people is even more complex since one of their peculiarities is that they are community-oriented people. Every Muslim, for example, "is part not only of the family but of the whole nation of Islam." 3 Conversion to the Christian religion brings a lot of changes in a new believer's life. It excludes him from

${ }^{1}$ George Otis, 174 .

2 Ibid.

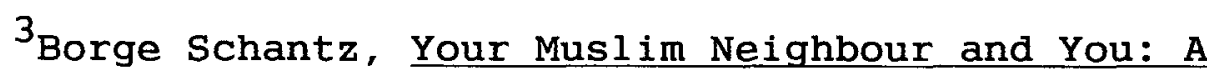
Manual for Personal Evangelism (Bracknel1, Berkshire: Seventh-day Adventist Global Centre for Islamic Studies, 1993), 21 . 
the closely connected Islamic community and from "occasions for communication" in mosques. Instead of "five times daily fellowship" he has a "once a week church service." 1 He lives with a threat of alienation and even death, ${ }^{2}$ an enemy in his or her own home, and often a lone stranger in the Christian church. Thus, it is extremely important "that converts from Islam, cut off as they probably will be from their Islamic community, be received as beloved members of a Christian church." 3 Schantz stresses the fact that after baptism frequent contacts and supportive care are very needed for a Muslim convert. 4

In addition, as Gordon Hadley states, "Muslims are very perceptive. They watch your personal life." 5 He says that although very moral, Muslims are missing love. Thus, they need to see the relationships in Christian families, among Christian members, their attitudes toward moral

$1_{\text {Ibid., } 26 .}$

2 Ibid.

$3_{\text {William Miller, A Christian's Response to Islam }}$ (Nutley, NJ: Presbyterian and Reformed Publishing Co., $1976), 141$.

${ }^{4}$ Schantz, 27 .

${ }^{5}$ G. Gordon Hadley, "The Medical Work in Relation to Islam," in The Three Angels and the Crescent, a Reader: Adventist Approaches to Islamic People, ed. Jonquil Hole and Borge Schantz (Bracknell, Berkshire: SDA Global Centre for Islamic Studies, 1993), 206. 
issues, and "whether people are happy or not." 1 Michael Griffiths argues that this is the same issue for followers of the other Eastern religions:

Determination to touch the heart and establish empathy and to build real friendships is basic. No amount of talk about what Jesus can do will avail unless people can see evidence of what He has actually done in our lives. This requires great patience in establishing mutual confidence and providing opportunity and time for the seeker after truth to see the reality of Jesus Christ working in our lives through His Holy Spirit.

Thus, true Christianity with genuine love is required for these people. Care and social work should not become just "a means to a soul winning end" but "an end in itself." 3 Then, they can be convinced. The christian church should be interested in providing surroundings where such missionaries can be raised and acts of love can be shown toward non-Christians. Small groups are a good place to do this, since "in a cell group, the focus is placed on personal growth with a motive--winning the lost." 4

Neighbour divides all unbelievers into two major categories: type "A"--the "like us" unbelievers, easily

${ }^{1}$ Ibid., 202.

2 Michael Griffiths, "Eastern Religions," in How Shall We Reach Them? ed. Michael Green and Alister McGrath (Nashville, TN: Thomas Nelson Publishers, 1995), 124.

${ }^{3}$ Schantz, 25 .

${ }^{4}$ Neighbour, Where Do We Go from Here? A Guidebook for the Cell Group Church, 239. 
reached, who already have some information about God ("these people are reached through visitation" ${ }^{1}$ ) and type "B" --"hidden" people, "needing cultivation." They do not believe or understand Bible truth. "There must first be a time of developing relationships--exposing them to the reality of the living Christ in our own lives. . . These people are reached through share groups!" 2 While the first type is open to the message, the second one is open to the messenger. 3 A majority of the followers of other nonChristian religions represent type "B". Key words in reaching them are messenger, relationship, love, care, and share groups.

It is important to note that oikos evangelism can be a successful approach in reaching these people. First, a receptive person should be found. Much can be done through woman-to-woman relationships, since for a Muslim woman "visits and conversations with other women are allowed." 4 Then, relationships with the primary oikos can be established. The key is to "discover who is the opinion-

$$
1_{\text {Ibid. . } 244}
$$

2Ibid., 244-245. Type "B" is divided by this author into two categories: "aware, but not receptive. Two problems: does or doesn't know a Christian. No awareness of the gospel. 'Baptist or Buddhist--different roads to the same place!" "

$$
\begin{aligned}
& { }^{3} \text { Ibid., } 245 . \\
& { }^{4} \text { Schantz, } 21 .
\end{aligned}
$$


maker in the group, and befriend that person." 1 "The best option of course would be to present Jesus to the family leader and influence that one to accept Christianity. Then the rest of the group would follow more easily." 2

Since usually such people are reluctant to visit Christian churches, house churches can be an appropriate place to invite them for the first time. A small circle of people provides a sense of community, especially if some members of it have already become friends with the invited person. A simple meal can be shared, which is important in such cases, because "in Islamic cultures, sharing a meal is a token of acceptance and friendship." 3 Meaningful information about the person can be gained, and new relationships with other members established. But what is even more important than this first meeting in a home church is the fact that its members will not leave this person alone. They will become a second family for him. And this he will surely need in his Christian journey.

House Churches as an Effective Means for Reaching Urban Populations

The Adventist church in the Euro-Asia Division comprises less than 1 percent of the total population. In

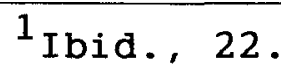

2 Ibid.

3 Ibid., 20. 
addition to many challenges, there is yet another one: how to reach people in growing cities. Even in 1970 the urban dwellers comprised 57.1 percent in the territory of the former Soviet Union. ${ }^{1}$ Increasingly, growing cities are becoming "the new frontier of missions." 2

Pointing to the future challenge of the world explosion of urban populations and the evangelism potential of small groups, Neighbour states:

More and more, we are recognizing that Christ's greatest untapped resources are church members who have never been adequately discipled, trained, or challenged to become evangels of the gospel in their own neighborhoods. Important, indeed, to an effective urban strategy, is the plan to train large numbers of the laity.

He argues that traditional patterns of ministry, "which centered around revivals, buildings, and 'pack-thepew' campaigns", will not be successful in the urban tomorrow. ${ }^{4}$ He suggests that "a new type of church that can think in terms of multiplication, not addition, "should be planted. 5

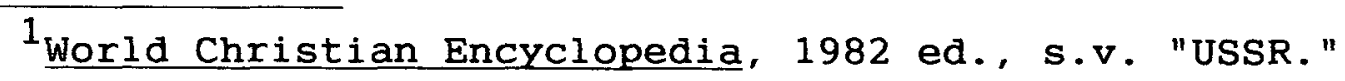

2 Bruce C. Moyer, "The Challenge of the Cities," Ministry, November 1992, 26.

${ }^{3}$ Ralph W. Neighbour, Jr., "The Urbanization of the Earth," in Future Church, ed. Ralph W. Neighbour, Jr. (Nashville, TN: Broadman Press, 1980), 15.

\footnotetext{
4 Ibid., 16.

$5_{\text {Ibid. , } 13 .}$
} 
Hundreds of evangelistic campaigns in the territory of this Division have proved to be good although not so effective devices. In addition, an interest towards evangelistic campaigns is gradually declining. It seems that something else needs to be done to penetrate the masses with the Adventist presence.

E. G. White shows that house-to-house labor is of equal importance with public work. "In large cities," she states, "there are certain classes that cannot be reached by public meetings. These must be searched out as the shepherd searches for his lost sheep." 1 she points out that through this house-to-house work, a ministry to "the lowly, the poor, and the oppressed" can be made. "Many can be reached only through acts of disinterested kindness. Their physical wants must first be relieved. As they see evidence of our unselfish love, it will be easier for them to believe in the love of Christ." 2

Wolf argues that in response to his loneliness, survival difficulties, and rootlessness, urban man is listening. ${ }^{3}$ Radio and television reach millions and educate people to be listeners. "In all six continents, the

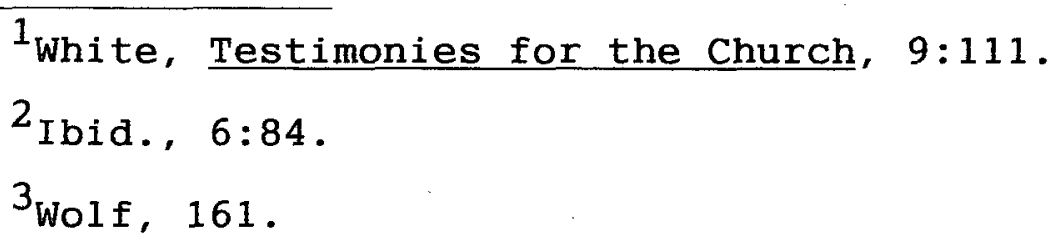


rootless are responsive." 1 wolf says the results of studies show that, "for the first ten to fifteen years after arrival, the urban newcomer is especially open to new ideas, including the gospel." 2 He concludes that the solution for the challenge of reaching an urban population is oikos evangelism, the same method that helped the Early Church to grow rapidly. "Oikos evangelism won the urban centers of the first church. And oikos evangelism will win the cities of the future church. Oikos evangelism: God's key to the future. " 3

Interestingly enough, E. G. White also writes about this home-to-home work as a special method devised by God to reach urban dwellers:

The Lord has presented before me the work that is to be done in our cities. The believers in these cities are to work for God in the neighborhood of their homes. They are to labor quietly and in humility, carrying with them wherever they go the atmosphere of heaven.

As shown above, home churches are an effective approach to mobilize lay members for the work in their oikos and neighborhoods. This approach has a great potential for reaching the urban population with even greater results than
${ }^{1}$ Ibid.
2 Ibid., 161-162.

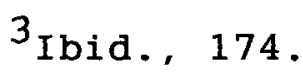
${ }^{4}$ White, Testimonies for the Church, 9:128. 
public evangelism. The example of David Yonggi Cho, ${ }^{1}$ a pastor of the world's largest church in Seoul, Korea, proves it. Starting with 2,400 members in $1964,{ }^{2}$ he had 18,000 in $1973^{3}$ and 700,000 members in 1993.4 That year he expected to have about 100,000 new converts. ${ }^{5}$ His method of evangelism is very simple, as he views it:

We have 50,000 cell groups, and each group will love two people to Christ within the next year. They select someone who's not a Christian, whom they can pray for, love, and serve. They bring meals, help sweep out the person's store--whatever it takes to show they really care for them.

When the person asks, 'Why are you treating me so well?' our people answer, 'Jesus told us that we're supposed to do good to all men, and we want you to know that we love you, and so does Jesus.' After three or four months of such love, 6 the hardest soul softens up
and surrenders to Christ.

It sounds very much like the advice of E. G. White, who urged lay members to become involved in personal evangelism through acts of love:

By personal labor reach those around you. Become acquainted with them. . . Money lent or given will not

${ }^{1}$ Paul Yonggi Cho, renamed himself into David Yonggi Cho in 1992, see Carl F. George with Warren Bird, The Coming Church Revolution: Empowering Leaders for the Future (Grand Rapids, MI: Fleming H. Revell, 1994), 93.

2 Paul Yonggi Cho; Successful Home Cell Groups (Plainfield, NJ: Logos International, 1981), 4.

$$
\begin{aligned}
& { }^{3} \text { Ibid., } 43-44 . \\
& { }^{4} \text { George, } 93 . \\
& { }^{5} \text { Ibid., } 93-94 . \\
& { }^{6} \text { Ibid., } 94 .
\end{aligned}
$$


accomplish it. Sermons will not do it. By visiting people, talking, praying, sympathizing with them, you will win hearts. This is the highest missionary work that you can do. 1

Christ's example must be followed by those who claim to be His children. Relieve the physical necessities of your fellow men, and their gratitude will break down the barriers and enable you to reach their hearts.

Finley, an experienced evangelist of the SDA church,

shares the same perspective:

I know this for sure. If church members are sensitive, loving, caring individuals looking for opportunities to help meet the felt needs of their friends, the walls of prejudice will break down. Closed minds will open. Opportunitiȩs will present themselves for us to share the gospel.

Urban people are, in general, secular. 4 As was presented above, they have special needs in relation to God and to other people. Since the home-church approach is a good method to meet those needs, it seems very reasonable to use it for outreach and assimilating in urban settings.

Hunter says that "church leaders, who know that many secular people are alienated from their neighbors, promote small groups, including support groups for seekers." 5 He also points to oikos evangelism as one way to reach secular

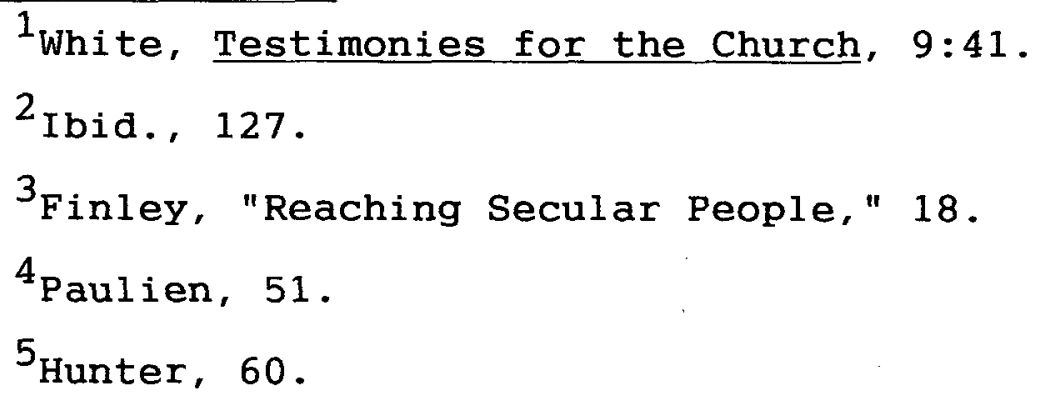


people: "Secular people can be reached better by credible Christians in their kinship and friendship networks than by Christian strangers." 1 Finley states that "personal evangelism is still the best way to win secular people." 2

Thus, home churches can be a possible solution to the challenge of reaching an unreached urban population.

\section{Summary}

The Euro-Asia Division is presently facing several great challenges: the apostasy of new converts, the lack of pastors, the lack of church buildings, and multitudes of unreached people.

The home-church approach is suggested as a possible solution to these challenges. It does not necessarily exclude all other methods of work, although it seems to be much more effective in that setting than all other approaches.

One of the greatest challenges is the apostasy of converted people during an era of public evangelism. There are two major reasons for apostasy, as seen by the church in the Euro-Asia Division: the people have not built personal relationships with God and not formed personal relationships with other church members. Studies show that these two

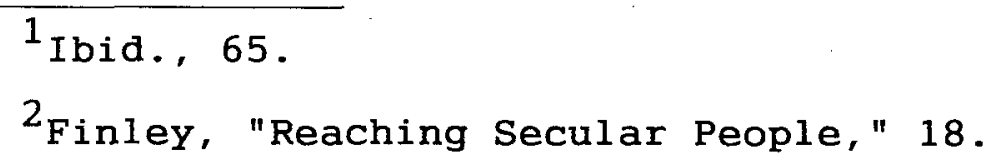


reasons represent at the same time two major groups of needs that modern people have. Home churches have a great potential to meet these needs, and thus, to prevent apostasy.

The challenge of the lack of pastors seems not to be so much a problem of an insufficient number of ministers as a lack of pastoral care. In this case, active lay involvement can provide this missing link in relation to old and new members and to the unchurched as well. Home churches present an organized network for caring for every member in the church.

The challenge of the lack of church buildings cannot be solved in a short period of time. Thus, members gathering at public halls need an additional strategy to help them find their new identity and to be developed as a church. Home churches can become this strategy. Although they will not solve the challenge by themselves, they can greatly influence the health of such congregations in this transitional period.

Another challenge of the Euro-Asia Division is the millions of unreached people. Home churches are a successful device for involving members in reaching their oikos.. They provide support and spiritual growth to the missionary and to his fruits as well. In addition, home churches are a good method for reaching followers of non- 
Christian religions. These people are more communityoriented and need genuine relationships and a supportive group much more than other converts. Usually they are reluctant to enter Christian churches but could be effectively reached through home-based ministries. Furthermore, home churches are an effective means for reaching multitudes in the urban settings through the oneto-one personal labor of laymen.

Miguel Cerna gives, in the article "Win Them and Hold Them," his vision for preventing apostasy and having healthy church members:

I believe there are two basic factors in keeping people and assimilating members: (1) we must organize small groups in which they can be nurtured and develop friendships; (2) we must teach them that as surely as there is a place in heaven for them, there is a place for them to work for God on earth. Small groups provide both a place for nurturing friendships and an evangelistic action unit.

Thus, a house-church approach opens the way "to blend evangelism, assimilation, pastoral care, and leadership development." 2 If implemented in the Euro-Asia Division, it can provide great solutions to the main challenges of the church.

$1_{\text {Miguel Angel Cerna, "Win Them and Hold Them," }}$ Ministry, December 1993, 25.

${ }^{2}$ George, 94 . 


\section{CHAPTER 3 \\ GUIDING PRINCIPLES FOR SETTING UP HOUSE CHURCHES}

This chapter presents the guiding principles for setting up house churches in the Euro-Asia Division. It reviews different approaches to the formation of small groups, the role of the pastor and the congregation, the size of a house church, and the components of home-church meetings.

\section{Formation of Home Churches}

Some questions a pastor starting a small-group ministry in the church must decide on are what kind of groups should they have and on what principles should the groups be formed. This section reviews homogeneous and heterogeneous groups and lists several possibilities of forming small groups in the church, as suggested by Neal McBride in his book How to Lead Small Groups: groups where people choose to join this or that particular group; groups where members are assigned to a certain group; and groups 
that are formed by "random assignment." 1 There are definite advantages and some disadvantages to each of these options. The last section suggests an approach for setting up home churches in the Euro-Asia Division.

\section{Homogeneous vs. Heterogeneous}

Groups can be homogeneous (when one or several of the characteristics of the members are the same or similar) and heterogeneous (when characteristics are different) according to the age, interests, or needs of the people. There are different opinions on this matter as to which method is better for the continuous growth of the small-group members. McBride argues that it is better to form "homogeneous groups in terms of age; other factors can be heterogeneous." 2 He has noticed that there is more common ground between people of the same age (within 5-10 years), which builds stronger relationships in a shorter time. The opposite approach requires more time and skill to meet the diferent kinds of needs people have when there is a lot of diversity .

Groups can also be homogeneous in terms of people's needs or interests. For example, a group of young parents,

$1_{\text {Neal }}$ F. McBride, How to Lead Small Groups (Colorado Springs, CO: NavPress, 1990), 72-73.

${ }^{2}$ Ibid., 73. 
church school teachers, church officers, ${ }^{1}$ single parents, or divorced, aged, or widowed individuals. ${ }^{2}$ And, as Ralph Neighbour suggests, groups can be formed for new believers, for people with certain kinds of problems, for teaching and training believers, and for those committed to service. 3

However, some consider that heterogeneous groups have certain advantages. For example, David W. and Frank P. Johnson express their opinion as follows:

There is a good deal of evidence to show that heterogeneous groups are superior to homogeneous groups in solving problems effectively and in arriving at creative solutions. The usual explanation for the superiority of heterogeneous groups is that they generate a wider variety of ideas on 4 and different possible approaches to, the problem.

This is also true in the church. People learn from each other and serve each other better when they are a diverse group. Then, each small group represents a symbol of Christ's body constituted of many organs with different functions. Although some might object that if people are not united by a common interest they will separate, Keith Miller maintains: "The highest value in the Christian life

$1_{\text {Anderson, } 106 .}$.

${ }^{2}$ steinbron, 204 .

${ }^{3}$ Neighbour, Where Do We Go from Here? A Guidebook for Cel1 Group Churches, 198, 212-214.

${ }^{4}$ David W. Johnson and Frank P. Johnson, Joining Together: Group Theory and Group Skills (Englewood Cliffs, NJ: Prentice Hall, 1975), 273. 
is.. . love (I Cor 13). This is a very important basic difference between Christian joint-adventuring and some (humanistic) psychologically oriented groups." 1

Michael Dibbert and Frank Wichern comment on this matter as follows: "Homogeneous groups are initially easier to get started, but in the long run they do not yield as much growth or satisfaction as heterogeneous groups." 2 Clyde Reid adds that "when a group becomes centered on itself, this may be one indication that its usefulness has ceased." 3 He also continues that "in most circumstances it is an advantage to include in the same group whenever possible a range of persons old and young, male and female, rich and poor." 4 However, it seems more beneficial to have homogeneous groups for children and youth.

\section{Voluntarily Choice of a Group}

There is also another method. For exampple, Yonggi Cho advises to start small. Take several lay leaders, train them, let them form their home meetings, watch them for six

${ }^{1}$ Keith Miller, A Second Touch (Waco, TX: Word Books, 1967), 142 .

2 Michael T. Dibbert and Frank B. Wichern, Growth Groups (Grand Rapids, MI: Zondervan Publishing House, 1985), 47 .

${ }^{3}$ Clyde Reid, Groups Alive--Church Alive (New York: Harper \& Row, Publishers, 1969), 103 .

${ }^{4}$ Ibid., 37. 
to eight months and then, when these groups have begun to bear fruits--involve the whole church. ${ }^{1}$

A question then arises: Who should be included? It seems that the answer is clear: this program will not work if people are assigned to groups. People should be invited to join a group voluntarily. Jeffrey Arnold says: "You should choose your members because of their willingness to grow" ${ }^{2}$ and "the first step is to pull together a small group of disciples who are willing to grow under your leadership. " 3

\section{Assignment to the Group}

Although the freedom to choose to participate in a group by a person can make his or her commitment to the group stronger, some pastors feel that there is a benefit in assigning people to a group. Usually, there are two basic principles ruling the assignment: the needs of the people and the fact that they live within a geographic area. Some churches choose to give the first principle priority, others build their groups around the second one, and still others use both of them. The pastor knows the makeup of the various groups, he knows their potential, he knows which

$$
\begin{aligned}
& { }^{1} \text { Cho, } 111 . \\
& { }^{2} \text { Arnold, } 186 . \\
& { }^{3} \text { Ibid., } 184 .
\end{aligned}
$$


rooms or meeting places are available, when, and so on. But at the same time it seems necessary for the pastor to know the needs of the person before he can make a good assignment to a particular group. For this reason some pastors develop special application forms to discover the needs of those who are willing to join a small group. Once those needs are known, the pastor can then assign the person to a suitable group.

It seems obvious that the division of the city into several districts and then the formation of several small groups in each section has far-reaching mission potential. Michael Skinner in his book House Groups considers that it is essential for the house groups to be composed according to the place of residence of their members. ${ }^{1}$ He sees that local residence is essential "for a group to witness through the mutual ministry of its members, and for a group to discover and try to meet the various existing needs in its neighborhood. "2

C. Reid writes that "the group which becomes mature can be concerned for both the lives of its members and the great social issues in the world around it." 3 It seems that

${ }^{1}$ Michael Skinner, House Groups (London: Epworth Press \& SPCK, 1969), 35 .

$$
\begin{aligned}
& 2 \text { Ibid., } 35 . \\
& 3_{\text {Reid, }} 21 .
\end{aligned}
$$


D. Galloway has the same advantages in view when he reports:

"Making use of the Post Office's Zip Code map, we have

divided the Portland metropolitan area into four

districts." 1 M. Cerna supports this approach:

When we launched the small group ministry, we hired an artisan to make two very large street maps of our territory. . . . On one map we located where each church member lives. . . On the second map we divided the territories for missionary work.

He adds that it is attractive for visitors and newly baptized people to visit a group that is not too far away from their home. 3

So, there are two main advantages of the geographical principle: it is easier for its members to minister to each others' needs and it is easier to focus ministry on a limited geographic territory.

\section{Random Assignment}

Random assignment to the group does not give people freedom of choice in choosing which group to attend nor does it reflect the advantages when people come from the same geographical location or share a common interest. The random assignment method gathers a list of people who are willing to join a group, the number of groups is decided,

${ }^{1}$ Galloway, 126 .

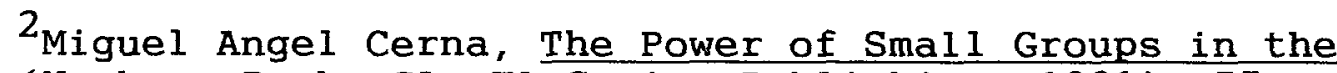
Church (Newbury Park, CA: El Camino Publishing, 1991), 55.

$$
3^{3} \text { Ibid., } 57 .
$$


and "names are randomly drawn and assigned to a group until all the groups are filled." 1 This method can work when all the people are acquainted with each other and if they are willing to join any group. ${ }^{2}$

\section{Suggested Method}

It can be said that it is extremely important that the new converts in the Euro-Asia Division end up in the same group with at least one person who they have already become acquainted with. Thus, on the one hand it is necessary to let people choose their groups by themselves, preserving al ready-formed relationships without forgetting that each group should minister to people having various needs. However, on the other hand, forming groups in geographic areas can help reach multitudes of unreached people, especially in big cities.

Taking all this into consideration, the following method is suggested: start with a limited number of members who are willing to launch a small-group ministry in the church. Let them form groups according to their interests and personal preferences. But keep in mind that the goal is to involve all church members. As the number of small-group members starts to grow, begin to form groups on the basis of

\footnotetext{
$1_{\text {McBride, } 73 .}$

2 Ibid.
} 
geographic area while continuing to grow until all the members of the church are involved. Following this model there might be three phases to the development of small groups.

Phase I: Formation of several small groups on the basis of people's interests and personal preferences. The missionary goal for the members of the groups is to involve their friends, relatives, and the people in their neighborhoods.

Phase II: Transition to two types of groups: those based on the common interests and those formed according to the place of residence. The city (town, village) or territory is divided into districts; necessary preparation is made for the formation of small groups in every district. In this phase peer groups (youth, children) are encouraged with the same mission goals as the other groups.

Phase III: During Phase III geographic groups, interest groups, and peer groups are encouraged with the priority to evangelize every district and minister to those with special needs: singles, youth, etc.

Ron Nicholas in the book Good Things Come in Small Groups gives the example of Elmbrook Church in Wisconsin, which has three thousand members with three types of small groups: peer groups (children, youth, college age); interest groups (singles, women, men, missions, choir); and 
geographic groups (neighborhoods). Every cluster of six neighborhood groups has a regional coordinator, who is under the supervision of a pastoral coordinator. All three types work under and are responsible to the small-group pastor. Regional coordinators meet with the leaders of small groups quarterly. There is also a course every quarter for new neighborhood group leaders. New regional coordinators are trained every year through a twelve-week course and there are also seminars once a year for all leaders to review the main strategy. ${ }^{1}$

Thus, the conclusion can be made that the goal should be the formation of three types of small groups. Most of the groups should be geographical and heterogeneous. However, it is necessary to start with a limited number of groups built around common interests, then preserve those interest groups while developing peer groups and mixed groups in geographic areas of the target territory.

\section{The Role of the Pastor}

Modern pastors are very busy people engaged in a lot of church activities. In some cases this is one reason why they prefer not to be personally involved in the small-group ministry in their congregation. This section gives some

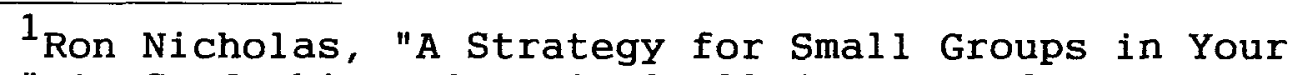
Church," in Good Things Come in Small Groups, ed. Steve Barker (Downers Grove, IL: InterVarsity Press, 1985), 126127. 
views on the role of the pastor in the successful

development of a stable network of home churches.

Cho has expressed (from personal experience) that

without the central involvement of the pastor himself in a small-group ministry such a program would not be successful.

Without the pastor, the system will not hold together. It is a system, and a system must have a control point. The controlling factor in home cell groups is the pastor. . . . I know of many churches that have attempted to set up home cell groups without the central involvement of the pastor. They have all struggled without any real success. If cell groups are to succeed, the pastor must become so convinced of their necessity in the church that he will see them as the key to the life or death of his church. Once he becomes convinced, the program will move.

Skinner supports this view. He says that a pastor plays an important role "in both the creation and sustaining of house groups." 2 It also follows from Cho's observation that in many places where the pastor made an associate minister responsible for organizing small groups while he, himself, remained mainly uninvolved, stagnation occurred and people lost motivation. ${ }^{3}$ He concludes that "the nittygritty can be delegated to an associate, but the leadership must remain with the pastor. He must continue to have an active relationship with the cell leaders." 4

${ }^{1}$ Cho, 109.

${ }^{2}$ Skinner, 70 .

${ }^{3}$ Cho, 108 .

${ }^{4}$ Ibid., 109. 
Thus, it seems crucially important that the pastor himself should become excited about small-group ministry and take leadership in the small-group program in his church. There are several possible ways to do this. Pastors can be given a book or some other material on this topic to read. Pastors can be invited to a seminar on home churches. Pastors can be introduced to other pastors who have already started small-group ministries in their churches.

\section{The Role of the Congregation}

The personal involvement of the pastor in the work of organizing home churches is only one side of the challenge since he needs the support and involvement of his church members. This section focuses on the role of the congregation and on the work of preparing the local church for a small-group ministry.

It is very important for a pastor and a church to clearly understand the goal they want to achieve. Nicholas advises: "Start with a clear understanding of the purpose of your church" and why you need small groups in your church. Then develop an interlinking chain of purpose-strategystructure. ${ }^{1}$ If the church rushes into small groups "without carefully planning how to train and nurture the small group

\footnotetext{
${ }^{1}$ Nicholas, 123 .
} 


\section{5}

leaders on a continuing basis, these groups are heading for trouble." 1

It seems extremely important for a pastor to have a team behind him to successfully achieve a goal. Cerna suggests that the pastor should start with the head elder. He should share with him the plan and they should pray together. If the pastor has personal intercessors they could pray for him through the planning stage and then during the realization of the program. Then the pastor should meet with the board of elders and present the plan at the meeting. 2 If the plan is accepted then the next step is to begin to prepare the congregation.

If the pastor wants to involve the whole church he cannot do it without his people. Since a small-group ministry is suggested for the spiritual growth of the members they themselves should be involved in the process of planning and applying the program to their church. Marlene Wilson explains the extreme importance of people's participation in the planning process in the following words: "People are committed to plans they help make. Yet this frequently is overlooked by both clergy and lay

1 Ibid.

${ }^{2}$ Cerna, The Power of Small Groups in the Church, 230. 
leadership. So, the first principle of good planning is to involve those affected by the plan in the process." 1

Thus, the members should be helped to see the church as the Body of Christ as it is described in the Bible. They should be led to understand the state of their own congregation and become aware of how they can improve it. Melvin J. Steinbron listed several possible options of preparing the people. They are:

1. Preach a series of sermons on the subject. 2. Hold classes to coordinate preaching, teaching, sdudy and discussion.

3. Communicate via church paper and pastoral letters.

4. Share your actions, vision and plans with your people and invite them to be with you in action and spirit.

5. Hold "Lay Witness" renewal weeks or weekends.

6. Have selected books on gifts for ministry, lay involvement in ministry, etc., to sell and/or borrow. 7. Observe members who are already caring for others. Every church has them. Encourage them and draw their attention to their effective ministry. Thęse people are possibilities for your Ministry Group.

Formation of a Ministry group is suggested by Steinbron as the next step. ${ }^{3}$ The pastor "must call forth a group of lay people concerned about the pastoring, and begin to work on it together." 4 The purpose of this group is to pray, to study the Bible, to examine the needs of the

\section{$1_{\text {Marlene Wilson, How to Mobilize Church Volunteers }}$} (Minneapolis, MN: Augsburg Publishing House, 1983), 49.

${ }^{2}$ Steinbron, 60-61.

3 I bid. , 56-62.

${ }^{4}$ Ibid. , 58 . 
congregation, and to see how the suggested approach can help meet them. These people also should state the purpose of the new program, should investigate different possibilities of how to apply the program to their church, and choose the approach that is most relevant to their particular church. It is important to inform the whole congregation of the results and present a tentative schedule.

Then, the training of the home-church leaders can take place. Such questions as who will be the leaders and what kind of structure they will use should have been settled already by the Ministry team. The pastor should teach the selected leaders the main principles of home churches through the actual small-group experience.

Formation of the first home churches by the leaders follows next. As was mentioned above, the first groups are organized according to the common interests, although in some places it is possible that the geographic principle can also be applied from the very beginning.

Cho suggests that after six or eight months all the new group members should be introduced to the congregation during a meeting where members and cell leaders share their testimonies of what God has done and is doing for them. ${ }^{1}$ It might be very helpful to do a similar thing every three to six months on a regular basis. This can encourage the

$$
{ }^{1} \text { Cho, } 115 \text {. }
$$


congregation, show the potential, and help those who doubt to also make a choice to join.

However, there must also be a careful evaluation of everything that has been accomplished, what has failed, and what needs to be improved. It is very helpful to do this after the first six or eight months from launching the program and then continue to evaluate regularly.

Thus, the congregation has a crucial role to play in the successful development of a small-group ministry. It should be prepared by the pastor and its members should be involved from the beginning in the planning, development, and evaluation of the entire process.

\section{The Size of a Home Church}

This section presents views of different authors on the need to limit the number of people in a small group or house church to a certain figure in order to be effective.

It seems obvious that in the beginning of the history of the Christian church the number of people in a home church was limited by the size of the house. ${ }^{1}$ At the present time the SDA church in the Euro-Asia Division has church buildings and rented public halls from which to run

$1_{\text {Adolf Harnack, The Mission and Expansion of }}$ Christianity in the First Three Centuries, 2 vols. (London: Williams and Norgate, 1908), 2:85. See also Hans-Josef Klauck, "The House Church as Way of Life," Theology Digest 30 (1982): 154 . 
its Sabbath services. Nevertheless, the practice has shown that the church also needs something in addition to these Sabbath services to help the members improve their spiritual life and become dynamic Christian witnesses in the community. This is why the church should be interested not simply in how many people can fit into a house when using the home-church approach, but also in limiting the number to a size that can provide quality relationships and produce the desired results.

It is interesting to note that at the present time different authors come to similar conclusions regarding the optimal number of people in a small group or house church. Anderson states that the group must number from three to fifteen people. His opinion is that it should not be more than that in order to function effectively. 1 Reid sees the ideal size of such a group as eight to twelve people. ${ }^{2}$ Desher points out that "the small personal group, made up of not more than ten to twelve individuals, is able to meet the yearning to belong to a fellowship in which personal relationships are satisfying and significant." 3 C. Davis considers that the group size should be somewhere between six and twelve: "With fewer than six, something vital is

\footnotetext{
${ }^{1}$ Anderson, 12 .

${ }^{2}$ Reid, 36 .

3 Deshler, 14 .
} 
lost. With more than twelve, spontaneity and participation are lost." 1 Stanley Brown and Robert Deits continue:

"Successful groups vary greatly in size; however, the ideal range is eight to twelve persons--with a minimum of five and a maximum of fifteen." 2 Monte Sahlin says: "The 'small group' is anywhere from three to 12 people. It is most effective at 8 to 10 members." 3

In addition, it can be added that Jesus chose exactly twelve to be with Him as a small group. Although it seems that He did it with the number of twelve tribes of Israel in mind, it probably can also indicate that Jesus knew the right size of a group for establishing deeper relationships. Discussing this issue of Jesus' method, R. Coleman comments: "The necessity is apparent not only to select a few laymen, but to keep the group small enough to be able to work effectively with them." 4 Cerna adds: "We believe the groups should number from eight to twelve church members. The Lord

\section{${ }^{1}$ Davis, 166 .}

${ }^{2}$ Stanley C. Brown and Robert $H$. Deits, Folly or Power? Encounter Groups in the Church (New York: Hawthorn Books, W. Clement Stone, Publisher, 1975), 72.

${ }^{3}$ Monte Sahlin, Sharing Our Faith with Friends without Losing Either (Washington, DC: Review and Herald Publishing Association, 1990), 138.

${ }^{4}$ Robert E. Coleman, The Master Plan of Evangelism (Old Tappan, NJ: Fleming H. Revell Company, 1964), 24. 
had only twelve members in His group and we don't try to improve on His method." 1

So, we can conclude that many authors see the best size for a small group as being somewhere between three and twelve. It seems that there should be three people for sure to start a group: a leader, his assistant, and a host.

\section{Components of Home-Church Meetings}

This section reviews necessary components of housechurch meeting on the basis of Acts 2:42-47, where four ingredients in home meetings in Jerusalem are described: nurture through the apostles' teaching, worship, community, and mission. 2

Dossman writes in his book From House to House about "three basic relational concerns for the church:" 3 the relationships between (1) the believer and God; (2) the believer and other believers; (3) the believer and unbeliever. It looks like these very components of homechurch meetings can help the modern church reach the goals that are now standing before it. The first two components help strengthen each member's relationships with God, the

\footnotetext{
${ }^{1}$ Cerna, The Power of Small Groups in the Church, 56.

${ }^{2}$ Ron Nicholas, "The Basics of Small Group Life," in Small Group Leaders' Handbook, ed. Steve Barker (Downers Grove, IL: Intervarsity Press, 1982), 34-35.

${ }^{3}$ Dossman, 41 .
} 
third one helps build relationships between members, and the fourth one helps each member reach people outside the church. Norman E. Wegmeyer says that "the chief business of the church is to help all men grow in relationship with Jesus Christ and with each other."1 Leroy Eims supports this in the following words, "But people will not witness unless they first spend time with Jesus Christ." 2

\section{Nurture}

Thus, it follows that one of the main parts of the home-church service must be the study of the Scriptures. One may ask in this connection, what kind of resources should a leader and the members use? Although there are many helpful tools, some authors consider that the best strategy would be to teach leaders and members to use the inductive method of searching the Scriptures. This method includes three steps: observation (when the reader gathers the information from the text: What does the passage say?), interpretation (when the reader tries to discover what it meant for the people to whom it was written: What does the passage mean?), and application (when the reader learns some

\section{$1_{\text {Norman E. Wegmeyer, The Art of Christian }}$}

Relationships (Minneapolis, MN: Augsburg Publishing House, 1967), 7 .

2 Leroy Eims, The Lost Art of Disciple Making (Grand Rapids: Zondervan Publishing House, 1978), 54. 


\section{3}

lessons from the studied passage and sees how they can be applied to his life: What does the passage mean to me?). 1

Arnold explains why it is the most effective tool: "Inductive study is successful because it provides the tools for normal people to read, interpret and apply the word of God. When used properly, inductive study makes the Bible come alive." 2

It seems that this method can be very helpful in Russia, where people do not have very many sources and tools available in the Russian language. This method is not only for educated members or pastors but for new converts as well. It helps people to work with the text itself and learn how to make it speak to them in their modern setting today .

There are different approaches to Bible studies: studying characters of the Bible, themes of the Bible, books of the Bible, and others. 3 It seems that it would be a great help to new converts in the Euro-Asia Division if they chose one of the Gospels to begin with. This is better than the first two approaches because studying the characters and

${ }^{1}$ Jimmy Long, "Inductive Bible Study," in Small Group Leaders' Handbook, ed. Steve Barker (Downers Grove, IL: InterVarsity Press, 1982), 107-113.

2 Arnold, 43.

${ }^{3}$ Ibid. , 123-125. 
themes of the Bible is more complex and often requires additional tools.

Some people think that it is helpful for a group with new converts to start with a series developed from the ethical issues in the epistles of Paul, Peter, and James. This is certainly good for new members. However, the regular small groups are not the best places for this type of study. It seems that it is better to organize Sabbath School classes for these new converts or to follow the system of Neighbour, who gathers them into separate small groups of "baby Christians." 1 The main objection to studying these themes in the small groups is that there will be newcomers regularly joining the groups. It is unthinkable for a group to return over and over to the starting point every time a new believer joins or to repeat the same cycle to be sure that everyone who joined at a later date understands all the material covered.

The study of a Gospel solves this kind of problem in a better way. It does not basically matter if the person starts in the beginning with the group or joins it later. People will meet Jesus as a person, and it is equally important and relevant to meet Him in any chapter and in any phase of His life. Those who are very interested can read

${ }^{1}$ Ralph W. Neighbour, Jr., The Shepherd's Guidebook (Houston, TX: Touch Publications, 1992), 7. 
at home the chapters that have already been studied by the group. It seems that this approach provides people with a system that allows everyone to know what they will study next week so they can prepare for the lesson at home. Thus, Bible students will not only gather information about Jesus in a Gospel, but with the help of the inductive method and also E. G. White's Desire of Ages (which is available in the Russian language) will come to know Christ Himself. This seems basic and extremely important for every church member and especially for a newly converted person. So, this component of home-church meetings provides the oportunity to investigate the Bible, to apply its message to modern life, to know Christ in a personal way, and to grow spiritually.

Every believer in Jesus Christ deserves the opportunity of personal nurture and development. Every new believer is expected to achieve his or her full potential for God. And most of them would if they had the opportunity, if someone would get the food within reach, if someone would give them the help they need, if someone would give them the training they should have. 1

Worship

Worship is another component of a home-church meeting. It seems impossible to be called a church and not to pray, sing, or praise God. Dossman expresses the significance of prayer time in home churches as follows:

I have never been more excited about prayer in small groups than I am right now. . . It is my opinion that

\footnotetext{
$1_{\text {Eims, }} 11-12$.
} 
the prayer time should not be rushed in the small group context because this is a genuine pathway into the hearts of those who you are trying to reach for Christ. - . Prayer is a very effective tool in refocusing the people on the importance of understanding and following the will of God.

Worship in the home church is also time for praise and adoration. The unifying and inspiring function of singing cannot be overestimated. Alongside with other forms of prayer, conversational prayer can teach every member of a group to express personal praises to God as well as personal needs and the needs of others. 2

It seems that this component of home-church meetings can be especially beneficial for new converts in the EuroAsia Division. As was shown in chapter 2, the development of meaningful relationships with God is one of their major needs. A home church can become a place where new members gradually learn to pray personally and aloud. Additionally, church hymns can be learned, and testimonies of others can be remembered as an encouragement. While the first component (inductive Bible study) provides believers with the opportunity to discover God speaking to their hearts, this second component gives them time for a personal response to the Lord, and thus, leads to the development of two-way communication.

${ }^{1}$ Dossman, 56-57.

2 How to Lead Small Group Bible Studies (Colorado Springs, CO: NavPress, 1983), 54-55. 


\section{Community}

Another main component of a home-church meeting is community or fellowship. As was presented in chapter 2, the second major reason for apostasy of new converts in the Euro-Asia Division is loneliness in the church. It should be noted that this need for meaningful friendship and fellowship in the church is a common need of new believers, and it does not matter whether they are from the Euro-Asia or North American Division. As Oosterwal reports on his findings in some churches in the Lake Union Conference:

New members, without an Adventist background, often do not feel at home in the church. They feel as outsiders. They don't share in the "Adventist group experience": they don't speak the "Adventisf language," nor do they understand Adventist behavior.

He continues that members "reared in the Adventist community" often do not understand this and "fail to include the new members in their social life, their groups, their community." 2 As a result, many new members apostatize. He reports that in his study of twenty-eight "rapidly growing churches" each of them "was characterized by a social life and a group fellowship that included especially the new members. " 3

${ }^{1}$ Gottfried Oosterwal, "Patterns of SDA Church Growth in North America," Research Report No. 1, Department of World Mission, Andrews University, 1974, 60.

2 Ibid., 61.

${ }^{3}$ Ibid. 
Thus, this component of a home-church meeting is a very important one. It helps build meaningful relationships between its members. Ice-breaking exercises, meals together, and other social activities lay down a good foundation for lasting relations. It should also be noted that such meetings must become places where members share not only their views, knowledge, feelings, and needs but also where ministry takes place as each member uses his or her spiritual gifts. Reid states that "it is probably a fact that groups fail when they do not meet the needs of their members." 1 This component of home-church meetings binds its members together and prepares them for successful ministry to other people.

\section{Mission}

Mission was another component in the early church. Many authors feel there is a direct relationship between searching the Scriptures, relationships with God, and saving others. Skinner expresses it in the following way: "A witnessing church means a Bible reading church." 2 Deshler communicates this idea as follows:

There are too many for whom religion is a form, but not a power. Until God becomes real, until the Bible becomes His voice, and until prayer becomes communication with Him, all these nominal Christians

\footnotetext{
$1_{\text {Reid, }} 104$.

2 skinner, 93 .
} 
constitute an inert load retarding the church from fulfilling its commission.

Eric Wright also underlines the importance of prayer and worship in this connection: "Evangelism and missions, in a biblical sense, are not ends in themselves but action taken as a result of priorities given to worship and prayer." 2

We might ask, "What is meant by mission?"

The concept of mission includes such things as evangelism and social action. It also includes what is often called world missions, but it is broader than that. The concept covers everything from telling a neighbor about the Lord, to bringing a meal to the sick, to sending a couple of members of the group to Africa to learn how the church here can assist the church there.

As was shown in chapter 2, a home church can become an effective means for reaching oikos of its members, for reaching urban multitudes and people from other nonChristian religions. Its potential for success is explained mainly by two reasons: a limited number of people are focused on the specific task, and people committed to the task are also committed to each other. So, a home church can prepare its members for mission, can support them during mission outreach, and can help them to develop an even

\section{${ }^{1}$ Deshler, 41 .}

${ }^{2}$ Eric Wright, Tell the World: Apostolic Patterns for Evangelism and Missions (Welwyn, Hertfordshire: Evangelical Press, 1981), 104 .

${ }^{3}$ Ron Nicholas, "The Four Ingregients of Good Group Life," in Good Things Come in Small Groups, 26. 
broader mission perspective. Additionally, it "can be a good place of beginning for the seeker who hesitates as yet, to attend a church, "1 especially if he or she is from a nonChristian religion.

However, there are two approaches to this component of a small group. The first one incorporates "mission" in a home-church meeting indirectly, primarily through worship or sharing time when prayer requests and testimonies of answered prayers (often connected with the positive response of a "target" person) are expressed. ${ }^{2}$ The other approach includes a specific period of time for discussing, planning, and praying for mission of this small group. ${ }^{3}$

It seems that the second approach can be more effective in keeping the focus of home-church members on mission. Taking into consideration the great challenge of the unreached peoples in the Euro-Asia Division, it is suggested that a home church include directly all four ingredients in its meeting. Some authors think that although there are a variety of small groups, all of them need these four main ingredients although the proportion of

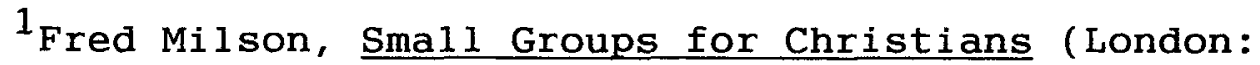
Methodist Church Division of Education and Youth, 1982), 22. ${ }^{2}$ Gall loway, 151 . ${ }^{3}$ Cerna, The Power of Small Groups in the Church, 7077 . 
time can vary. ${ }^{1}$ Some suggest that home-church meetings should last from one and a half to two hours, with the time divided in the following way: forty minutes to nurture, twenty minutes to community, fifteen minutes to worship, and fifteen minutes to mission. ${ }^{2}$ It has been noticed that "if a group never engages in mission, it loses its common purpose and starts to become disunified. If a small group is not serving others, it becomes self-serving, lazy and unhealthy." 3 "There is only one way that the home cell group system will be successful in a church, if that system is to be used as a tool of evangelism." 4

\section{Summary}

In conclusion, it seems very important to have a goal to organize a home church in every district of a city. From this perspective, most of the groups should be geographical and heterogeneous. However, it is necessary to start with a limited number of groups built around common interests, then preserve those interest groups while developing peer groups 27.

${ }^{1}$ Nicholas, "The Four Ingregients of Good Group Life,"

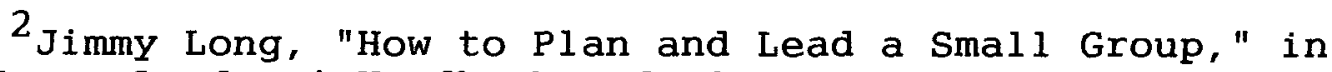
Small Group Leaders' Handbook, ed. Steve Barker (Downers Grove, IL: InterVarsity Press, 1982), 124.

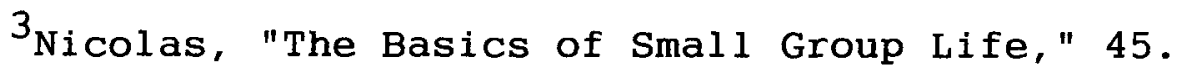

${ }^{4} \mathrm{Cho}$, 107 . 
and mixed groups in geographic areas of the target territory.

The pastor has a crucial role to play in the development of small groups in his church. He should be personly involved in this work and include in his responsibilities the task to organize a group of people who will help him to develop the strategy, to prepare the leaders, to start the program, to evaluate it and, if it is needed, to improve it. Without the central involvement of the pastor in a small group ministry this program will not be succesful.

Furthermore, the pastor cannot achieve much in this ministry unless most of the members are involved. Thus, the congregation should be prepared by the pastor by being involved from the very beginning in the planning, development, and evaluation of the entire process as much as possible.

The best size for small groups is from three to twelve people. The three key persons necessary to start a group are a leader, an assistant, and a host.

The home-church service should include four main components: nurture, worship, fellowship, and mission. All four are important and should be included in any format used for a home-church meeting. These four aspects provide opportunity for the church to accomplish three major tasks: 
to help church members build meaningful relationships with God, to establish strong relationships with each other, and to find the ways for building deep relationships with unbelievers. 
CHAPTER 4

\section{THE SELECTION AND TRAINING OF HOME-CHURCH LEADERS}

The selection and training of home-church leaders is a matter of vital importance. This chapter focuses on the function and role of the trainer, proposes a training schedule, and presents principles for selection of homechurch leaders.

\section{The Function and Role of the Trainer}

This section discusses the question of who should train home-church leaders and suggests an approach to a trainer's leadership and teaching.

Who Should Be the Trainer?

One of the most important questions in a small-group ministry is a question of responsibility. Who in a congregation will be responsible for the development of house churches and for the training of home-church leaders? As the practice shows, usually it is the same person who carries both tasks. 
It was shown in chapter 3 that the pastor plays a crucial role in the success of a small-group ministry. Thus, it can be assumed that the pastor is the only suitable candidate for the development of small groups and the training of group leaders. However, there are several different approaches to this matter.

Karen Hurston, who worked several years as a staff member in the Yoido Full Gospel Church pastored by Paul Yonggi Cho, made a thorough analysis of existing systems of small groups in churches throughout the United States. On the basis of this study and her experience, she concluded that there are three major support systems for small-group ministry. She called them the appendage system, the incorporated system, and the integrated system. ${ }^{1}$

The appendage system is started by a lay member who chooses leaders for small groups "from among church friends and acquaintances, giving sporadic leadership training." 2 Usually this person becomes the coordinator. "The role of senior pastor is to give permission to a layperson to start groups and to make announcements about the groups during worship services or place occasional invitations in the bulletin." 3 Typically, this system involves "less than 20

${ }^{1}$ Hurston, $199-205$.

${ }^{2}$ Ibid., 200.

3 Ibid. 
percent of the congregation" since "the vision for the groups does not come from the church's primary leadership." 1 These groups largely concentrate on Bible study and fellowship and not on evangelistic outreach. Thus, in the appendage system, small groups "are lay-led and most often lay-initiated": they exist "with little or no staff support or recognition." 2 This system "quickly dissolves" when the resignation or departure of the key layperson occurs. 3

The second system, called incorporated, is more common (found in about 80-90 percent of the congregations that have small groups). 4 In this system, the vision comes through the pastor. He promotes it to the staff and congregation but delegates supervision of small-group ministry to a committee or a staff person, usually to an associate pastor who becomes a coordinator. 5 volunteers, often active layleaders, go through the session of initial training and become group leaders. Then the coordinator recruits additional ones developed through the groups and provides ongoing training. The coordinator oversees either

\section{$1_{\text {Ibid. }}$}

2 Floyd L. Schwanz, Growing Small Groups (Kansas City, MO: Beacon Hill Press of Kansas City, 1995), 82.

${ }^{3}$ Hurston, 200 .

${ }^{4}$ Ibid.

${ }^{5}$ Ibid., 200-201. 
all small-group leaders or just section leaders who, in turn, oversee the group leaders (if the program is more developed). He also reports regularly to the senior pastor. ${ }^{1}$

As Hurston states, typically about 20 to 50 percent of the congregation respond to this system since the members see it "as another program incorporated into the many activities of the church." ${ }^{2}$ She says that "it is one of the best ways to develop a network of pastoral care in a congregation" and provides "assimilation for new members." 3 However, the weaknesses of the incorporated system are the partial involvement of the pastor, partial involvement of the congregation, and lack of focus on evangelistic activities.

Third, the integrated system is represented by less than 1 percent of congregations with small-group programs. 4 Nevertheless, these few churches "bring the greatest congregational response--often 80 to 90 percent of these congregations become involved" in small groups. ${ }^{5}$ In this program, the senior pastor is a key person. Members

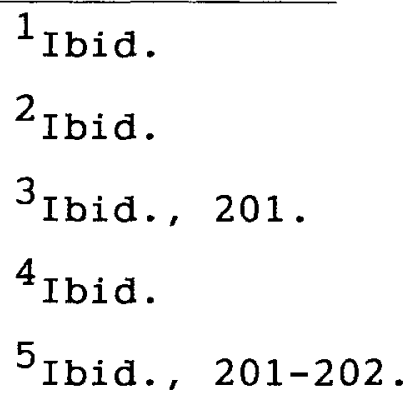


perceive small groups as an inherent part of their church life, and the congregation is constantly growing. ${ }^{1}$ There can be two kinds of management in this system: the "adapted model, allowing some traditional patterns of programs to coexist" and the "refined model, with staff's main focus on personal ministry and leadership development." 2

To summarize, there are several distinctive characteristics of this system. The first one is the pastor's central role in the implementation and development of the small-group ministry. He is an "initiator, vision bearer, and ministry model" ${ }^{3}$ as well as the trainer. The second characteristic is "a multiple pastoral and laystaff," which concentrates on leadership development and personal ministry to group leaders. ${ }^{4}$ The third distinctive trait of the integrated system is that the majority of the congregation is involved. 5 Another characteristic is evangelistic outreach. As Hurston states, it is the "only system that results in widespread evangelism." 6 The fifth

${ }^{1}$ Ibid.

2 Ibid., 203.

${ }^{3}$ Ibid.

${ }^{4}$ Ibid., 202.

${ }^{5}$ Ibid.

6Ibid., 202-203. 
peculiarity of the system is that more time is required for its development. 1

Hurston names several churches, listed below, that have the integrated support system for small-group ministry: Victory Assembly in Metairie, Louisiana--pastored by Frank Bailey; New Hope Community in Portland, Oregon--pastored by Dale Galloway; Cathedral of Praise in Manila, Philippines-pastored by Dr. David Sumrall; and Yoido Full Gospel Church in Seol, Korea--pastored by David Yonggi Cho. ${ }^{2}$

Thus, these three systems give three different answers to the question of responsibility. The person who is responsible for the development of the small-group ministry and for the training of group leaders can be a laymember, an appointed staff person, and the pastor of the congregation. There is an additional option for the training of group leaders--it can also be provided by an invited expert who comes just for the training sessions. Thus, who the trainer will be largely depends on the person who first got a vision of the small-group approach and on the reaction of the pastor towards this vision.

Deliberately or not, his or her actions will eventually lead small-group ministry to one of the described systems.

\footnotetext{
${ }^{1}$ Ibid.

${ }^{2}$ Ibid., 204-205.
} 
In view of the major challenges of the Euro-Asia Division presented in chapter 1 and the three systems described above, it seems that there is only one system that can be the most beneficial to this Division. The integrated support system with the central involvement of the pastor can successfully meet the nurture of believers and reach the unreached through home churches. In addition, it mobilizes up to 90 percent of the membership to active growth and mission. If the two other systems were chosen, people would perceive a small-group ministry as "just another department" or "another choice among many." 1 The response would be partial and about 50 percent of the membership of the EuroAsia Division would still be lonely and lacking nurture in a best-case scenario.

However, the pastor can consider the training of group leaders by an invited expert as beneficial. This option can seem very effective at first sight. Seminars by invited experts usually are very informative. However, if the training of leaders always depends on a guest speaker, the smal1-group ministry does not take roots at home. Furthermore, a pastor cannot consider himself central in this ministry if he does not directly influence the very core of it, namely, the future leaders. In addition, this option undermines a very important point: the

$$
1 \text { Ibid. }
$$


distinctiveness of every congregation. Nobody from outside can know the congregation better than the pastor does. Thus, he is in a better position to adjust the program to the very peculiarities of his church and to shape homechurch leaders according to his vision. It surely requires additional effort from the pastor to gain the information, to develop the vision, and to get training for himself, but it is definitely worth it. If the pastor wants small groups to become a priority for his people, he must show that it is a priority for him. ${ }^{1}$

Schwanz states that the pastor's role in a smallgroup ministry is so important that once he has decided to implement this ministry he "needs to stay in a central place of leadership." ${ }^{2}$ He "nurtures leaders one-to-one and in small groups" 3 and "provides both the training opportunities and the material." 4 Kurt Johnson strongly advocates the necessity of the pastor's direct involvement in the smallgroup ministry in the following words:

The pastor's leadership and support in the small group organizational and functioning process is the difference between success and mediocrity. While it is true that small group leadership and participation is a

\footnotetext{
${ }^{1}$ Schwanz, 85, 87-88.

2 Ibid., 85.

3 Ibid. , 193 .

${ }^{4}$ Ibid. , 194 .
} 
lay member's responsibility, pastor involvement is vitally necessary.

He also lists a need for the pastor to "provide continual training in small groups and evangelism techniques for his lay leaders" ${ }^{2}$ among his other requirements.

Thus, the integrated system, with the pastor as a key person in the group development and leaders' training, is suggested for the Euro-Asia Division. It seems to be the only system that can nurture new converts of this Division, who comprise about 78 percent of the church membership, and also reach the unreached. The choice of this system will inevitably lead to the restructuring of a congregation. Neighbour shares his deep conviction about the necessity of radical restructuring of the church for small-group ministry if success is desired:

A church cannot effectively mix traditional patterns of church life with cell group patterns. There must be a deliberate transition. After devoting nearly a quarter of a century to the attempt to help "renew the churches," I am a total skeptic that it can be done. The only hope for old wineskins is to pour out the wine they çontain into new ones and throw the leaky things away! ${ }^{3}$

However, if an application of the integrated system is impossible for any reason, either of the other two

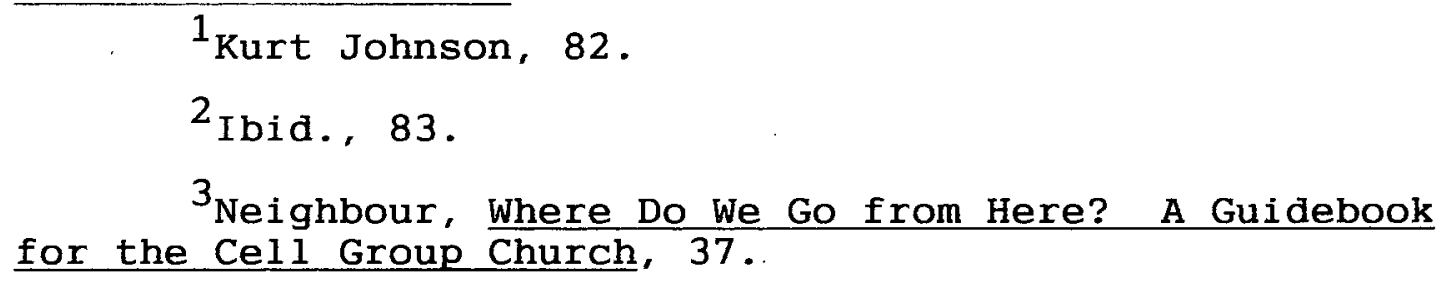


approaches should be encouraged. Although fewer of a congregation will be involved, it is better to help at least some members than to reject the small-group ministry totally.

The Approach to Leadership ${ }^{1}$

The pastor as the trainer models group leadership by his own example. Thus, the concept of leadership that is translated to them by his actions is very important.

It is commonly accepted that there are four major types of leadership: autocratic, authoritative, democratic, and laissez-faire. ${ }^{2}$ A democratic style of a leadership is often connected with the role of facilitator-enabler. And small-group leaders are usually encouraged to become facilitators. ${ }^{3}$ At the same time, it is advisable to start with an authoritative style and gradually move to a democratic one alongside the growing maturity of small-group members. 4

${ }^{1}$ Leadership development is an area of weakness and a sensitive issue in the Euro-Asia Division. In view of this problem and the challenge of an inadequate number of pastors, the approach to leadership in the training process is discussed more thoroughly.

${ }^{2}$ For definition and characteristics of the four styles of leadership, see Hestenes, 65; Schilt, 59.

${ }^{3} \operatorname{Schi1t}, 57$.

${ }^{4}$ Ibid. 
However, it seems that there is some tension here. Em Griffin, for example, states that there is "no one style that works best in all situations." 1 Different situations can require different styles, and "flexibility in leadership style is a necessity." 2 Additionally, it depends on people-what style of leadership they are more comfortable with, 3 how mature they are, and what stage of the group life they are going through. ${ }^{4}$ Griffin concludes that the actual task for a group leader is to define and satisfy the needs of the people. 5 Thus, "the real leader is the person who has the will and the skill to meet the needs of the group." 6 And it follows that different groups might need different approaches.

Furthermore, I have noted through personal observation that often group leaders are confused with the challenge to become or remain a facilitator and the demands of the situation in the group. Sometimes leaders choose to remain passive rather than to take any initiative when the

${ }^{1}$ Em Griffin, Getting Together: A Guide for Good

Groups (Downers Grove, IL: Intervarsity Press, 1982), 56.

2 James E. Means, Leadership in Christian Ministry

(Grand Rapids, MI: Baker Book House, 1989), 74 .

${ }^{3}$ Griffin, 56 .

${ }^{4}$ Ibid., 30-31.

5 Ibid., 56 .

6 Ibid. 
group members are not ready to handle a certain problem by themselves. At the same time, these leaders perceive themselves as enablers, stimulating people to take leadership in decision making, and not as leaders with the laissez-faire style. The democratic-type leader takes comfort from the following statement: "The leader's withdrawal will not mean the group will fall apart." 1 The situation becomes even more dangerous when the group leaders allow one or several group members with little Christian experience to push the group in a wrong direction. However, the leaders justify their withdrawal by the explanation that they did not want to lose their image as a democratic leader.

The following addresses a similar situation:

Groups need structure, and it is the responsibility of the leader to provide it. Facilitators do not have to become authoritarian leaders in order to provide it.

As a group gets underway, the members will initially be looking to the facilitator for guidance and direction. If the leader fails to provide direction, group members will probably become frustrated and waste time trying to decide who should be in charge.

However, it seems like the author of these words limits the provision of structure to setting the expectations, organizational questions, and goals of the group. He advises doing this through explaining, taking

\footnotetext{
${ }^{1}$ Schilt, 59.

${ }^{2}$ Dibbert and Wichern, 58-59.
} 
"the initiative in the early stages," and modeling the right attitude by personal example. ${ }^{1}$ James Means goes further and addresses the false perception that spiritual leaders should not be aggressive:

Leaders must not become dictators or mere power wielders; yet, there are times and situations when leaders must become quite aggressive in their ethical attempts to influence people and decisions. The best biblical leaders were sometimes very aggressive in leadership. It is crucial that spiritual leaders understand when such behavior is approgriate and compatible with scriptural guidelines.

This shows that a concept of effective leadership is broader than just one style of leadership and the group leaders must be aware of this. In the context of these problems, it is interesting to look at another view of what it means to be an effective leader. Lovett $H$. Weems convincingly argues that there are three common confusions concerning leadership: confusion between leadership and authority, confusion between leadership and style, and confusion of leadership with enabling and empowering. 3

The first confusion shows a misunderstanding of the fact that "authority can be given, leadership must be earned." 4 In other words, a position automatically provides

${ }^{1}$ Ibid.

$2_{\text {Means, }} 74$.

${ }^{3}$ Lovett H. Weems, Jr., Church Leadership (Nashville, TN: Abingdon Press, 1993), 29-34.

${ }^{4}$ Ibid., 30 . 
a person with a certain degree of authority and opportunity to lead. However, "the final test for all leaders is whether someone is following." 1

The second confusion demonstrates that people often link leadership with a certain negative style of leadership. Weems states that none of the leadership styles "is synonymous with leadership any more than a particular style of teaching is synonymous with education." 2 He shows that there is a false assumption in such leadership images as a continuum with the authoritarian leader on one end and the laissez-faire on the other and a grid with the task-oriented and people-oriented leaders. This false assumption concludes that "the more the pastor moves toward an authoritarian model, the stronger the pastor is and the weaker laypeople are; and the more the pastor moves toward a laissez-faire model, the weaker the pastor is and the stronger the laypeople are." 3 Weems says that this assumption was destroyed for him by research among several churches including one congregation with a traditionally strong lay ministry. The people of this particular church repeatedly pointed to the pastor as a key leader. After that, Weems began to look for an interactive approach to
${ }^{1}$ Ibid.
2 Ibid.
$3^{3}$ Ibid., 31 . 
leadership where "pastor and people are strong together." I He states that this approach "can be used by persons with many different personal styles of leadership in a helpful and upbuilding way." 2

The third confusion is that many people associate empowering and enabling with an effective leadership while not recognizing that these are not enough for success. Weems points out that these characteristics "will keep you from abusing a group," but at the same time "will not necessarily mean that you will provide leadership for the group." 3 He stresses the fact that very often such an approach leads to "the country club model of leadership," where a leader "gets some people together, asks them what they want, writes it on newsprint, and then tries to make sure that it happens." 4 Empowering, as he sees it, is a two-way street. "The real question is not so much whether the leader will empower the people, but whether the people will empower the leader to be effective." 5

Kennon Callahan supports this idea by stating that one of the key characteristics "of effective, successful

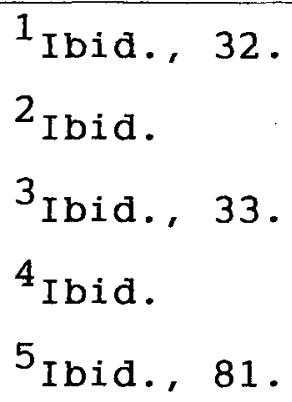


congregations is strong leadership." 1 To analyze the degree of strong leadership resources in the congregation, he looks at "the extent to which there are leaders, not enablers, in the central positions of leadership." 2 He notes that while "in the churched culture of the 1950s, it was possible for the church to focus on developing enablers," however, "in the unchurched culture of the 1980s it is decisively important that the church focus on developing leaders." 3 From his point of view, "local congregations need more leaders and fewer enablers." 4

This seems even more true for the situation in the Euro-Asia Division where about 78 percent of the membership are represented by people who came recently from "the unchurched culture." Unfortunately, they often look like sheep without a real shepherd in the small groups with undeveloped leaders. The concept that anyone from the group can immediately be a leader has caused one of the most destructive problems in the home churches of this Division. Reid argues in regard to shared leadership that while it may be very effective in many situations, "the

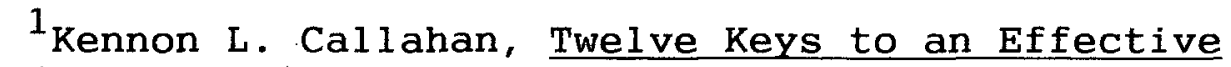
Church (San Francisco, CA: Harper and Row, Publishers, 1983), 41 .

2 Ibid.

$3_{\text {Ibid. }}$

${ }^{4}$ Ibid. , 42. 
flexibility concept reveals that firm leadership centered in one person is necessary at times." 1 He compares the relationships of the leader and group with that of a parent and child. While a parent needs to communicate love and acceptance, he or she also has the responsibility to set limits and watch for them. There will be some situations where the leader of small group "needs to say, 'No, we don't deal with that.' Or, 'I'm sorry, but that's out of bounds. ' "2

Weems rightly states that leading people to an appropriate and shared vision is "one responsibility that cannot be delegated." 3 From his point of view, "leadership is the development and articulation of a shared vision, motivation of those key people without whom that vision cannot become a reality, and gaining the cooperation of most of the people involved." 4 James Kouzes and Barry Posner also show that enabling others is just one of the five practices of successful leaders. 5 The other four are

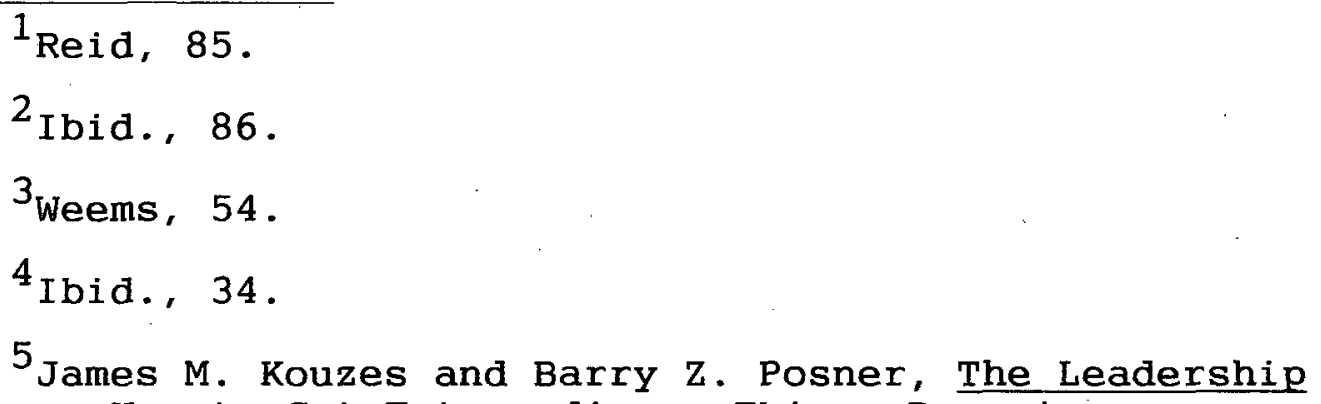
Challenge: How to Get Extraordinary Things Done in Organizations (San Francisco, CA: Jossey-Bass, Publishers, $1987), 8$. 
challenging the process, inspiring a shared vision, modeling the way, and encouraging the heart. ${ }^{1}$ Galloway stresses the necessity of strong leadership in the church. ${ }^{2}$ He says:

All church growth experts agree that the primary catalyst for growth in a local church is having a strong pastor who will be the leader. The pastor must be a man of insight and vision, who is not afraid to make decisions and who, in his walk with God, senses and knows the right time to act."

It should be noted that many point to the biblical concept of the servant-leader. However, as Doug Whallon concludes, this "model of leadership is build on twin concepts:(1) a servant serves by leading, and (2) a leader leads by serving." 4 Especially in the early stages, the group needs the application of the first principle. With the increase of group identity, there are more demands for the second. 5 The group leader should lead the group members "to grow away from dependence upon him, " 6 but this does not mean his retirement as a leader. He should not cease to be a vision bearer, leading people to the higher task. The

${ }^{1}$ Ibid.

${ }^{2}$ Galloway, 87 .

3 I bid., 88 .

${ }^{4}$ Doug whallon, "Leadership--the Critical Factor," in Good Things Come in Small Groups, ed. Steve Barker (Downers Grove, IL: InterVarsity Press, 1985), 42.

${ }^{5}$ Ibid., 42-44.

6 Ibid. 


\section{2}

important thing is that church leaders should be focused on both task and people. ${ }^{1}$ The image of the shepherd includes, among other characteristics, responsibility for nurture and guidance of the sheep. 2 Although Jesus used different approaches, He always "remained both people-centered and task-oriented." 3

Thus, it is suggested that the pastor as the trainer should convey a solid concept of leadership to home-church leaders. He should be not only an enabler but a strong spiritual leader--a leader who is not afraid to take risks and make decisions, who provides a sense of security to his followers, who takes responsibility for the actions taken in a group, and who is focused on both people and task. Such a leader would provide opportunities for people to discover and apply their spiritual gifts but would always remain responsible for the directions in which the people move.

\section{The Training Method}

The pastor as the trainer will also model for the group leaders through the method of teaching. Thus, the kind of method chosen for the training of group leaders is
$1_{\text {Means, }} 13$.
2 Ibid., 52 .
3 Whallon, 43. 


\section{3}

very important. There are several possible approaches to this matter.

The first method is "to plant the kind of group you want to be multiplied," 1 inviting potential leaders there but not asking them to make a commitment to be future leaders. Let them experience for themselves what a smallgroup ministry is like. Then, gather those who have a desire to be the future leaders and give them additional training in a weekend. Schwantz promotes this approach very strongly since he saw the good results of such a method of training. This is his way of starting a small-group ministry in a congregation of any size--300 or 1,000. He says, "I would start three pilot groups: an early-morning men's group that I would lead, a neighborhood ladies' group my wife would lead, and one mixed group we would lead together." 2 This method can be called the group experience plus a seminar.

The second approach is to gather volunteers for a small-group ministry or people chosen by the church staff for a training session and teach them in the classroom with a lecture format. Schwanz says to "avoid beginning with a class for leaders" ${ }^{3}$ since there are many complications to

\footnotetext{
${ }^{1}$ Schwanz, 89 .

${ }^{2}$ Ibid., 90.

3 Ibid., 177 .
} 
such an approach. Leaders will receive a lot of information but will be robbed of practical experience. This approach is teacher-centered rather than student-centered. ${ }^{1}$ Trained in this way, the group leaders would experiment on their first groups rather than providing necessary leadership. In addition, not all listeners will turn out to be good leaders since they cannot discover during the seminar whether they are suitable for this work or not. Furthermore, it is easier to forget a lot of things while being simply a passive listener.

However, most of the pastors who are using this method of training are acquainted with the commonly known fact that people learn more by doing than through any other means. At the present time, it is known that after three days people remember only 10 percent of what they heard, 3050 percent of what they saw, 70 percent of what they said, and 90 percent of what they did. ${ }^{2}$ This points to a necessity to use such a method where a trainee is involved in the process of learning and participates meaningfully in it (learn-by-doing method). ${ }^{3}$ Aware of this, modern trainers

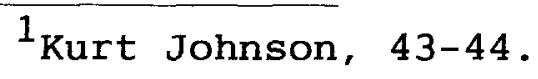

2 Judy Hamlin, Welcome to Your First Small Group (Wheaton, IL: Victor Books, 1993), 19.

3 John Mallison, Creative Ideas for Small Groups in the Christian Community (Sydney, Australia: Renewal Publications, 1978), 15. 
usually do not use the seminar method in its pure format but combine it with discussions and some group experiences. This, of course, gives the trainees some flavor of a smal1group ministry. However, it never allows them to experience it in full measure because of the time limits. Thus, the future leaders graduate from the training seminar often half-prepared, with theoretical knowledge rather than practical knowledge. This method can be called a seminar plus a limited group experience.

The third approach to the training of home-church leaders is a combination of both. The future leaders are gathered in a group and trained by the pastor primarily through the experience of the real group for twelve weeks. However, each training session has an additional thirty minutes after the meeting where an analysis of the meeting is done and some information is shared. These potential leaders are expected to commit themselves to leadership responsibilities in small groups at the end of the training session. Both the first and the third approaches advocate the training of small-group leaders through the real-group experience. "The very best place to train group leaders is in a healthy group." 1 "On-the-job training is best." 2 This method can be called parallel group and seminar experiences.

\footnotetext{
${ }^{1}$ Schwanz, 93 .

2 Ibid., 119.
} 


\section{5}

usually do not use the seminar method in its pure format but combine it with discussions and some group experiences. This, of course, gives the trainees some flavor of a smallgroup ministry. However, it never allows them to experience it in full measure because of the time limits. Thus, the future leaders graduate from the training seminar often half-prepared, with theoretical knowledge rather than practical knowledge. This method can be called a seminar plus a limited group experience.

The third approach to the training of home-church leaders is a combination of both. The future leaders are gathered in a group and trained by the pastor primarily through the experience of the real group for twelve weeks. However, each training session has an additional thirty minutes after the meeting where an analysis of the meeting is done and some information is shared. These potential leaders are expected to commit themselves to leadership responsibilities in small groups at the end of the training session. Both the first and the third approaches advocate the training of small-group leaders through the real-group experience. "The very best place to train group leaders is in a healthy group." 1 "On-the-job training is best." 2 This method can be called parallel group and seminar experiences.

$$
\begin{aligned}
& { }^{1} \text { Schwanz, } 93 . \\
& 2_{\text {Ibid., }} 119 .
\end{aligned}
$$




\section{6}

Therefore, it follows that the learning process should include trainees as active participants. As Martha Leypoldt says, the learning should be a cooperative task where a leader is a teacher and a learner, and participants are both learners and teachers. 1 "The leader, therefore, will want to teach in such a manner that the learner is given opportunity to make his own decisions, recognizing that to learn effectively a person must take responsibilities and be actively involved in the teachinglearning process." 2 To achieve a high level in the teaching process, there should be different methods of two-way communication employed. Leypoldt presents forty possible ways that can be combined to comprise more than one hundred. 3

The parallel group and seminar method of training is suggested for the Euro-Asia Division. However, it seems that the first method also can be very productive in places where some small groups have already been functioning. One should not forget that initial training in any approach is just a beginning. The future training should be realized through weekly meetings with the coordinator and from time

\footnotetext{
${ }^{1}$ Martha M. Leypoldt, 40 ways to Teach in Groups (Valley Forge, PA: Judson Press, 1970), 19.

2 Ibid., 15 .

3 Ibid:, 37-116.
} 
to time, additional retreats for layleaders. Nevertheless, it is the responsibility of the trainer to choose the best possible way to provide the initial training.

\section{Training Schedule and Suggested Structure}

This section suggests the training schedule for the first year of launching a house-church ministry in a congregation and a model for the leadership structure.

\section{Training Schedule}

Since the goal is to develop the integrated support system for home churches, one of the primary tasks is to inspire the congregation with vision. The training schedule is suggested with this idea in mind.

There are five major stages in the training schedule: (1) planning stage, (2) developmental stage, (3) launching stage, (4) outreach and the second-term training stage, and (5) multiplication, evaluation, and celebration stage.

\section{Planning Stage}

The main goals for this stage are to communicate the vision of a home-church ministry to the members of the congregation and to involve them in the planning process, to develop a plan of ministry for this particular church, and to recruit the first group of potential leaders.

Main activities for this stage are the formation of a Support Group (several people close to the pastor who are 
the first to know his vision of the small-group church and who commit themselves to support him through prayers and advice); preparation of the congregation through a series of sermons; and the organization of a Ministry Team, which will develop a plan for a home-church ministry in the congregation and recruit potential home-church leaders.

The duration of stage 1 is two months. During the first month the pastor forms a Support Group, begins the series of sermons, and organizes a Ministry Team. The second month the pastor continues to share his vision with the congregation, and the Ministry Team develops a plan for this ministry in the congregation. As was mentioned in chapter 3, it is very good if church leaders are included in the Ministry Team. As Schwanz says, "When (and until) layled small groups become the vision and the heart of the church leaders, they will never be a priority for the church body." 1 By the end of two months a small group of potential leaders is formed. The names of the future leaders are decided by the Ministry Team on the basis of agreed characteristics.

\section{Developmental stage}

Major goals for the second stage are to finish the development of a small-group strategy for this church, to

\footnotetext{
${ }^{1}$ Schwanz, 78 .
} 
identify those who desire to become hosts and members of the first home churches, and to train the first leaders.

Main activities during this stage for the pastor are to continue the communication of the vision to the people, and to train a small group of the first leaders. ${ }^{1}$ If the number of home-church leaders exceeds ten, they can be divided into two smaller groups.

The main work for the Ministry Team during this stage is to clarify all details about the ministry for the church and to match volunteer participants and hosts of the first home churches with the names of the leaders on the basis of common interests as was described in chapter 3 . The advice to start small should be remembered. "The results will not be good if churches try to get as many people as possible into small groups during a three-month emphasis." 2 Schwanz calls this approach of beginning small a principle of the mustard seed ${ }^{3}--"$ We must keep our vision big but start small." 4 Thus, there is no need for large numbers of recruited leaders and hosts in the beginning. The duration of stage 2 is three months.

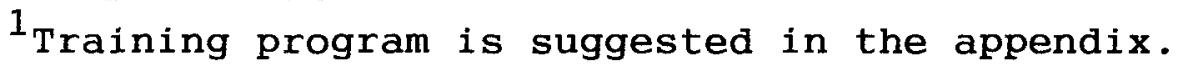
${ }^{2}$ Schwanz, 180 . 3 Ibid., 89 . ${ }^{4}$ Ibid. , 181 . 


\section{Launching Stage}

The first major goal for this stage is to start the first home churches and build meaningful relationships among their members. The second goal is to develop assistants for the group leaders within the groups. The third goal is to plan formation of peer groups if they have not been organized during this stage.

Main activities include home-church meetings, work of the Ministry Team, supervision of the small groups, and weekly meetings of the pastor with the group leaders. The latter activity should become a preparation time for the next house-church meeting. During that time the leaders "share life, pray for each other, and discuss the same lesson outline they will be using" ${ }^{1}$ next week.

It is expected by some that a small group will multiply by the end of the third month. However, the first three months are very much needed for the establishing of strong relationships among the group members themselves. In addition, the home-church leaders need this time to develop their assistants within the groups so that there will be future leaders when the present groups multiply. Thus, it is suggested that home-church leaders focus on the internal activities rather than on the external activities of outreach and multiplication of groups during this stage.

$$
{ }^{1} \text { Ibid., } 94
$$


Otherwise, premature groups with premature leaders can multiply, which is very destructive, especially in the beginning of a home-church ministry. Nevertheless; it should not be concluded that the groups should be strictly closed to guests during this stage.

The Ministry Team should help the pastor to supervise the work and to develop the plan of transition to the house-church ministry built around the geographical principle.

The duration of the launching stage is three months.

Outreach and Second-Term

Training stage

Major goals for this period are to involve members of home churches in outreach and to train the assistants.

The main activities for house-church members are to establish missionary goals and work with target people. Neighbour states that groups usually stagnate after six months if they have not multiplied. ${ }^{1}$ It would be incredibly successful if every home church multiplied within six months. However, practical experience shows that it is often not the case for every small group. Schwanz reports that throughout several years of observation; the average time for multiplication is about six months, although some need three or four and others nine or twelve months. "It is

\footnotetext{
${ }^{1}$ Neighbour, The Shepherd's Guidebook, 113.
} 
not the size of the group that determines its ability to multiply; it is its health." 1 Thus, since the first three months are suggested for building relationships inside the home church itself, the other three should focus on work outside the group. Even if multiplication does not occur, the missionary outreach will definitely prevent the group from stagnation.

The pastors's major activity is to train the second group of home-church leaders who will take responsibility over those new groups that will be formed. These future leaders are assistants who come to the training session from the groups as Schwanz suggests. ${ }^{2}$ Thus, they have already had practical experience. However, the same method of training as with the first group of leaders is still suggested. In addition to this main activity, the pastor should continue his weekly meetings with the group leaders. He should also communicate to the church the established goals and the progress made.

The main activity of the Ministry Team is to develop the evaluation form and begin to gather information for it. The duration of stage 4 is three months.

${ }^{1}$ Schwanz, 145 .

2 Ibid., 158 . 
Multiplication, Evaluation, and Celebration Stage

The major goals for this stage are to multiply some groups if they are ready, to complete evaluation, and to celebrate with the congregation the progress the housechurch ministry has achieved.

One of the main activities of this stage is to multiply those groups that are ready for it. This process includes defining which of the group members want to stay with which ones, finding hosts, introducing new leaders, and starting separate meetings. Another activity is the completion of the evaluation. If the planning stage started on the first month of the year, then this stage would come in the last month of the year. Thus, the completed evaluation, which is presented to the church, will cover the activities for the whole year and can be very useful for those who have not joined any group yet.

It may be necessary to appoint two section leaders if the number of the home-church leaders is considerably enlarged. The pastor and the Ministry Team can choose them from the group of the first-trained home-church leaders or from the Ministry Team itself. It seems that someone with the personal experience of leading a house church is preferable. In this case, it should not cause any deficiency in the number of the group leaders since not all the groups are expected to be multiplied, and by then the 


\section{4}

assistants should have already been trained. Then, these section leaders conduct weekly meetings with the home-church leaders. The pastor meets weekly with the section leaders and also conducts a common gathering of all home-church leaders once or twice a month in order to continue the training process. These common meetings should become meetings of prayers ${ }^{1}$ and "vision," "huddle," and "skill."2 The last of the main activities of this stage is a celebration with the church for the progress of the housechurch ministry. It should be a special meeting where personal testimonies of the group members and leaders are shared, results of the evaluation are reported, and the challenges and future goals are presented. As was mentioned in chapter 3 , such meetings should be conducted on a regular basis every six or eight months.

The duration of this stage is one month.

In view of the suggested integrated system, one should be prepared to realize that the transition into this pattern takes time. As Neighbour says, it "will require at least two to three years to take root." 3 He also warns people not to expect rapid growth "until the second or third

$1_{\text {Dossman, } 56 .}$

${ }^{2}$ Carl F. George, Prepare Your Church for the Future (Grand Rapids, MI: Fleming H. Revell, 1992), 135.

${ }^{3}$ Neighbour, where Do we Go from Here? A Guidebook for the Cell Group Church, 75 . 


\section{5}

generation of converts has matured enough to enter leadership positions." 1

As was mentioned above, the integrated system involves 80 to 90 percent of the congregation. A special approach can be taken to those 20 or 10 percent left. They can be people who do not feel comfortable joining the groups, or busy church members already heavily involved in different activities. There is some advice for this matter. Floyd Schwanz points out that if the pastor wants to implement a small-group ministry in his church and have it be successful, he should encourage all already-formed task groups "to move up on the nurture scale." 2 Roberta Hestenes also gives good advice on how to turn church committees into nurturing groups. 3

\section{Suggested Structure}

As was stressed above, the integrated support system for home churches is suggested for the Euro-Asia Division. The leadership structure of a small-group church is more or

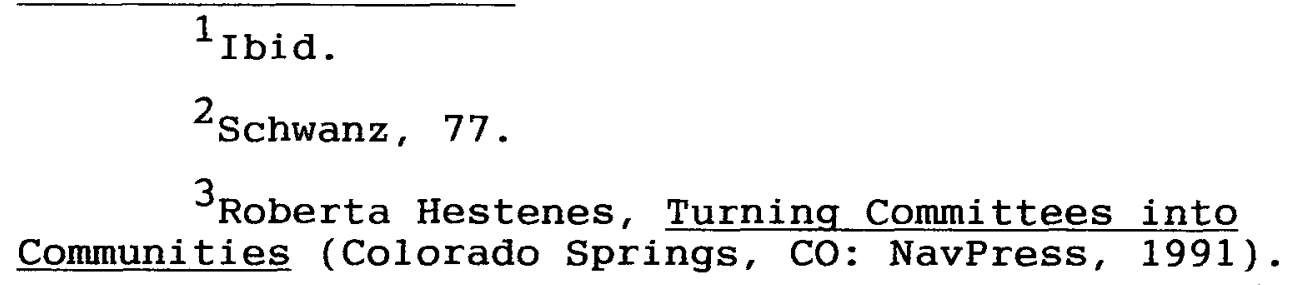




\section{6}

less identical for every congregation that involves the majority of its members. ${ }^{1}$

In the beginning the structure is very simple:

1. The senior pastor

2. Support Group and Ministry Team

3. House-church leaders (and assistants).

By the end of the first year, some groups are expected to be multiplied and additional leaders to be trained. Thus, the leadership can be enlarged and the group of section leaders may replace the Support Group and Ministry Team:

1. The senior pastor

2. Section leaders

3. House-church leaders (and assistants).

With the further development of the house-church ministry, the structure can look as follows:

1. The senior pastor

2. District leaders (each of them supervises 5-10 section leaders)

3. Section leaders (each of them oversees 5 to 10 house-church leaders)

4. Home-church leaders (and assistants, each team works with 3-12 members).

${ }^{1}$ Galloway, 127 ; Hurston, 68-69; Neighbour, where Do We Go from Here? A Guidebook for the Cell Church, 76, 194196; Schwanz, 82-83. 
It is important that at every level apprentices be developed. This should be a strong priority for each pastor to develop the next group of leaders through apprenticeship training. Schwanz stresses this point, describing the leadership structure of small groups in the church: "At each level of leadership there is someone in training, someone who is learning to do what the leader does." 1

With the progress of house-church ministry ${ }^{2}$ the pastor's main responsibilities will be: supervision of the growing network of home churches, training of new leaders, ${ }^{3}$ and involvement in evangelistic activities. As George says:

A pastor forges an authentic ministry by modeling contact segments of society: the unsaved community, the church cell group, and the leaders of cell groups. At every point, a minister's involvement in a cell makes a desirable statement, but the major time and energy investment must be in the training of leadership.

This connects very well with E. G. White's position: "The best help that ministers can give the members of our churches is not sermonizing, but planning work for them.

${ }^{1}$ Schwanz, 83 .

${ }^{2}$ Eventually, the progress of house-church ministry will result in new congregations. The senior pastor can supervize the growing number of churches in the city through weekly and monthly contacts with group leaders, section leaders, and district leaders.

$3_{\text {Kurt Johnson, 82-83. }}$

${ }^{4}$ George, Preparing Your Church for the Future, 98. 
Give each one something to do for others. . . And let all be taught how to work." 1 She continues:

Ministers should be educators who understand and appreciate the needs of humanity. They should encourage the church members to obtain a practical knowledge of all lines of missionary work, that they mày be a blessing to all classes of people. They should be quick to discern those who appreciate questions relating to spiritual life, who have tact and ability to watch for and care for souls as those who must give an account. They should assist these to organize the working forces of the church, so that men, women, and youth of various temperaments, in various callings and positions, will take hold of the work that must be done, bringing their God-given talents into most solemn service for the Master.

We know from past experiences in our Division that poorly supervised groups have acted independently, taught strange teachings, and even joined other religious groups. In order to prevent such practices in the future the model outlined above stresses pastoral supervision of all levels through weekly or monthly meetings with group leaders, section leaders, and district leaders. Those weekly and monthly meetings are a vital part to ensure that groups do not develop such problems.

\section{Selection of Home-Church Leaders}

This section suggests a method of selection for the home-church leaders and focuses on special qualities needed for this job.

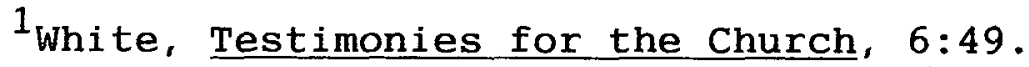
${ }^{2}$ Ibid., $6: 302$.
} 
The Method of Selection

Since recent times social psychology has held "the view that leadership is a set of learned skills rather than a set of characteristics bestowed on one person alone." 1 This has certainly influenced the image of a successful church leader, which for years was built on the requirements of possessing leadership "charisma." 2 Thus, the idea has come about that leadership is "a function rather than a special kind of personal style, ${ }^{3}$ and it has become commonly held that nearly everyone can learn to perform this function. As was described above, the concept of leadership is certainly broader than just a personal style; however, it also is not limited to just a function. Every person brings some personal characteristics into the function that he or she performs and influences people he or she has contact with. While it may not be very important for some jobs, this is not the case with leadership. Furthermore, it becomes even more crucial when it comes to Christian leadership. As Erich w. Baumgartner well describes it:

Leadership is basically a process of influence. Christian leaders influence through their spirituality and character as well as their words and actions. Bible knowledge and preaching skills can be developed through

\footnotetext{
${ }^{1}$ Nathan $W$. Turner, Effective Leadership in Small Groups (Valley Forge, PA: Judson Press, 1977), 21.

${ }^{2}$ Ibid.

3 Ibid. , 28.
} 
training programs, but how do you teach values and motivations?

It is interesting to note in this context that Christian teaching of spiritual gifts does support this view. Although all believers are royal priests, not all have the spiritual gift of a pastor. The very image of the church as the Body of Christ demonstrates that not all Christians can be equally successful in the same role. Thus, there should be a careful selection of promising people for the position of the home-church leader. As Baumgartner continues, "More than any other variable, leadership selection conditions the outcome of a training program. Train Christians who already show leadership potential. Don't try to turn non-leaders into leaders through a program. It does not work." 2

Therefore, it is suggested that a Ministry Team can agree on special characteristics needed for a home-church leader. Then, they should search through the membership list for adequate candidates. They do not need a big group for initial training. It is better to have a small number of potentially powerful leaders. The advice to start small should also be remembered. These chosen people should be recruited by the pastor or a member of the Team. If they

\section{${ }^{1}$ Erich W. Baumgartner, "Developing Leaders on the} Frontier," Adventist Frontiers, May 1996, 3.

2 Ibid. 


\section{1}

accept the invitation, a special meeting with all members of the Ministry Team should be scheduled. After that, they can be included in the training group.

With the development of home churches in the congregation, a slightly different procedure should be used. Home-church leaders should watch carefully for the development of their assistants. They should encourage people with needed characteristics toward this role. Once such an assistant is developed, they should promote this person to the Ministry Team and then the procedure is repeated.

Thus, obviously, a home-church leader should be somebody suitable for such a work. Necessary qualities for this position are discussed below.

Qualities Needed for a Home-Church Leader

There are certain characteristics many consider important for a small-group leader. In this section, these qualities are classified according to three dimensions suggested by Arnold: relationship to God, personal life, and relationship with others. 1

\section{Relationship to God}

A home-church leader must be a person with a strong relationship with God, and good knowledge of the Bible and

\footnotetext{
${ }^{1}$ Arnold, 59-67.
} 
church doctrines. Although these characteristics are interconnected, there are still some distinctions.

To have a strong relationship with God means, first of all, to have regular devotions with Jesus. A future home-church leader should perceive his daily relationship with Jesus as the most important responsibility and make it a priority in his or her daily schedule. There should also be evidence that this relationship with Christ is growing (2 Pet $3: 18), 1$ and that the person has a commitment to grow further in this relationship with Jesus. ${ }^{2}$ Then, when he or she becomes involved in the leadership of a group, it will not be difficult for such a person to follow E. White's advice that "ministers should devote time to reading, to study, to meditation and prayer." 3

This relationship with Jesus should also become evident for other people through, as Cerna expreses it, "a totally committed Christian life." 4 The commitment to Jesus Christ $^{5}$ should be seen through whatever the person says or does. Then, it also should be seen in the person's

$1_{\text {Neal F. McBride, How to Build a Small Groups }}$ Ministry (Colorado Springs, CO: Navpress, 1995), 111.

${ }^{2}$ Whalion, 44 .

3Wite, Testimonies for the Church, $4: 412$.

${ }^{4}$ Cerna, The Power of Small Groups in the Church, 54. ${ }^{5}$ Dossman, 52 . 


\section{3}

attitudes, actions, and willingness to do God's will. The person should believe in God's control over everything, and give God permission to gain it over his personal life. ${ }^{1}$

Patty Pell touches on the same issue by stating that a group leader should live "as sheep and shepherd." This means to be a shepherd over members of the home church and also "allow Jesus to shepherd" him or her. 2 This seems extremely important since, "as we enter into leading a small group of people that God has brought together, we need to be closely connected to God to hear his directions and follow his lead." 3 She also shows the direct connection between a relationship with God and the ability to do the will of God. "In the same way we will be able to do all that God asks us to only if our self-worth comes from being a child of God."4 This relationship with Jesus should be so vital that, as Galloway adds, a leader should be "able to give a clear direct testimony to what Christ has done" in his own life. 5 Hurston says that it is a direct connection between whether a person has a clear, specific testimony and whether he or

$1_{\text {Arnold, } 59-61 .}$

${ }^{2}$ Patty Pell, "The Growing Leader," in Small Group Leaders' Handbook: The Next Generation, ed. Jimmy Long (Downers Grove, IL: InterVarsity Press, 1995), 164.

3 Ibid., 166.

${ }^{4}$ Ibid., 162 .

${ }^{5}$ Gal loway, $150-151$. 
she becomes an evangelism-oriented leader. "Leaders who have personally experienced the power of God in healing, deliverance, or miracles are best able to communicate the power and goodness of God to others." 1

Another main quality is to have a good knowledge of the Bible and church doctrines. E. G. White stresses the importance of this as follows: "A great injury is often done our men by permitting them to commence to preach when they have not sufficient knowledge of the Scripture to present our faith in an intelligent manner." 2 William Riley also adds that a group leader should have a good understanding of the Bible, its purpose and context, of the church doctrines and understanding of people, and where they are in their approach. 3 E. G. White also stresses the importance of understanding the truth for this time and a practical application of it:

Ministers should be examined especially to see if they have an intelligent understanding of the truth for this time, so that they can give a connected discourse upon the prophecies or upon practical subjects. If they cannot clearly present Bible subjects they need to be hearers and learners still.

\footnotetext{
$1_{\text {Hurston, }} 73$.

2 White, Testimonies for the Church, 4:405.

3William Riley, The Bible Group: An Owner's Manual (Dublin, Ireland: Mount Salus Press, 1983), 16-17.

${ }^{4}$ White, Testimonies for the Church, $4: 407$.
} 
In the context of these characteristics, the advice of the apostle Paul that a church leader should not be a new believer ( 1 Tim 3:6) is very reasonable. People obviously need time to take root in their new faith, time to develop personal relationships with Jesus, and time to show that these relationships are steady and bearing fruit. Sometimes a new convert is chosen to lead a small group because of his or her strong natural leadership traits. However, it is noted that in such cases, groups often get off "to a weak start and never jell," or start "with enthusiasm and fade like a shooting star." 1

As was shown in chapter 1, the proportion of new and old members in the Euro-Asia Division is more than unequal. Thus, it might be a real temptation to involve new believers in leadership of home churches in many places of this Division. However, in this case, it is useful to look at the experience of some presently growing churches. The church of Yonggi Cho gets, as he reports it, new leaders for home cells from new Christians. ${ }^{2}$ Nevertheless, before they become the cell leaders, they should be appointed as deacon or deaconess. ${ }^{3}$ And "to be a deacon or deaconess, one must have been a faithful member of the church for at least two

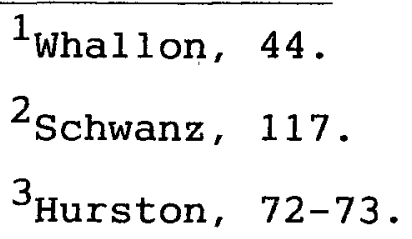




\section{6}

years" alongside with other requirements. 1 Neighbour states that neither new believers nor problematic people "can become involved in ministry until after they are nurtured and matured." 2 Schwanz says that for years he oversaw the work of new Christians and pioneer Christians working together as a team. "They encourage each other in unmistakable ways. The new Christians need the wisdom of the pioneer; the pioneer needs the excitement of the new Christian." 3 Thus, if somebody wants to have Christian. leaders solidly developed in the faith, he should give them some time to grow and some people to model.

Thus, there are several characteristics in the first group of qualities ("Relation to God") for the home-church leaders: deep and growing relationships with God seen through regular devotions, committed Christian lives, willingness to do God's will, strong belief in God's control over everything, personal testimony of what God has done in their lives; a good knowledge of the Bible teachings and church doctrines, and the ability to present and apply them to modern life. And the last one is spiritual age--the future leader should not be an immature recent believer.

1 Ibid., 68 .

${ }^{2}$ Neighbour, Where Do We Go from Here? A Guidebook for the Cell Group Church, 214-215.

${ }^{3}$ Schwanz, 117. 


\section{Personal Life}

There are also several personal characteristics that are considered by many as important for the group leader.

One of the first characteristics is character.

Although "secular theory has little to say about the character of a leader, "I it is very important from the Christian point of view. E. G. White speaks of such characteristics for ministers as the proper government over themselves, and good influence and character. ${ }^{2}$ It is interesting to note that the personal character of the pastor is named as one of the most important characteristics by lay members. They want to see people in leadership they can trust. 3 Pell says that "a leader may have charisma and talent, but if that leader's character is not trustworthy, full of integrity and strong, his or her influence is limited." 4 she points to the "integrity no matter what" 5 and continues: "Our character has a tremendous influence on our small groups. If we are inconsistent and dishonest, our groups will feel the impact. Our character is more important to our groups than our techniques and leadership

${ }^{1}$ David L. McKenna, Power to Follow, Grace to Lead (Dallas: World Publishing, 1989), 33.

2 White, Testimonies for the Church, $4: 407$.

3 Weems, 125 .

${ }^{4} \mathrm{Pel} 1$, 162 .

${ }^{5}$ Ibid., 163 . 
skills." 1 Schilt notes that all characteristics for church leaders given by Paul in 1 Tim 2:2 (except for the ability of teaching) have to do with the character of the person. ${ }^{2}$

Some character traits are considered of primary importance and are set apart by some authors. Among such are honesty and faithfulness in small things as well as in big ones (Luke $16: 10$ ). ${ }^{3}$ E. G. White also makes the following statement:

When responsibilities are to be entrusted to an individual, the question is not asked whether he is eloquent or wealthy, but whether he is honest, faithful, and industrious; for whatever may be his accomplishments, without these qualifications he is utterly unfit for any position of trust.

Interestingly enough, research shows that honesty was repeatedly named by thousands of people as the first most important quality for a secular leader too. 5

Another specified character trait is humility. Arnold shows a direct connection of this virtue with "a correct understanding of God, others and self." 6 "Only truly humble people can possess the confidence to help

1 Ibid.

${ }^{2}$ Schilt, 55 .

${ }^{3}$ Arnold, 63; Baumgartner, 3; Hurston, 67; McBride, How to Build a Small Groups Ministry, 111.

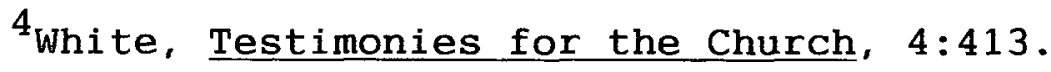

${ }^{5}$ Kouzes and Posner, 16-17.

6 Arnold, 60 . 
others because they know what they have to offer and are not scared to give themselves." 1 "Too many leaders compete with each other, seeking the world's approval instead of rooting their motivation in God." 2 This includes an awareness of personal strengths and weaknesses with healthy selfconfidence. 3 In addition, being willing to be led, stressed as an important characteristic for a group leader by cerna, 4 is also typical for humble people.

Some think that it is very crucial for a small-group leader to have "a teachable spirit" 5 or, as Riley says, to be a learner, 6 and to be a good communicator. 7 In other words, a small-group leader should be a good learner and a good teacher.

Enthusiasm and willingness to take a risk are pointed out by some as also significant qualities for small-group leaders. 8 In particular, they should be "enthusiastic in

$1_{\text {Ibid., } 61 .}$

2 Ibid.

$3^{\text {Ibid. }}$

${ }^{4}$ Cerna, The Power of Small Groups in the Church, 54.

${ }^{5}$ Ibid. See also McBride, How to Build a Small Groups Ministry, 111.

6 Riley, 17 .

7 Ibid.

${ }^{8}$ Gall loway, $150-151$. 
witnessing and in their Christian walk and have a positive attitude about divine intervention in human problems." 1 McBride adds that they also should have a vision for smallgroup ministry and be excited about their participation in it. ${ }^{2}$ Some call it being devoted to the task. This is crucial since vision is one of the leader's responsibilities that cannot be delegated, as was mentioned above. It inspires others to move forward. Arnold also notes that wise risk-takers usually "are the ones who are moving ahead in relationships, at work and in personal growth." 3

Another required characteristic is to have enough time, means, and energy for this ministry. ${ }^{4}$ Arnold suggests that every church should set a definite amount of time for spending on a home-church ministry. In this way, leaders would know the church's expectations and agree to take the job only if it did not damage their health and family relationships. ${ }^{5}$

It is also advisable to acquire additional qualities. Pell advises everyone to acquire skills for managing and

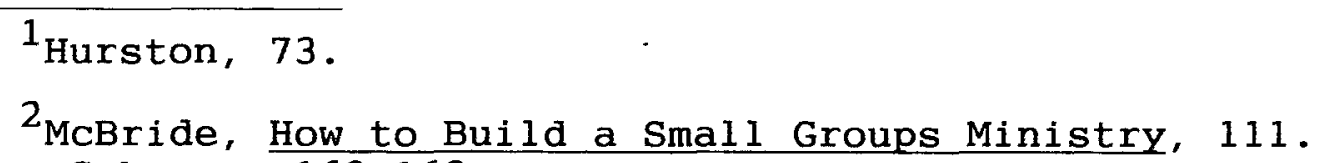

3 Arnold, 62 .

${ }^{4}$ Galloway, 150-151; Arnold, 67.

5 Arnold, 67. 
organizing one's time before becoming a leader of a small group. ${ }^{1}$ It is interesting that E. White also points to the importance of order and regularity in the success of a minister's work. She says: "If order and regularity are essential in worldly business, how much more so in doing work for God." 2

In addition, Pell points to healthy living as an important principle in the life of the leader. "When we do not take care of our bodies by living within our limits, we hinder God's work in the long run because we must quit the race early." 3 she also adds that we should remember that "we are in a marathon and not a sprint, so we must live accordingly. " 4

Thus, a home-church leader should be a person of Christian character, honest and faithful in small things, humble, teachable, enthusiastic about God's leadership and a small-group ministry, with adequate time and means. It is good if he or she has some management skills and lives according to healthy principles.

$1_{\text {Pell, 173-175. }}$

2 White, Testimonies for the Church, $4: 412$.

$3 \mathrm{Pel1}$, 172 .

${ }^{4}$ Ibid. See also White, Testimonies for the Church, $6: 376-377$. 
Relationships with Others

Qualities of a home-church leader in relation to

others can be viewed from two angles: attitudes toward the people and attitudes toward the church leadership.

A small-group leader should have genuine love for people $e^{1}$ and be willing to serve them or, as some express it, to have a "commitment to get involved in other people's lives." 2 As Galloway says, a leader should be not only task-oriented but people-oriented as well, positively motivating people and building their relationships on the basis of love. ${ }^{3}$ McBride states that he or she should enjoy serving people (Gal 5:13) and thus "people who don't enjoy servant leadership shouldn't be asked or coerced into leadership." 4 Griffin adds that people who "had shown a willingness to serve elsewhere" are likely to be effective as servant leaders. 5 This willingness to serve people should manifest itself in his or her desire to facilitate people's growth and be "sensitive in listening." 6 A leader also should be a person who is able to delegate

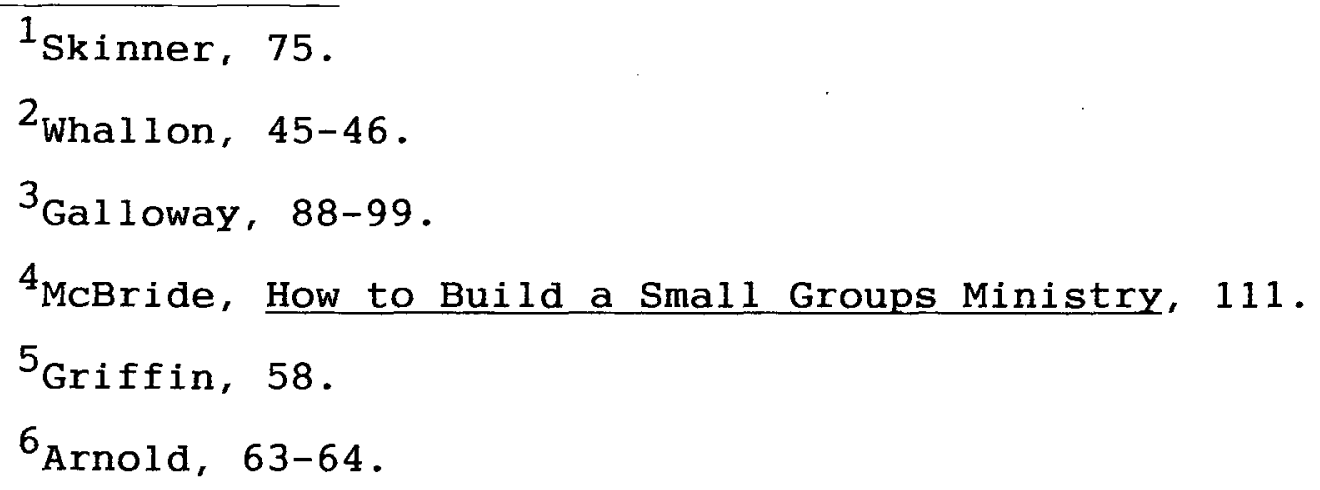




\section{3}

responsibility and share leadership functions ${ }^{1}$ or, as McBride says, be a team player. ${ }^{2}$ weems points out that behavior and quality of relationships of trust and respect with people influence one's credibility. 3 In this connection, it is important to note that one of the major tests small-group leaders should pass is their family relationships. "The way we relate to our families is vital" 4 since it shows the way we usually treat people who are close to us.

It is also important to look at the attitude of the person to the church leadership. As Hurston states, this person should show "continued submission to authority." 5 Thus, in regard to relationships with others, a homechurch leader should have genuine love for people, a willingness to serve them, and respect for the church leadership.

\section{Summary}

In summary, there are several people who can train the leaders: a layperson, an appointed staff member, the

1Turner, 12; Arnold, 66 .

${ }^{2}$ McBride, How to Build a Small Groups Ministry, 112 .

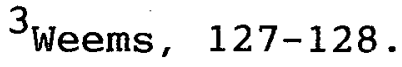

${ }^{4}$ Ibid., 171 .

$5_{\text {Hurston, } 73 .}$ 
pastor himself, or an invited expert. The first three options reflect three different support systems for a smallgroup ministry. The integrated support system with the pastor as a key person in the development of this ministry and training the leaders is suggested. It is the only system that can involve to 90 percent of the congregation in spiritual growth and outreach.

It is very important to notice which kind of leadership concept the trainer will pass on to the future home-church leaders during the training process. He must be aware of the necessity to provide real leadership, and, at the same time, to be a facilitator. It is important for the pastor himself to understand that the leadership concept is broader than just one preferable style.

There are several methods of training the group leaders: the group experience plus a seminar, a seminar plus a limited group experience, and a parallel group and seminar experience. The last method is suggested for the training of home-church leaders in the Euro-Asia Division.

Five stages are suggested for the involvement of the congregation in the small-group ministry, training the group leaders, and launching the first home churches. The leadership structure after its full development would be represented by the senior pastor, district leaders, section leaders, and home-church leaders. 
The selection of the group leaders is a very important issue since their function includes Christian influence and not only exercise of leadership skills. There are several characteristics that are considered important for a home-church leaders. They should not be new converts but people with a mature, deep relationships with God, which are manifested in their personal life, and they should have a good knowledge of the Bible and church doctrines and the ability to apply them to the modern life. They should be people of good Christian character, honest and faithful in small things, humble, teachable, enthusiastic about God's leadership and small groups, with time, means, and energy for this ministry. It is good if they would have some managing skills and be living according to healthy principles. They also should be people with a genuine love for others, a desire and willingness to serve them, and a respect for the church leadership. 


\section{CONCLUSIONS AND RECOMMENDATIONS}

The results of this study could be presented as follows :

Chapter 1 shows that the Adventist message came to Russia more than one hundred years ago. In spite of tremendous hardships, persecutions, and suffering of the believers in this part of the world, the Adventist church grew under God's leadership. At the beginning of the century (1900), there were 1,037 members; in 1929, there were 13,547 members comprising twenty-nine nationalities; in 1985, there were 31,305 Adventists in the territory of the USSR .

The decade of 1985-1995 was the long-awaited answer to the prayers of many believers in this country. It brought religious freedom and new opportunities for the church. This decade can be divided into two significant periods: a period of transition (1985-1990) and a period of public evangelism (1991-1995). During the first period, both the Soviet state and the Adventist church went through tremendous changes. A spiritual vacuum that existed in the hearts of miliions of Soviet people forced them to seek 
religious answers to the main questions of life. The Bible became a bestseller, and concerts of religious music or short religious programs were filled to overflowing. During this period, the Adventist seminary was built in Zaokski, Adventist broadcasts went on the air, and the Euro-Asia Division with five Union Conferences was formed. During the second period (1991-1995), hundreds of evangelistic crusades were conducted by foreign and local ministers throughout the Division. The largest crusades were conducted in Moscow by Mark Finley, in Nizhni Novgorod by John Carter, and in Kiev also by John Carter. Alongside the public evangelism; literature evangelism, youth evangelism, lay members' evangelism, and other methods were used to spread the gospel. However, public campaigns were the primary means responsible for the tremendous growth in church membership, which increased to 109,889 by the end of 1995 .

An analysis of this rapid growth of membership showed that it brought with it many challenges the church was not prepared for. Mass baptisms resulted not only in increases of membership but also in increased apostasies. The church could not provide adequate numbers of pastors or church buildings for its rapidly growing congregations. The lack of church buildings forced the church to rent public halls, which could not provide stability, and the needed church environment, worship atmosphere, or facilities for different 
departments. The lack of pastors caused a deficiency in pastoral care and much needed church support for the newly converted members. In addition, this analysis showed that new converts comprise approximately 78 percent of the total membership. At the same time, even with this rapid growth and public evangelism, Adventists comprise only about 0.04 percent of the total population of the Euro-Asia Division. A comparative analysis of the Union Conferences and attached fields of the Division showed that the former Russian Union Conference had the greatest number of accessions during this period and the highest rate of apostasy. The Ukraine had the greatest growth, but it is presently facing the challenge of assimilation of new believers since it also has the greatest need for pastors and church buildings. Belarus has the highest DGR for this decade; however, much needs to be done to keep these new members it has won. The Trans-Caucasus Mission and the Southern Union Conference have the smallest percentage of Adventists in their territories, but there the church faces the challenge of how to reach Muslims. Moldova is the Union Conference with the smallest ratio of non-Adventists per each SDA member. However, it is experiencing the same challenges as the other parts of the Division: lack of church buildings, lack of pastors, apostasy of new converts, and still millions of unreached people. This comparative 
analysis showed that these challenges are common for the whole Division and for each of its Unions or attached fields. It also pointed to the need for a specific strategy that can meet these great challenges.

Chapter 2 suggested a home-church approach as a possible solution for the challenges presented in chapter 1 . The results of the questionnaire conducted in the fall of 1995 showed two major reasons for apostasy of new converts, as seen by the church: the people have not built personal relationships with God and have not formed personal relationships with other church members. Studies show that these two reasons represent at the same time the two major groups of needs that modern people have. Home churches represent an excellent setting for meeting these needs, and thus can be an answer to the challenge of apostasy. It was also shown in chapter 2 that home churches can become efficient channels of pastoral care provided by lay members to each other. In this case, the challenge of inadequate numbers of pastors can be successfully addressed. Although the challenge of the lack of church buildings cannot be solved in a short period of time, home churches can play a crucial part during this period, helping new members to find their new identity and be developed as a church. It was also shown in chapter 2 that a home-church approach is a very effective means for reaching multitudes of unreached 
people, whether they are relatives or friends from oikos of believers, followers of non-Christian religions, or urban dwellers. The uniqueness of this approach is that it combines evangelism and follow-up, nurture and fellowship, leadership development and every member's involvement.

Chapter 3 presented guiding principles for starting a house-church ministry. It showed the necessity of deciding at the very beginning some crucial issues: the principle of involvement in the group, role of the pastor and congregation, size of the groups, and components of the house-church meetings. It was suggested that each church. that adopted a house-church approach has the goal to organize a home church in every district of a city, town, or village, and in the end, have most of the groups formed according to geographical and heterogeneous principles. However, it was proposed to start with a limited number of groups built around the common interests of the participants. The chapter discussed the necessity of personal involvement of the pastor in the home-church ministry if success is to be achieved. At the same time, good results can be achieved only if a congregation is prepared and involved in this work. Regarding the size of small groups, from three to twelve people is considered best. The home-church service should include four main components: nurture, worship, fellowship, and mission. All 
four are important and should be included in any format used for a home-church meeting. These four aspects provide opportunity for the church to accomplish three major tasks: to help church members build meaningful relationships with God, to establish strong relationships with each other, and to find the ways for building deep relationships with unbel ievers.

Chapter 4 showed that there are several people who can train the home-church leaders: a layperson, an appointed staff member, the pastor himself, or an invited expert. The first three options reflect three different support systems for a small-group ministry: the appendage system, the incorporated system, and the integrated support system. While the first two systems provide a limited involvement of members in house churches, the third one reorganizes the whole congregation into home cells. It is suggested that the Euro-Asia Division follow the model of the integrated system since it is the only one that blends every member's involvement and outreach. Then, the pastor should become a key person in the development of this ministry and in the training of the group leaders. The option of an invited expert is not the best in this practical approach. It was also shown in this chapter that it is very important which kind of leadership concept the trainer will pass on to the future home-church leaders during the training process. 
Misconceptions concerning leadership were presented, and the conclusion made that leadership is much broader than just one or another style of leadership. Although it is very important for the pastor and the group leader to be a facilitator, this is just one part of their job. The need for a strong leader, with vision, and ability to take responsibility for leading people toward the vision were introduced. Several methods of training the group leaders were also presented in the chapter: the group experience plus a seminar, a seminar plus a limited group experience, and a parallel group and seminar experience. The last method is suggested for the training of home-church leaders in the Euro-Asia Division. To involve the whole congregation and to launch a house-church ministry, five stages are suggested for the pastor: (1) planning stage, developmental stage, (3) launching stage, (4) outreach and the second-term training stage, and (5) multiplication, evaluation, and celebration stage. The leadership structure, after its full development, would be represented by the senior pastor, district leaders, section leaders, and home-church leaders. This chapter also dealt with the question of selection of the group leaders. Since their function includes Christian influence and not only exercise of leadership skills, a selection based on needed characteristics was suggested. The group leaders should not 
be new converts but people with a mature, deep relationship with God, which is manifested in their personal life. They should have a good knowledge of the Bible and church doctrines and the ability to apply them to modern life. It is very important that they should be people of good Christian character, honest and faithful in small things, humble, teachable, enthusiastic about God's leadership and small groups, and possess the time, means, and energy for this ministry. It is good if they would have some management skills and be living according to principles of good health. They also should be people with a genuine love for others, a desire and willingness to serve, and a respect for church leadership.

Thus, it is recommended that the Euro-Asia Division implement the house-church approach as a means to meet the present challenges of apostasies, the lack of pastors and church buildings, and the multitudes of unreached people. It is suggested that home churches be built on the basis of the integrated support system. The pastor should play a crucial and central role in the development and supervision of the house churches. The goal should be to form geographical heterogeneous groups in every district of a village, town, or city. The focus in the meetings should be on nurture and outreach as well as on worship and fellowship. 


\section{4}

Implementation of this approach in a local church should become the concern of the whole congregation. People from the congregation should decide what direction they will choose for this ministry and what kind of home-church leaders they want to see in leadership. Training of the group leaders is suggested, using a method of parallel group/seminar experience. It is very important for the pastors who are willing to start home churches in their congregations to be personally involved in the house-church ministry and to maintain a central role in the process of development, training, and outreach. 


\section{APPENDIX 1}

OUTLINE FOR A TWELVE-WEEK TRAINING PROGRAM

This appendix suggests a brief outline for a twelveweek training program for home-church leaders. It is not the purpose of this section to explain every concept, since they are well described in various books on small-group ministry or have already been mentioned in this dissertation. The training program is planned with the method of the parallel group and seminar experience in mind. The first seven chapters of Acts of Apostles are suggested for the inductive Bible study in this training program. 1

\section{Meeting 1. Precovenanting Stage. Building Bonds.}

Part 1. Getting Acquainted.

1. Welcome to the group participants. (3 min.)

2. Opening prayer by the leader. ( 2 min.)

3. Praise through singing. (10 min.)

${ }^{1}$ It seems that a Bible study of the Acts of Apostles can be very beneficial for the group leaders since it opens the very context of the first Christian home churches. Although the whole book will not be covered by the end of the suggested program, its study can be continued during the next sessions of leadership formation. 
4. Ice-breaking activity. (about $40 \mathrm{~min}$. )

"Where are the different places you have lived? Which one did you like the best? Why?" ${ }^{1}$ who was the person you felt closest to during your childhood? ${ }^{2}$ How large was your family then? How large it is now?

5. Introduction to the home-church meetings by the leader: brief description of the meeting's format, goals, and covenant which will be made during the next meeting. ( 5 min.)

6. Fellowship through a meal. Sharing expectations about a home-church ministry in the church. (20 min.)

7. Praise through singing. ( 5 min.)

8. Prayer by the leader (a slightly longer prayer than the first one. ${ }^{3}$ ) ( 5 min.)

Part 2. Analysis of the first meeting.

There are five important points to stress:

1. The importance of devoting time in the first meeting mainly to praise and getting acquainted. ${ }^{4}$

$1_{\text {Milton Adams, The Beginnings of Reaching out in }}$ Love: A Seven Week Introduction for a College or High School Smal1 Group (College Place, WA: Color Press, 1991), 5.

${ }^{2}$ Neighbour, The Shepherd's Guidebook, 144 .

3 Adams, 20 .

${ }^{4}$ Neighbour, The Shepherd's Guide Book, 114. 
2. The importance of prayerful preparation for the homechurch ministry by asking God's leading "in determining the direction of the group, and that the right people will be brought together." 1

3. The importance of a gradual involvement of everyone in prayer, especially since new converts are not used to praying in public. "The goal for small groups should be that people have a positive experience with the Lord and with one another." 2

4. The importance of creating a non-threatening but sharing atmosphere and opportunities to better know each other ${ }^{3}$ and cooperate with each other. "When an individual can share non-threatening areas of his or her life, an exciting step in group building has taken place." 4 As people "discuss solutions and physically help one another accomplish the goal, bonds are built between people of diverse backgrounds" and they begin to feel themselves as part of the group--part of the team. 5

${ }^{1}$ Schilt, 35 .

2 Ibid, 48 .

${ }^{3}$ Schilt, 35 .

${ }^{4}$ Denny Rydberg with Robin Dursch and Ken Beebe, Building Community in Youth Groups (Loveland, CO: Group Books, 1985), 18 .

5 Ibid. 
5. The importance of setting up the right expectations for the group meetings. The purpose of the group and tentative format for the next meetings should be developed before starting a group. 1

\section{Meeting 2. Covenant Stage. \\ Making a Commitment.}

\section{Part 1 .}

1. Welcome to the group participants. $(3$ min.)

2. Opening prayer by the leader. ( 2 min.)

3. Praise through singing. (10 min.)

4. Ice-breaking activity $(20 \mathrm{~min})$ :

Describe in short the day of your covenant with God or with your spouse (choose either one). What was the most important thing for you during that day?

Share your favorite promise of God or your favorite part of the marriage vows.

5. Bible study: Promise of the Holy Spirit is a part of God's covenant (Acts $1: 1-14)$. (25-30 min.)

6. Mission combined with the application of the Bible study $(10-15 \min ):$.

How can we be witnesses for Jesus?

Applying vs. 8, what are your Jerusalem, Judah and Samaria, and the ends of the earth?

${ }^{1}$ Schilt, 35 . 
7. Covenant making (when, where, how long; format of the meeting; attendance, participation, relationships; host, leader, vacancy for an assistant). (10 min.)

8. Closing prayer: short expressions of thanks. "Whoever wants to can offer a one-word prayer of thanks for whatever he is grateful for." 1 ( 5 min.)

Part 2. Analysis of the second meeting and an additional information.

There are five important points to stress:

1. A good portion of time in the second meeting again should be devoted to sharing questions and interaction among members with the purpose of building relationships. 2 2. Sharing questions are very helpful when they are connected with the Bible passage and the activities of the meeting .

3. No lasting relationships are possible without some kind of covenant. Success depends on the faithfulness of both sides to the covenant. Main points of the group covenant. 3 Two types of the covenant: written and verbal. Advantages of each one.

4. The importance of a special time for "mission" in a home-church meeting. Acts $1: 8$ is a good verse to lead

${ }^{1}$ Adams, 21 .

${ }^{2}$ Neighbour, Shepherd's Guide Book; 114 .

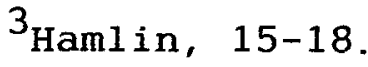


people to the idea of starting their own mission within their oikos. Concept of mission through oikos.

5. Non-threatening type of the first common prayer (closing prayer).

\section{Meeting 3. Exploration Stage. A Need \\ for the Right Leaders.}

Part 1.

1. Welcome to the group members and visitors. Introduction of visitors to the group. (3-5 min.)

2. Opening prayer by the leader. ( 2 min.)

3. Sharing of good and bad experiences of the last week. (5 min.)

4. Praise through singing. (10 min.)

5. Ice-breaking activity ( 8 min.):

"Who has had the biggest impact on your life? Why?" 1 Have you ever had a chance to say it to this person?

6. Bible study: Search for a right leader (Acts 1:15-26). (35-40 min.)

7. Mission and affirmation (discussion in two large groups): Tell about one person from your unchurched relatives or friends you think you have influenced in some kind of way. Name one of the qualities that you think may have a good Christian influence on people. Tell the person to your left about his or her strengths or gifts. (15 min.)

$$
{ }^{1} \text { Adams, } 6 \text {. }
$$




\section{1}

8. Prayer time: short petitions. "It should be explained again that people can pray once, more than once or not at al1." 1 (3-5 min.)

9. Closing hymn and shared prayer requests for the next week. ( 5 min.)

Part 2 .

There are six important points to stress:

1. The meeting presents a general format that should be followed in the weeks to come. The two previous meetings needed more time for building relationships. Changes in the format can be done from time to time, especially if the group decides to celebrate with a meal some special occasions such as birthday.

2. The importance of introducing visitors if they are in the meeting.

3. The importance of sharing good and bad experiences from the past week. "Since the group is like a family that meets once a week, each member is interested in the welfare of the family." 2 Cerna stresses the importance of praising God no matter what bad or good experience has happened. ${ }^{3}$ If somebody had problems during the last week but does not have

${ }^{1}$ Adams, 22 .

${ }^{2}$ Cerna, The Power of Small Groups in the Church, 72 . 3 Ibid. 
a prayer request at the end of the meeting, the leader can suggest that members pray for his or her problems during the next week.

4. Four steps in building community: history giving, affirmation, goal setting, fellowship and support. 1 "After revealing their inner selves during the opening up step, students need positive feedback to reassure them that others think they are still okay before they will consider sharing further." 2 The necessity to educate the group members in the importance of affirmation.

5. Help people catch the vision of oikos evangelism and help them see that they are able to do it. 6. Qualities for a home-church leader: relationships with God.

\section{Meeting 4. Exploration/Transition Stage. \\ Power of the Holy Spirit.}

Part 1 .

1. Welcome to the group members and visitors.

2. Opening prayer by the leader or a person from the group who is comfortable praying aloud and has been asked ahead of time.

3. Sharing good and bad experiences of the last week.

${ }^{1}$ Rodney J. Dean and Gary L. McIntosh, How to start or Evaluate a Small Group Ministry (Lynchburg, vA: Church Growth Institute, 1991), 48-49. 2 Rydberg, 19. 
4. Praise through singing.

5. Ice-breaking activity:

How did you become a Christian? (short stories)

6. Bible study: Power of the Holy Spirit (Acts 2:1-41).

7. Mission: Broader view on the community. What kinds of ethnic groups are represented in our community? What can the church do to reach them? What methods can be effective? In reaching what ethnic group (other than yours) do you feel you might be successful? (Common discussion).

8. Closing prayer: a new kind of corporate prayer: each person prays for the prayer request of the person on his or her right.

9. Closing hymn and shared prayer requests for the next week.

\section{Part 2 .}

There are six important points to stress:

1. A new person does the opening prayer. One more step is taken in corporate prayer. This way of prayer should not be threatening since every member has something to pray for. "Often times when people pray aloud once and find out nothing terrible happens, they begin to pray aloud regularly." 1

2. Sharing questions are still not threatening.

$$
{ }^{1} \text { Adams, } 25 .
$$


3. Focus on ethnic diversity of the community.

4. Four stages of small-group development: exploration, transition, action, termination. 1

5. The main force of a home-church ministry is the Holy Spirit. As Schilt says, "It is vital to remind ourselves that the key factor in successful Christian small groups is the Holy Spirit's work." 2

6. Qualities for a home-church leader: personal 1 ife and relationships with others.

\section{Meeting 5. Exploration/Transition Stage. Four Ingredients.}

Part 1 .

1. Community: welcome to the group members and visitors.

2. Worship: opening prayer by the leader or someone from the group.

3. Community: sharing of the last week's experiences.

4. Worship: singing.

5. Community: ice-breaking activity.

Share one experience from your life when you were in a desperate situation and somebody helped you.

6. Nurture: Bible study: Four ingredients (Acts 2:42-47).

\section{${ }^{1}$ Judy Johnson, "Stages of Small Groups," in Small} Group Leaders' Handbook, ed. Steve Barker (Downers Grove, IL: InterVarsity Press, 1982), 49.

${ }^{2} \operatorname{Schilt,} 43$. 


\section{5}

7. Mission: Powerful influence of good works towards unchurched people and church members. Reasons of apostasy. Importance of follow-up relationships. (Discussion in two groups.) Action (optional): visit or contact one member from this group during the next week and (or) take from the church office one address of an apostatized member and visit him or her.

8. Worship: closing prayer. "Pair off people and have them give their prayer requests to one another. Ask them to pray for their partners every day during the coming week." 1

9. Worship and community: closing hymn, shared prayer requests for the next week, follow-up for absent members, announcements.

\section{Part 2 .}

There are three important points to stress:

1. Observation of how open group members became. If group members developed a deep trust during previous meetings, they can now "open up and share their needs and weaknesses." 2 Need for affirmation and support in times of shared weaknesses or vulnerable issues. 3

\footnotetext{
$1_{\text {Adams, } 25 .}$

2 Rydberg, 20 .

${ }^{3}$ Ibid., $19-21$.
} 


\section{6}

2. Focus on follow-up and active involvement. Importance of personal contacts and visitations (including absent members ).

3. Four ingredients from the studied passage and discussion on a format of the meeting from this perspective. Nurture. Inductive method.

Meeting 6. Transition Stage. Miraculous Healing. Part 1 .

Points 1-4 are the same as in previous meetings.

5. Ice-breaking activity:

Name one area in your life where you have experienced God's intervention: relationships, relationships with God, illness, marriage relationships, financial difficulties, protection, choosing a career, finding a job, etc. Was it an answer to your or somebody else's prayer?

6. Bible study: Miraculous healing (Acts 3 ).

7. Mission: Reports on conducted visits during the last week. Discovered problems and prayer requests. Planning for future actions. Responsiveness of people in the times of crisis (stress scale). ${ }^{1}$ Importance of active listening. Power of prayers.

${ }^{1}$ Neighbour, The Shepherd's Gidebook, 86, 79-88. 
8. Closing prayer: sharing of answers to prayer in their pairs. Introduction of conversational prayer. ${ }^{1}$ 9. The same as in previous meetings.

Part 2.

There are three important points to stress:

1. Ice-breaking activities should become shorter in comparison to the previous meetings. It can be a trap to share powerful experiences in connection with this activity. However, it is important to do exactly what the task is: name in one word the area, tell in one word whose prayer it was. It can also be helpful to plan with the members a special time for social interaction. Then such experiences can be shared.

2. Importance of continuing evangelistic activities.

3. Second component of small-group meetings: worship. Different kinds of prayers. ${ }^{2}$

$\frac{\text { Meeting 7. Transition/Action Stage. }}{\text { Persecution and Fellowship. }}$

Part 1 .

Points 1-4 are the same as in previous meetings.

5. Ice-breaking activity:

What kind of feelings did you have in times of persecution for your faith? What did you need most of all?

\footnotetext{
1 Adams, 27.

${ }^{2}$ Haml in, 48-56; Galloway, 57-72.
} 
6. Bible study: Persecution and fellowship (Acts 4).

7. Mission: Reports on conducted activities during the last week. Planning for the next week's actions. Setting goals for the group: to reach non-Christian relatives and friends. During the next week, each member writes his or her primary oikos and chooses one target person to work with. Points 8-9 are the same as in the previous meeting.

\section{Part 2.}

There are five important points to stress:

1. Moving to another stage. Group members may be more willing to take some responsibilities. Be open to their suggestions.

2. Ice-breaking activity of increased vulnerability. Importance of acceptance no matter what.

3. Setting specific personal missionary goals.

4. Influence of a home-church setting on communication and relationships.

5. Third component of home-church meetings: fellowship.

\section{Meeting 8. Action Stage.}

Strongholds.

Part 1 .

Points 1-4 are the same as in previous meetings.

5. Ice-breaking activity:

Take two small things from your pocket or purse: the first object would represent your strength, the second one would 
symbolize your weakness or area you would like to improve. Share it with the group. 1

6. Bible study: Sin of Ananias and Sapphira (Acts 5:1-11).

7. Mission: Each member shares his or her target person chosen from the primary oikos and planned strategy. Formation of prayer partners for the next few weeks and the exchange of names of their target people. Reports on conducted visits. Prayer requests.

8. Closing prayer in pairs for target people, and the partner's weaknesses and strengths.

9. The same as in previous meetings.

\section{Part 2 .}

There are four important points to stress:

1. It may happen that this particular ice-breaking activity (or similar types) would demand some additional time if a deep personal problem was shared in a dramatic way or with an address to the group for a solution. Then the group should respond through prayer, touch, or goal setting. Rydberg says that in such cases the group should be empathetic and provide needed support and encouragement. "The group exists to help the individual talk through possible solutions and set goals. The group holds the individual accountable while giving him or her the freedom

\footnotetext{
${ }^{1}$ Clemmons and Hester, 25-27.
} 
to fail."1 Usually at this stage of building community, group members are open for such help. 2

2. Strongholds as presented by Neighbour. 3

3. Prayer support by a prayer partner is very important for successful outreach.

4. Fourth component of home-church meetings: mission (analysis of gradual formation of missionary awareness, and vision and activity in the previous meetings).

\section{Meeting 9. Action Stage. Church Growth amid Trials.}

\section{Part 1 .}

Points $1-4$ are the same as in previous meetings.

5. Ice-breaking activity:

Name one of God's promises that is or was hard for you to trust in.

6. Bible study: Church Growth amid Trials (Acts 5:12-42).

7. Mission: Reports of conducted activities, progress, problems. View on church growth based on geographical home churches. Setting goals: to reach my neighbors. Each member writes a list of non-Adventist neighbors and mark those who will be his or her second target. Points 8-9 are the same as in the previous meeting.

${ }^{1}$ Rydberg, 21 .

2 Ibid.

${ }^{3}$ Neighbour, Shepherd's Guidebook, 40-41. 
Part 2 .

There are four important points to stress:

1. The geographical principle of home churches as a goal for the church with an integrated support system for this ministry.

2. The importance of multiplied goals in mission with one primary target at a time. To set the second target is significant because it creates awareness for opening opportunities and provides a possibility for building a basis for relationships through small favors.

3. Approach to leadership. Different styles of leadership.

4. Hindrances to communication in the group. 1

\section{Meeting 10. Action/Termination Stage. outdoor Meeting.}

Part 1 .

1. Welcome to all group members and visitors.

2. Conversational prayer.

3. Praise through singing.

4. Fellowship: meal and conversation around progress or challenges in the mission activities. Time for testimonies and past experiences.

1 Douglas R. Kilcher, "Starting a Home Bible Fellowship Group for New Church Members: A Manual to Help the Leader," Manual, Wenatchee, WA: n.p., n.d., 10-11. See also, Judy Hamlin, The Small Group Leaders Training Course: A Trainer's Manual (Colorado, CO: NavPress, 1990), 51-69, 112 . 


\section{2}

6. Sports' games (optiona1).

7. Closing hymn and prayer.

Meeting 11. Termination Stage.

Appointment of Seven Helpers.

Part 1 .

Points 1-4 are the same as in meetings 4-9.

5. Ice-breaking activity:

What are the reasons and consequences for burnout of church leaders? Have you had such an experience in your 1 ife?

6. Bible study: Appointment of Seven Assistants (Acts 6:17)

7. Mission: Sharing the progress and challenges of missionary activities. Setting a goal to reach apostatized members in their geographical areas. Those who visited these people before can share their views on reasons for apostasy and present problems of these people. Addresses are distributed.

8. Conversational prayer.

9. The same as in previous meetings.

\section{Part 2.}

There are five important points to stress:

1. Analysis of the former outdoor meeting. Neighbour shows that as there is a need for more fellowship time in the 


\section{3}

beginning, the same need again appears by the tenth meeting. 1

2. Development of assistants, their qualities and responsibilities.

3. The importance of persistent efforts and supportive relationships in reaching apostatized members.

4. Evaluation of the home-church ministry. It is good to have some ways of evaluating every session, seeing what has been effective and what has not. 2

5. Weekly meetings for home-church leaders and reports on the group progress.

Meeting 12. Termination Stage. The story of stephen.

Points 1-4 are the same as in previous meetings.

5. Bible discussion on Acts $6: 8-15 ; 7$ built around one question: What attracts you most in the story of Stephen? 6. Conversational prayer with a focus on mission goals, future ministry, and each other.

7. Fellowship: a meal with the sharing of personal experiences during these twelve weeks of training. 8. Closing hymn and the Lord's prayer.

${ }^{1}$ Neighbour, The Shepherd's Guide Book, 114.

2 Leypoldt, 117; How to Lead Small Group Bible Studies, 56-59; Kilcher, "Starting a Home Bible Fellowship Group for New Church Members," 28. 


\section{APPENDIX 2}

\section{QUESTIONNAIRE}

Answer the questions appropriately or rate on a scale of 1 to 5, with 1 being "very important" and 5 being "not so important" suggested reasons:

\section{Section 1}

1. Why do new members apostatize?

Doctrinal disagrements $\begin{array}{lllll}1 & 2 & 3 & 4 & 5\end{array}$ Not enough information before baptism $\begin{array}{lllll}1 & 2 & 3 & 4 & 5\end{array}$ Loneliness in the church $\begin{array}{lllll}1 & 2 & 3 & 4 & 5\end{array}$

Disappointment-Christianity does not work in my life $123 \quad 4 \quad 5$ Stopped growing spiritually $\begin{array}{lllll}1 & 2 & 3 & 4 & 5\end{array}$

No deep personal relationship with Jesus Christ $\begin{array}{lllll}1 & 2 & 3 & 4 & 5\end{array}$

2. Why do members become missing?

Inadequate number of pastors

$\begin{array}{lllll}1 & 2 & 3 & 4 & 5\end{array}$

Lack of training among pastors

$\begin{array}{lllll}1 & 2 & 3 & 4 & 5\end{array}$

Lack of training among pastors

$\begin{array}{lllll}1 & 2 & 3 & 4 & 5\end{array}$

Infrequent home visitations

$\begin{array}{lllll}1 & 2 & 3 & 4 & 5\end{array}$

Natural results from mass conversions

$\begin{array}{lllll}1 & 2 & 3 & 4 & 5\end{array}$

Lack of personal contacts with new converts

$\begin{array}{lllll}1 & 2 & 3 & 4 & 5\end{array}$ 
Lack of knowledge concerning the new converts' personal problems

$\begin{array}{lllll}1 & 2 & 3 & 4 & 5\end{array}$

Difficulty in finding out when a person stopped attending church

$\begin{array}{lllll}1 & 2 & 3 & 4 & 5\end{array}$

\section{Section 2}

3. Can the house churches (in your opinion) help solve the problem with apostatized and missing members?

4. What are the primary reasons for the breakdown of home churches in the Euro-Asia Division?

Inadequate information of how to start a home-church ministry

$\begin{array}{lllll}1 & 2 & 3 & 4 & 5\end{array}$

Inadequate training of home-church leaders

$\begin{array}{lllll}1 & 2 & 3 & 4 & 5\end{array}$

Lack of developed lessons for home-church meetings

$\begin{array}{lllll}1 & 2 & 3 & 4 & 5\end{array}$

Inadequate involvement of the pastor

$\begin{array}{lllll}1 & 2 & 3 & 4 & 5\end{array}$

Confusion of the purpose for home churches $\begin{array}{lllll}1 & 2 & 3 & 4 & 5\end{array}$

Haphazard meetings with home-church leaders $\begin{array}{llllll}1 & 2 & 3 & 4 & 5\end{array}$

Disunity of the home churches

$\begin{array}{llllll}1 & 2 & 3 & 4 & 5\end{array}$

5. What causes house churches to function well?

6. Do you have house churches in your Conference (Union)?

7. How long have they functioned?

8. What kinds of materials do the house-church leaders use?

9. How often do house-church leaders meet with their supervisors?

10. Have you had visitors from "the world"?

11. What types of problems do you have in your local house church? 
APPENDIX 3

SUMMARY OF DATA FOR THE EURO-ASIA DIVISION, $1985-1995$

\begin{tabular}{|c|c|c|c|c|c|c|c|c|c|c|}
\hline & 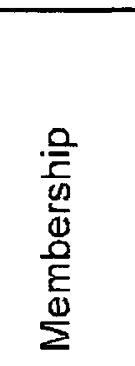 & 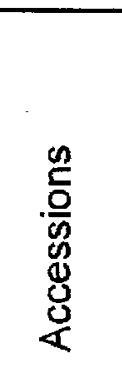 & $\begin{array}{l}\frac{r}{0} \\
\frac{1}{\alpha}\end{array}$ & 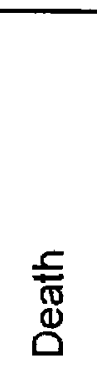 & 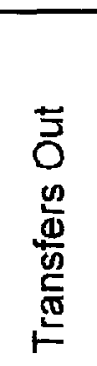 & 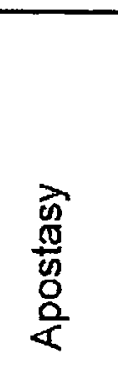 & 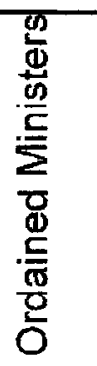 & 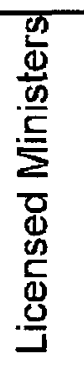 & 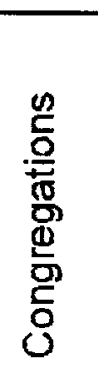 & 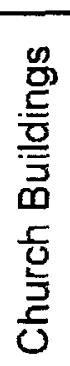 \\
\hline 1985 & 31,305 & 1,718 & 0.98 & $\overline{-}$ & - & 300 & -- & 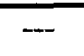 & 414 & -- \\
\hline 1986 & 31,679 & 232 & 1.19 & - & -- & 9 & 188 & 83 & 418 & - \\
\hline 1987 & 32,057 & 1,553 & 1.19 & - & - & 293 & $188+$ & $83+$ & 423 & - \\
\hline 1988 & 32,392 & 1,662 & 1.04 & 860 & 192 & 275 & 203 & 93 & 460 & -- \\
\hline 1989 & 34,146 & 3,179 & 5.41 & 962 & 64 & 399 & 199 & 64 & 498 & - \\
\hline 1990 & 37,388 & 5,030 & 9.5 & 937 & 525 & 326 & 210 & 91 & 546 & 206 \\
\hline 1991 & 46,623 & 11,340 & 24.7 & 1,241 & 402 & 462 & 229 & $91+$ & 601 & 193 \\
\hline 1992 & 71,873 & 28,295 & 54.16 & 1,092 & 839 & 1,114 & 269 & 304 & 738 & 310 \\
\hline 1993 & 95,885 & 28,241 & 33.4 & 1,122 & 1,279 & 1,792 & 267 & 518 & 800 & 480 \\
\hline 1994 & 98,963 & 22,260 & 3.21 & 1,243 & 7,039 & 10,900 & $27 \overline{6}$ & 399 & 883 & 357 \\
\hline 1995 & 109,889 & 21,368 & 11.0 & 1,398 & 880 & 7,977 & 291 & 499 & 1,017 & 473 \\
\hline
\end{tabular}

Source: 123rd Annual Statistical Report 1985, 24-25; 124th Annual Statistical Report 1986, 24-25; 125th Annual Statistical Report 1987, 24-25; 126th Annual Statistical Report--1988, 24-25; 127th Annual Statistical Report--1989, 26-27; 128th Annual statistical Report--1990, 24-25; 129th 
Annual Statistical Report--1991, 12-13; 130th Annual Statistical Report--1992, 12-13; 131st Annual Statistical Report--1993, 12-13; 132nd Annual Statistical Report--1994, 12-13. Data for 1995 are presented on the basis of information supplied by the Euro-Asia Division. 
Adams, Milton. The Beginnings of Reaching out in Love: A Seven Week Introduction for a College or High School Small Group. College Place, CA: Color Press, 1991.

Aeschlimann, Carlos E. "Harvest 90 Exceeds Expectations." Adventist Review, November 22, 1990, 20-22.

Alb, Larry Adam. "Developing a Small Group Ministry for Church Renewal and Growth." D.Min. dissertation, Fuller Theological Seminary, 1986.

Anderson, Philip A. Church Meetings That Matter. Philadelphia: United Church Press, 1965.

Andross, Matilda Erickson. Story of the Advent Message. Washington, DC: Review and Herald Publishing Association, 1926.

Arn, Win, and Charles Arn. The Master's Plan for Making Disciples. Pasadena, CA: Church Growth Press, 1982.

Arnold, Jeffrey. The Big Book on Small Groups. Downers Grove, IL: InterVarsity Press, 1992 .

Barker, Steve, Judy Johnson, Jimmy Long, Rob Malone, and Ron Nicholas. Small Group Leaders' Handbook. Downers Grove, IL: Inter-Varsity Press, 1982.

Barker, Steve, Judy Johnson, Rob Malone, Ron Nicholas, and Doug Whallon. Good Things Come in Small Groups.

Downers Grove, IL: InterVarsity Press, 1985.

Barlow, T. Ed. Small Group Ministry in the Contemporary Church. Independence, MO: Herald Publishing House, 1972 .

Barrett, Lois. Building the House Church. Scottdale, PA: Herald Press, 1986. 
Baumgartner, Erich W. "Developing Leaders on the Frontier." Adventist Frontiers, May 1996, 3, 30-31.

Beeson, Trevor. Discretion and Valour: Religious Conditions in Russia and Eastern Europe. Philadelphia: Fortress Press, 1982 .

Birkey, Del. The House Church. Scottdale, PA: Herald Press, 1988 .

Boettcher, J. T. "Good News from Russia." The Advent Review and Sabbath Herald, December 20, 1923, 9.

Brown, Stanley C., and Robert H. Deits. Folly or Power? Encounter Groups in the Church. New York: Hawthorn Books, W. Clement Stone, Publisher, 1975.

Burton, Shirley. "Report from Perth--II." Adventist Review, November 7, 1991,6 .

Butler, Harold, and Peter Koolik. "Euro-Asia: 500 Churches to Build." Adventist Review, August 5, 1993, 24-25.

Callahan, Kennon L. Twelve Keys to an Effective Church. San Francisco: Harper and Row, Publishers, 1983.

Carter, Sarah Elizabeth. By Jet over Pioneer Footprints. Nashville, TN: Southern Publishing Association, 1967.

Carter, Beverley. "Pentecost Revisited." Adventist Review, November 9, 1995, 21-22.

Cerna, Miguel Angel. The Power of Small Groups in the Church. Newbury Park, CA: El Camino Publishing, 1991. "Win Them and Hold Them." Ministry, December 1993, 24-25.

Chamberlin, Cindy. "Operation Bearhug Reaches Across Pacific." Adventist Review, November 19, 1992, 20-21.

Cho, Paul Yonggi. Successful Home Cell Groups. Plainfield, NJ: Logos International, 1981.

Christian, L. H. "Europe's Call to America." The Advent Review and Sabbath Herald, December 9, 1920,11-16.

"The Russian Tragedy." The Advent Review and Sabbath Herald, October 27, 1921, 24 . 
Clemmons, William, and Harvey Hester. Growth through Groups. Nashville, TN: Broadman Press, 1974.

Coleman, Robert E. The Master Plan of Evangelism. Old Tappan, NJ: Fleming H. Revell Company, 1964.

Conradi, L. R. "A Visit to Russia." In Historical Sketches of the Foreign Missions of the Seventh-day Adventists, 250-271. Basle: Imprimerie Polyglotte, 1886.

"The German-Russian Mission Field." The Advent Review and Sabbath Herald, December 5, 1893, 762 .

- "The German and Russian Fields. " The Advent Review and Sabbath Herald, April 4, 1893, 214.

"The German and Russian Field." The Advent Review and Sabbath Herald, April 11, 1893, 230.

"The Present Outlook in the Russian Mission." The Advent Review and Sabbath Herald, December 6, 1892,757 .

Cosby, N. Gordon. "Inward Journey." In Groups That Work, ed. Walden Howard, 59-62. Grand Rapids, MI: Zondervan Publishing House, 1967.

Cress, James A. "New Members Need." Ministry, December $1993,26$. 1993,24 .

Cross, Patricia K. Adults as Learners. San Francisco: Jossey-Bass, 1981 .

Davis, Creath. Sent to Be Vulnerable. Grand Rapids: Zondervan Publshing House, 1973.

Dean, Rodney J., and Gary L. McIntosh. How to Start or Evaluate a Smal1 Group Ministry. Lynchburg, VA: Church Growth Institute, 1991.

Demidov, M. "An Appeal from Russia." The Advent Review and Sabbath Herald, June 5, 1919, 32 .

Deshler, Byron G. The Power of the Personal Group. Nashville, TN: Tidings, n.d.

Dewees, Curt. "Youth Train Peers to Teach Temperance." Adventist Review, November 26, 1992, 18-20. 
Dibbert, Michael T., and Frank B. Wichern. Growth Groups. Grand Rapids, MI: Zondervan Publishing House, 1985.

Dossman, Craig A., Sr. From House to House. Lincoln, NE: Baby Boomer Ministries Resource Center, 1994.

Edge, Findley B. "Introduction." In William Clemmons and Harvey Hester, Growth through Groups, 13-23.

Nashville, TN: Broadman Press, 1974.

Eims, Leroy. The Lost Art of Disciple Making. Grand Rapids: Zondervan Publishing House, 1978.

Evans, Louis H. Creative Love. Old Tappan, NJ: Fleming H. Revel1 Company, 1977.

Feucht, Oscar E. Everyone a Minister. St. Louis, MO: Concordia Publishing House, 1974.

Finley, Mark. The Cross and the Kremlin. Fallbrook, CA: Hart Research Center, 1992.

- Padded Pews or Open Doors. Boise, ID: Pacific Press, 1988. $1993,16-18$.

Gaede, D. P. "The West Russian Mission." In General Conference Bulletin, 52. Washington, DC: General Conference of Seventh-day Adventists, 1909.

Galloway, Dale E. 20/20 Vision: How to Create a Successful Church with Lay Pastors and Cell Groups. Portland, OR: Scott Publishing Company, 1986.

- Lay Pastor Training Manual for Successful Home Group Meetings. Portland, OR: New Hope Community Church, n.d.

George, Carl F. Prepare Your Church for the Future. Grand Rapids, MI: Fleming H. Revell, 1992 .

- How to Break Growth Barries. Grand Rapids:

Baker, 1993.

George, Carl F., with Warren Bird. The Coming Church Revolution: Empowering Leaders for the Future. Grand Rapids, MI: Fleming H. Revel1, 1994. 
Geyer, Nancy, and Shirley Noll. Team Building in Church Groups. Valley Forge: Judson Press, 1970.

"Godichnij Otchet Secretarya EAD" ("Annual Report of the Secretary of the Euro-Asia Division"). In Reports, 1-3. Moscow: The Euro-Asia Division, 1993.

"Godovoj Otchet ADRA Evropejskogo-Aziatskogo Diviziona" ("Annual Report of ADRA of the Euro-Asia Division"). In Reports, 14-15. Moscow: The Euro-Asia Division, 1995 .

Green, Michael. Evangelism in the Eariy Church. London: Hodder and stoughton, 1970 .

- Evangelism--Now and Then. Leicester, England: InterVarsity Press, 1979.

Griffin, Charles J. "'Domus Ecclesiae': An Examination of House Churches." D. Min. project report, Andrews University, 1987.

Griffin, Em. Getting Together: A Guide for Good Groups. Downers Grove, IL: InterVarsity Press, 1982.

Griffiths, Michael. "Eastern Religions." In How Shall We Reach Them? ed. Michael Green and Alister McGrath, 107-124. Nashville, TN: Thomas Nelson Publishers, 1995 .

Guild, Daniel R. "Adventist Radio Blankets Former Soviet Union." Adventist Review, December 31, 1992, 21-22.

. "Evangelism Schools to Convene in Newest Division. Adventist Review, June 27, 1991, 23.

. "Meetings Triple Membership in St. Petersburg." Adventist Review, March 19, 1992, 19-20.

Hadaway, C. Kirk, Francis M. DuBose, and Stuart A. Wright. Home Cell Groups and House Churches. Nashville, TN: Broadman Press, 1987.

Hadley, G. Gordon. "The Medical Work in Relation to Islam." In The Three Angels and the Crescent, a Reader: Adventist Approaches to Islamic People, ed. Jonquil Hole and Borge Schantz, 197-207. Brackneli, Berkshire: SDA Global Centre for Islamic Studies, 1993. 
Hamlin, Judy. The Small Group Leaders Training Course: Trainer's Manual. Colorado Springs, CO: NavPress, 1990 .

- Welcome to Your First Small Group. Wheaton, IL: Victor Books, 1993.

Harnack, Adolf. The Mission Expansion of Christianity in the First Three Centuries. 2 vols. London: Williams and Norgate, 1908 .

Hegstad, Roland R. "Challenge At." Liberty, March/April, 1991, 9-13.

Heinz, Daniel. "Adventist Celebrate Centennial of Church in Soviet Union." Adventist Review, May 10, 1984, 13-14.

Hestenes, Roberta. Turning Committees into Communities. Colorado Springs, Co: NavPress, 1991. - Using the Bible in Groups. Philadelphia, PA: Westminster Press, 1983.

Hirlinger, J. W. "Conditions in Russia." The Advent Review and Sabath Herald, February 27, 1919, 26.

Howard, Walden. Groups That Work. Grand Rapids, MI: Zondervan Publishing House, 1967.

Howel1, Emma E. The Great Advent Movement. Washington, DC: Review and Herald Publishing Association, 1935.

How to Lead Small Group Bible Studies. Colorado Springs, CO: NavPress, 1983.

Hunter, George G., III. How to Reach Secular People. Nashville, TN: Abingdon Press, 1992.

Hurston, Karen. Growing the World's Largest Church. Springfield, MO: Gospel Publishing House, 1994.

Ising, W. K. "The Work in Russia." Missions Quarterly 1 (1927):17-20.

Ivanova, Natasha. "Four Years without Holidays." Adventist Review, Special Issue, June 1995, 20.

James, Don, and Ruth James. Small Group Awareness \& Leader's Training. Berrien Springs, MI: PMC \& North American Division Evangelism Institute, n.d. 
Johnson, David W., and Frank P. Johnson. Joining Together: Group Theory and Group Skills. Englewood Cliffs, NJ: Prentice Hall, 1975.

Johnson, Kurt. Small Group Outreach. Hagerstown, MD: Review and Herald Publishing Association, 1991.

Johnsson, William G. "The Risen Christ over Red Square." Adventist Review, June 18, 1992, 13-15.

"Snapshots of Russia and the Ukraine." Adventist Review, June 25, 1992, 8-10.

Kangas, Janet Leigh. "Offering Will Provide Institutions for Newest Division." Adventist Review, December 17, $1992,20-21$.

Kilcher, Douglas R. "Starting a Home Bible Fellowship Group for New Church Members: A Manual to Help the Leader." Manual. Wenatchee, WA: n.p., n.d.

"The Minister as an Equipper." In The Adventist Minister, ed. C. Raymond Holmes and Douglas R. Kilcher, 99-108. Berrien Springs, MI: Andrews University Press, 1991 .

Killinger, John: All You Lonely People, All You Lovely People. Waco, TX: Word Books, Publisher, 1973.

Klauck, Hans-Josef. "The House Church as Way of Life." Theology Digest 30 (1982): 153-157.

Knowles, Malcolm. The Adult Learner: A Neglected Species. Houston: Gulf Publishing, 1984.

Kolarz, Walter. Religion in the Soviet Union. New York: St. Martin's Press, 1961.

Kolesnikov, Vladimir. "Kriminalnaya Obstanovka v Rossii Krajne Napryazhennaya" ("Criminal Situation Is Extremely Intensive in Russia") • Ogonek 52 (1995): 2627 .

Kouzes, James M., and Barry Z. Posner. The Leadership Challenge: How to Get Extraordinary. Things Done in Organizations. San Francisco, CA: Jossey-Bass, Publishers, 1987.

Krupp, Nate. God's Simple Plan for His Church--and Your Place in It: A Manual for House Churches. Woodburn, OR: Solid Rock Books, 1993. 


\section{5}

Krushenitzkij, V. "Structurnaya Reorganizatziya Tzerkvi" ("Structural Reorganization of the Church"). Adventistskij Vestnik 1 (1994):8-9.

Kulakov, Mikhail. God's Soviet Miracles. Boise, ID:

Pacific Press Publishing Association, 1993.

Kulakov, M. P. "When KGB Came Calling." Liberty, January/February, 1994, 15-20.

- "Bright Prospects in the U.S.S.R." Adventist Review, JuIy 12, 1990, 22-24.

Lane, Christel. Christian Religion in the Soviet Union. Albany: State University of New York Press, 1978.

Leypoldt, Martha M. 40 ways to Teach in Groups. Valley Forge, PA: Judson Press, 1970.

Lindgren, Alvin J., and Noman Shawchuck. Let My People Go: Empowering Laity for Ministry. Nashville: Abingdon, 1980 .

Loebsack, H. J. "The Gospel of the Second Advent in Eastern Europe, North and Central Asia." The Advent Review and Sabbath Herald, April 18, 1929, 8-9.

Lohne, Alf. "U.S.S.R. Reports Membership Figures." Adventist Review, May 27, 1982, 15 .

Long, Jimmy. "Inductive Bible Study." In Small Group Leaders' Handbook, ed. Steve Barker, 107-117. Downers Grove, IL: InterVarsity Press, 1982 .

. "How to Plan and Lead a Small Group." In Small Group Leaders' Handbook, ed. Steve Barker, 118-129. Downers Grove, IL: Intervarsity Press, 1982.

Mallison, John. Creative Ideas for Small Groups in the Christian Community. Sydney, Australia: Renewal Publications, 1978.

Matzanova, Anna, and Pavel Matzanov. Po Ternistomu Puti (By the Thorny Way). Kaliningrad: Yantarnij Skaz, 1995.

McBride, Neal F. How to Lead Small Groups. Colorado Springs, CO: NavPress, 1990. - How to Build a Small Groups Ministry. Colorado Springs, CO: NavPress, 1995. 
McKenna, David L. Power to Follow, Grace to Lead. Dallas: World Publishing, 1989.

Means, James E. Leadership in Christian Ministry. Grand Rapids, MI : Baker Book House, 1989.

Medley, Carlos. "Breakthrough in the U.S.S.R." Adventist Review, August 7, 1986, 6-8.

Meier, Paul D., Frank B. Minirth, Frank B. Wichern, and Donald E. Ratcliff. Introduction to Psychology and Counseling. Grand Rapids: Baker Book House, 1991.

Miller, Keith. A Second Touch. Waco, TX: Word Books, 1967.

Miller, William. A Christian's Response to Islam. Nutley, NJ: Presbyterian and Reformed Publishing Co., 1976.

Milson, Fred. Small Groups for Christians. London: Methodist Church Division of Education and Youth, 1982 .

Moyer, Bruce $\mathrm{C}$. "The Challenge of the Cities." Ministry, November $1992,23-26$.

Mueller, Konrad. "Redeeming the Past." Adventist Review, March 30, 1995, 18-19.

Neighbour, Ralph W., Jr. The Shepherd's Guidebook. Houston, TX: Touch Publications, 1992.

. "The Urbanization of the Earth." In Future Church, ed. Ralph W. Neighbour, Jr., 9-17. Nashville, TN: Broadman Press, 1980.

Neighbour, Ralph W., Jr., with Lorna Jenkins. Where Do We Go from Here? A Guidebook for the Cell Group Church. Houston, TX: Touch Publications, 1990.

"The Urbanization of the Earth." In Future Church, ed. Ralph W. Neighbour, Jr., 9-17. Nashville, TN: Broadman Press, 1980.

Newman, David J., and Sharon Cress. "Super Evangelism in Moscow." Ministry, November 1993, 15-19.

"Newsbreak: ADRA Prepares to Ship Food to Former Soviet Republics." Adventist Review, February 20, 1992, 6.

"Newsbreak: Belarus Meeting Brings 250 Baptisms." Adventist Review, April 1995, 7 . 
"Newsbreak: Evangelism Blossoms in the Soviet Union." Adventist Review, August 15, 1991, 6 .

"Newsbraek: Euro-Asia Carries on Amid Historic Changes." Adventist Review, January 23, 1992, 6 .

"Newsbreak: Euro-Asia Update." Adventist Review, December $17,1992,7$.

"Newsbreak: First Adventist Journal Printed in Russia." Adventist Review, December 17, 1992, 7.

"Newsbreak: Kremlin Evangelistic Series Brings Major Harvest." Adventist Review, May 28, 1992, 6-7.

"Newsbreak: Lay Evangelism Brings New Baptisms in Ukraine." Adventist Review, August 17, 1995, 6.

"Newsbreak: New Bibles Distributed in Russia." Adventist Review, March 23, 1995, 6.

"Newsbreak: Russian Members' Witness Leads to 1,100 Baptisms." Adventist Review, January 25, 1996, 7.

"Newsbreak: Russian Outreach Series Brings 2,520 Baptisms." Adventist Review, July 30, 1992, 6 .

"Newsbreak: Ukrainian Update." Adventist Review, August 31 , 1995,6 .

"Newsbreak: Ukrainian Update." Adventist Review, September $14,1995,6$.

"Newsbreak: Volunteers Hold Training Sessions in Eastern Europe." Adventist Review, June 22, 1995, 7 .

Nicholas, Ron. "A Strategy for Small Groups in Your Church." In Good Things Come in Small Groups, ed. Steve Barker, 121-132. Downers Grove, IL: InterVarsity Press, 1985.

- "The Basics of Small Group Life." In Small Group Leaders' Handbook, ed. Steve Barker, 34-47. Downers Grove, IL: InterVarsity Press, 1982 .

"The Four Ingregients of Good Group Life." In Good Things Come in Small Groups, ed. Steve Barker, 2237. Downers Grove, IL: InterVarsity Press, 1985. 
Olsen, M. E1lsworth. Origin and Progress of Seventh-day Adventists. Washington, DC: Review and Herald Publishing Association, 1925.

122nd-125th Annual Statistical Report. Washington, DC: General Conference of Seventh-day Adventists, 19851988 .

126th-132nd Annual Statistical Report. Silver Spring, MD: General Conference of Seventh-day Adventists, 19891995.

Oosterwal, Gottfried. "Patterns of SDA Church Growth in North America." Research Report No. 1, Department of World Mission, Andrews University, 1974.

. "The Process of Secularization." In Meeting the Secular Mind: Some Adventist Perspectives, ed. Humberto M. Rasi and Fritz Guy, 42-62. Berrien Springs, MI: Andrews University Press, 1985.

"Otchet Otdela Subbotnej Shkoli I Ryadovikh Missionerov" ("Report of Sabbath School and Lay Missionaries' Department"). In Reports, 16-17. Moscow: The EuroAsia Division, 1995.

"Otchet Secretarya" ("Report of the Secretary"). In Reports, 1-13. Moscow: The Euro-Asia Division, 1995.

"Otchet Secretarya EAO" ("Report of the Secretary of the Euro-Asia Division"). In Reports, 15-16. Moscow: The Euro-Asia Division, 1994.

Otis, George, Jr. The Last of the Giants. Grand Rapids, MI: Chosen Books, 1991.

Otis, Rose. "Adventist Church Dedicates First Seminary in U.S.S.R." Adventist Review, February 16, 1989, 6-7.

"GC President Addresses Largest Gathering of Ukrainian Adventists." Adventist Review, April 26, $1990,20-21$.

"Interview with Elder Neal Wilson and Elder Mikhail Kulakov." Is There Faith in God in Russia? 1 (1987):4-9.

Shipment" "Sabbath Schools, Radio Studio Benefit from 
Paulien, Jon. Present Truth in the Real World. Boise, ID: Pacific Press, 1993.

Peace, Richard. Small Group Evangelism: A Training Program for Reaching Out with the Gospel. Downers Grove, IL: InterVarsity Press, 1985.

Pell, Patty. "The Growing Leader." In Small Group Leaders' Handbook: The Next Generation, ed. Jimmy Long, 161-176. Downers Grove, IL: InterVarsity Press, 1995.

Perk, G. "A Recital of Russian Experiences." In General Conference Bulletin, 52-54. General Conference of Seventh-day Adventists, 1909.

Plueddemann, Jim, and Carol Plueddemann. Pilgrims in Progress: Growing through Groups. Wheaton, IL: Harold Shaw Publishers, 1990.

Pospielovsky, Dimitry. The Russian Church under the Soviet Regime 1917-1982. Crestwood, NY: St. Vladimir's Seminary Press, 1984.

Reid, Clyde. Groups Alive--Church Alive. New York: Harper \& Row, Publishers, 1969.

Reimer, Johannes. Operation Soviet Union: How to Pray for the 160 People Groups in the USSR. Fresno, CA: Logos, 1988 .

Religion in the U.S.S.R. Edited by Robert Conquest. New York: Frederick A. Praeger, 1968.

Richards, Lawrence 0.69 ways to Start a Study Group and Keep It Growing. Grand Rapids: Zondervan Publishing House, 1974 .

Riley, William. The Bible Group: An Owner's Manual. Dublin, Ireland: Mount Salus Press, 1983.

"Rossijskaya Politika: Opros VTzIOM" ("Russian Policy: Survey by Center of Studies of Public Opinion"). Ogonek 49 (1995):17.

Ryan, Michael, and Shephen Chavez. "Intentional Outreach." Adventist Review, June 1995, 10-11.

Rydberg, Denny, with Robin Dursch and Ken Beebe. Building Community in Youth Groups. Loveland, CO: Group Books, 1985 . 
Sahlin, Monte. Sharing Our Faith with Friends without Losing Either. Washington, DC: Review and Herald Publishing Association, 1990.

"Ministering to Singles and Families." Adventist Review, February 3, 1994, 25-27.

Samaan, Philip G. Christ's way of Reaching People. Hagerstown, MD: Review and Herald Publishing Association, 1990 .

Schaller, Lyle E. Assimilating New Members. Nashville, TN: Abingdon Press, 1978.

Schantz, Borge. Your Muslim Neighbour and You: A Manual for Personal Evangelism. Bracknel1, Berkshire: Seventh-day Adventist Global Centre for Islamic Studies, 1993.

Schilt, W. Clarence. Dynamic Small Groups. Hagerstown, MD: Review and Herald Publishing Association, 1992.

Schwanz, Floyd L. Growing Small Groups. Kansas City, MO: Beacon Hill press of Kansas City, 1995.

"Session Actions: Union of Soviet Socialist Republics Division of the General Conference of Seventh-day Adventists." Adventist Review, July 9, 1990, 10.

Seventh-day Adventist Yearbook. Hagerstown, MD: Review and Herald Publishing Association, 1952-1981, 1991-1996.

Skinner, Michael. House Groups. London: Epworth Press \& SPCK, 1969.

"Sluzhenie Zhenschin" ("Women's Ministries"). In Reports, 32-33. Moscow: The Euro-Asia Division, 1995.

Spalding, Arthur Whitefield. Origin and History of Seventhday Adventists. Washington, DC: Review and Herald Publishing Association, 1962 .

Spangler, J. R. "The Soviet Union: A Decade of Destiny." Adventist Review, February 7, 1991, 8-10. $1993,6-7$.

Spicer, William A. Our Story of Missions for Colleges and Academies. Mountain View, CA: Pacific Press Publishing Association, 1921 . 
"Statistical Report Prepared by the Office of Archives and Statistics for the Annual Council of the General

Conference Committee, Bangalore, India, October 5-11, 1993." In Reports, 2-4. Moscow: The Euro-Asia Division, 1993.

Steinbron, Melvin J. Can the Pastor Do It Alone? Ventura, CA: Regal Books, 1987.

Stele, Galina I. "New Testament Home Churches as a Solution to Some of the Main Challenges in the Euro-Asia Division." M.A. thesis, Andrews University, 1993.

Stutzman, Ervin R. Welcome! A Biblical and Practical Guide to Receiving New Members. Scottdale, PA: Herald Press, 1990 .

Stutzman, Ervin R, and David W. Shenk. Creating Communities of the Kingdom. Scottdale, PA: Herald Press, 1988.

Successful Churches: What They Have in Common. Glendale, CA: The Barna Research Group, 1990.

Taylor, Charles R. "Making up for Lost Time." Adventist Review, December 22, 1994, 18-20. $8-9$. "Measuring a Dream." Adventist Review, June 1995,

Teppone, V. V. Iz Istorii Tzerkvi (From History of the Church). Kaliningrad: Yantarnij Skaz, 1993.

Thiel, Nina. "Building Relationships: Community." In Small Group Leaders' Handbook: The Next Generation, ed. Jimmy Long, 39-52. Downers Grove, IL: Intervarsity Press, 1995 .

Thomsen, Marilyn. "The Gospel Opens Doors of an Isolated City." Adventist Review, August 20, 1992, 6-7.

Turner, Nathan W. Effective Leadership in Small Groups. Valley Forge, PA: Judson Press, 1977.

Veerman, David R. Small Group Ministry with Youth. Wheaton, IL: Victor Books, 1992 .

Wagner, C. Peter. Strategies for Church Growth. Ventura, CA: Regal Books, 1987.

Way, Ritchil. "Home Group Ministry Helps Your Church Grow." Ministry, February, 1992, 10-12. 
Weems, Lovett H., Jr. Church Leadership. Nashville, TN: Abingdon Press, 1993.

Wegmeyer, Norman E. The Art of Christian Relationships. Minneapolis, MN: Augsburg Publishing House, 1967.

Whallon, Doug. "Leadership--The Critical Factor." In Good Things Come in Small Groups, ed. Steve Barker, 38-49. Downers Grove, IL: InterVarsity Press, 1985.

White, Ellen G. Gospel Workers. Boise, ID: Pacific Press Publishing Association, 1948.

Testimonies for the Church. 9 vols.

Washington, DC: Review and Herald Publishing Association, 1909 .

. The Ministry of Healing. Mountain View, CA:

Pacific Press Publishing Association, 1942.

Williams, Dan. Seven Myths about Small Groups. Downers Grove, IL: InterVarsity Press, 1991.

Wilson, Marlene. How to Mobilize Church Volunteers. Minneapolis, MN: Augsburg Publishing House, 1983.

Wilson, Ted N. C. "God's Miraculous Power in the Euro-Asia Division." Adventist Review, July 7, 1995, 5-7.

. "Presidents' World Report." Adventist Review, Special Issue, June 1995, 18.

Wolf, Thomas A. "Oikos Evangelism: Key to the Future." In Future Church, ed. Ralph W. Neighbour, Jr., 153-176. Nashville, TN: Broadman Press, 1980.

World Christian Encyclopedia. 1982 ed. S.v. "USSR."

"World Church News: Russian Bible School Graduates More Than 18,000 in First Five Years." Lake Union Herald, January 1996, 21.

"World Report: Actions of General Interest from the 1989 Annual Council--1. Adventist Review, January 11, 1990, 20-23.

"World Report: Mission Outreach Spurs Local Church Growth." Adventist Review, November 12, 1992, 21. 
283

"World Report: Thousands Hear of God's Love." Adventist Review, July 14, 1994, 19-20.

Wright, Eric. Tell the World: Apostolic Patterns for Evangelism Missions. Welwyn, Hertfordshire:

Evangelical Press, 1981.

Year Book of the Seventh-day Adventist Denomination.

Washington, DC: Review and Herald Publishing Association, 1906, 1908, 1924.

Zachary, James H. "I Felt God's Power in Rostov." Adventist Review, October 3, 1991, 8-10.

Zavadskij V. M. "Rabota s Evreyami" ("Work with Jews"). In Reports, 31. Moscow: The Euro-Asia Division, 1995. 
VITA

\section{Personal}

Name: Galina I. Stele

Date of Birth: September 24, 1964

Place of Birth: Kamchatka, U.S.S.R.

Parents: Elijah I. and Lubov G. Velgosha

Date of Marriage: December 31, 1986

Family: husband Artur A. Stele and son Alexander

\section{Educational}

Undergraduate and Graduate Schools Attended:

1981-1985: Pedagogical University, Alma-Ata, U.S.S.R.

1991-1996: Andrews University

Degrees Awarded:

Bachelor of Arts in Education (equivalency), 1985

Master of Arts in Religion, 1993

Master of Divinity (equivalency), 1994

Doctor of Ministry, 1996

\section{Professional}

Professional Experience:

1984-1986: Register, Correspondent Bible School of SDA，U.S.S.R.

1988- Teacher, Zaokski Theological Seminary of SDA, Russia 